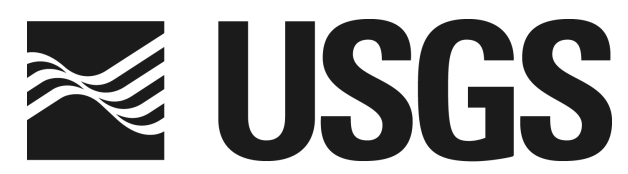

science for a changing world

WASHINGTON STATE

$\mathbf{E} \mathbf{C}^{\mathbf{0}} \mathbf{L}^{\mathbf{0}} \mathbf{G}$

\title{
Southwest Washington Coastal Erosion Workshop Report 1999
}

Guy Gelfenbaum and George M. Kaminsky (Editors)

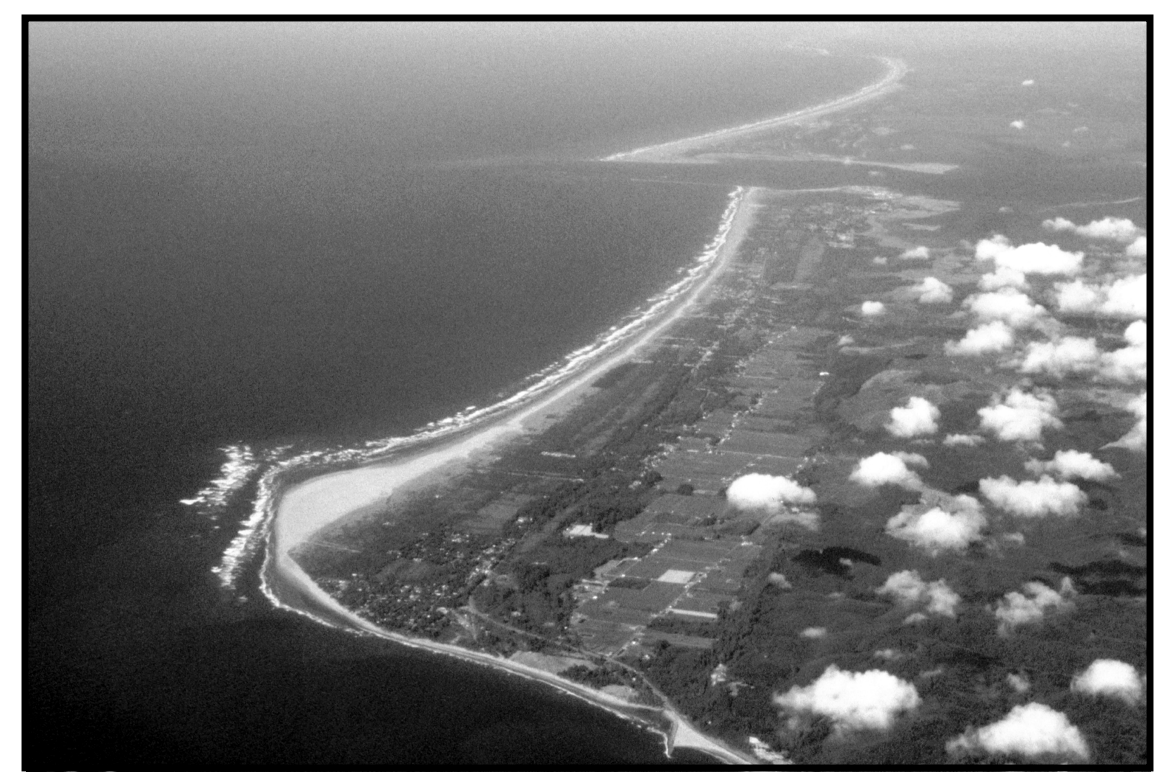

Open-File Report 00-439

October 2000

Prepared in Cooperation with

Washington State Department of Ecology

U.S. Department of the Interior

U.S. Geological Survey 



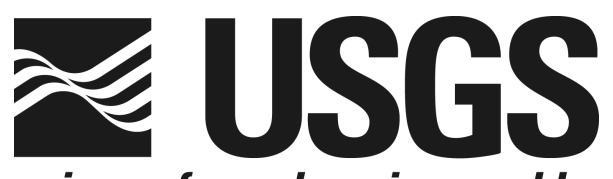

science for a changing world

WASHINGTON STATE

DEPARTMENT OF

E $\quad$ C 0 O

\title{
Southwest Washington Coastal Erosion Workshop Report 1999
}

\section{Editors}

Guy Gelfenbaum ${ }^{1}$ and George M. Kaminsky ${ }^{2}$

\author{
Open-File Report 00-439
}

\section{October 2000}

\section{Prepared in Cooperation with Washington State Department of Ecology}

This report is preliminary and has not been reviewed for conformity with the U.S. Geological Survey editorial standards or with the North American Stratigraphic code. Any use of trade, firm, or product names is for descriptive purposes only and does not imply endorsement by the U.S. Government.

U.S. Department of the Interior U.S. Geological Survey

\footnotetext{
${ }^{1}$ U.S. Geological Survey, Menlo Park, CA

${ }^{2}$ Washington State Department of Ecology, Olympia, WA
} 
Cover Photograph: Aerial photograph of the southwest Washington coast taken in September 1999 showing the offset of the coastline between the Grayland Plains and North Beach sub-cells (looking North). 


\section{TABLE OF CONTENTS}

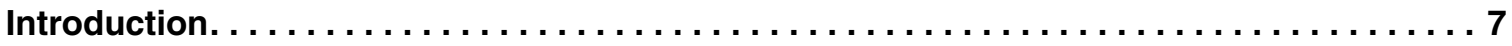

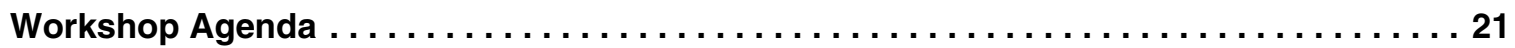

Integrating Shelf and Coastal Stratigraphy to Derive a Holocene Record of Coastal

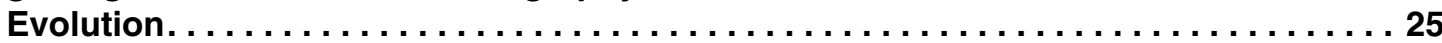

Dave C. Twichell, U.S. Geological Survey

VeeAnn A. Cross, U.S. Geological Survey

April Herb, Portland State University

Sandy Vanderburgh, University College of the Fraser Valley

Curt D. Peterson, Portland State University

Jim B. Phipps, Grays Harbor College

Sedimentation Rates and Occurrences of Tephra in Cores from the Southwest

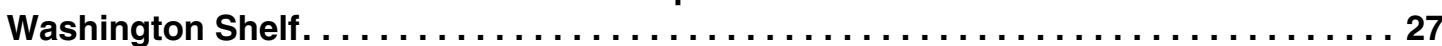

R. Lawrence Phillips, U.S. Geological Survey

Gita Dunhill, U.S. Geological Survey

Preliminary Holocene Beach Sediment Volume Calculations $\ldots \ldots \ldots \ldots \ldots \ldots \ldots \ldots 31$

April A. Herb, Portland State University

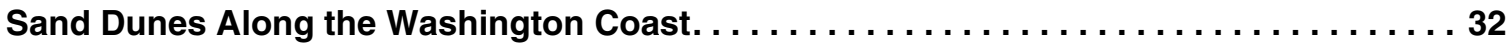

Jim Phipps, Grays Harbor College

Dune Ridge Correlation Between the Clatsop Plains and the Northern Sub-Cells of the Columbia River Littoral Cell: Late-Holocene Paleo-Shoreline Reconstruction of Southwest Washington and Northwest Oregon, USA . . . . . . . . . . . . 33

Curt Peterson, Portland State University

Frank Reckendorf, Reckendorf and Associates

James Phipps, Grays Harbor College

Dave Percy, Portland State University

Sandy Vanderburgh, University College of Fraser Valley

Lorraine Woxell, Portland State University

Harry Jol, University of Wisconsin -Eau Claire

Modeling Shoreface and Barrier Response to Subsidence Events.

Peter Cowell, Coastal Studies Unit, Institute of Marine Science, University of Sydney

History of Sand Sequestering in a Holocene Bay-Margin Spit Complex, Willapa Bay,

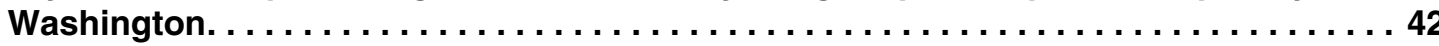

Robert Morton, U.S. Geological Survey

Curt Peterson, Portland State University

Oscar Sorenson, Portland State University

David Qualman, Portland State University

Sandy Vanderburgh, University College of the Fraser Valley 
Preliminary Results and Interpretations of the Late-Holocene Sediment Fill of Willapa Bay and Grays Harbor, Washington . . . . . . . . . . . . . . . . . 45

Sandy Vanderburgh, University College of the Fraser Valley

Curt Peterson, Portland State University

Robert Morton, U.S. Geological Survey

Jim Phipps, Grays Harbor College

David Qualman, Portland State University

Oscar Sorsenson, Portland State University

Presenting Geologic Data in a Web-Based GIS $\ldots \ldots \ldots \ldots \ldots \ldots \ldots \ldots \ldots \ldots \ldots \ldots \ldots \ldots \ldots \ldots \ldots$

David Percy, Portland State University

Morphostratigraphic and Chronologic Similarities of Late Holocene Deposition on Three US Coasts, Resolving Tectonic, Eustatic, and Climatic Influences . . . . . . 49

Robert A. Morton, U.S. Geological Survey

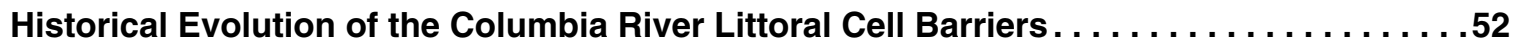
George Kaminsky, Washington Department of Ecology

Interpretation of the Average High Water Line from Aerial Photography: Variability

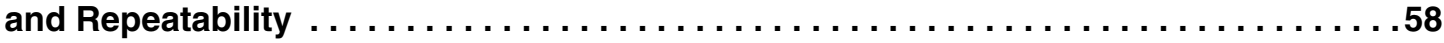

Richard C. Daniels, Washington Department of Ecology

Peter Ruggiero, Washington Department of Ecology

Diana McCandless, Washington Department of Ecology

Bathymetric Volume Change: Data and Analysis $\ldots \ldots \ldots \ldots \ldots \ldots \ldots \ldots \ldots \ldots$

Ann Gibbs, U.S. Geological Survey

Preliminary Results of a Multibeam Bathymetry and Backscatter Survey $\ldots \ldots \ldots \ldots \ldots 81$

Roger D. Flood, Marine Sciences Research Center, SUNY Stony Brook

Vicki Lynn Ferrini, Marine Sciences Research Center, SUNY Stony Brook

Liviu Giosan, Marine Sciences Research Center, SUNY Stony Brook

Laurie Zaleski, Marine Sciences Research Center, SUNY Stony Brook

The Inner Shelf: Source or Sink for Beach Sand? . . . . . . . . . . . . . . . . . .

Dave C. Twichell, U.S. Geological Survey

VeeAnn A. Cross, U.S. Geological Survey

Kenneth F. Parolski, U.S. Geological Survey

Role of Tidal Deltas in the Sediment Budget $\ldots \ldots \ldots \ldots \ldots \ldots \ldots \ldots \ldots \ldots \ldots \ldots$

Christopher R. Sherwood, U.S. Geological Survey

Maarten Buijsman, Washington Department of Ecology

Ann Gibbs, U.S. Geological Survey

High Resolution Ground Penetrating Radar Imaging of Late Prehistoric and

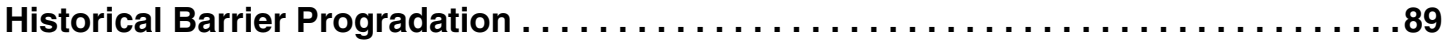

Harry M. Jol, University of Wisconsin -Eau Claire

Brian Junck, University of Wisconsin -Eau Claire

George Kaminsky, Washington Department of Ecology

Diana McCandless, Washington Department of Ecology 
Shoreline Change Modeling - In Relation to the Sediment Budget . . . . . . . . . . 92 Maarten Buijsman, Washington Department of Ecology

Climate Change and Variability: Considering Impacts on Coastal Morphology in the Columbia River Littoral Cell . . . . . . . . . . . . . . . . . . . . . 95 Laura Moore, Woods Hole Oceanographic Institution

Climate Effects on Columbia River Sediment Transport . . . . . . . . . . . . . . . 97 David A. Jay, Oregon Graduate Institute Pradeep Naik, Oregon Graduate Institute

Status of Corps' Projects: Southwest Washington Coast 1999-2000 . . . . . . . . . . 107 Eric Nelson, U.S. Army Corps of Engineers

Shoreline Change Near Grays Harbor Entrance and South Jetty Testing Update. . . . . 108 David Simpson, Pacific International Engineering

Process Based Tidal and Estuarine Inlet Modeling $\ldots \ldots \ldots \ldots \ldots \ldots \ldots \ldots \ldots \ldots 111$ Marcel Stive, Delft Hydraulics

SWAN Wave Model Sensitivity to Variation in Model Formulation . . . . . . . . . . 112 Meg Palmsten, University of South Florida

Preliminary SWAN Modeling Based on Climatological Data $\ldots \ldots \ldots \ldots \ldots \ldots \ldots \ldots$ Kurt Hanson, U.S. Geological Survey

Grays Harbor Wave Refraction Experiment. . . . . . . . . . . . . . . . . 114

Guy Gelfenbaum, U.S. Geological Survey Chris Sherwood, U.S. Geological Survey Kurt Hanson, U.S. Geological Survey Peter Howd, University of South Florida Meg Palmsten, University of South Florida

Data Collection for Establishing Numerical Models of Grays Harbor, Washington . . . 120 Mary A. Cialone, U.S. Army Engineer Research and Development Center, Coastal and Hydraulics Laboratory

Nicholas C. Kraus, U.S. Army Engineer Research and Development Center, Coastal and Hydraulics Laboratory

Eric Nelson, U.S. Army Engineer District Alex Sumeri, U.S. Army Engineer District Robert Parry, U.S. Army Engineer District David B. Hericks, Pacific International Engineering William G. Grosskopf, Offshore \& Coastal Technologies, Inc.-East Coast Keith Kurrus, Evans-Hamilton Inc.

U.S. Army Corps of Engineers Activities at the Mouth of the Columbia River Rod Moritz, U.S. Army Corps of Engineers 
Columbia River Mouth Dredged Material Disposal - Coastal Communities Plans . . . . . 128 Vladimir Shepsis, Pacific International Engineering

Scales of Morphologic Variability from Event Response to Interannual Change . . . . . 132

Peter Ruggiero, Washington Department of Ecology George Kaminsky, Washington Department of Ecology

Columbia River Littoral Cell Sediment Budget: What Can We Say about the Source? . . 141

Guy Gelfenbaum, U. S. Geological Survey

Christopher Sherwood, U. S. Geological Survey

David Twichell, U. S. Geological Survey

Ann Gibbs, U. S. Geological Survey

Curt D. Peterson, Portland State University

Maarten Buijsman, Washington Department of Ecology

George Kaminsky, Washington Department of Ecology

Peter Ruggiero, Washington Department of Ecology

Evaluating Coastal Susceptibility, Working Toward A Decision Support System . . . . . 149

Brian Voigt, Washington Department of Ecology

Peter Ruggiero, Washington Department of Ecology

George Kaminsky, Washington Department of Ecology

Sediment Size Distribution within the Columbia River Littoral Cell .

Emily Lindstrum, Washington Department of Ecology

Peter Ruggiero, Washington Department of Ecology

Jerry Franklin, Washington Department of Ecology

Dave Twichell, U.S. Geological Survey

George Kaminsky, Washington Department of Ecology

Medium- Large-Scale Nearshore Morphologic Variability along the Columbia River

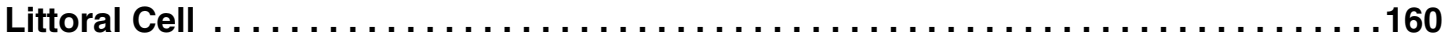

Peter Ruggiero, Washington Department of Ecology

Guy Gelfenbaum, U.S. Geological Survey

Jamie MacMahan, University of Florida

George Kaminsky, Washington Department of Ecology

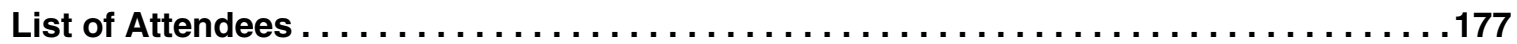

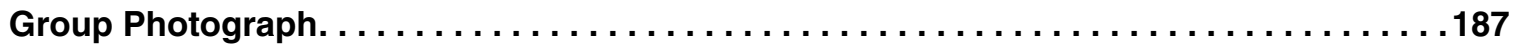




\section{INTRODUCTION}

This report is a compilation of abstracts that correspond to oral presentations and posters presented at the fourth principal investigators workshop of the Southwest Washington Coastal Erosion Study. The workshop was held November $17-20,1999$ at the Department of Ecology headquarters building in Olympia, WA. For the third consecutive year in November, the workshop convened the entire multi-disciplinary group of scientists and engineers working on the study or on related projects within the Columbia River littoral cell (CRLC). The workshop participants are listed in the List of Attendees section towards the end of this report.

The purpose of this workshop was to bring all study investigators and associated engineers and scientists together to discuss recent work, ongoing tasks, and future research plans in the CRLC. Investigators were asked to present recent data, preliminary interpretations, and research results to invoke discussion and correlation with parallel scientific efforts. The abstracts compiled in this report represent work in progress, and the reader is advised that the information provided herein is preliminary and subject to change.

The workshop presentations were generally arranged from large-scale processes to smallscale processes. The initial talks discussed results of study tasks that document the geological framework and the evolution of the coast over the past several thousand years. These studies provide the basis for understanding how the inherited substrate and shelf configuration influence the way the coast responds to changes due to other factors such as sediment budget, sea level, and regional tectonics. The next set of presentations discussed research results related to the historical coastal evolution of the CRLC. These talks reviewed work that has quantified century-scale changes in coastal barrier volumes, shoreline position, sea floor elevation, ebb-tidal delta morphology, and sediment distribution patterns, including human-induced changes since the late 1800s. A few talks also reviewed the potential influences of climate change trends and fluctuations on regional shoreline change, especially as related to Columbia River sediment supply and events such as El Niño. Finally, a group of talks focused on contemporary projects and processes that affect the morphologic character of the coast on a seasonal to interannual scale. These presentations included a review of recent and ongoing coastal engineering projects at the entrances to Grays Harbor, Willapa Bay, and the Columbia River. In addition to construction and dredging activities, a number of presentations on data collection and modeling efforts, process studies, and monitoring programs provided insights to the particular sensitivities of the coast to driving terms such as wave direction, tidal currents, antecedent beach topography and nearshore bar geometry.

During the final day of the workshop, the presentations addressed more integrated topics, including the sediment budget, data sharing and documentation, and the development of decision-support products for coastal managers. Presentations by Dr. Robert Morton of the U.S. Geological Survey and Dr. Marcel Stive of Delft Hydraulics and Delft University of Technology, offered independent evaluations of the progress of the study. The

workshop concluded with a group discussion regarding the present state of understanding 
of the coast, including fundamental questions to resolve, and possible tasks to prioritize for future research.

\section{BACKGROUND}

The Southwest Washington Coastal Erosion Study was initially conceived in 1994 by the recognition of a lack of basic understanding of coastal processes and shoreline changes along the southwest Washington coast. The study began in the spring of 1996 and is now in the fourth year of a five-year plan. The study is a multi-disciplinary investigation of the $165-\mathrm{km}$ long coastal region between Tillamook Head, Oregon and Point Grenville, Washington, that is referred to as the CRLC (Figure 1). The study is jointly sponsored and directed by the U.S. Geological Survey, Coastal and Marine Geology Program and the Washington Department of Ecology, Coastal Monitoring \& Analysis Program, with active participation by local communities. Kaminsky and Gelfenbaum (1999) provide details about the development of this federal-state-local partnership. Gelfenbaum et al. (1997) is a report of the first workshop and provides an inventory of the state of the knowledge at the beginning of the study. An overview of the study elements and initial results is provided in Kaminsky et al. (1997). No reports were published for the principal investigators workshop held in November 1997 or the public workshop held in March 1998. The abstracts of the 1998 principal investigators workshop are compiled in Gelfenbaum and Kaminsky (1999).

The study has three principal goals:

1) understand regional sediment system dynamics;

2) determine natural and anthropogenic influences on the littoral system; and

3) predict coastal behaviour at management scales (i.e., decades and tens of kilometers).

These goals are pursued through a wide range of investigations into the geology and coastal processes that span over four orders of magnitude in time and space (days to millennia and meters to hundreds of kilometers). The study approach is to apply a hierarchical systems perspective that considers coastal morphodynamics at the scale of interest in context with the morphodynamics at both smaller and larger scales. At the smaller scale are the important process-drivers of aggregated-scale coastal change, and at the larger scale are the boundary conditions that impose constraints on the morphodynamics at smaller scale.

The array of multi-scale and multi-disciplinary tasks of the study can be grouped into the following five categories:

1) Coastal Change: these tasks involve the analyses of past and present changes in geomorphic features that include barrier evolution, shoreline behaviour, beach morphology monitoring, and bathymetric change. These efforts involve mapping the evolution of the littoral cell over a continuum of scales in order to understand the system 
functioning. The observed coastal changes are being related to environmental forcing, climatological events, sediment budgets, and other influences, including human intervention and tectonic activity.

2) Sediment Budget: this research characterizes and quantifies the sources, pathways and sinks of sediment within the littoral cell. Research is conducted to determine the volumes, accumulation rates, and transport rates of sediment for each of the major environments of the CRLC, including the Columbia River, Willapa Bay, Grays Harbor, the beaches and dunes, and nearshore and shelf sand bodies. This information is critical for determining the sand supply available for shoreline change.

3) Coastal Processes: these tasks include measuring, monitoring, and/or modeling currents, waves, sea level, sediment transport and other climatic conditions that drive coastal responses over a wide range of spatial and temporal scales. The study also uses historical data, hindcast data, and interpretations of morphologic expression to infer process-response relationships.

4) Predictive Modeling: modeling efforts are based on integrated input data sets derived from the analysis of coastal change, sediment budgets, coastal processes, and other environmental forcing conditions and geological constraints. The initial tasks help clarify important geologic and oceanographic processes that govern the coastal changes and refine the conceptual and mathematical models used to make quantitative predictions. Modeling efforts include shoaling and refraction of waves as they propagate from deep to shallow water, inner shelf and surf zone sediment transport due to storms, changing shoreline position, and shoreface change due to episodic coastal subsidence events.

5) Management Support: these tasks involve the development of information and products of direct value to coastal management and the land-use planning efforts of local communities. In addition to basic products such as maps and reports, this work includes susceptibility analyses, development of geographic informations system (GIS)based decision support systems, databases and the application of research results to case studies.

The study approach and research topics described above were developed in recognition of the need to predict shoreline change at a temporal scale relevant to developing viable longterm management alternatives. Because quantitatively accurate prediction of coastal change is inherently difficult at any scale, the study tasks are directed toward obtaining the most fundamental information needed to develop a sufficient understanding of the natural and human-induced complexity of the littoral system so that a predictive capability may be developed.

\section{SCIENTIFIC FINDINGS}

Below is a short synopsis of important preliminary findings and progress of the study as of the 1999 workshop. 
- The study is actively integrating geologic data sets from the shelf, bays, and barriers to reconstruct the Holocene evolution of the coastal system. Dated material from cores and the occurrence of tephra (volcanic glass) layers are enabling the calculation of sedimentation rates and the development of a time history of sediment accumulation along the mid-shelf and within the littoral cell.

- Dune ridges are common features along the coastal plains of all four CRLC subcells. The study has correlated the dune ridges along each sub-cell and across the sub-cell boundaries. The locations of dune ridges are being interpreted to correspond to prehistoric shoreline positions. Tentatively, shoreline positions from $4.0,2.5,1.7,1.2$, and 0.3 thousand years ago have been identified. These times correspond to co-seismic subsidence events associated with Cascadia Subduction Zone earthquakes and they allow for the calculation of shoreline change rates prior to human intervention.

- Simulations of the shoreface and shoreline response to subsidence events are being conducted using a geometrical-based coastal evolution model. Preliminary simulations for Long Beach Peninsula suggest significant shoreline retreat (erosion) associated with a subsidence event similar to those documented to have occurred over the last few thousand years on the Washington coast. Initial model results suggest shoreline recession varying from 100-900 m depending on whether or not the inner shelf is considered as a source of sand to the beaches.

- Grays Harbor and Willapa Bay are predominately filled with sediment that originated from the Columbia River. Are the bays still filling with sediment from the coast or has the filling ceased? Whether the bays are either sinks or sources of sediment to the coast is important to the sediment budgets and thus to shoreline change predictions. Bay sediments are being examined to assess their late Holocene to historical sedimentation history.

- The historical evolution of the CRLC barriers is now well documented. Through systematic, detailed analysis of historical topographic surveys (NOS T-Sheets back to 1868) and aerial photographs (through 1995) the study has determined the spatial patterns and temporal trends of shoreline change between Tillamook Head, OR and Point Grenville, WA. In addition, sediment accumulation rates over three periods since the late 1800s have been derived for each of the sub-cells.

- A multibeam survey of the region off Grays Harbor and Grayland Plains was conducted to provide accurate and detailed bathymetry and backscatter data. The survey reveals several distinct depressions along both the north and south sides of the Grays Harbor entrance. A series of obliquely-angled depressions south of the south jetty in water depths from 10-16 m, are up to $2 \mathrm{~m}$ deep, $200 \mathrm{~m}$ wide, and 1 $\mathrm{km}$ long. A wider and longer shore-perpendicular depression exists north of the Grays Harbor entrance. The bottoms of the depressions contain well-rounded gravel-size sediment probably of glacial origin. The depressions are surrounded by fine to medium-sized sand that originated from the Columbia River. 
- Climate changes associated with El Niño cycles and the Pacific Decadal Oscillation affect precipitation and thus river flow and sediment discharge. There is also a correlation with shifting storm tracts, frequency, and severity and thus wave height and direction, and sea level. These factors may have a measurable effect on both the sediment discharge from the Columbia River and on the magnitude and direction of longshore sediment transport along the coast. The degree to which these climate change factors effect coastal morphology is of great interest and they are currently being studied.

- The construction of jetties at the entrances to the Columbia River and Grays Harbor have had a profound effect on the local sea floor morphology and the positions of the adjacent shorelines. Detailed sediment budgets at both estuary entrances accounting for these changes are providing critical data necessary to calibrate and predict future shoreline change.

- The magnitude and direction of longshore sediment transport along the beaches of the CRLC, and ultimately the shoreline change that results from gradients in transport, are sensitive to the magnitude and direction of incoming waves. Sensitivity analyses are improving the ability to accurately numerically simulate the shoaling and refraction of incoming waves. Extensive field experiments in which waves, currents, sea level, and suspended-sediment concentration are measured will be used to test and calibrate wave and sediment transport models.

- The beaches of the CRLC undergo morphological change, including net accretion and erosion, at several space and time scales. A variety of highly accurate GPS techniques are used to conduct extensive and detailed mapping of the beach from the dune fields to $-10 \mathrm{~m}$ elevation (MSL) along each of the four sub-cells. Results are used to document short-term changes in beach elevation and shoreline position, as input to shoreline change models, and in assessments of susceptibility to coastal flooding and beach erosion.

Geological data from the study show that the beaches in the CRLC have grown seaward nearly uniformly over the last few thousand years at rates on the order of $0.5-1.0 \mathrm{~m}$ per year (Peterson et al., 1999). In contrast, shoreline progradation of tens of meters per year occurred following jetty construction at the Columbia River and Grays Harbor during the early 1900s (Kaminsky et al., 1999). The highest rates of beach accretion occurred adjacent to the jetties during the first few decades following their construction. Over several decades, the shorelines at distances of up to $20 \mathrm{~km}$ from the jetties also advanced seaward, while accretion rates next to the jetties tended to decrease.

Combined bathymetric change and shoreline change analysis has revealed that much of the historical accretion patterns and rates are primarily due to sediment redistribution from the ebb-tidal deltas of the Columbia River and Grays Harbor to the adjacent coasts. After an initial flux of onshore sediment movement, the ebb-tidal deltas have diminished as a sediment source, corresponding to slowing accretion rates and/or the onset of shoreline erosion adjacent to the jetties in more recent decades. In addition to the decrease in 
sediment supply to the beaches from the ebb-tidal deltas, river flow regulation via dam and reservoir construction has diminished the sediment load of the Columbia River by approximately two-thirds over the historical period (Gelfenbaum et al., 1999). The decrease in peak flood flows, which reduces the amount of sand carried by the Columbia River, may also reduce the discharge of sand from the estuary entrance to feed the adjacent coast.

These recent research findings have important management implications. As the sediment supply to the beaches from both ebb-tidal deltas and the Columbia River continues to decline, it is apparent that there is increased potential for shoreline retreat. It is anticipated that the shoreline will continue to evolve over several decades in response to the declining sediment budget, and shoreline sections that advance will tend to do so as a result of shoreline retreat elsewhere in the littoral system. Therefore, the coastal management community will need to consider both short-term and long-term responses to deal with these anticipated changes.

The strategic use of dredged material from the estuary entrances will be increasingly important in mitigating erosion trends. In fact, the U.S. Army Corps of Engineers, in cooperation with many state and federal agencies and local groups, are actively engaged in developing ways to enhance the beneficial use of dredged material at the mouth of the Columbia River. The Corps of Engineers moves an average of $3.4 \times 10^{6} \mathrm{~m}^{3}$ per year of sand from the navigation channel in the lower estuary. Investigations suggest a relationship between the offshore steepening of the beach profile and shoreline change at Fort Canby, just north of the Columbia River entrance. These findings may help optimize innovative placement of dredged materials to reduce coastal erosion.

In consideration of the relatively low-elevation barrier plains that have grown seaward since the early 1900s, it is apparent that these accreted lands are susceptible to flooding and severe erosion from the next Cascadia Subduction Zone earthquake. However, information from this study, such as the location of previous earthquake scarps (e.g., Peterson et al., 1999), land elevation data, and modeling results could be factored into maps that outline areas of greater and lesser susceptibility to these events.

\section{SUMMARY}

Study results to date have enabled the formulation of conceptual models of littoral cell behaviour that will continue to be tested and refined with additional data as part of the scientific research process. However, these conceptual models are already useful tools for assisting managers to address relevant and important questions in the decision-making process.

Improved prediction of coastal change will require continued monitoring to provide an accurate record of local shoreline conditions and promote a better understanding of the cause and effect relationships behind coastal change scenarios. Combined monitoring and modeling programs are important for validating shoreline change predictions and enhancing predictive capabilities, to facilitate long-term planning. In addition, the 
collection of new data sets (e.g., LIDAR, high resolution bathymetric surveys, and bottom currents) may be necessary to address specific science or management questions. For example, new data could be used to reveal the transfer of sand between the inner-shelf and the beach, which would have implications for assessments of future coastal change, the use of dredged material, and the influence of man-made structures on sediment entrainment or deposition.

\section{BIBLIOGRAPHY OF STUDY PUBLICATIONS \\ Papers and Abstracts}

Buijsman, M.C., and Kaminsky, G.M. 1999. Modelling and predicting decadal scale coastal change in the Pacific Northwest, USA, Abstract, EOS, Transactions, $A G U$ Fall Meeting, 80 (46), Supplement, p. F549.

Côté, J.M. 1999. The Measurement of Nearshore Bathymetry on Intermediate and Dissipative Beaches, M.S. Thesis, Oregon State University, Corvallis, Oregon, $102 \mathrm{p}$.

Côté, J.M., Holman, R.A., and Ruggiero, P. 1998. Nearshore bathymetry within the Columbia River littoral cell, Poster, EOS, Transactions, AGU Fall Meeting, 79 (45), Supplement, p. F450.

Cross, V.A., Twichell, D.C., Parolski, K.F., and Harrison, S.E. 1998. Archive of Boomer Seismic Reflection Data Collected aboard R/V Corliss Cruise CRLS97007 off Northern Oregon and Southern Washington Inner Continental Shelf, U.S. Geological Survey Open-File Report 98-351, 2 CD-ROMs.

Daniels, R.C., Huxford, R.H., and McCandless, D. 1998. Coastline mapping and identification of erosion hazard areas in Pacific County, Washington, ESRI 1998 User Conference.

Daniels, R.C., Ruggiero, P., and Weber, L.E. 1999. Washington Geodetic Control Network: Report and Station Index, Washington State Department of Ecology, Coastal Monitoring \& Analysis Program, Publication No. 99-103, 268 p.

Gelfenbaum, G., and Kaminsky, G.M. (editors) 1999. Southwest Washington Coastal Erosion Workshop Report, 1998, U.S. Geological Survey Open File Report 99-524, $182 \mathrm{p}$.

Gelfenbaum, G., Kaminsky, G.M., Sherwood, C.R., and Peterson, C.D. 1997. Southwest Washington Coastal Erosion Workshop Report, U.S. Geological Survey Open File Report 97-471, 102 p.

Gelfenbaum, G., Sherwood, C.R., Peterson, C.D., Kaminsky, G.M., Buijsman, M., Twichell, D.C., Ruggiero, P., Gibbs, A.E. and Reed, C. 1999. The Columbia River 
littoral cell: A sediment budget overview, Proceedings of Coastal Sediments '99, ASCE, pp. 1660-1675.

Gibbs, A.E., and Gelfenbaum, G. 1998. Bathymetric change and coastal erosion: the Oregon-Washington coast, Poster, EOS, Transactions, AGU Fall Meeting, 79 (45), Supplement, p. F451.

Gibbs, A.E., and Gelfenbaum, G.R. 1999. Bathymetric change off the Washington-Oregon coast, Proceedings of Coastal Sediments '99, ASCE, pp. 1627-1642.

Huxford, R.H. 1998. Historical map recovery using multiple, integrated ESRI programs, Paper, ESRI 1998 Users Conference.

Jol, H.M., Peterson, C., Vanderburgh, S., and Phipps, J. 1999. Ground penetrating radar as a regional coastal mapping tool, Association of American Geographers, 95th Annual Meeting, Abstract on CD-ROM.

Jol, H.M., Peterson, C.D., Vanderburgh, S., and Phipps, J. 1997. Imaging coastal accretion in barrier beach and dune ridge complexes: Columbia River littoral cell, Abstract, Geological Society of America, Annual Meeting, A-38.

Jol, H.M., Peterson, C.D., Vanderburgh, S., and Phipps, J. 1998. GPR as a regional geomorphic mapping tool: shoreline accretion/erosion along the Columbia River littoral cell, GPR '98 International Meeting, pp. 257-262.

Jol, H.M., Vanderburgh, S., and Havholm, K.G. 1998. GPR studies of coastal aeolian environments: examples from foreshore, crescentic, and parabolic dunes, Oregon and North Carolina, USA, GPR '98 International Meeting, pp. 681-686.

Jol, H.M., Vanderburgh, S., and Havholm, K. 1998. Ground penetrating radar studies of coastal aeolian environments, Joint Meeting of the West Lakes Division of the Association of American Geographers (49th Annual Meeting) and Wisconsin Geographical Society (52nd Annual Meeting), Programs and Abstracts, p. 18.

Kaminsky, G.M., and Gelfenbaum, G. 1999. The Southwest Washington Coastal Erosion Study: Research in support of coastal management, Proceedings of Coastal Zone '99, ASCE, pp. 737-739.

Kaminsky, G.M., Buijsman, M., Gelfenbaum, G.R., Ruggiero, P., Jol, H.M., Gibbs, A., and Peterson, C.D. 1999. Synthesizing geological observations and processresponse data for modeling coastal change at a management scale, Proceedings of Coastal Sediments '99, ASCE, pp. 1708-1723.

Kaminsky, G.M., Daniels, R.C., McCandless, D., and Ruggiero, P. 1999. Mapping erosion hazard areas in Pacific County, Washington, Journal of Coastal Research, Special Issue 28, pp. 158-170. 
Kaminsky, G.M., Jol, H.M., Cowell, P.J., Ruggiero, P., and Gelfenbaum, G. 1999. Measuring and modeling coastal progradation, catastrophic shoreline retreat, and shoreface translation along the coast of Washington State, USA, Abstract, The Non-Steady State of the Inner Shelf and Shoreline: Coastal Change on the Time Scale of Decades to Millennia in the late Quaternary, Abstracts with Programs, Inaugural Meeting of IGCP Project \#437 "Coastal Environmental Change During Sea Level Highstands", p. 107.

Kaminsky, G.M., Ruggiero, P., Gelfenbaum, G., and Peterson, C. 1997. Long-term coastal evolution and regional dynamics of US Pacific Northwest littoral cell, Proceedings of Coastal Dynamics '97, ASCE, pp. 614-623.

Kaminsky, G.M., Ruggiero, P., and Gelfenbaum, G.R. 1998. Monitoring coastal change in southwest Washington and northwest Oregon during the 1997/98 El Niño, Shore and Beach, 66 (3), pp. 42-51.

Moritz, H.R., Kraus, N.C., Hands, E.B., and Slocum, D.B. 1999. Correlating oceanographic processes with seabed change, mouth of the Columbia River, USA, Proceedings of Coastal Sediments '99, ASCE, pp. 1643-1659.

Oltman-Shay, J., Smith, F., Secan, J., Ruggiero, P., Pruis, M., Putrevu, U., Kaminsky, G., Echert, D., Cooksan, A., Côté, J., Boss, E., and Bussey, R. 1999. Infragravityfrequency-band waves and currents on a Washington coast beach, Abstract, EOS, Transactions, AGU Fall Meeting, 79 (45), Supplement, p. F446.

Peterson, C.D., Gelfenbaum, G.R., Jol, H.M., Phipps, J.B., Reckendorf, F., Twichell, D.C., Vanderburgh, S., and Woxell, L.K. 1999. Great earthquakes, abundant sand, and high wave energy in the Columbia Cell, USA, Proceedings of Coastal Sediments '99, ASCE, pp. 1676-1691.

Peterson, C.D., Morton, R.A., Phipps, J.B., Qualman, D.R., Sorensen, O., and Vanderburgh, S. 1999. Great earthquake records in Holocene tidal-flat and accretionary-bank deposits from Willapa Bay and Grays Harbor tidal-basins of the central Cascadia Subduction Zone, USA, Abstract, EOS, Transactions, AGU Fall Meeting, 80 (46), Supplement, p. F733.

Phipps, J., Jol, H., Peterson, C., and Vanderburgh, S. 1997. The effect of a great subduction zone earthquake on a coastal Washington beach, Poster, EOS, Transactions, AGU Fall Meeting, 78 (46), Supplement, p. F335.

Qualman, D.R., Peterson, C.D., Jol, H.M., and Herb, A. 1998. Vibracore study of surfzone facies and responses to 1997-98 El Niño, Columbia River littoral cell, NW Oregon-SW Washington, USA, Poster, EOS, Transactions, AGU Fall Meeting, 79 (45), Supplement, p. F450. 
Reckendorf, F. 1998. Geologic hazards of development on sand dunes along the Oregon coast, In: Burns, S. (editor), Environmental, groundwater, and engineering geology: Applications from Oregon, pp. 429-438.

Reckendorf, F. 1998. Mapping shoreline from post south jetty (1885) through 1995 along the Clatsop Plains in Oregon, Oregon Academy of Science Conference, pp. 30-31.

Ruggiero, P., and Kaminsky, G.M. 1998. Morphologic length scales on high energy dissipative beaches. Abstract, EOS, Transactions, AGU Fall Meeting, 79 (45), Supplement, p. F445.

Ruggiero, P., Côté, J., Kaminsky, G.M., and Gelfenbaum, G.R. 1999. Scales of variability along the Columbia River littoral cell, Proceedings of Coastal Sediments '99, ASCE, pp. 1692 - 1707.

Ruggiero, P., Gelfenbaum, G., Kaminsky, G., and MacMahan, J. 1999. Medium- largescale nearshore variability of high energy dissipative beaches, Abstract, EOS, Transactions, AGU Fall Meeting, 80 (46), Supplement, p. F547.

Ruggiero, P., Kaminsky, G.M., Komar, P.D., and McDougal, W.G. 1997. Extreme waves and coastal erosion in the Pacific Northwest, Proceedings of Waves '97, ASCE, pp. 947-961.

Ruggiero, P., Kaminsky, G.M., Komar, P.D., and Plant, N. 1998. Coastal morphologic variability of high energy dissipative beaches, Proceedings of the 26th International Conference on Coastal Engineering, ASCE, pp. 3258 -3251.

Thayer, B., Jol, H.M., Kaminsky, G.M., and Ruggiero, P. 1999. Detailed ground penetrating radar profiles showing coastline depositional rates, Washington, Association of American Geographers, 95th Annual Meeting, Abstract on CDROM.

Voigt, B. 1998. Glossary of Coastal Terminology, Washington State Department of Ecology, Coastal Monitoring \& Analysis Program, Publication No. 98-105, 87 p.

Voigt, B. 1998. Merging coastal research and policy for improved coastal hazard management, Poster, The Coastal Society Conference.

Voigt, B. 1999. The Washington Coastal Information Clearinghouse: Resources for improved coastal management, Proceedings of Coastal Zone '99.

Wolf, S.C., Hamer, M.R., and McCrory, P.A. 1997. Quaternary Geologic Investigations of the Continental Shelf Offshore Southern Washington and Northern Oregon, U.S. Geological Survey Open File Report 97-677. 
Wolf, S.C., McCrory, P.A., and Hamer, M.R. 1998. Investigations of Late Quaternary Geologic Features in Willapa Bay, Washington, U.S. Geological Survey Open File Report 98-589.

Wolf, S.C., Nelson, H., Hamer, M.R., Dunhill, G., and Phillips, R.L. 1999. The Washington and Oregon Mid-Shelf Silt Deposit and its Relation to the Late Holocene Columbia River Sediment Budget, U.S. Geological Survey Open File Report 99-173.

Woxell, L.K. 1998. Prehistoric Beach Accretion Rates and Long-Term Response to Sediment Depletion in the Columbia River Littoral System, USA, M.S. Thesis, Portland State University, Portland, OR, 206 p.

Woxell, L.K. 1998. Prehistoric beach accretion rates used to predict long-term response to sediment depletion in the Columbia River littoral system, Abstract, Oregon Academy of Science Conference.

\section{Unpublished Reports}

Daniels, R., and Huxford, R.H. 1997. NOAA Topographic sheets: Error assessment of vectorized lines based on coordinates from NGS survey markers, Report to the National Geodetic Survey.

Daniels, R., and Ruggiero, P. 1997. Project report for the Washington coastal geodetic control project, Report to the National Geodetic Survey.

Daniels, R.C. 1999. Project report for the Washington coastal gauge control project, conducted for Evans-Hamilton, Inc. as part of a U.S. Army Corps of Engineers study concerning Willapa Bay, Washington.

Kaminsky, G., Ruggiero, P., McCandless, D., Daniels, R., McInnis, J., and Lindstrum, E. 1999. Shoreline change at Fort Canby State Park, Report to the Washington State Parks and Recreation Commission.

Kaminsky, G., Ruggiero, P., McCandless, D., Lindstrum, E., McInnis, J., and Daniels, R. 1999. Road wash-outs and shoreline change at Damon Point, Washington, Report to the Washington State Parks and Recreation Commission.

Voigt, B., and Ruggiero, P. 1998. Initial evaluation of Ocean Shores shoreline monitoring data, Report to the Ocean Shores City Planners Office, 3 p.

\section{Video}

Wessells, S.M., Gelfenbaum, G., and Kaminsky, G. 1998. At ocean's edge: Coastal change in Southwest Washington, Washington State Department of Ecology, Coastal Monitoring \& Analysis Program, Publication No. 98-116 (video), 20 min. 


\section{ACKNOWLEDGEMENTS}

We would like to thank Brian Voigt for his help in organizing the workshop and Emily Lindstrum and Laura Kerr for their assistance in preparing the workshop. Much thanks goes to Laura Kerr and Brian Voigt for their help in preparing this workshop report. Finally, we would like to thank John Chin and Alan Cooper of the U.S. Geological Survey for their thorough review of this report. 


\section{Columbia River Littoral Cell}

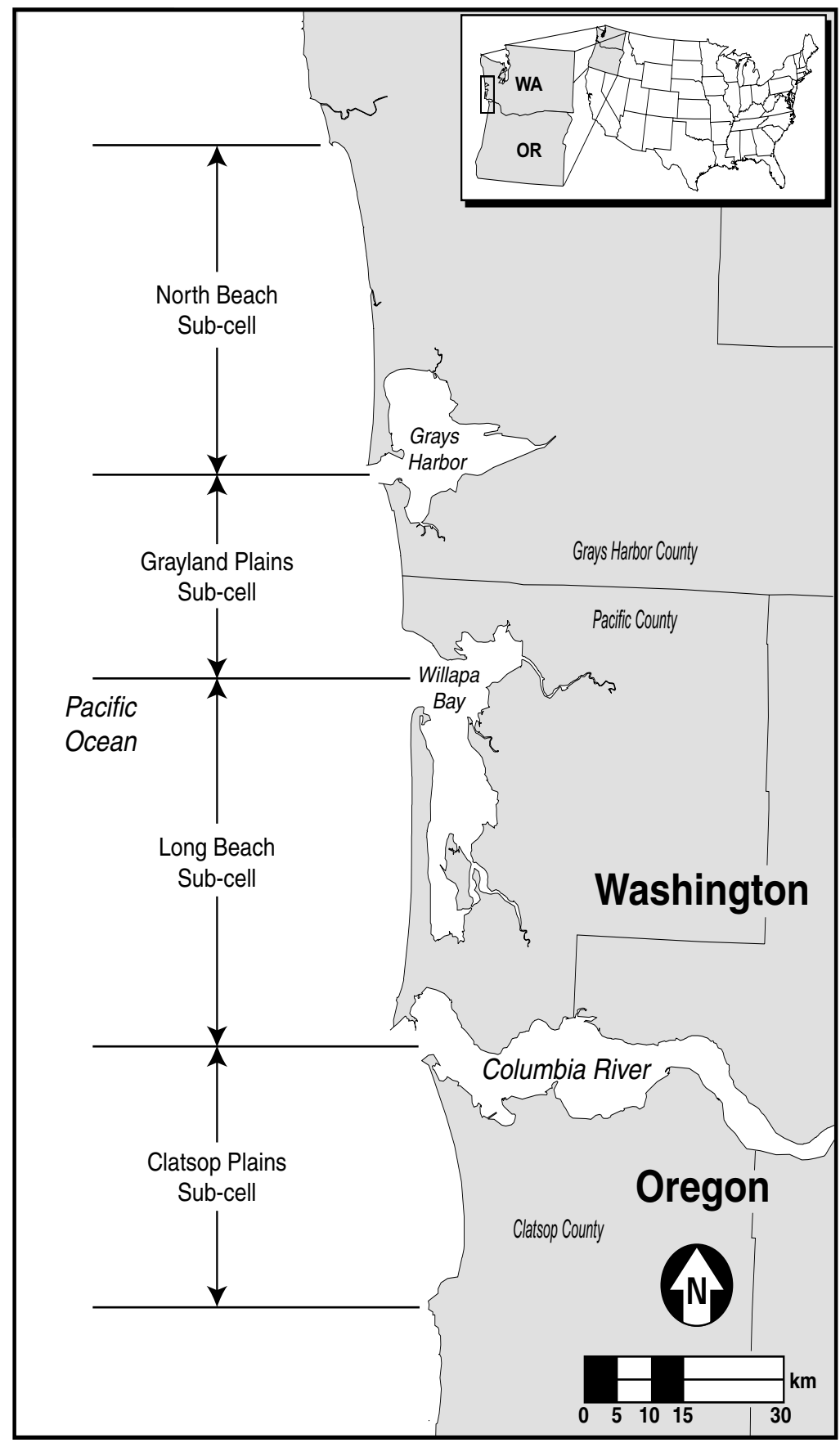

Figure 1. Columbia River littoral cell map. 
FOURTH

SOUTHWEST WASHINGTON COASTAL EROSION STUDY WORKSHOP

\author{
Olympia, Washington \\ November 17-19, 1999 \\ WORKSHOP AGENDA
}

\title{
Wednesday, November 17
}

0800 PICK-UP AT HOTEL FOR SHUTTLE TO WORKSHOP

0815 Welcome

G. Gelfenbaum, USGS

G. Kaminsky, DOE

0830 Motivation, goals, and status of USGS/DOE study

G. Gelfenbaum, USGS

0900 Integrating shelf and coastal stratigraphy to derive a Holocene record of coastal evolution

D. Twichell, USGS

0930 Significance and dating of tephra occurrences

L. Phillips, USGS

0945 Preliminary barrier volume estimates

A. Herb, Portland St. U.

1000 BREAK

1030 Sand dunes along the Washington coast

J. Phipps, Grays Harbor CC

1045 Beach-dune-ridge age correlations: proxies for pre-historic shorelines in the Columbia River littoral cell

C. Peterson, Portland St. U.

1100 Modeling shoreface and barrier response to subsidence events

P. Cowell, U. of Sydney 
1115 History of sand sequestering in a Holocene bay-margin spit complex, Willapa Bay

B. Morton, USGS

1130 Preliminary results and interpretations of the sediment fill of Willapa Bay and Grays Harbor S. Vanderburgh, UCFV

1145 Presenting geologic data in a web-based GIS D. Percy, Portland St. U.

1200 LUNCH \& Posters

1330 Morphostratigraphic and chronologic similarities of Holocene deposition on three US coasts - resolving tectonic, eustatic, and climatic influences

B. Morton, USGS

1345 Frameworkers: what's done, to do, and enough already?

C. Peterson, Portland St. U.

1415 Discussion of geologic time scale studies

1445 BREAK

1500 Historical evolution of the CRLC barriers

G. Kaminsky, DOE

1530 Quantifying shoreline variability and mapping errors

R. Daniels, DOE

1545 Bathymetric volume change analysis

A. Gibbs, USGS

1600 Preliminary results of a multibeam bathymetry and backscatter survey

R. Flood, SUNY-SB

1615 Discussion and Posters

1715 Session ends

1830 SOCIAL MIXER \& DINNER (sponsored by SWCES at the Schmidt House)

\section{Thursday, November 18}

0800 PICK-UP AT HOTEL FOR SHUTTLE TO WORKSHOP

0815 The inner shelf - source or sink for beach sand? D. Twichell, USGS

0830 Role of tidal deltas in the sediment budget $\quad$ C. Sherwood, USGS 
0845 High-resolution GPR results

0900 Shoreline change modeling results

0930 Status of historical scale evolution studies

1000 BREAK

1030 Climate change and variability: considering impacts on coastal morphology in the Columbia River littoral cell

1045 Climate effects on Columbia River sand transport and total load

1100 Status of COE coastal projects

1115 South Beach and Halfmoon Bay, Grays Harbor coastal processes and shoreline erosion stabilization measures

1130 Process-based tidal inlet modelling

1145 Discussion \& Posters

1230 LUNCH

1330 Currents on the SW WA shoreface - a first look

1345 SWAN wave model sensitivity to variation in model formulation

1400 Preliminary SWAN wave modeling based on climatological data

1415 Grays Harbor wave refraction experiment

1430 Data collection for establishing numerical models of Grays Harbor

1445 U.S. Army Corps of Engineers activities at the mouth of the Columbia River 1999-2000
G. Kaminsky, DOE

M. Buijsman, DOE

G. Kaminsky, DOE
D. Jay, Oregon Graduate Inst.

E. Nelson, $\mathrm{COE}$
D. Simpson, PIE

M. Stive, Delft U.
P. Howd, USF

M. Palmsten, USF

K. Hanson, USGS

G. Gelfenbaum, USGS

M. Cialone, WES

H. Moritz, COE

1500 BREAK 
1545 Columbia River mouth dredged material disposal plans

V. Shepsis, PIE

1600 Scales of morphological variability from event response to interannual change

P. Ruggiero, DOE

1630 Discussion \& Posters

1830 DINNER (optional at Jazmines Restuarant)

\section{Friday, November 19}

0800 PICK-UP AT HOTEL FOR SHUTTLE TO WORKSHOP

0815 CRLC sediment budget-What does it say about the source?

G. Gelfenbaum, USGS

0845 GIS/Database group report

R. Daniels, DOE

0915 Coastal susceptibility and decision support system

B. Voigt, DOE

0945 Discussion

1015 BREAK

1030 Break-out groups: Develop list of results and products for each task

1130 Break-out groups report on products

1200 LUNCH

1300 Objective evaluation of Study

B. Morton, USGS

M. Stive, Delft U.

1400 Break-out groups: Where do we go from here?

1530 BREAK

1600 Break-out groups report on the future

1700 End of Workshop 


\title{
INTEGRATING SHELF AND COASTAL STRATIGRAPHY TO DERIVE A HOLOCENE RECORD OF COASTAL EVOLUTION
}

\author{
Dave C. Twichell, U.S. Geological Survey \\ VeeAnn A. Cross, U.S. Geological Survey \\ April Herb, Portland State University \\ Sandy Vanderburgh, University College of the Fraser Valley \\ Curt D. Peterson, Portland State University \\ Jim B. Phipps, Grays Harbor College
}

\begin{abstract}
Integration of seismic-reflection data collected on the southwest Washington shelf with drill hole results collected from the beaches and barriers and seismic and drill hole data from the bays in concert with a sea-level curve from Grays Harbor (Peterson and Phipps, 1992) are used to reconstruct the Holocene evolution of this coastal system. Two erosional surfaces were identified in these data sets: a lowstand surface cut during the last lowstand of sea level and a ravinement/flooding surface formed by the transgression of the shoreline across this shelf during the Holocene rise of sea level. A map of the lowstand surface shows a deep valley extending across the shelf from the Columbia River to Astoria Canyon, a smaller, shallower valley extending across the study area from Grays Harbor, and no valley seaward of Willapa Bay. A subdued ridge seaward of Willapa Bay separates the deeper Willapa Bay from the shelf. The map of the ravinement/flooding surface shows a smooth shelf surface indicating that the river valleys cut during the lowstand were completely filled prior to the shoreline transgressing across them. The presence of Missoula flood deposits in the Columbia River valley (Gates, 1994) indicate significant filling of this valley by fluvial deposits prior to $12,000 \mathrm{yr} \mathrm{BP}$, and age dates from the Warrenton hole indicate that valley filling continued to keep pace with the rise in sea level through the remainder of the Holocene as well. The valley extending out of Grays Harbor also is largely filled by sandy sediments, however, the mineralogy of these sediments (Peterson and Phipps, 1972) and the shoreward-dipping reflectors in the valley fill suggest that it was infilled by the shoreward transport of sand from the shelf rather than fluvially derived sand from local rivers that drain into Grays Harbor. Based on the depth of this valley at the seaward edge of the study area $(-71 \mathrm{~m})$ it started filling about 11,000 yr BP. The shallow sill across the mouth of Willapa Bay (about - $35 \mathrm{~m}$ ) kept this bay from filling until 7,000-8,000 yr BP.
\end{abstract}

Sediment overlying the ravinement surface is distributed in Willapa Bay, under the beaches, and on the shelf. North of Grays Harbor, consolidated Tertiary strata are exposed on parts of the middle and inner shelf, younger Holocene sediment provides a thin and discontinuous cover on the innermost shelf and this unit thickens to approximately $3 \mathrm{~m}$ under the beaches. The shelf off Grayland is covered by a discontinuous veneer of Holocene sediment that is less than $1-\mathrm{m}$ thick. Shoreward of this part of the shelf the Holocene sediment is 20-30 m thick under the beaches. The Holocene shelf deposits increase in thickness south of the mouth of Willapa Bay and reach $50 \mathrm{~m}$ off the mouth of 
the Columbia River. This deposit thins shoreward, and under Long Beach the shelf and beach deposits are 17-40 m thick. Holocene deposits on the shelf south of the Columbia River reach $25 \mathrm{~m}$ thickness on the inner shelf, thicken shoreward, and reach 30-40 m under the dune ridges of the Clatsop Plains.

The coring and seismic data indicate that the initial sediment sinks were the Columbia River valley followed by the Grays Harbor valley. Once these valleys were filled, sediments started accumulating on the shelf. The shelf was the principal sediment sink until 7,000-8,000 yr BP when Willapa Bay flooded. The shelf and Willapa Bay were the primary sinks until about 4,000 yr BP when the beaches started to accrete and became a significant sink (Woxell, 1998). The data have been incorporated into a GIS and presently volumes are being computed on 1,000 yr intervals to determine how the distribution of sediment between bays and the shelf varied during the Holocene. Initial calculations show that, within the area that has been mapped so far, roughly half the sediment was deposited in the bays (below the ravinement surface) and the other half is shelf, beach, and Willapa Bay deposits that accumulated above the ravinement surface.

\section{REFERENCES}

Gates, E.B. 1994. The Holocene sedimentary framework of the lower Columbia River basin, M.S. Thesis, Portland State University, Portland, OR, 210 p.

Peterson, C.D., and Phipps, J.B. 1992. Holocene sedimentary framework of Grays Harbor Basin, Washington, USA, SEPM Special Publication No. 48, Society for Sedimentary Geology, pp. 273-285.

Woxell, L.K. 1998. Prehistoric beach accretion rates and long-term response to sediment depletion in the Columbia River littoral system, USA, Master's thesis, Portland State University, Portland, OR, 206 p. 


\title{
SEDIMENTATION RATES AND OCCURRENCES OF TEPHRA IN CORES FROM THE SOUTHWEST WASHINGTON SHELF
}

\author{
R. Lawrence Phillips, U.S. Geological Survey \\ Gita Dunhill, U.S. Geological Survey
}

\begin{abstract}
Eight of ten gravity cores obtained on the Washington-Oregon shelf (Figure 1) contain rare to abundant glass shards, shell lags, and scattered pelecypods in intensely bioturbated sediment. The sand fraction in cores lacking gravel ranges from 78 to 82 percent in the south changing to 79 percent to the north. The deepest core, core 4 at $132 \mathrm{~m} \mathrm{depth}$, is remarkably uniform in sand composition ranging from 71 to 80 percent.
\end{abstract}

C14 dating of shell lags and scattered bivalves in three cores obtained southwest of Grays Harbor identifies the age of the strata, allows determination of sedimentation rates, and identifies possible eruption sources for some of the tephra deposits. The deepest core, core 4, contains the oldest strata dated at $9240 \pm 160$ years BP overlying with an irregular contact glauconite-rich green sand of possible Pleistocene age. Sedimentation rates of 5.4 $\mathrm{cm} / 1000$ years confirm low sedimentation rates for the outer shelf relict sands (Figure 2). Sedimentation rates increase to the east as the depth decreases on the shelf. A date of $6750 \pm 110$ years BP for strata overlying relict green sand in core 6 yields a sedimentation rate of $9.4 \mathrm{~cm} / 1000$ years, whereas, an age of $740 \pm 70$ years BP from a storm shell lag deposit in the upper $25 \mathrm{~cm}$ of strata yields sedimentation rates of $32.4 \mathrm{~cm} / 1000$ years. The change in sedimentation from low to high rates within core 6 suggests that substantial erosion followed by increased sedimentation has occurred in the upper core section. Two dates of $5170 \pm 150$ and $2420 \pm 70$ years BP in core 3 at $84 \mathrm{~m}$ water depth yields sedimentation rates of 20.3 and $18.5 \mathrm{~cm} / 1000$ years showing increasing sedimentation with decreasing shelf depth.

Heavy liquid separations of the sand fraction, with floating of the glass component, identified at least four possible tephra concentrations in the shelf cores. The tephra consist of rare black and clear bubble wall shards, and white, cream to yellowish tan very abundant vesicular shards. Intensive bioturbation and sediment mixing has resulted in vertical displacement of the glass shards from each of the original thin tephra depositional sequences (Figure 2). The tephra-rich beds identified consist of: 1) a thin surficial concentration ranging from 4 to 43 percent glass shards apparently related to the $1980 \mathrm{AD}$ eruption of Mt. St. Helens; 2) a glass shard concentration in core 3 ranging from 22 to 29 percent starting at $50 \mathrm{~cm}$ below the sea floor with an age greater than 2420 years BP which suggests the tephra may be related to the 2900-3900 BP Smith Creek eruption of Mt. St. Helens; 3) a concentration ranging from 15 to 60 percent glass shards found at $20 \mathrm{~cm}$ depth (core 4), $60 \mathrm{~cm}$ depth (core 6), and $120 \mathrm{~cm}$ depth (core 3) may be related to the 6760 BP Mt. Mazama eruption (the glass shard peak in core 6 at $60 \mathrm{~cm}$ depth corresponds to a C14 date of 6750 years BP and identifies this tephra occurrence to the Mt. Mazama eruption); and 4) a glass shard concentration ranging from 24 to 29 percent found at 
depths greater than $70 \mathrm{~cm}$ in core 6 and $90 \mathrm{~cm}$ in core 4 in the relict "green sand" which in core 4 is older than 9240 years BP suggesting that the stratigraphically lowest tephra may be related to either the 11,000-13,000 year BP Swift Creek eruption of Mt. St. Helens or the 11,200 year BP Glacier Peak eruption.

The tephra occurrences along with dating of the core strata identifies distinct timestratigraphic horizons in the shelf deposits that may be correlated to tephra occurrences identified in strata in bore holes drilled in the onshore deposits. The correlation of these offshore time stratigraphic horizons with the onshore strata will further refine the shelf and coastal sand budget for the southwest Washington shelf. 


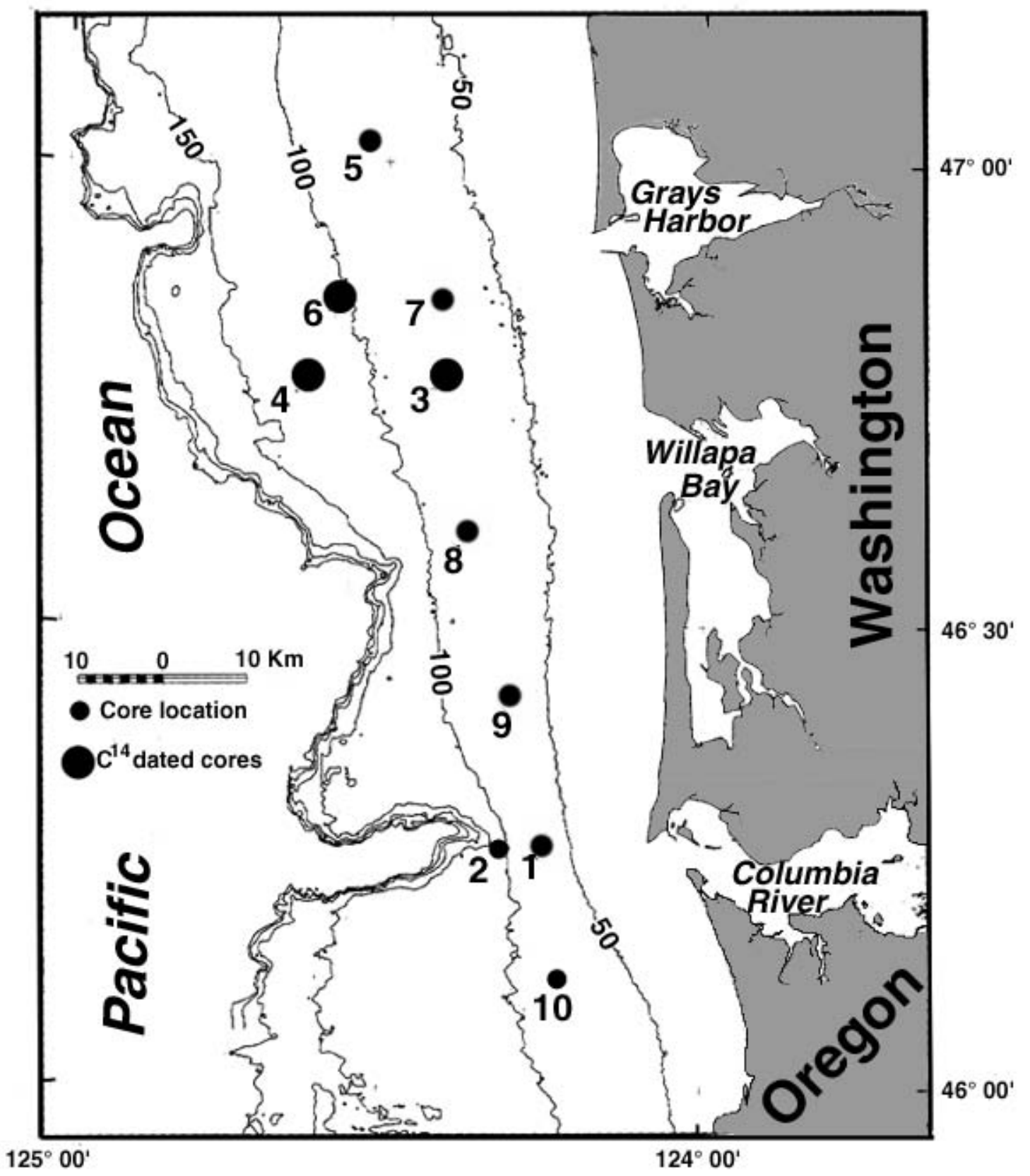

Figure 1. Location of cores obtained on the southwest Washington and northern Oregon shelf. The large circles indicate cores that were dated by $\mathrm{C} 14$ techniques. Contours in meters. 


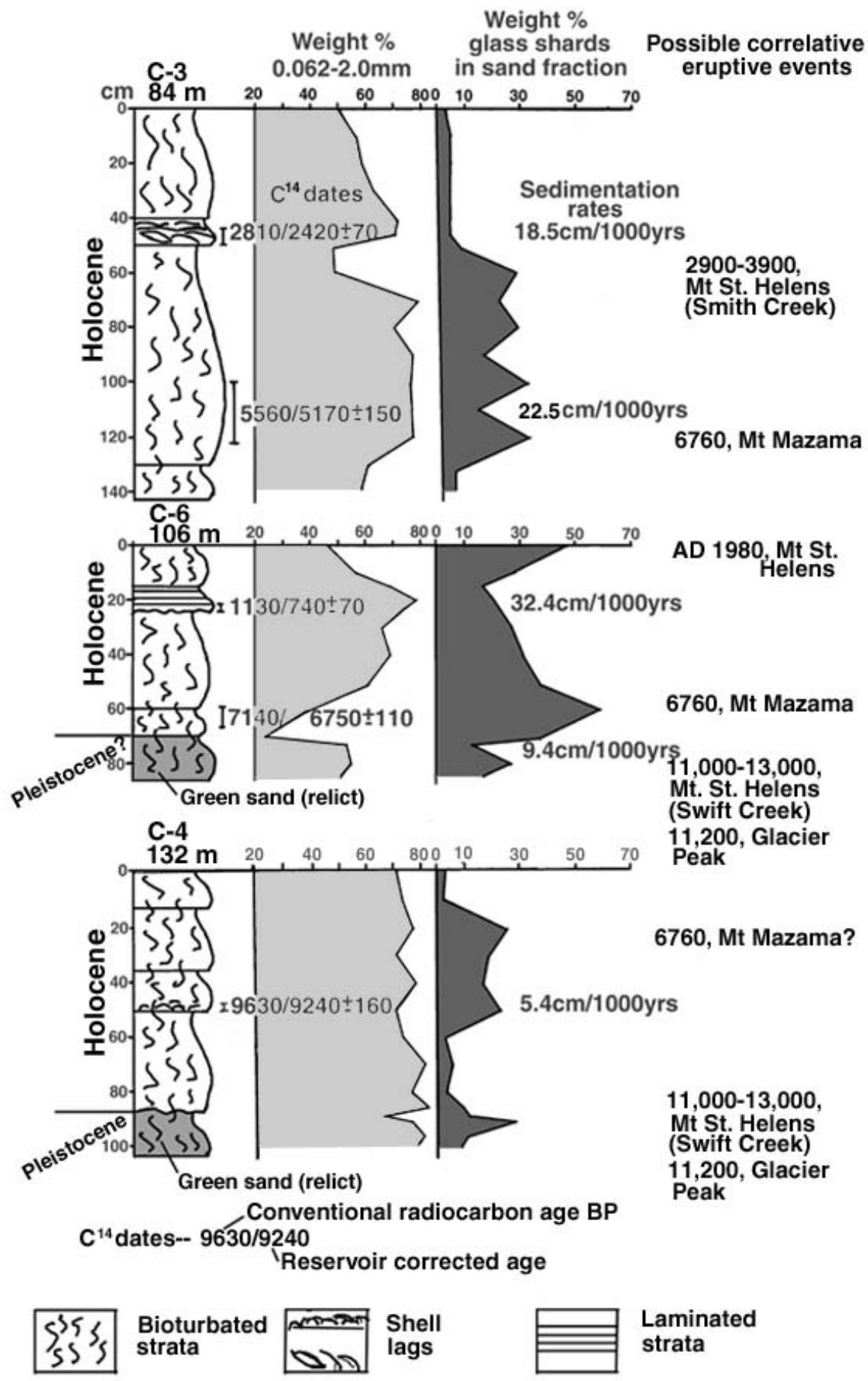

Figure 2. Core stratigraphy, weight percent of $0.062-2.0 \mathrm{~mm}$ size fraction, weight percent glass shards in sand fraction, $\mathrm{C} 14$ dates, sedimentation rates, and possible correlative eruptive events for glass shard occurrences in cores 3, 4, and 6 obtained on the southwest Washington shelf southwest of Grays Harbor. 
PRELIMINARY HOLOCENE BEACH SEDIMENT VOLUME CALCULATIONS

April A. Herb, Portland State University

\section{ABSTRACT}

Historical erosion in parts of the Columbia River littoral cell has sparked research into the rates and mechanisms of deposition in the cell. In this study, sand deposition rates since the pre-historic ( 10,000 years ago) have been calculated, and depositional processes have been inferred.

In order to accomplish this task, 25 drill holes, 42 water wells, 12 geotechnical holes, numerous GPR traces, and surf zone vibracores were used to establish changes in lithology, specifically the erosional truncation and lag that occurred as the surf zone transgressed. This ravinement surface delineates the base of marine sediments deposited in the last 7000 years. Radiocarbon dating of selected samples associated the sedimentation with a time scale and allowed for ground truthing of field observations.

Twenty across-shore cross sections were constructed in order to calculate beach and shelf sediment volumes. The total sediment volume was converted to a long term sedimentation rate using an average age of 6000 years for the whole cell. A total of $7.8 \mathrm{~km}^{3}$ of sediment has accumulated to form the modern barrier beach plains at an average rate of 1.3 million cubic meters per year.

Accumulation of sediment occurred in the southern sub-cells first, due to increased accommodation space caused by the lowstand valley incision and large scale tectonic uplift in the northern sub-cells. 


\section{SAND DUNES ALONG THE WASHINGTON COAST}

Jim Phipps, Grays Harbor College

\section{ABSTRACT}

The linear dune ridges carry a history for each of the three coastal segments, Long Beach, Grayland and North Beach. The dunes show that each of these segments have different histories. These histories can be linked in time to earthquake events that affect all three segments at the same time and in the same way. 


\title{
DUNE RIDGE CORRELATION BETWEEN THE CLATSOP PLAINS AND THE NORTHERN SUB-CELLS OF THE COLUMBIA RIVER LITTORAL CELL: LATE-HOLOCENE PALEO-SHORELINE RECONSTRUCTION OF SOUTHWEST WASHINGTON AND NORTHWEST OREGON, USA
}

\author{
Curt Peterson, Portland State University \\ Frank Reckendorf, Reckendorf and Associates \\ James Phipps, Grays Harbor College \\ Dave Percy, Portland State University \\ Sandy Vanderburgh, University College of Fraser Valley \\ Lorraine Woxell, Portland State University \\ Harry Jol, University of Wisconsin-Eau Claire
}

\begin{abstract}
Beach-dune ridge mapping in the Clatsop Plains has been performed using high-resolution topographic maps, oblique aerial photos, and subsurface sand augering. The results demonstrate a total of 12-14 dune ridges that apparently occur in distinct groups or sets. The sets are numbered from 1 to 5 with Set 1 containing late-historic beach-dune ridges, Set 2 containing early historic (pre-Jetty) ridges, and Set 3 containing 3-4 ridges (Big Dune Complex). The Big Dune Complex includes at least one paleosol dated to about 600 RCYBP by the authors, and is locally overtopped by historic (post-jetty) sand sheets. The Set 3 ridge group is bounded to the west by a prominent subsurface retreat scarp and/or the westward truncation of the paleosol (Woxell, 1998). The Set 3 ridge complex is preceded by a wide gap (Neacoxie Creek-Sunset Lake) which is preceded by a second multi-ridge complex identified as Set 4. Set 4 contains 3-4 ridges, and corresponds to the 3A-B-C dune ridges of Rankin (1983). A prominent pair of ridges (Race Track) in the Set 4 group is recognized along nearly the full length of Clatsop Plains and is dated, from a buried shell midden, to $2.5 \mathrm{ka}$ by the authors. The Set 4 ridges are preceded by another wide gap (locally occupied by HW101) which is preceded by 2-3 smaller dune ridges of Set 5 . The Set 5 ridges are non-continuous, being interrupted by sea stacks, paleo-sea-cliff protrusions, and drainage cutouts near the backedge of the Clatsop Plains. The easternmost ridge of Set 5 has been dated to 4.0 ka by Rankin (1983).
\end{abstract}

Dune ridges of the Long Beach sub-cell, mapped by Phipps (this volume) show similar groupings to those in the Clatsop Plains. Specifically, a cluster of close-spaced ridges located west of Loomis Lake is dated between 0.3 and 1.7 ka by Meyers et al. (1996). The Set 3 ridge group in the Long Beach Peninsula is bounded to the west by a prominent subsurface retreat scarp (Woxell, 1998). East of Loomis Lake a second complex of ridges has been recently dated to $2.5 \mathrm{ka}$ by the authors. The ridge complex located east of the Loomis Lake gap is correlated to the Set 4 dune ridges of Clatsop Plains by ridge number, spatial-gap distribution, and radiocarbon dating. The Set 4 dune ridges of the Long Beach Peninsula do not extend north of Oysterville, due to limited northward spit extension at the time of ridge development. The Set 4 dune ridges of Long Beach Peninsula, south of Oysterville, are preceded by a prominent gap. A third complex of dune ridges occurs 
along the eastern margin of Long Beach Peninsula. These ridges have been dated to $4.2 \mathrm{ka}$ by Meyers et al. (1993). These ridges are correlated to the Set 5 ridges in the Clatsop Plains by spatial-gap distribution and radiocarbon dating. This eastern ridge set is not continuous along the Peninsula due to limited northward extension of the spit at the time of ridge development, and due to subsequent bay-side erosion. High resolution topographic control is needed to extend the ridge sets to the southern end of the Long Beach Peninsula, where dune ridges decrease in average height (Woxell, 1998). The higher-resolution topographic control is also needed to separate the dune ridges of the Set 3 and Set 4 complexes of the mid-Long Beach Peninsula.

Shoreline-parallel dune ridges of the Grayland Plains occur in two groups as previously noted by Cooper (1958) and others (anonymous, 1970s). A western group of 2-3 dune ridges forms the Big Dune Complex, dated between $0.3 \mathrm{ka}$ and $1.0 \mathrm{ka}$ by the authors. This group of dunes is correlated to the Set 3 ridges of the Clatsop Plains by the distinctive buried paleosol and by radiocarbon dating. The Set 3 ridge group in the northern Grayland Plains is bounded to the west by a prominent subsurface retreat scarp (Woxell, 1998). The Set 3 ridges are preceded by a prominent wetland gap. This gap extends to the paleo-sea cliff in southern Grayland Plains and has been recently dated to $1.2 \mathrm{ka}$ by the authors. At the northern end of Grayland Plains, the gap is preceded by a group of 3-4 dune ridges (Phipps, this volume). This dune-ridge complex has been optically dated at $2.5 \mathrm{ka}$ by the authors. This dune-ridge complex is correlated to the Set 4 dune ridges of Clatsop Plains by ridge number, spatial-gap distribution, and dating. Oblique dune ridges are formed at the southernmost end of the Grayland Plains but are not addressed in this regional age correlation. Higher-resolution topographic control is needed to separate the dune ridges of the Set 4 group in the Grayland Plains.

Dune ridges of the North Beach sub-cell occur in one group of up to three ridges, dated between 0.6 and $1.2 \mathrm{ka}$ at Ocean Shores. The ridges decrease to only one in number with distance northward to the Copalis River. No continuous dune ridges extend north of the Copalis River, although a minor ridge is present at the south end of the Moclips embayment. The landward-most paleo-dune ridge at Ocean Shores is characterized by a distinct paleosol, and is correlated to the Set 3 ridges of the Clatsop Plains by both the paleosol and radiocarbon dating. The Set 3 ridge group at Ocean Shores is bounded to the west by a prominent subsurface retreat scarp (Woxell, 1998). Higher resolution topographic control is needed to trace the terminations of the Set 3 dune ridges northward of the Ocean Shores barrier-spit.

\section{CONCLUSIONS}

The apparent correlation of beach-dune ridge Sets 5, 4, and 3, between the four sub-cells yields approximate barrier-plains shoreline positions at 4.0, 2.5, 1.7, 1.2 and $0.3 \mathrm{ka}$ throughout the Columbia River littoral cell. 


\section{ACKNOWLEDGEMENTS}

This work was funded by the U.S. Geological Survey Coastal and Marine Geology Program, under Cooperative Agreement 1434-HQ-96-AG-01612.

\section{REFERENCES}

Cooper, W.S. 1958. Coastal sand dunes of Oregon and Washington, Geological Society of America Memoir, 72, 167 p.

Meyers, R.A., Smith, D.G., Jol, H.M., and Peterson, C.D. 1996. Evidence for eight great earthquake-subsidence events detected with ground penetrating radar, Willapa barrier, Washington, Geology, 24, pp. 99-102.

Phipps, J.B. this volume. Sand dunes along the Washington coast, Southwest Washington Coastal Erosion Study Workshop Report 1999, U.S. Geological Survey Open-File Report.

Rankin, D.K. 1983. Holocene geologic history of the Clatsop Plains foredune ridge complex, M.S. Thesis, Portland State University, Portland, Oregon, 175 p.

Woxell, L.K. 1998. Prehistoric beach accretion rates and long-term response to sediment depletion in the Columbia River littoral system, USA, M.S. Thesis, Portland State University, Portland, Oregon, 206 p. 


\title{
MODELING SHOREFACE AND BARRIER RESPONSE TO SUBSIDENCE EVENTS
}

\author{
Peter Cowell, Coastal Studies Unit, Institute of Marine Science, University of \\ Sydney
}

\begin{abstract}
Simulated evolution of the Long Beach barrier-strand-plain was undertaken using the Shoreface Translation Model (Cowell et al., 1995) to assess the effects and likelihood of shoreface rotation (steepening and deepening of the shoreface), including sequestering by the prograding barrier of sand from the inner shelf (in supplementing sand supplied from the Columbia River via littoral transport); the effects of episodic earthquake-induced subsidence on barrier evolution; and recession estimates for the present coast due to a future seismic event, calibrated against past responses to such events.
\end{abstract}

Preliminary results suggest that shoreface rotation is a necessary behaviour to obtain observed inner-shelf morphology, and that this makes the time interval between subsidence events more important than event magnitude in governing coastal recession in response to events. Initial, predictive implications are that a) a future subsidence event may cause almost twice as much recession as predicted on the basis of classic Bruun concepts and $b$ ) inner-shelf sand source contributed much less that 50 percent toward the strand-plain progradational volume.

A tendency toward deepening of the shoreface over time can be expected where the general depth of the inner-continental shelf is less than a long-term equilibrium (Roy and Cowell, 1998). Although little is known theoretically about shelf equilibrium, new interpretations of shoreface sediment patterns in the context of shoreface evolution, together with evidence from radiometric dating and computer modeling, suggests that the presence of a shoreface ravinement is the result of long-term lowering of the shoreface (Cowell et al., in press). Time-dependent geometric parameters in the Shoreface Translation Model (STM) can simulate rotational deepening and steepening of the shoreface. Such simulation involves increasing the parameter that specifies the seaward depth of the "upper shoreface" in the STM.

Estimates of progradation rates were used to derive inputs concerning sediment supply based on the work of Woxell (1998). The prehistoric rate of sediment supply was assumed constant (statistically stationary). Based on the geometry of the progradational wedge, the volume rate of deposition in the strand plain before $1200 \mathrm{BP}$ is $13.57 \mathrm{~m}^{3} \mathrm{a}^{-1}$ per meter of shoreline, decreasing to about $7 \mathrm{~m}^{3} \mathrm{a}^{-1} \mathrm{~m}^{-1}$ after $1200 \mathrm{BP}$. Simulated sand supply was assumed to derive from two sources: a) the Columbia River via littoral transport; and b) the inner-continental shelf through the effects of shoreface rotation. Under conditions of invariant shoreface dimensions (classic Bruun assumption), all the sand must be sourced from littoral transport. With shoreface rotation, sand comes from both sources. 
Without additional information, we cannot know in advance the proportions supplied from each source since shoreface rotation is controlled in part by the evolution of the strand plain itself (a non-linear problem). Thus, the appropriate littoral sand input can be estimated only through successive iterations of the simulated evolution. The criteria for convergence toward a correct solution for littoral sand supply include replication of a) the progradation width of the strand plain and b) the topographic and stratigraphic geometry measured in the field.

STM simulations of sea-level fluctuations involved sudden subsidence events, followed by full rebound during the next time step (with these successive steps assumed to entail $\Delta t=0$ and $\Delta t=100$ years, respectively). Quake magnitude-frequency was based on Atwater and Hemphill-Haley (1997): subsidence magnitudes were assumed proportional to the period of time since the previous event, with a maximum subsidence of $2 \mathrm{~m}$. Stable sea levels were applied in subsequent time steps until the next event. Figure 1 compares simulated strand plains for a) an invariant shoreface with constant shoreface parameters $\left(h_{*}=15\right.$, $L_{*}=3000, L_{o}=2000$, being upper-shoreface depth and width and active width of the lower shoreface, respectively), and b) shoreface rotation with a shoreface deepening during inter-quake periods at a rate of $\Delta h_{*}=1 \mathrm{~m}$ per 100 years until the occurrence of the next quake. The invariant-shoreface simulation follows classic Bruun assumptions whereas the rotational-shoreface simulation assumes that the general elevation of the inner-continental shelf surface is shallower than the long-term (order many millennia) equilibrium surface. During each quake for the rotational case, the depth of the upper shoreface was reduced to $h_{*}=15 \mathrm{~m}$ to simulate the effects of longer response time, and the infinitesimal time available, for shoreface adjustment in deeper water during a subsidence event.

For the invariant-shoreface simulation, sediment supply was set at $1358 \mathrm{~m}^{3}$ per 100 -year time step (per meter of shoreline) from $4500 \mathrm{BP}$ to $1200 \mathrm{BP}$, then reducing to $700 \mathrm{~m}^{3}$ per 100 years from 1200 to 0 BP. These sediment inputs were based on volumetric analysis of the present-day strand plain, and assume that the only source is from the Columbia River (via littoral transport). The imposed sediment input was reduced by 50 percent (as a first guess) for the rotational-shoreface simulation on the assumption that the inner-continental shelf provided an additional sediment source.

The results show that the simulated sediment input was reduced too much for the rotational-shoreface since the strand plain prograded to only 78 percent of its present width (Figure 1b). Thus, further iterations are required with increased sediment input (but these are yet to be undertaken). Animation of the full evolution however shows that the inner-shelf becomes a net source of sediments only well into an inter-event period since, during and immediately after a seismic event, displacement of sand seaward from subaerial strangulating goes toward backfilling the sea-floor depression created by earlier shoreface deepening.

The invariant-shoreface simulation produced inner-shelf topography that is inconsistent with the present-day morphology: an unrealistic bulge (clinoform) formed in the prograding shoreface (Figure 1a). Alternative trials with invariant shoreface dimensions 
of different magnitudes failed to reduce the morphological discrepancy to any significant degree. Nevertheless, since this simulation prograded 8 percent too far, markedly larger shoreface dimensions than any tested may reduce the clinoform and redistribute some of the depositional volume further offshore, thus reducing the sub-aerial volume and extent of the barrier.

Dramatic differences between responses of invariant and rotational shorefaces emerge from the simulations of subsidence events. Subsidence-induced shoreline recession with invariant shorefaces (classic Bruun response) is proportional to the magnitude of the subsidence (i.e., sea-level rise); this response parameter is insensitive to earthquake timing (Figure 2). The opposite is the case with rotational shoreface behaviour, indicating the strongly non-linear effect of event sequencing and sensitivity to antecedent morphology (Figure 3).

The comparative severity of a future seismic-event (2-m subsidence within the next 100 years) for invariant and rotational shorefaces differ significantly (Figure 4). The conventional analysis (classic Bruun) predicts a much smaller recession than if shoreface rotation is a reality. Unfortunately for the local community, model calibration against the long-term coastal evolution suggests that shoreface rotation is more likely to be the governing behaviour. Thus the larger impact prediction should be anticipated.

\section{REFERENCES}

Atwater, B. F., and Hemphill-Haley, E. 1997. Recurrence intervals for great earthquakes of the past 3,500 years at northeastern Willipa Bay, Washington, U.S. Geological Survey Professional Paper 1576, 108 p.

Cowell, P.J., Roy, P.S., and Jones, R.A. 1995. Simulation of large-scale coastal change using a morphological behaviour model, Marine Geology, 126, pp. 45-61.

Cowell, P.J., Roy, P.S., Cleveringa, J. and de Boer, P.L. 1999. Simulating coastal systems tracts using the Shoreface-Translation Model, International Association of Sedimentologists Special Publication, Oxford, Blackwell Scientific Pub. (in press).

Woxell, L. K. 1998. Prehistoric beach accretion rates and long-term response to sediment depletion in the Columbia River littoral system, USA, M.S. Thesis, Portland State University, Portland, Oregon, 206 p. 

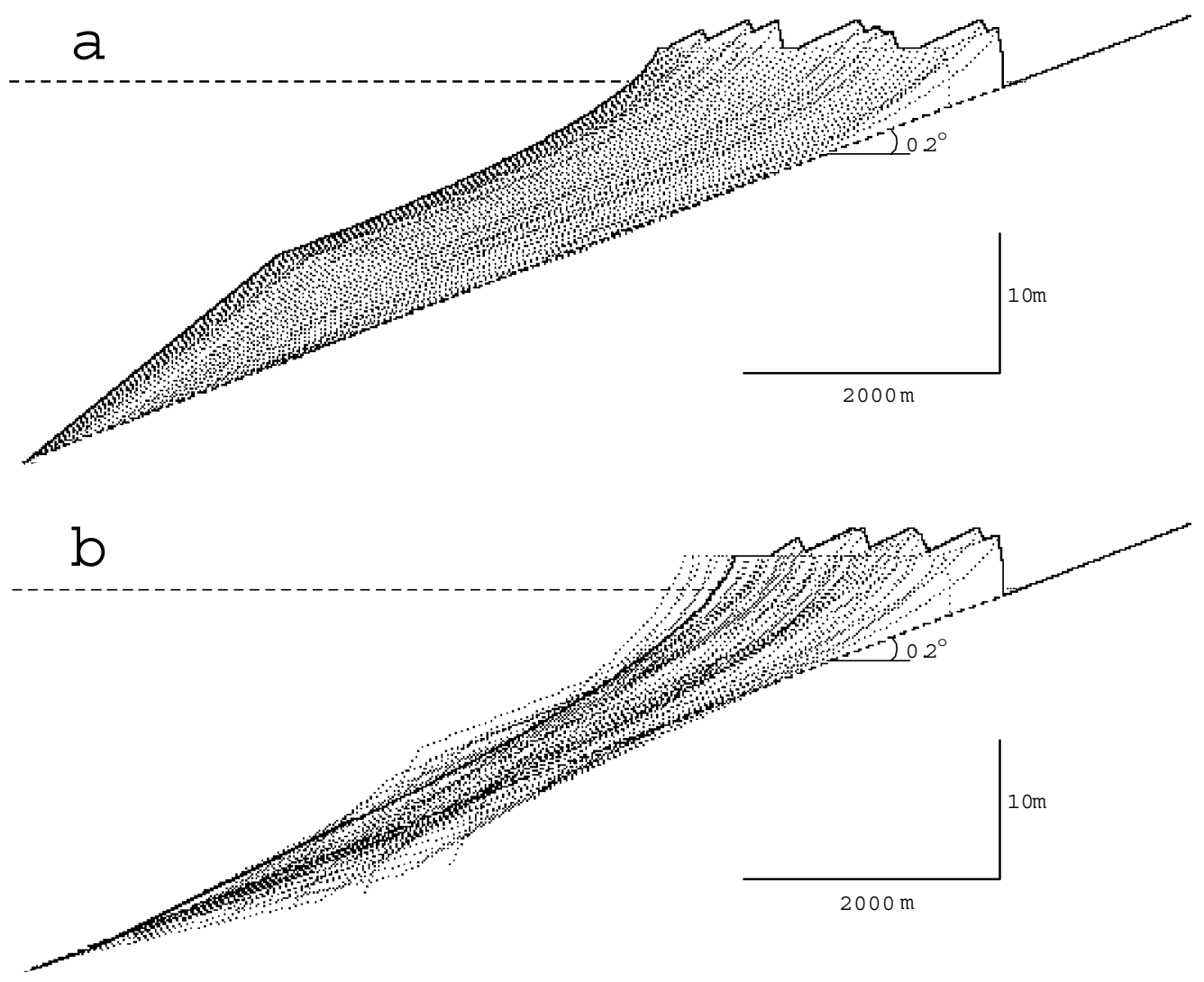

Figure 1. STM simulation of the Long Beach strand plain with a) constant shoreface dimensions $\left(h_{*}=15, L_{*}=3000, L_{o}=2000\right)$ and littoral sediment input of $1358 \mathrm{~m}^{3} \mathrm{~m}^{-1}$ per 100 year time step (reducing to $700 \mathrm{~m}^{3} \mathrm{~m}^{-1}$ after $1200 \mathrm{BP}$ ); and b) time-varying shoreface dimensions, causing shoreface rotation, and a littoral sediment input of $676 \mathrm{~m}^{3} \mathrm{~m}^{-1}$ per 100 year time step (reducing to $300 \mathrm{~m}^{3} \mathrm{~m}^{-1}$ after $1200 \mathrm{BP}$ ). 

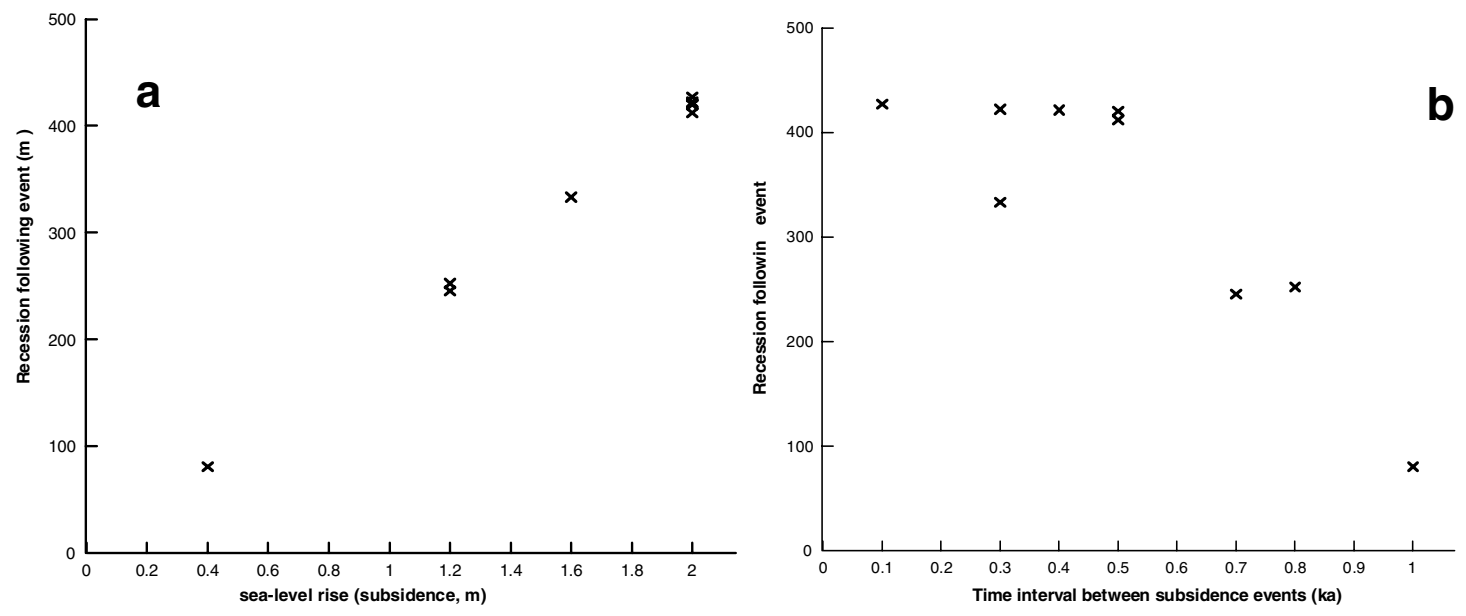

Figure 2. Recession as a function of a) subsidence, and b) the length of time between successive subsidence events, from simulation with invariant shoreface.
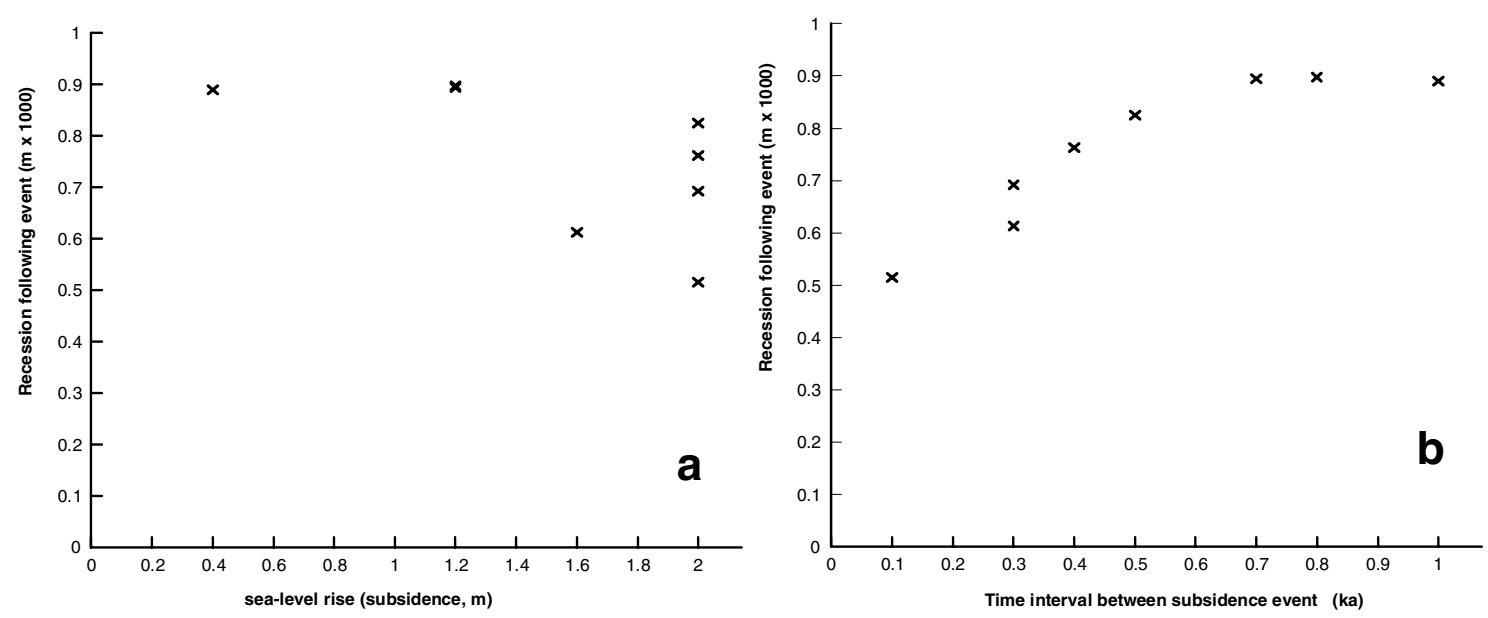

Figure 3. Recession as a function of a) subsidence, and b) the length of time between successive subsidence events, from simulation with shoreface rotation. 


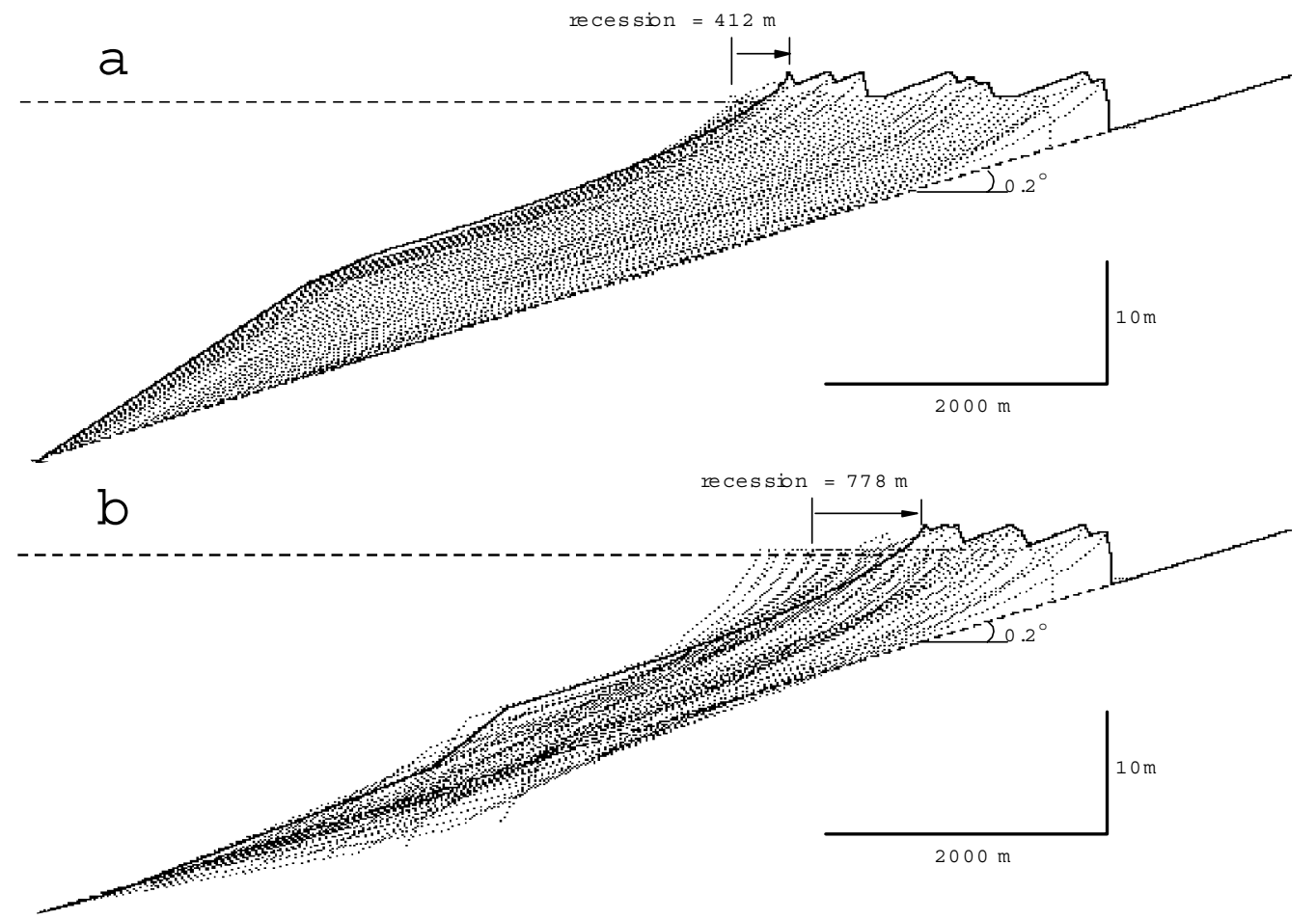

Figure 4. Simulated recession due to a future earthquake event for a) an invariant shoreface, and b) a rotational shoreface. Subsidence $=2 \mathrm{~m}$ for both cases. 


\title{
HISTORY OF SAND SEQUESTERING IN A HOLOCENE BAY-MARGIN SPIT COMPLEX, WILLAPA BAY, WASHINGTON
}

\author{
Robert Morton, U.S. Geological Survey \\ Curt Peterson, Portland State University \\ Oscar Sorenson, Portland State University \\ David Qualman, Portland State University \\ Sandy Vanderburgh, University College of the Fraser Valley
}

\begin{abstract}
The former spits of Cape Shoalwater and three parallel spits surrounded by tidal flats and marshes on the north shore of Willapa Bay (Kindred Island, Tokeland Spit, and Empire Spit, Figure 1) reflect two episodes of entrance channel migration, sediment influx and redistribution, and sand storage during the late (?) Holocene. These events document the pre-historic and historic evolution of the estuary and subsequent reorganization at both millenial and decadal time scales. Swales separating the North Cove spits are partly controlled by topographic lows and discharge associated with the network of local streams draining the nearby Pleistocene uplands.
\end{abstract}

The oldest exposed beach ridge, Kindred Island, is low $(<2 \mathrm{~m} \mathrm{msl})$, uninhabited, and serves as an anchor point for dikes that transform the surrounding marsh into grazing pasture. Tokeland Spit, the relatively large intermediate ridge, is as much as $4 \mathrm{~m}$ high, densely forested, and supports a small community of residences and businesses. Although the southeastern third of Tokeland is exposed to waves and is experiencing erosion, both Tokeland Spit and Kindred Island are stable landforms. Empire Spit is a low $(<2 \mathrm{~m})$, relatively-young, unstable feature that is covered with grasses and low shrubs. Its recent formation is related to the rapid northward migration of the entrance channel and attendant $3.8 \mathrm{~km}$ historical beach retreat at Cape Shoalwater (Terich and Levesellar, 1986; Dingler and Clifton, 1994; Kaminsky et al., 1999). The northwestern segment of Empire Spit is migrating landward as the beach retreats and sand washes over into the adjacent marsh. In contrast, the southeastern spit segment is receiving sand recently eroded from around the North Cove channel-diversion structure. Wrack lines of large trees and other debris demonstrate that all three spits and the intervening tidal flats and marshes are flooded periodically by winter storms and spring high tides during El Niño events. A recent residential development constructed in the swale between Empire and Tokeland spits was flooded in 1999.

Morphological evidence indicates that Tokeland Spit formed either before or at the same time that the deep entrance channel to Willapa Bay was pinned on the north shore and occupied what is now the North Cove marsh (Figure 1). Elevations and width of the spit suggest that it was exposed to deep-water ocean waves and overwash flooding during storms at spring high tides. Subsequent seaward and southward migration of the entrance channel, in a direction opposite to that of net longshore drift, resulted in the construction of Cape Shoalwater and a series of terminal spits recurved to the southeast. During this 
period of maximum southerly channel migration, Tokeland Spit was protected from direct wave attack. Large volumes of sand were deposited at Cape Shoalwater when oceanographic conditions favored southerly sand transport. This required changes in the physical processes (net longshore currents and wave directions), not just changes in sand supply. The large-scale lateral channel migration and spit construction probably were concurrent with regional beach-ridge progradation on Long Beach Peninsula and the Grayland Plains.

A field reconnaissance of Kindred Island (Figure 1) shows that the surface is characterized by low $(<1 \mathrm{~m})$ hummocky sand mounds that appear to be eolian deposits. Shallow trenches reveal that the modern soil and associated sediments overlie a paleosol at depths ranging from 30 to $70 \mathrm{~cm}$ below the irregular surface. A radiocarbon date for charcoal collected at a depth of $52 \mathrm{~cm}$ from the central part of the island (560 $\pm 30 \mathrm{yr}$ BP) seems exceptionally young, and it may represent the timing of plant growth on a much older surface that predates eolian deposition. A sand sample from the same trench at $90 \mathrm{~cm}$, which was intended to determine when the spit core was deposited, was dated at $17.8 \pm 4 \mathrm{ka}$ using thermoluminescence dating techniques. This date may be too old for a beach deposit considering that global sea level was at a maximum lowstand $(-100 \mathrm{~m})$ at that time. It is possible that sediment composing the core of Kindred Island was derived from the nearby Pleistocene outcrops, and the short transport distance and exposure time may have prevented the quartz from being reset to zero. Also the quartz content in the sample was diluted by the high concentration of heavy minerals, which could also make the date unreliable.

Stratigraphic sections (vibracores) and additional dates from all three spits will be necessary: (1) to determine the periods of optimum sediment transport and storage, (2) to differentiate the sediment contributions from local upland (Pleistocene) sea-cliff erosion and beach or offshore sources, (3) to reconstruct the late Holocene paleogeography of Willapa Bay, and (4) to correlate events of shoreline progradation and eolian deposition around the bay. Key questions to be answered relate to the timing and conditions that cause large-scale lateral migration of the entrance channel, sediment redistribution at the mouth of the bay, and transfer of sand to tidal flats within the bay. Some unanswered questions are: (1) What are the conditions that favor net southerly transport and deposition of sand at the entrance to Willapa Bay, and (2) have threshold conditions been surpassed so that the previous northerly limit of erosion at North Cove will be exceeded?

\section{REFERENCES}

Dingler, J. R., and Clifton, H. E. 1994. Barrier systems of California, Oregon, and Washington, In: Davis, R. A., ed., Geology of Holocene Barrier Islands, SpringerVerlag, Berlin, pp. 115-165.

Kaminsky, G. M., Daniels, R. C., Huxford, R., McCandless D., and Ruggiero, P. 1999. Mapping erosion hazard areas in Pacific County, Washington, Journal of Coastal Research, Special Issue 28, pp. 158-170. 
Terich, T., and Leveseller, T. 1986. The severe erosion of Cape Shoalwater, Washington, Journal of Coastal Research, 2, pp. 465-477.

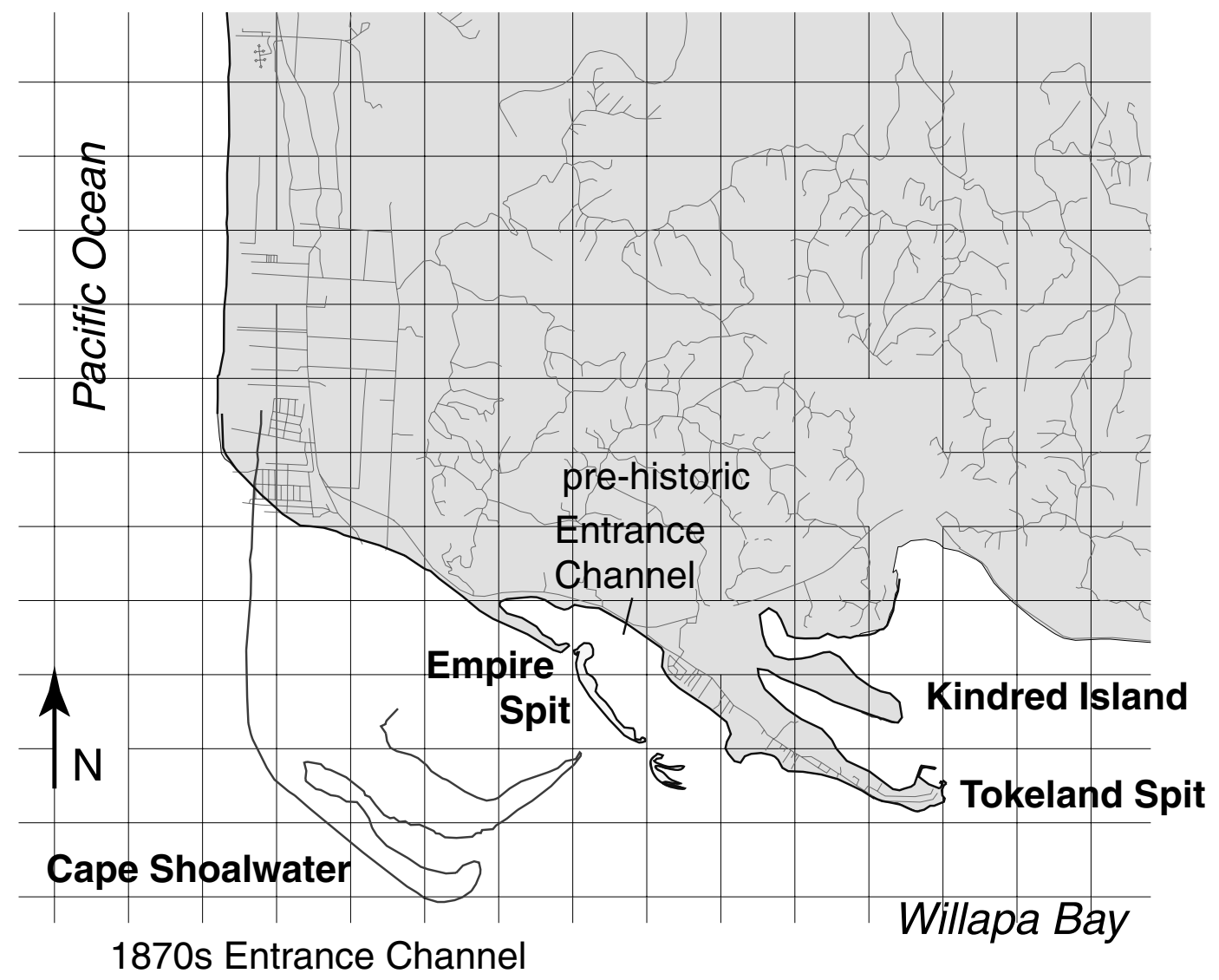

Figure 1. Pre-historic and historic positions of sand spits and the entrance channel to Willapa Bay. Two episodes of sand accumulation and channel migration are inferred from the patterns of deposition and erosion. The southeastern end of Kindred Island is the general location of shallow trenches that were sampled for radiocarbon and thermoluminescent dates. 


\title{
PRELIMINARY RESULTS AND INTERPRETATIONS OF THE LATE- HOLOCENE SEDIMENT FILL OF WILLAPA BAY AND GRAYS HARBOR, WASHINGTON
}

\author{
Sandy Vanderburgh, University College of the Fraser Valley \\ Curt Peterson, Portland State University \\ Robert Morton, U.S. Geological Survey \\ Jim Phipps, Grays Harbor College \\ David Qualman, Portland State University \\ Oscar Sorsenson, Portland State University
}

\begin{abstract}
Late-Holocene sediments in the tidally-dominated Pacific Northwest bays of Willapa Bay and Grays Harbor are preserved as tidal flat sand and mud, interbedded accretionary bank sand/mud couplets, and shallow channel bottom sand. To fully understand netsedimentation rates and the complex processes in these bays, vibracores were collected from representative tidal flats, accretionary banks, and shallow tidal channels. During the summer of 1999 a total of 56 vibracores were collected, 35 in Willapa Bay and 21 in Grays Harbor. Penetration depths generally ranged from $3-5 \mathrm{~m}$. Coring was accomplished using local oyster dredges in the open bays, a zodiac for open bay mud flats and accretionary banks, and a quad with trailer for shoreline sand and mud flats. All cores were logged in the field (now stored at PSU) and samples were taken for grain size analysis, mineralogy, and age dating.
\end{abstract}

Three depositional environments were sampled, and they all exhibited fining upward cycles that tended to become thinner-bedded upsection. Specifically, the $25-75 \mathrm{~cm}$ thick tidal flat sequences show a gradation from fine sand or muddy sand to bioturbated, organic rich mud. Accretionary bank sequences range from 50-100 cm thick and fine upwards from cross-bedded sand or sand-mud couplets to bioturbated mud. Numerous cores exhibited fining upward sequences that often terminated in organic rich, oxidized marsh sediments. In Willapa Bay, at least 10 gradational sequences were observed in one $4 \mathrm{~m}$ deep core (below MLLW). These repetitive gradational sequences may be indicative of coseismic subsidence events.

Some unanticipated findings of active bay-fill processes included the observation of: 1) the tectonic signatures of 1-2 m coseismic subsidence events associated with Cascadia megathrust earthquakes, 2) sand transport from channel axes to tidal flats along point bar surfaces, (3) active erosion-transport of subaerial sand shoals in recent historic time in Grays Harbor, (4) bayward transport and deposition of sand removed from the 1998 channel stabilization project at Washaway Beach, and (5) extensive bioturbation of tidal flat mud by gray whales (Grays Harbor) and ghost shrimp (Willapa Bay).

Early conclusions arising from this study suggest that: (1) modern sand dominated tidalflats along bay shorelines are anomalous in the geologic record and (2) episodic tidal flat 
subsidence is recorded in buried root horizons, as up-core reductions in sand laminae of sand/mud couplets, or as fining upward trends. Additional coseismic features include possible tsunami pebble layers, fluidized dike and sill intrusions, and debris flow deposits. These lower-intertidal and subtidal sedimentary cycles created by coseismic subsidence events leave a distinctive signature in the sedimentary record and are a process unique to these Pacific Northwest bays. 


\title{
PRESENTING GEOLOGIC DATA IN A WEB-BASED GIS
}

\author{
David Percy, Portland State University
}

\section{ABSTRACT}

Very diverse sets of geologic data have been collected by the investigators responsible for the geologic "framework" components of the Southwest Washington Coastal Erosion Study. The need to integrate these data sets has led to a web-based approach for disseminating the data among the investigators. Offshore seismic profiles, groundpenetrating radar records, auger core logs, sediment sample analyses, sea-level curves and interpretive geologic cross-sections are being made available to the investigators via a common web server and individual desktop web-browsers. We use an interactive WWW (world wide web, or web) GIS (geographical information system) program, linked to the data sets, to allow the user to access the map and relational data. This provides a similar functionality to that which they would have in a GIS program such as ArcView. However, the user does not require software and experience with ArcView. Furthermore, any operating system platform can be used so long as a modern (4+) browser is available to the operating system. The web-based approach to sharing the data sets removes the need for an "on-call" GIS manager at each institution to process the data requested by the different investigators. The data requests are handled automatically by a common server (USGS computer) currently located in the Geodata Clearinghouse at Portland State University. However, the location of the server or servers is not limited to any specific site. The webGIS application is written in Visual Basic linked via the ESRI ActiveX component MapObjects to shapefiles and JPEG graphics files stored on the server. A dynamic link library (DLL) on the web server sends requests to the application. The application processes requests from the user such as zoom, identify or hyperlink and sends back the data requested. This keeps the CPU load balanced toward the server, and minimizes bandwidth across the Internet.

Other approaches, such as ArcView IMS, or ArcExplorer, are easier to implement from a programming standpoint but, they were rejected either because of stability, speed, flexibility or cross-platform considerations. Some tend to be considerably less responsive, i.e., slower, and GIS manager dependent. This is because these send entire data sets to the off-site computer, rather than selecting the appropriate data subsets. These "canned" approaches are also less flexible or "customizable" than the web-GIS program now under use. We have found that whereas there is more programming overhead associated with the current approach, the payoff in responsiveness and customization to the user is well worth the extra effort. Of future importance, the web approach allows for the capability to tie into other "non-GIS" databases. Such links will permit queries to be submitted by off-site users and responses to be returned in real time, i.e., search engine development. A reach beyond our own data sets will also be possible with our forthcoming status as a node on the NSDI Clearinghouse Network. 
Future work should include development of a project-wide database, corresponding search engines, and access level permissions. Eventually, GIS-products from the project can be developed and distributed directly to the public via off-site web-browsers, as part of the public outreach and education component of the study. Other products to derive from this effort could be decision support tools for public policy makers. This would include a raster-based analysis tool, where the user would assign relative weights to different coverages, and then get visual feedback on the results. In this way the user could play with different scenarios to begin to understand the complexity of the system.

\section{ACKNOWLEDGEMENTS}

This project benefited greatly from the initial software development of Kenneth M. Cruikshank, and the patient, but persistent feedback from VeeAnn Cross and Dave Twichell.

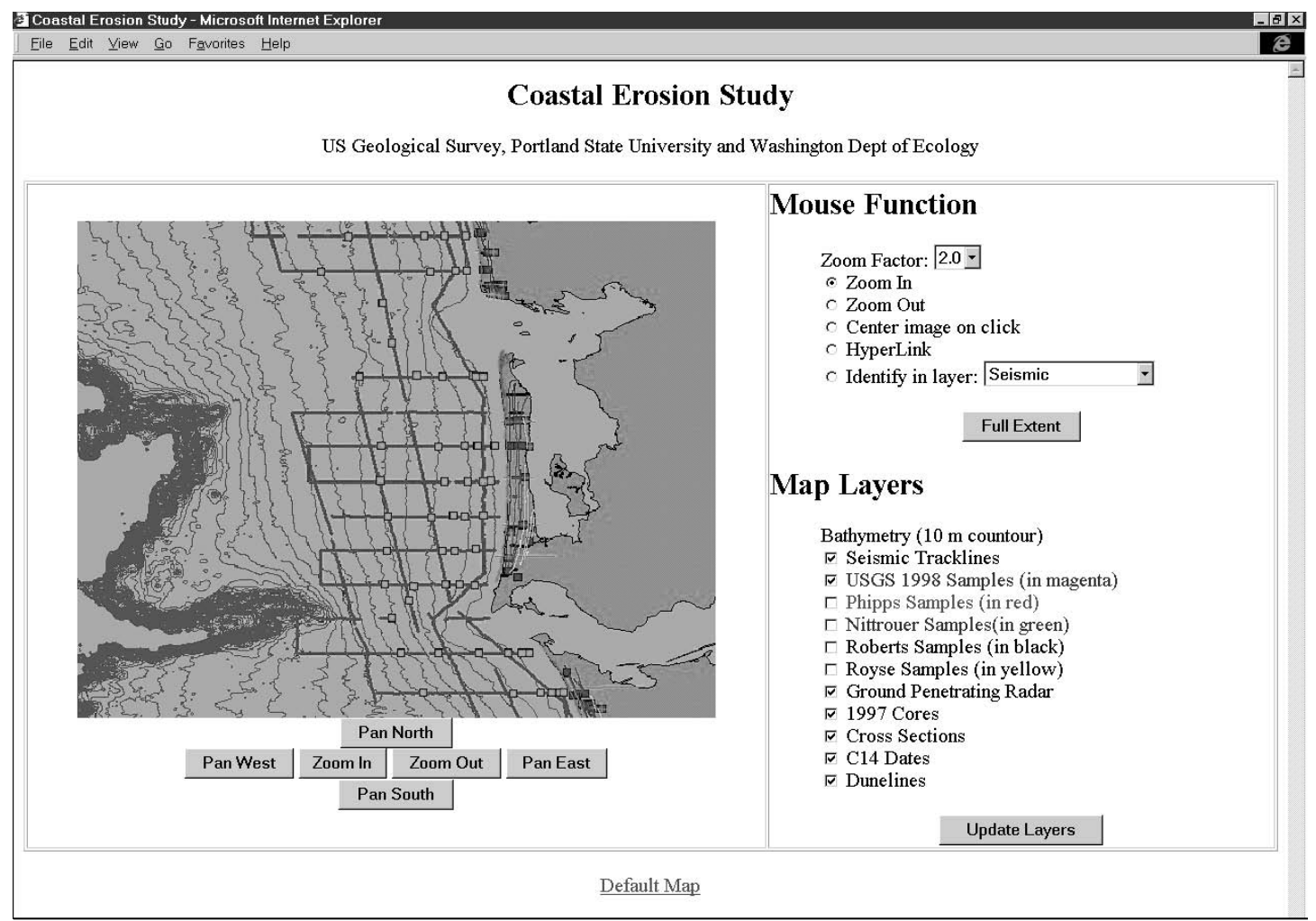

Figure 1. Screen shot of web-GIS. Layers are turned on and off with checkboxes. The mouse can be used to change scale (Zoom), change the center point (Pan), query the data (Identify), or show a picture (Hyperlink). 


\title{
MORPHOSTRATIGRAPHIC AND CHRONOLOGIC SIMILARITIES OF LATE HOLOCENE DEPOSITION ON THREE US COASTS, RESOLVING TECTONIC, EUSTATIC, AND CLIMATIC INFLUENCES
}

\author{
Robert A. Morton, U.S. Geological Survey
}

\begin{abstract}
Middle to late Holocene styles of deposition on the Southeast Atlantic, northern Gulf of Mexico, and Pacific Northwest coasts are remarkably similar. However, the similar patterns and timing of deposition are attributed to fundamentally different processes. Thin depositional cycles of rapid flooding and gradual shoaling, and sets of progradational beach ridges with intervening scarps have been interpreted as products of: (1) abundant sediment supply under rapidly decelerating and stable sea-level conditions, (2) fluctuating sea levels that were higher than present and then progressively fell, and (3) co-seismic subsidence and interseismic uplift.
\end{abstract}

In South Carolina (Stapor and Mathews, 1983; Colquhoun and Brooks, 1986) and Georgia (DePratter and Howard, 1981), the middle to late Holocene sea-level history was characterized by high-frequency oscillations superimposed on submergence. Major events included transgressive flooding and barrier initiation about 4 ka that was followed by minor sea-level fluctuations and attendant beach-ridge progradation (Hayes, 1994). The south coast of Florida is assumed to be tectonically stable because the underlying carbonates are thick and consolidated. However, even tectonic stability does not eliminate conflicting histories. Sea-level curves constructed from ages of subtidal basal peats (Scholl, 1964; Parkinson, 1989) indicate a continuous gradual rise in sea level (submergence) with progressively diminishing rates. In contrast, curves constructed using ages of shells from beach ridges indicate that sea level was both higher and lower than present during the past $3 \mathrm{ka}$ (Stapor et al., 1991). C14 dates of peats and shells from the chenier plain of the Mississippi delta (Frazier, 1974; McFarlan, 1961), provide a basis for constraining relative sea-level changes in the northern Gulf of Mexico. Variable rates of subsidence are calculated if sea level is kept constant for the past $4 \mathrm{ky}$. Alternatively, by holding subsidence rates constant, a reconstructed curve shows that sea level may have been slightly higher than present about 3-5 ka. Dates and elevations of open-ocean and interior-bay features in the western Gulf support the interpretation that sea levels were higher than present and they oscillated during the past 3-5 ka (Morton et al., in press). In southwest Washington, subtidal flooding and shoaling events, and beach-ridge scarps are attributed to earthquake induced subsidence and subsequent tectonic uplift (Atwater, 1987; Darienzo and Peterson, 1990; Meyers et al., 1996).

Stratigraphic studies from all three coasts indicate that (1) mainland scarp and sea-cliff erosion predates about $4 \mathrm{ka}$, and (2) about $3.5 \mathrm{ka}$ coastal depositional responses reversed from transgressive to regressive conditions that resulted in widespread beach-ridge progradation. Within most of the beach-ridge sets are low scarps and unconformities, attesting to shoreline realignment caused by water-level fluctuations. The origin of the 
erosional events is controversial. Hydro-isostatic adjustments to glacial melting and crustal unloading make the relative sea-level histories unique at different near-field and far-field sites. Except for glaciated coasts, the eustatic changes during the Holocene should be recorded in the coastal stratigraphic sequences. Late Holocene paleotemperatures reconstructed from ice cores in Greenland (Dahl-Jensen et al., 1998), and estimates of ice-sheet volumes in the Antarctic (Goodwin, 1998) provide evidence that atmospheric temperatures cooled, ocean volume decreased, and sea level fell about $1 \mathrm{~m}$ between 4 and $2.5 \mathrm{ka}$.

\section{REFERENCES}

Atwater, B. F. 1987. Evidence for great Holocene earthquakes along the outer coast of Washington State, Science, 236, pp. 942-944.

Colquhoun, D. J., and Brooks, M. J. 1986. New evidence from the southeastern United States for eustatic components in late Holocene sea levels, Geoarcheology, 3, pp. 275-291.

Dahl-Jensen, D., Mosegaard, K., Gundestrup, N., Clow, G.D., Johnsen, S.J., Hansen, A.W., and Balling, N. 1998. Past temperatures directly from the Greenland ice sheet, Science, 282, pp. 268-271.

Darienzo, M. E., and Peterson, C. D. 1990. Episodic tectonic subsidence of Late Holocene salt marshes, northern Oregon central Cascadia margin, Tectonics, 9, pp. 1-22.

DePratter, C. B., and Howard, J. D. 1981. Evidence for a sea-level lowstand between 4500 and 2400 years BP on the southeast coast of the United States, Journal of Sedimentary Petrology, 51, pp. 1287-1295.

Frazier, D.E. 1974. Depositional episodes: their relationship to the Quaternary stratigraphic framework in the northwestern portion of the Gulf basin, Austin, University of Texas, Bureau of Economic Geology, Geological Circular, 74-1, $28 \mathrm{p}$.

Goodwin, I.D. 1998. Did changes in Antarctic ice volume influence late Holocene sea level lowering? Quaternary Science Review, 17, pp. 319-332.

McFarlan, E. Jr. 1961. Radiocarbon dating of Late Quaternary deposits, South Louisiana, Geological Society of America Bulletin, 72, pp. 129-158.

Meyers, R. A., Smith, D. G., Jol, H. M., and Peterson, C. D. 1996. Evidence for eight great earthquake-subsidence events detected with ground-penetrating radar, Willapa Barrier, Washington, Geology, 24, pp. 99-102. 
Morton, R. A., Paine, J. G., and Blum, M. D. 2000. Responses of stable bay-margin and barrier-island systems to Holocene sea-level highstands, western Gulf of Mexico, Journal of Sedimentary Research, 70, in press.

Parkinson, R.W., 1989. Decelerating Holocene sea-level rise and its influence on southwest Florida coastal evolution - a transgressive/regressive stratigraphy, Journal of Sedimentary Petrology, 59, pp. 960-972.

Scholl, D. W. 1964. Recent sedimentary record in mangrove swamps and its rise of sea level over the southwestern coast of Florida: Part 1, Marine Geology, 1, pp. 344-366.

Stapor, F. W., and Mathews, T. D. 1983. Higher than present Holocene sea-level events recorded in wave-cut terraces and scarps: Old Island, Beaufort County, South Carolina, Marine Geology, 52, pp. M53-M60.

Stapor, F.W., Mathews, T.D., and Lindfors-Kearns, F.E. 1991. Barrier-island progradation and Holocene sea-level history in southwest Florida, Journal of Coastal Research, 7, pp. 815-838. 


\title{
HISTORICAL EVOLUTION OF THE COLUMBIA RIVER LITTORAL CELL BARRIERS
}

\author{
George Kaminsky, Washington Department of Ecology
}

\section{INTRODUCTION}

This abstract is based on Kaminsky et al., 1999. It summarizes a synthesis of geological observations, morphodynamic changes, and processes modeling to explain the historical coastal evolution of the Columbia River littoral cell. The synthesis draws from analyses of historical shoreline and bathymetric changes, and subsurface stratigraphy. The spatial and temporal scales of change caused by both natural and human influences are quantified and compared. The results indicate that the Columbia River littoral cell is a highly dynamic coastal system that naturally evolves in response to large magnitude episodic events as well as frequent high energy forcing conditions. Human impacts, and particularly the installation of jetties at the entrances to the Columbia River and Grays Harbor during the early 1900s, have dramatically influenced the evolution of the littoral cell. The integration of diverse data sets and the synthesis of their analyses enable the development of conceptual models and predictive capabilities of the coastal evolution of the Columbia River littoral cell.

\section{HISTORICAL EVOLUTION OF THE CRLC}

The U.S. Coast \& Geodetic Survey topographic surveys (NOS T-Sheets) of 1868 mark the beginning of the historical period for reliable data in the Columbia River littoral cell. Previous maps and topographic surveys since the late 1700s lack adequate control for use in quantitative change analysis. However, through geological investigations, a wellconstrained 1700 shoreline position (erosion scarp) from an earthquake-induced subsidence event has been mapped (Woxell, 1998; Peterson et al., 1999). This time line allows for the comparison of change over the historical period with the recent prehistoric period to obtain a quantitative assessment of coastal evolution. Over the historical period, shoreline progradation rates are typically an order of magnitude greater, and are up to two orders of magnitude greater along reaches adjacent to the estuary entrances. In addition, the historical shoreline change rates have much larger alongshore gradients over the length of the sub-cells.

In each of the sub-cells, the coastal plains accreted rapidly within a few decades of jetty construction at the entrances to the Columbia River and Grays Harbor in the early 1900s. Clatsop Spit accreted over $7 \mathrm{~km}^{2}$ of land within $5 \mathrm{~km}$ of the Columbia River South Jetty, and shoreline progradation rates typically jumped from $0.5 \mathrm{~m} / \mathrm{yr}$ to $5 \mathrm{~m} / \mathrm{yr}$ or more along the Clatsop Plains sub-cell. North of the Columbia River, a pocket beach quickly developed, accreting nearly $4 \mathrm{~km}^{2}$ of land between the Columbia River North Jetty and North Head, $3.5 \mathrm{~km}$ to the north. In stark contrast to the shoreline progradation rates of $0.1 \mathrm{~m} / \mathrm{yr}$ or less between 1700 and the $1870 \mathrm{~s}$, the southern half of Long Beach Peninsula experienced a major accretionary period, prograding at rates of 4-6 m/yr. Along the 
Grayland Plains, shoreline progradation rates jumped from $1.2 \mathrm{~m} / \mathrm{yr}$ to $5 \mathrm{~m} / \mathrm{yr}$. The North Beach sub-cell prograded rapidly along its southern end, accreting approximately $8 \mathrm{~km}^{2}$ of land within $6 \mathrm{~km}$ of the Grays Harbor North Jetty, with decreasing rates of accretion over tens of kilometers toward Point Grenville.

The sediment accumulation rates over the historical period along the littoral cell reveal higher accumulation rates during the early historical period compared to the period since the 1950s. The largest differences in accumulation rates between the periods are generally closest to the estuary entrances. Prior to the jetty installation, ebb-tidal currents are assumed to have been in equilibrium with existing wave forcing and sediment budget, resulting in broad, shallow ebb-tidal deltas extending on the order of $5 \mathrm{~km}$ seaward from the shoreline of the estuary entrances. The jetties at both the Columbia River and Grays Harbor were built on these shallow delta plains to constrict the inlet flow and scour the entrance channel for navigation purposes. Over the course of several decades, the increased ebb-tidal flows pushed the center of the deltas farther offshore, and waves forced large volumes of sediment onshore from the flanks of the ebb-tidal deltas, where tidal inlet currents were no longer present.

The post-jetty historical shoreline change rates show a highly dynamic shoreline with kilometer scale variability, nonlinear long-term trends, and trend reversals as shown in Figures 1 and 2. It is evident that the jetties have influenced accretion and possibly erosion patterns on the beaches over distances of tens of kilometers. It is also apparent that accretion rates along the entire littoral cell have generally slowed since the 1926 1950s period. During the most recent period, high erosion rates occur adjacent to the jetties, where the beaches had previously accreted most rapidly. Through time, all of these erosion sites have either increasing erosion rates or an expanding spatial scale of erosion along the shoreline or both.

These large scale coastal change patterns and the accumulation of sediment can not be explained by a simple model of longshore sediment transport accumulating against an imposed boundary. For example, along the southern Long Beach Peninsula, both geologic data and wave refraction modeling suggest a dominant net northward flux of sediment. The sediment accumulation adjacent to the jetties over the historical period does not merely represent the trapping of sediment by the jetties, but rather sediment transport from its ebb-tidal delta source. Preliminary modeling results in each sub-cell indicate that the areas near the jetties tend to have the highest sediment-transport rates.

\section{Summary of Historical Observations}

The changes in shoreline progradation rates that have occurred throughout the littoral cell are coupled with equally striking reversals in shoreline change trends. The installation of jetties resulted in sediment accumulation on the coastal plains supplied in part by erosion of the extensive tidal inlet shoals. Within the past few decades, the areas adjacent to the jetties have experienced chronic erosion conditions. Presently the ebb-tidal deltas of Grays Harbor and the Columbia River appear to be essentially decoupled from the littoral zone. The overall changes in shoreline orientation and inlet morphology, and the deepening of the adjacent shorefaces appears to have significantly affected the distribution 
of Columbia River sediment throughout the littoral cell. The modern sediment pathways, fluxes, and compartment volumes that comprise the littoral cell sediment budget may in fact be quite different from that of the late Holocene.

\section{SHORELINE CHANGE MODELING}

Among the most challenging tasks in the study is the development of a predictive capability of coastal change. It remains difficult to determine whether the estuary entrances, ebb-tidal deltas, and adjacent shorelines of Grays Harbor and the Columbia River are approaching an equilibrium condition from the jetty-induced perturbations of the early 1900s. In addition, the ongoing changes in Columbia River sediment supply and other factors such as climate change or relative sea-level change, may be independently influencing the behaviour of the shoreline. Since both the late prehistoric and early historical periods show shoreline behaviour patterns that differ significantly from the present trends, it is especially important to have an understanding of the mechanisms and influences driving coastal change. A simple extrapolation of historical shoreline change trends in this region could potentially be wrong in both magnitude and direction. A more detailed investigation of historical shoreline change and more sophisticated techniques for predicting future shoreline position are therefore warranted.

A major question to evaluate is whether recent regional-scale shoreline change rates indicate a long-term trend of slowing shoreline progradation that may manifest as a future erosion trend or if the shoreline is adjusting to a dynamically stable position. Various modeling tools are being applied to simulate the long-term morphologic change and quantitatively evaluate conceptual models. The initial efforts are derived from the model formulation and implementation process that allows testing of hypotheses and diagnosing trends, patterns and variability in the system response to different input conditions. The optimized output results may be preliminary, but they can be refined as additional data and knowledge are obtained and other approaches are applied.

\section{SUMMARY}

The Columbia River littoral cell functions as a large-scale morphodynamic system with controlling variables such as sediment supply, regional tectonics, climatic forcing, and especially human intervention. There are a number of significant results and observations that can be synthesized to present a coherent understanding of the behaviour of the Columbia River littoral cell. The diversity of data sets and the multi-scale systems approach taken in the study has enabled the development of a conceptual working model to be refined through continued data collection, analyses, integration, and modeling applications. The application and integration of modeling approaches including both top down geological-based models and bottom up process-based models should advance capabilities for predicting management scale coastal evolution. 


\section{REFERENCES}

Gelfenbaum, G., Sherwood, C. R., Peterson, C. D., Kaminsky, G., Buijsman, M., Twichell, D., Ruggiero, P., Gibbs, A., and Reed, C. 1999. The Columbia River littoral cell: A sediment budget overview, Proceedings of Coastal Sediments '99, ASCE, pp. 1660-1675.

Gibbs, A., and Gelfenbaum, G. 1999. Bathymetric change off the Washington-Oregon Coast, Proceedings of Coastal Sediments '99, ASCE, pp. 1627-1642.

Kaminsky, G.M., Buijsman, M.C., Gelfenbaum, G., Ruggiero, P., Jol, H.M., Gibbs, A.E., and Peterson, C.D. 1999. Synthesizing geological observations and processesresponse data for modeling coastal change at management scale, Proceedings of Coastal Sediments '99, ASCE, pp. 1708-1723.

Peterson, C.D., Gelfenbaum, G., Jol, H.M., Phipps, J.B., Reckendorf, F., Twichell, D.C., Vanderburgh, S., and Woxell, L. 1999. Great earthquakes, abundant sand, and high wave energy in the Columbia cell, USA, Proceedings of Coastal Sediments '99, ASCE, pp. 1676-1691.

Ruggiero, P., Côté, J., Kaminsky, G., and Gelfenbaum, G. 1999. Scales of variability along the Columbia River littoral cell, Proceedings of Coastal Sediments '99, ASCE, pp. 1692-1707.

Woxell, L. K. 1998. Prehistoric beach accretion rates and long-term response to sediment depletion in the Columbia River littoral system, USA, M.S. Thesis, Portland State University, Portland, Oregon, 206 p. 


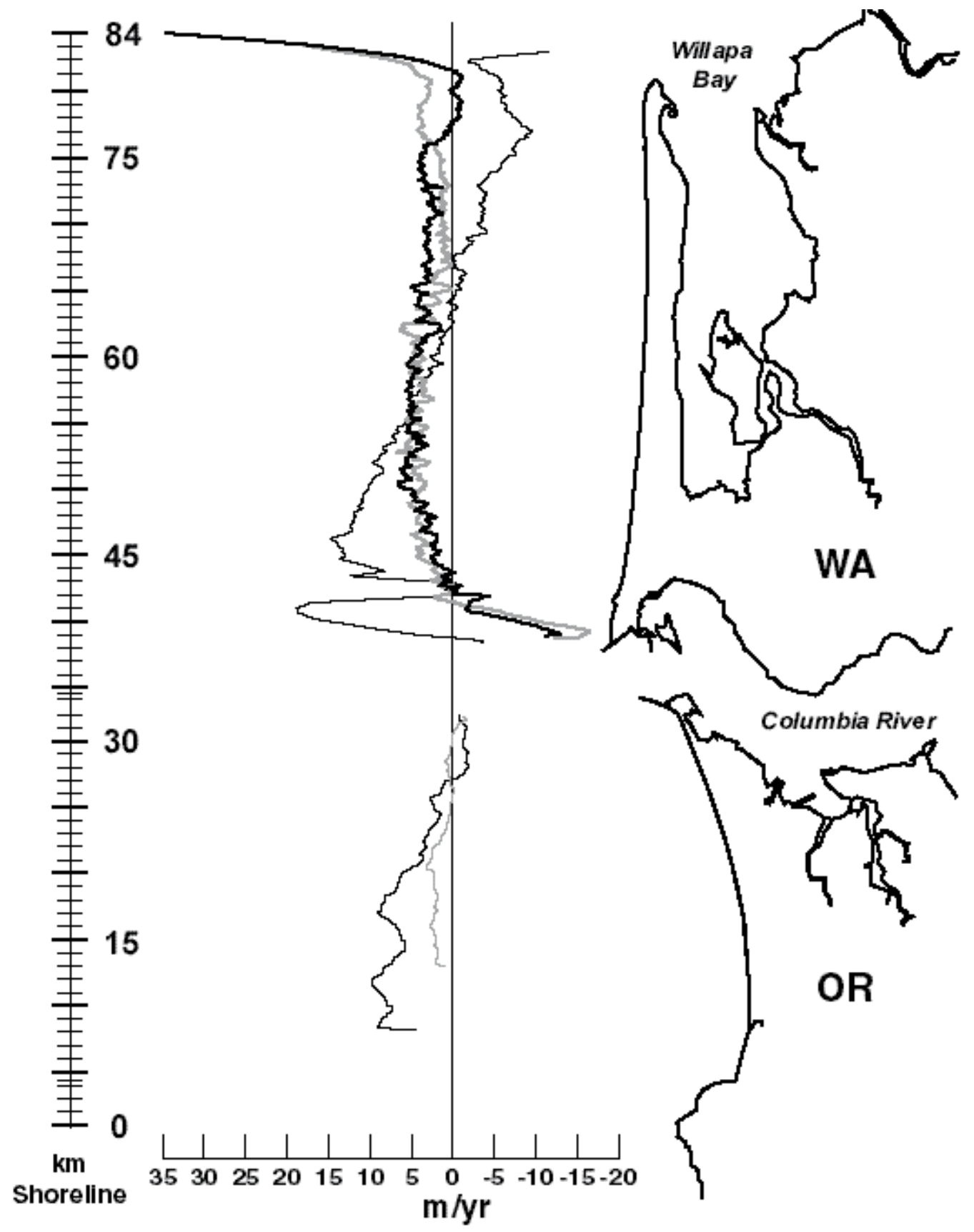

$\curvearrowright 1920 s-1950 s / 1950 s-1974 \frown 1974-1995 \frown 1950 s-1995$

Figure 1. Historical shoreline change rates in the Clatsop Plains and Long Beach sub-cells. 


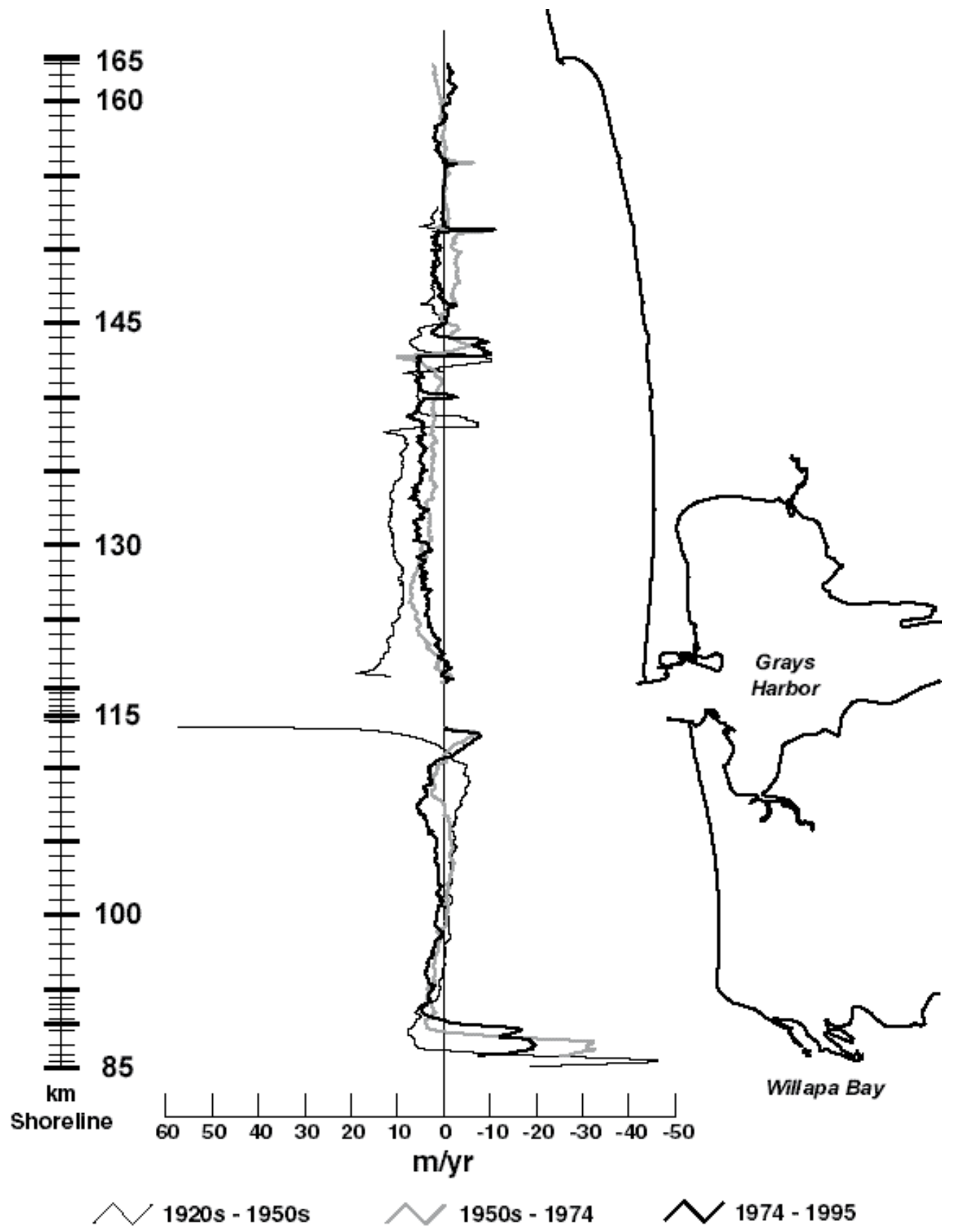

Figure 2. Historical shoreline change rates in the Grayland Plains and North Beach subcells. 


\section{INTERPRETATION OF THE AVERAGE HIGH WATER LINE FROM AERIAL PHOTOGRAPHY: VARIABILITY AND REPEATABILITY}

Richard C. Daniels, Washington Department of Ecology

Peter Ruggiero, Washington Department of Ecology

Diana McCandless, Washington Department of Ecology

\section{INTRODUCTION}

Detailed shoreline change analyses are being conducted in support of the Southwest Washington Coastal Erosion Study. These analyses are dependent on shorelines derived from historical maps, orthophotography, GPS ground survey, and airborne Light Detection and Ranging (LIDAR) data. Each of these methods may be used to estimate the location of the Average High Water Line (AHWL). The AHWL is a horizontal reference line that represents the mean landward excursion of wave run-up resulting from the most recent high tides.

The AHWL may be mapped in several different ways. For example, the National Ocean Service (NOS) used ground surveys to derive a Mean High Water Line (MHWL) for their 1880-era and 1926-era topographic sheets (T-Sheet) and aerial photography for their 1950-era T-sheets. The Department of Ecology digitized shorelines from orthophotos using visual queues that are equivalent to those used by NOS (Shalowitz, 1964). To confirm this assertion, tests were conducted in 1998 in which four aerial photos used for a 1950-era NOS T-Sheet were obtained, scanned, and orthorectified by Ecology. The AHWL was digitized from these orthophotos and compared to the 1950-era NOS MHWL. The digitized AHWL was found to coincide with the NOS MHWL. The two lines were, on average, within $\pm 10 \mathrm{~m}$ of each other.

This initial attempt at determining the homogeneity of the AHWLs used in this study highlighted the need for a detailed shoreline extraction, a shoreline repeatability, and a shoreline variability experiment. This paper describes the results from these three analyses. Results from this work provide the basic information required to develop detailed error budgets for the shorelines derived by the Study.

\section{Shoreline Extraction}

NOS T-Sheets are the only readily available data source to obtain information on shoreline position prior to 1950 (i.e., the advent of organized regional aerial photo missions by state and federal government agencies). T-sheets are detailed records of surveys that were conducted to provide shorelines for use on navigation charts issued by NOS (formerly the U.S. Coast and Geodetic Survey, CGS). The National Oceanic and Atmospheric Administration (NOAA) has recently undertaken a data rescue project to convert the historical T-sheets from paper to a digital format. NOAA has partnered with several state agencies across the nation to assist in extracting the line work and assigning attribute information from the raster images into vector data sets (NOS, 1999). 
As the coastal zone management agency for the state of Washington, the Department of Ecology has undertaken the task of digitizing shorelines for Washington and the northwest coast of Oregon from the raster images and saving them into digital vector files. To allow for the quantitative analysis of shoreline change, it is essential that the accuracy of the processes used to extract the shorelines from the historical T-sheets be determined.

A detailed accuracy assessment was conducted on the methods used to extract the NOS MHWL from the T-Sheets. The results of this analysis are described in detail in Daniels and Huxford (1999). In summary, the analysis determined:

1) the original T-sheets are accurate in their depiction of the shoreline that existed at the time of the surveys (Shalowitz, 1964). The average accuracy for the 1:20,000 scale Tsheets is twice as accurate as current USGS 1:24,000 scale topographic maps.

2) the methods used by NOS to scan the T-sheets are sound and induced no identifiable error into the raster images.

3) shrinkage or warping of the original paper T-sheets was corrected by the registration and rectification process;

4) the vectorization process used is accurate to within half the width of a line, $0.79 \mathrm{~m}$ with a 1/32 inch line on a 1:20,000 scale map (Huxford and Daniels, 1998); and

5) the NOS survey marks can be effectively used to verify the accuracy of the digital data produced by the data rescue project.

The vector data obtained from the 1950-era T-sheets meets published NOS accuracy standards for the original data source $[ \pm 3 \mathrm{~m}$ for 1:10,000 T-sheet and $\pm 6 \mathrm{~m}$ for 1:20,000 Tsheets]. The 1926/27-era T-sheets are slightly less accurate, yet on average still meet the 1950-era accuracy standards. A majority of the error in the 1926/27 T-sheets may be associated with the datum transformation process (i.e., between the North American Datum, the North American Datum of 1927, and the North American Datum of 1983).

Examination of the reconnaissance surveys and charts produced by NOS prior to the North American Datum found that the older maps (1880 era) have rotational errors ranging from $-0.84^{\circ}$ (skewed counter clockwise) to $+0.25^{\circ}$ (clockwise). These errors are not uniform over time or space. It is believed these deflections in magnetic north may be due to magnetic anomalies within the region that were not corrected for during these initial reconnaissance surveys. Other possibilities include the "less stringent" astronomical observation methods used to calculate magnetic variation for reconnaissance surveys (Shalowitz, 1964), or distortion caused by the conversion from the Bessel 1841 to Clark 1866 spheroid model.

The spheroid problem can only be resolved if the central meridian and standard parallels used on the chart are known. The only place this information may exist is in the descriptive reports that accompanied each survey when it was submitted to the 
superintendent of CGS or NOS for review and acceptance. At the present time these reports are not available from NOAA, NOS, or the national archives.

Perhaps the greatest barrier to evaluating the overall accuracy of these surveys is the lack of survey stations with known coordinates. Only five to ten percent of the survey stations shown on the Washington and northwest Oregon charts had documented coordinates. These charts were registered by the Department of Ecology using survey stations (when available) and coordinates for locations which had not moved significantly over the last century (e.g., offshore rocks, stream meander bends). This registration process has achieved linear distances accurate to within $\pm 15 \mathrm{~m}$ between known points that were over five kilometers apart. Due to the limitations described above, no attempt was made to apply the detailed error assessment used for the 1920 and 1950 era T-sheets. However, conservative estimates are that the MHWL digitized from the charts are within $\pm 20 \mathrm{~m}$ of their "true" position at the time of survey.

\section{Shoreline Repeatability}

The strength of orthorectified aerial photography is that it provides context and visual queues that assist in identifying the AHWL. However, a potential source of error is that the interpreted location of the AHWL may vary significantly based on the skill level of the staff member doing the digitizing and due to changing interpretations of the contextual information in the photo. These two error sources have been addressed. First, a single individual was tasked with digitizing shorelines from all orthophotography. Second, a detailed description of the visual queues that would be used to identify the erosion reference feature (ERF) (i.e., vegetation or scarp line) and the shoreline change reference feature (SCRF) (i.e., AHWL) were developed and are as follows:

The erosion reference feature (ERF) will be located at the transition zone where vegetation no longer covers more than 50 percent of the ground. In areas where the vegetation line is not visible (e.g., cliffed coast, large sand islands), the ERF will be the top edge of the cliff, bluff/scarp, or top center of the seaward most dune, in that order. In cases where sandy islands have no visible vegetation, only the SCRF will be digitized.

The shoreline change reference feature (SCRF) will be the average high water line (AHWL). This line is estimated based on the dewatering line and drift line. In general, this line is about 5 to $10 \mathrm{~m}$ landward of the darker beach sand, which was wetted by wave run-up within hours of the photo being taken. In a few cases this line will not be visible because:

1) the photo was taken just prior to, or after, high tide;

2) the angle from the ground to the camera was such that high reflectance values mask the difference in shading; or

3) the SCRF is located at a bluff, cliff, or scarp. 
In case 1, the SCRF will be estimated by following the seaward-most dewatering line. In case 2 the location of the SCRF will be estimated based on the location of the drift line (associated with higher high water). The SCRF will be located on the seaward side of the drift line. If waves are breaking at a cliff, bluff, jetty, or scarp (situation three), the SCRF will be collocated with the ERF.

Even with these protocols, the need to quantify the variability in the AHWL delineation process remained. A shoreline repeatability study was designed to look at two different factors that influence this variability:

1) the impact of the source media (prints or diapositives) on the ability of the analyst to identify and digitize the AHWL and the vegetation line; and

2) the ability of the analyst to reproduce the AHWL and vegetation line on identical photos (with and without a constant media).

The experiment design utilized photos from four locations within the Columbia River littoral cell (CRLC) covering 18 kilometers of shoreline. Black and white diapositives and prints were obtained for each site. These photos were scanned at $600 \mathrm{dpi}$ and orthorectified using the same control points for each media type to obtain orthorectified photos with cell sizes of $0.5 \mathrm{~m}$ by $0.5 \mathrm{~m}$. Locational differences between each version of the images were \pm 1 pixel $(0.5 \mathrm{~m})$.

The print/diapositive pairs were presented in random order at three different sittings to the data analyst who was required to digitize the AHWL and vegetation line on each image. To reduce the ability of the analyst to "remember" what they had digitized in the past, the analyst was required to wait 24 hours before digitizing the next set. The difference between the digitized shorelines was calculated using one of the change rate programs used by the Southwest Washington Coastal Erosion Study (Daniels and Huxford, 1998) and are shown in Figure 1.

The diapositive to print analysis obtained a mean difference in the location of the AHWL of $0.22 \mathrm{~m}$ with a standard deviation of $5.22 \mathrm{~m}$ over the 18 kilometers of coast sampled. The print to print analysis, which was conducted for a single photo for $3.5 \mathrm{~km}$ of shoreline, obtained a mean difference of $0.22 \mathrm{~m}$ and a standard deviation of $1.11 \mathrm{~m}$. In contrast, the diapositive to print analysis for this same photo obtained a mean of $0.9 \mathrm{~m}$ and a standard deviation of $1.2 \mathrm{~m}$. Thus, the between sample standard deviation is similar to the between media type variation. This result indicates that the less expensive prints ( $\sim 2$ vs. $\$ 12$ for diapositives) are suitable for delineating the AHWL.

To look at the potential impact of a different analyst digitizing the photos, a second analyst digitized the shoreline and vegetation line for each image. The results of this analysis are shown in Figure 2. The interpretation of the vegetation line had a mean difference of 2.83 $\mathrm{m}$ and a standard deviation of $9.11 \mathrm{~m}$. The interpretation of the AHWL varied by a larger amount, in this case the mean difference was $12.44 \mathrm{~m}$ with a standard deviation of $8.76 \mathrm{~m}$. The second analyst consistently digitized the AHWL further seaward than the first, which 
implies that slightly different visual queues were being used. This indicates that new staff members could be trained to identify the same visual queues used as were used by the original analyst.

\section{Shoreline Variability}

A limitation of the photographic method is that the digitized AHWL is estimated for a single point in time based on evidence visible in the photo from at least the last two high tides. Thus, the digitized AHWL is not based on a long-term record of tide levels as would be implied if we referred to it as the MHWL as is done by NOS. The term MHWL may be taken to refer to a fixed elevation that has been calculated based on a long-term tide gauge record. Thus, the digitized AHWL does not represent the line that would be calculated if the contour line for the MHW elevation were extracted from an elevation model of the beach. However, it is impossible to quantify the difference between the interpreted AHWL and a calculated MHW elevation unless a topographic survey is conducted during, or directly following, the aerial photo mission from which the AHWL was digitized.

There are limitations with the use of context-free topographic surveys as well. On the ocean coast the MHW elevation as seen on the beach is influenced by several factors other than the tide level. These factors include wave height and wave run-up; both of which serve to place the interpreted AHWL further landward than if the MHW elevation were surveyed using traditional spirit levels or GPS technology.

To quantify the variability associated with using an AHWL from a single photo as a surrogate for the mean high water line for an entire season or year several tests were conducted. These tests required the following data collection and creation activities:

1) contracting with the Washington State Department of Natural Resources to fly $1: 12,000$ scale photography of Klipsan Beach in Long Beach, Washington on May 26, 1999;

2) contracting with WAC, Inc., Eugene, Oregon to fly the same area of Long Beach on September 21,1999;

3) orthorectification and digitization of the AHWL from the May and September photos;

4) collection of near-simultaneous topographic maps (with the aerial photo missions) of a 4-km section of Klipsan Beach with ground based GPS systems; and

5) collection of the AHWL and average higher high water line (AHHWL) using groundbased GPS systems for a 10 to $18 \mathrm{~km}$ section of Long Beach centered on Klipsan Beach.

Based on this data the following analyses were conducted:

1) comparing the digitized AHWL from orthophotos with the 2 and $3 \mathrm{~m}$ contours derived from a topographic survey obtained using RTK-GPS methods (the tide gauge- based MHW in Long Beach is $2.11 \mathrm{~m}$ NAVD 88; 
2) overlaying the digitized AHWLs obtained from each flight on their respective topographic surveys to obtain elevation statistics for each line; compare these statistics with those obtained from the GPS-derived AHWL and AHHWL and determine if they are statistically different; and

3) determining the horizontal variation in AHWL line positioning as influenced by the different time and season of the photos.

Figure 3 provides a flow diagram of how the two-dimensional (GPS vs. photo derived AHWL) and the three-dimensional (elevations) parts of this analysis relate.

Results from this experiment are shown in Figures 4 to 7 . In Figures 4 and 5 the ground interpreted AHWL and AHHWL closely coincide with the AHWL digitized from orthophotography. In both May and September the AHWL interpreted on the ground during the GPS surveys were on average within $\pm 12.5 \mathrm{~m}$ of the digitized AHWL. Figures 6 and 7 show the relationship between true elevations (in this case NAVD 88, meters) and the digitized AHWL. The digitized AHWL was overlaid on the topographic surface and the mean elevation was extracted every $10 \mathrm{~m}$ along the line. The May overlay obtained a mean NAVD 88 elevation for the line of $2.68 \mathrm{~m}$ with a standard deviation of $0.14 \mathrm{~m}$. The September overlay obtained a mean NAVD88 elevation for the line of $2.98 \mathrm{~m}$ with a standard deviation of $0.08 \mathrm{~m}$.

The change rate program utilized in the shoreline repeatability analysis (Daniels and Huxford, 1989) was used here. This analysis found that the digitized AHWL receded on average $10 \mathrm{~m}$ from May to September (Standard Deviation $7.31 \mathrm{~m}$ ), during a period in which seaward movement of the shoreline would be expected.

\section{RESULTS}

This three-part analysis was designed to obtain a detailed error budget for all components that enter into the calculation of shoreline change rates for the Southwest Washington Coastal Erosion Study. Initial findings are as follows:

1) MHWLs derived from the 1870 -era NOS T-sheets are estimated to be within $\pm 20 \mathrm{~m}$ of their "true" position at the time of survey;

2) MHWLs derived from the 1920 and 1950-era NOS T-sheets are registered to better than $\pm 6 \mathrm{~m}$; with the addition of the $\pm 6 \mathrm{~m}$ uncertainty associated with interpreting the MHWL on the ground we obtain a mean uncertainty of $\pm 12 \mathrm{~m}$ for the 1920 and 1950era shorelines;

3) AHWLs derived from orthophotos are repeatable to $\pm 2 \mathrm{~m}$; when the known error budget of the orthophotos is considered (i.e., \pm 1.5 to $6 \mathrm{~m}$ ) we obtain a mean uncertainty of $\pm 5.9 \mathrm{~m}$ (for 1:24,000 scale or larger photos) for the photo-derived shorelines; 
4) comparison of the May 1999 to September 1999 AHWL position showed that the photo-interpreted AHWL had moved inland an average of $10 \mathrm{~m}$;

5) the mean vertical elevation of the May 1999 and September 1999 AHWL were $2.68 \mathrm{~m}$ and $2.98 \mathrm{~m}$ NAVD 88 , respectively, a difference of $0.30 \mathrm{~m}$; and

6) the mean beach slope was 2.3 percent in May and 1.7 percent in September.

We can calculate a horizontal distance for all potential AHWL positions for a given month if we assume that the elevation of the AHWL may vary $0.30 \mathrm{~m}$ due to differences in wave and tide conditions at the time of survey and that the slope of the beach flattens in a linear fashion between May and September. For example, based on a 2.3 percent beach slope in May and an elevation difference of $0.3 \mathrm{~m}$ we obtain a conservative estimate of the potential variability of the horizontal location of the AHWL on any day in the month of May of $\pm 13 \mathrm{~m}$ (see Table 1). This value indicates that within the month of May the horizontal position of the AHWL may vary by as much as $13 \mathrm{~m}$ seaward or landward of the digitized AHWL.

Table 2 summarizes the results of the shoreline extraction, repeatability, and variability experiments. The approximate errors and uncertainties associated with deriving an estimate for the AHWL are given, including the shoreline derivation error, the shoreline interpretation uncertainty, the seasonal variability and the total error and uncertainty budget.

\section{CONCLUSIONS}

The AHWLs from orthophotos and the digitized MHWLs from NOS T-Sheets provide shorelines that are accurate to within $\pm 12 \mathrm{~m}$ or better in most cases. However, seasonal variability in the size and location of nearshore sand bars and changes in the beach slope from spring to early fall results in a change in the wave run-up characteristics on a beach. These changes manifest themselves by changing the elevation of the AHWL. Thus, the AHWL was not a fixed value in the experiments but varied between $2.7 \mathrm{~m}$ to $3.0 \mathrm{~m}$ under the "average" weather conditions of 1999, where "average conditions" are characterized by winds of less than 15 knots, mean significant wave heights $\left(H_{s}\right)$ of less than $2 \mathrm{~m}$, and tide levels between 1 and 2 m MLLW.

The elevation variability described above translated into an AHWL that may migrate as much as [13 m (Table 1) + $10 \mathrm{~m}$ (measured horizontal change between May and September) $+17.6 \mathrm{~m}$ (Table 1)] $40.6 \mathrm{~m}$ during the transition from summer to early fall. This natural variation, when combined with the uncertainty associated with the photo derived AHWL, indicates that the interpreted location of the AHWL may vary by month from [13 $\mathrm{m}$ (Table 1) $+5.9 \mathrm{~m}$ (digitized AHWL position uncertainty) $\pm 18.9 \mathrm{~m}$ in May to $[17.6 \mathrm{~m}$ (Table 1) $+5.9 \mathrm{~m}$ (digitized AHWL position uncertainty) $] \pm 23.5 \mathrm{~m}$ in September.

If taken at face value, this range potential AHWL locations during a single spring to earlyfall season results in large uncertainty values. When comparing shorelines from two 
different years, this uncertainty estimate would mask all but the largest changes in shoreline position. Traditionally, uncertainty values are seen as additive terms (e.g., $\pm 5 \mathrm{~m}$ for each shoreline plus the horizontal variability of the potential AHWL for each year). The additive method results in an uncertainty term of $\pm 37.8 \mathrm{~m}$ for the two AHWLs obtained from photos taken on two different years in the month of May. If we assume that these photos were taken ten years apart, the change needs to be less than $-3.7 \mathrm{~m}$ or greater than $3.7 \mathrm{~m}$ per year to be significant.

However, if we explicitly consider the month in which the AHWL was obtained in calculating our uncertainty value, we may view the uncertainty related to natural variability in the position of the AHWL within a single month as a singular term. This would reduce our uncertainty value in the above scenario to $\pm 24.8 \mathrm{~m}$ (from Table 1). This reduces the size of our critical change rate, and would make change values of less than $-2.4 \mathrm{~m}$ or greater than $2.4 \mathrm{~m}$ significant. Table 1 contains an estimate of the average monthly variability of the AHWL for the months of May to September and shows the critical change rate values based on a ten-year and twenty-year time period between shorelines. These ranges assume that the AHWL was digitized under average weather conditions and that the physical state of the beaches in May 1999 and September 1999 is representative of the average condition of the beach for those months over some multiyear period.

Based on this analysis Figure 8 was constructed. This figures identifies all AHWL segments within Washington whose erosion rates exceed the critical change rate value of $\pm 1.4 \mathrm{~m} /$ year for the period 1974 to 1995 . The AHWL shown is from $1: 12,000$ photography taken in August and September of 1995.

\section{REFERENCES}

Daniels, R.C., and Huxford, R.H. 1999. An Error Assessment of Vector Data Derived from Scanned NOAA, Topographic Sheets, Unpublished white paper, Coastal Monitoring \& Analysis Program, Washington Department of Ecology.

Daniels, R.C. and Huxford, R. H. 1998. Coastline Mapping and Identification of Erosion Hazard Areas in Pacific County, Washington, In: 1998 ESRI International User Conference Proceedings, ESRI.

Huxford, R.H. and Daniels, R.C. 1998. Historical map recovery using multiple integrated ESRI programs, ESRI Eighteenth Annual User Conference Proceedings, ESRI.

National Ocean Service 1999. FY 1999 Vector Shoreline Acquisition and Maintenance Plan, U.S. Department of Commerce, National Oceanic and Atmospheric Administration, National Ocean Service, Marine Chart Division.

Shalowitz, A.L. 1964. Shore and Sea Boundaries, Volume 2, U.S. Department of Commerce, Coast and Geodetic Survey, Washington, DC. 


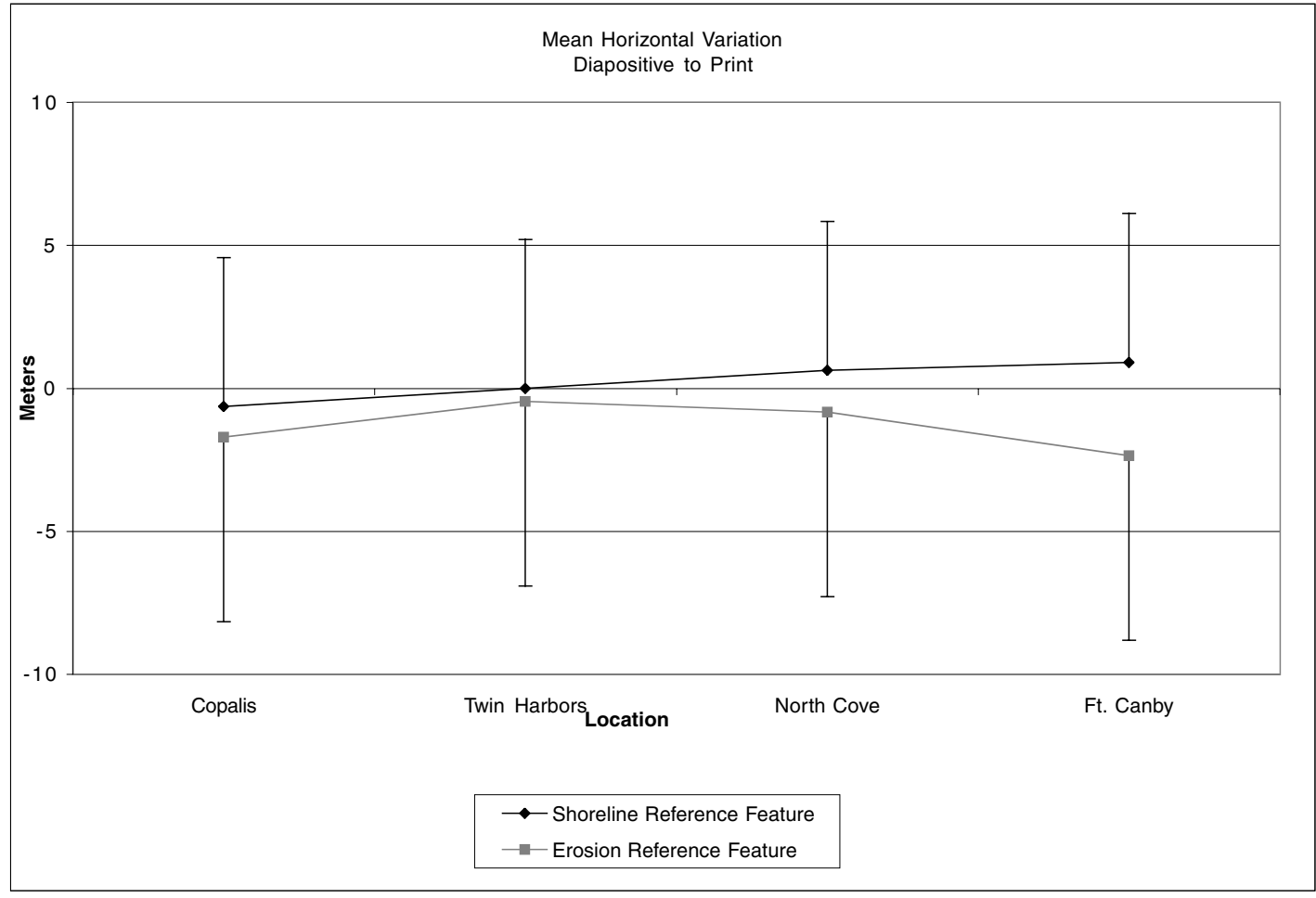

Figure 1. Mean variation between the repeated interpretation of the average high water line for four locations within the Columbia River littoral cell. 


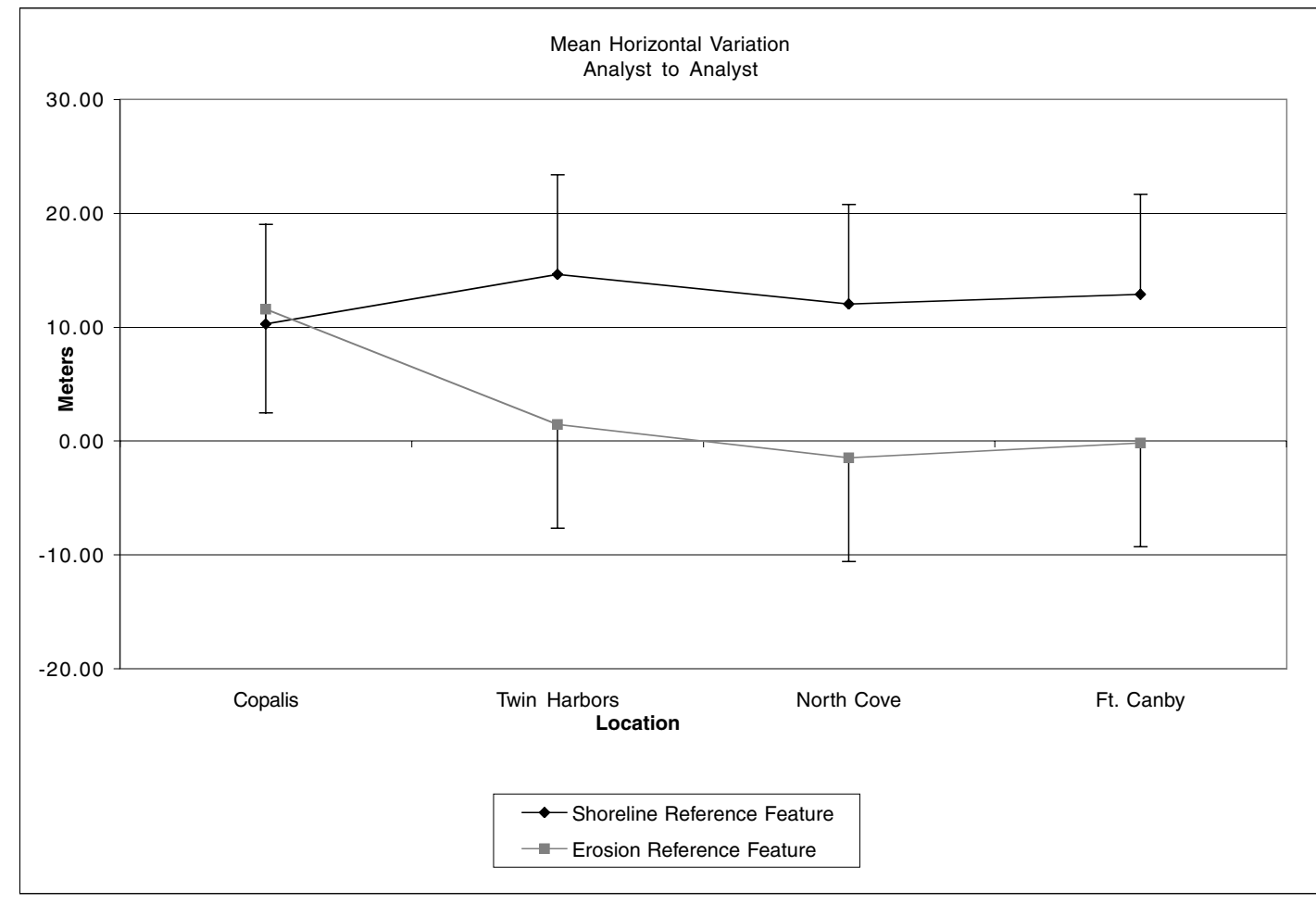

Figure 2. Mean difference between the interpreted average high water line digitized by two different analysts for four locations within the Columbia River littoral cell. 


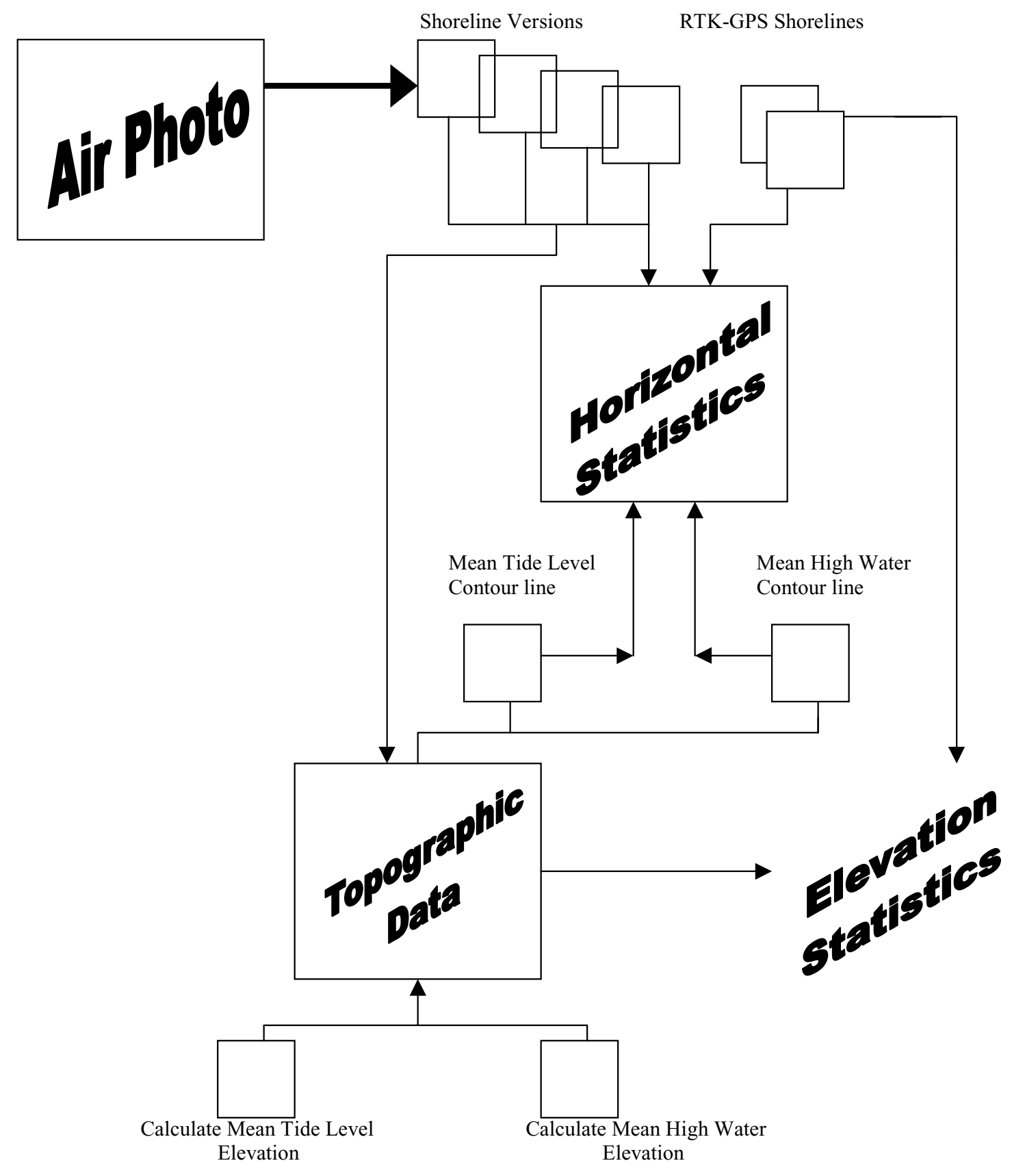

Figure 3. Schematic diagram showing the interconnections between different portions of the shoreline variability study. 


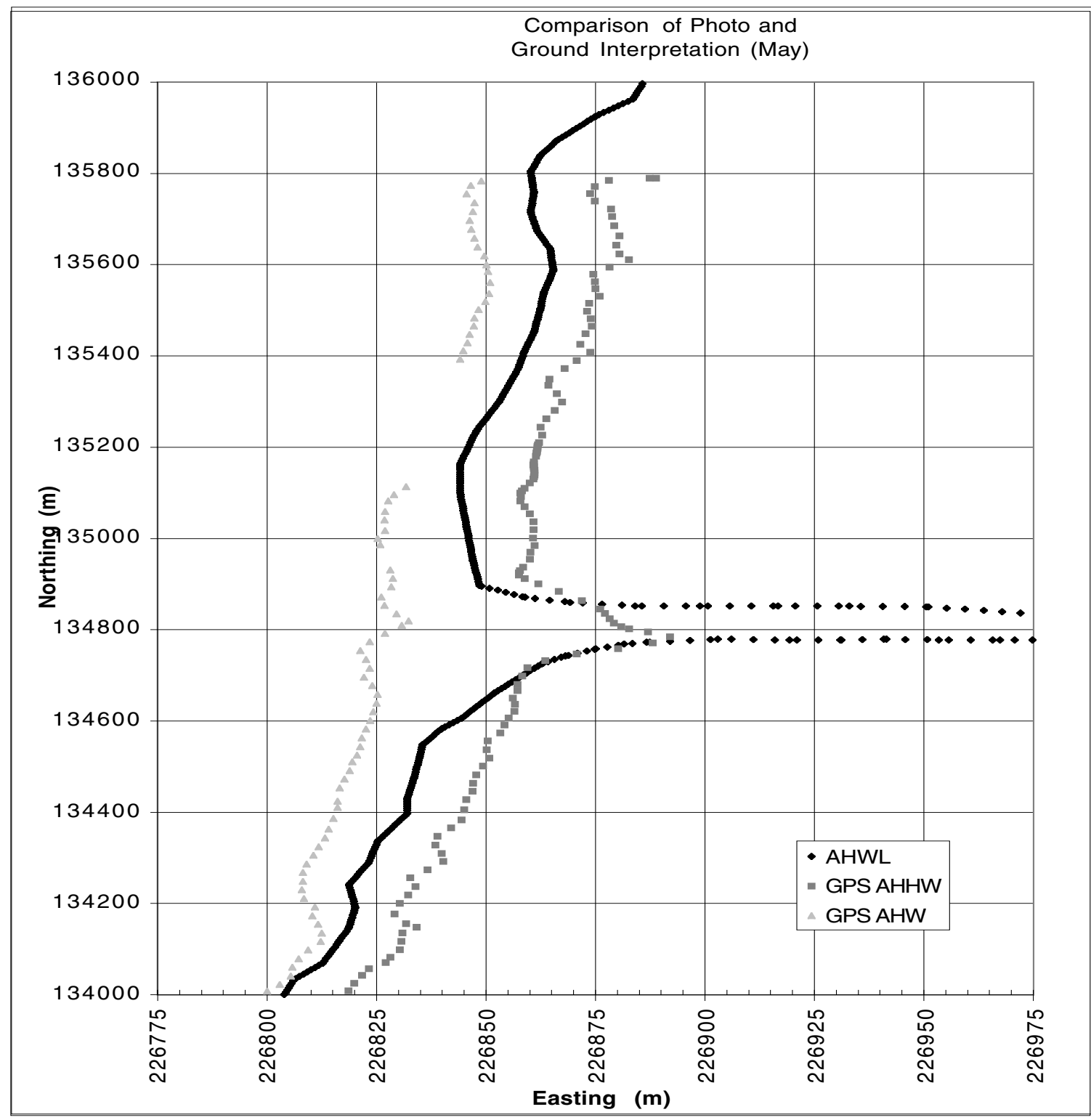

Figure 4. Comparison of a photo derived AHWL for May 26, 1999 with an AHWL and AHHWL obtained from a ground survey taken one day after the flight. 


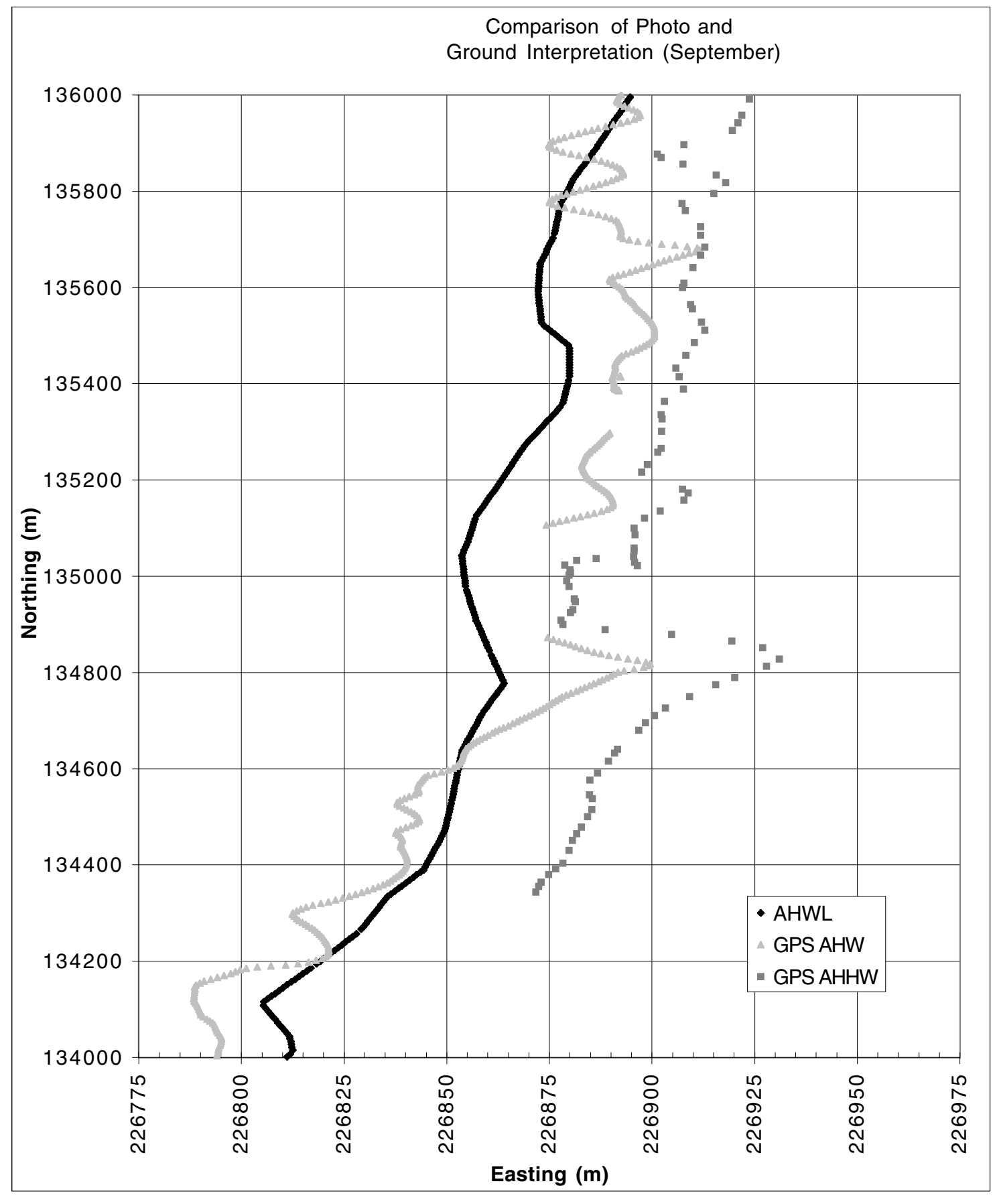

Figure 5. Comparison of a photo derived AHWL for September 21, 1999 with an AHWL and AHHWL obtained from a ground survey taken three days after the flight. 


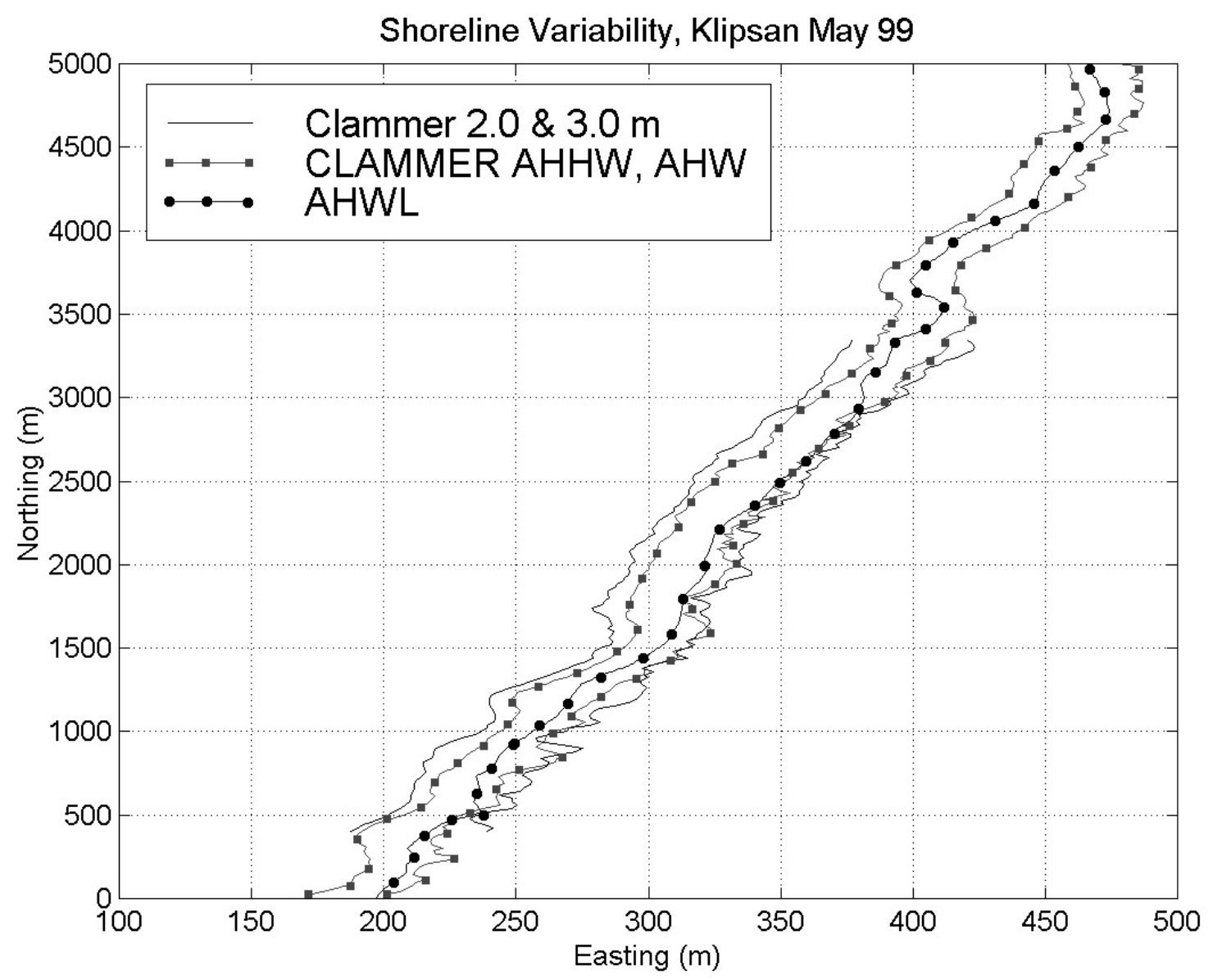

Figure 6. Comparison of GPS derived two and three meter contours with the digitized AHWL for May 26, 1999. Mean AHWL elevation is $2.68 \mathrm{~m}$. 


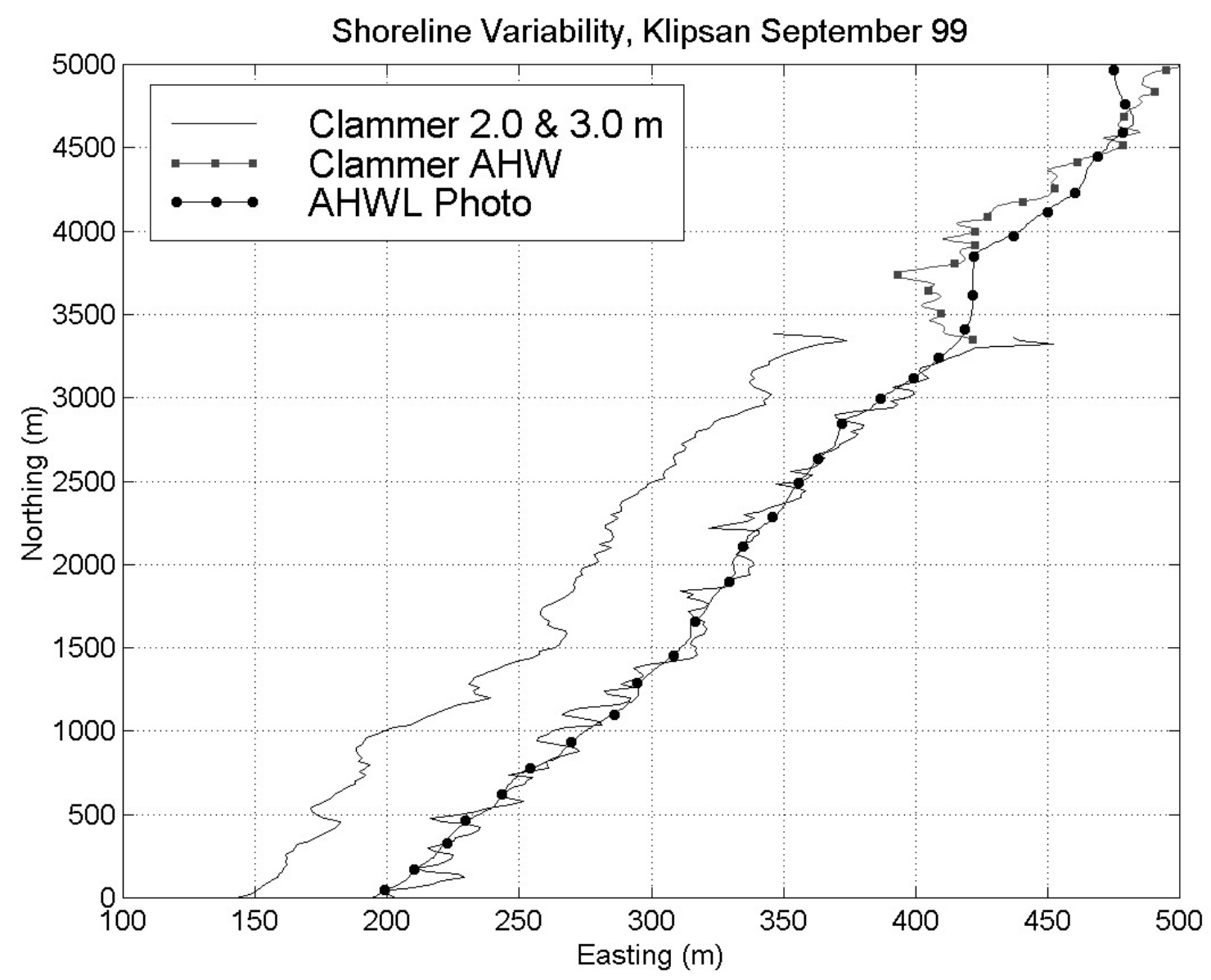

Figure 7. Comparison of GPS derived two and three meter contours with the digitized AHWL for September 21, 1999. Mean AHWL elevation is $2.98 \mathrm{~m}$. 


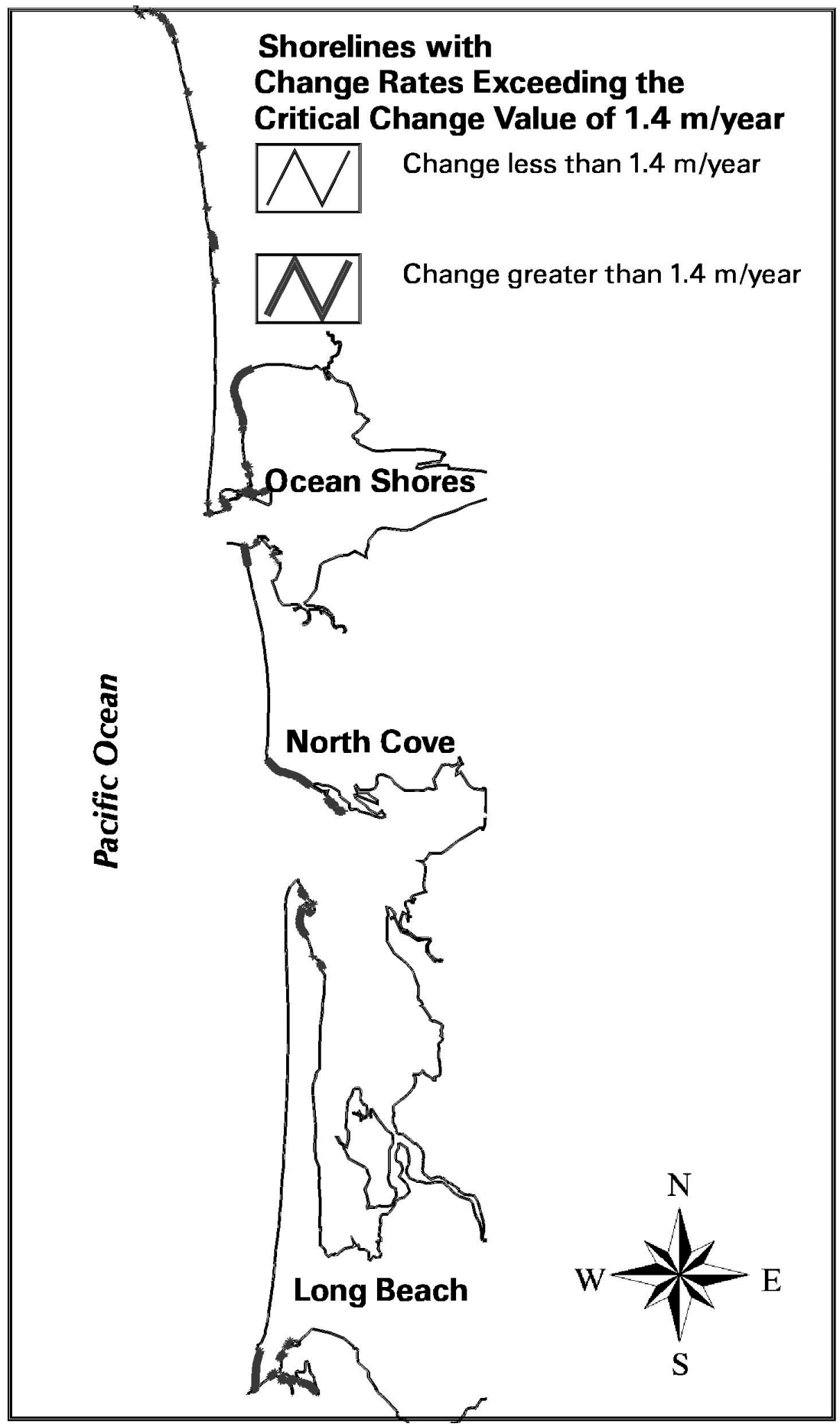

Figure 8. Shorelines in Washington with measured erosion rates exceeding the critical change rate for the period 1974 to 1995. 
Table 1. Estimate of the average monthly variability of the AHWL for the months of May to September and the critical change rate values based on a ten-year and twenty-year time period between photos.

\begin{tabular}{lllllcc}
\hline Shoreline & Beach & AHWL & $\begin{array}{l}\text { AHWL } \\
\text { (Photo) }\end{array}$ & Total & \multicolumn{2}{c}{ Critical Change Rate } \\
Month & Slope & $\begin{array}{l}\text { Variability } \\
(\mathbf{m})\end{array}$ & $\begin{array}{l}\text { Repeatability } \\
(\mathbf{m})\end{array}$ & $\begin{array}{l}\text { Uncertainty } \\
(\mathbf{m})\end{array}$ & $\begin{array}{c}\mathbf{1 0} \text { Years } \\
(\mathbf{m} / \mathbf{y r})\end{array}$ & $\begin{array}{c}\mathbf{2 0} \text { Years } \\
(\mathbf{m} / \mathbf{y r})\end{array}$ \\
\hline May & $2.30 \%$ & 13.0 & 5 & 23.0 & 2.3 & 1.2 \\
June & $2.15 \%$ & 14.0 & 5 & 24.0 & 2.4 & 1.2 \\
July & $2.00 \%$ & 15.0 & 5 & 25.0 & 2.5 & 1.3 \\
August & $1.85 \%$ & 16.2 & 5 & 26.2 & 2.6 & 1.3 \\
September & $1.70 \%$ & 17.6 & 5 & 27.6 & 2.8 & 1.4 \\
\hline
\end{tabular}

Table 2. Total error and uncertainty budget for AHWL estimates.

\begin{tabular}{lllll}
\hline & $\begin{array}{l}\text { Shoreline } \\
\text { Derivation } \\
\text { Error }(\mathbf{m})\end{array}$ & $\begin{array}{l}\text { Shoreline } \\
\text { Interpretation } \\
\text { Uncertainty }(\mathbf{m})\end{array}$ & $\begin{array}{l}\text { Seasonal } \\
\text { Variability }(\mathbf{m})\end{array}$ & $\begin{array}{l}\text { Total Error and } \\
\text { Uncertainty }(\mathbf{m})\end{array}$ \\
\hline $\begin{array}{l}1880 \text { era } \\
\text { T-sheets }\end{array}$ & \pm 20 & \pm 6 & \pm 15 & \pm 41 \\
$\begin{array}{l}1920 \text { and 1950- } \\
\text { era T-sheets }\end{array}$ & \pm 6 & \pm 6 & \pm 15 & \pm 27 \\
$\begin{array}{l}\text { Aerial } \\
\text { Photography }\end{array}$ & \pm 3 & \pm 2 & \pm 15 & \pm 20 \\
\hline
\end{tabular}




\section{BATHYMETRIC VOLUME CHANGE: DATA AND ANALYSIS}

Ann Gibbs, U.S. Geological Survey

\section{INTRODUCTION}

Three different types of bathymetric data sets are being developed for morphological and volumetric change analysis within the Columbia River littoral cell: 1) regional bathymetry over the entire study area; 2) local bathymetry at inlets; and 3) regional historical and recent bathymetry grids created for wave modeling experiments.

The regional bathymetry within the study area database includes National Ocean Service (NOS; formerly U.S. Coast and Geodetic Survey; USC\&GS) hydrographic survey data collected during two time periods, 1868-1891, and 1926-1927, and the following U.S. Army Corps of Engineers (Corps) surveys: 1900 and 1927 (Grays Harbor), and 1935 (Columbia River). This data set extends from Tillamook Head, Oregon to Point Grenville, Washington and from the shoreline to between 2 and $5 \mathrm{~km}$ offshore ( 100-700 m water depth). The 1926 bathymetry is the most recent data available over most of the study area (Figure 1).

The localized inlet bathymetry data set includes both NOS and Corps hydrographic data collected over four time periods: pre-jetty (1868-1877), post-jetty-1 early (1926-1935) post-jetty-2 (1954-1958), and modern (1998-1999). This data set typically covers the flood- and ebb-tidal delta regions of the respective inlets, to water depths of approximately 60 meters.

The four bathymetric grid surfaces generated for use in wave modeling experiments include hydrographic data compiled over two areas (regional and nested) and two time periods (1920s and 1990s). The large, regional data set (REG26) is comprised of NOS hydrographic survey data, collected between 1926 and 1930, and extending from Heceta Head, Oregon to Cape Johnson, Washington, between 3 and $10 \mathrm{~km}$ offshore. Nested within the large REG26 area is a smaller data set comprised of more rigorously edited and processed NOS data (NEST26). Modern (1998) regional and nested grids were created by merging the 1926 data sets with 1998 surveys collected by the Army Corps of Engineers around Grays Harbor, Willapa Bay, and Columbia River mouth (Figure 2). Because of large changes in the location and morphology of these ebb-tidal deltas since 1926, the transition between historic and modern bathymetry is, in places, abrupt and irregular. In order to obtain a smooth transition across the survey boundaries, it was necessary to selectively edit, modify, and add new data based on inferred shoreface and tidal-delta morphology (Gibbs, in prep). The results of this work represent a reasonable estimate of the true morphology, however, the reader is cautioned to only use this data set with full knowledge of the original intent, the limitations, and assumptions used to generate it. Additional surveys collected during 1999 (Figure 3) will aid in developing a more accurate representation of the modern bathymetry in the next version (v2). 


\section{PRELIMINARY RESULTS OF THE REGIONAL BATHYMETRIC CHANGE ANALYSIS}

One component of this project is to understand the historical change in regional bathymetry, in order to quantify the large-scale, long-term changes in offshore sediment behavior. This information will help define the role of the inner-shelf within the regional sediment budget, and how changes in nearshore morphology may or may not correlate with changes observed in the position of the shoreline. Gibbs and Gelfenbaum (1999) address the accuracies and errors associated with the historic hydrographic data base and present preliminary results of bathymetric change observed between 1868 and 1927 (Figure 3). These findings are summarized below.

Volumetric analysis of the regional historical (1870s vs. 1920s) bathymetric data set is problematic due to the age of the surveys (1870s and 1920s), the original intent of the surveys (to identify the depth of the sea floor as an aid to navigation), the techniques involved (potential sounding and horizontal positioning errors), and the high-energy conditions (seas, swell, and currents) along this stretch of coast.

Surveys collected closer to shore, in water depths less than -30 m, contain smaller errors and define the sea-floor morphology well. Errors and uncertainties increase with depth and distance offshore. Comparison between these two surveys shows large areas of both accretion and erosion on the shelf between the shoreline and $-70 \mathrm{~m}$ of water, with the greatest change occurring off the mouth of the Columbia River.

The 1870 s data set provides detailed coverage in only two locations where a reasonable representation of sea-floor morphology can be interpreted (off the Grayland Plains and the Columbia River Mouth). In these areas, calculation of volumetric changes is likely accurate within the bounds of our confidence interval $( \pm 1.7 \mathrm{~m}$; Gibbs and Gelfenbaum, 1999). In other locations, the quantitative value of the data set is more questionable due to the large range of uncertainties. Large signals that exceed our potential error estimates, however, suggest that real changes in the offshore sea-floor morphology are occurring. Lacking additional insight into the magnitude and distribution of these errors, primarily related to the application of tidal corrections and sounding errors associated with horizontal offset, only a first order, qualitative application of the volumetric change data should be expected. Quantitative analysis and interpretation of the regional bathymetric changes within the Columbia River littoral cell should be approached with caution and with a thorough knowledge of the error distribution and uncertainties associated with the data set.

\section{REFERENCES}

Gibbs, A.E., Buijsmain, M.C., and Sherwood, C.R. in prep. Gridded Bathymetry Data Washington-Oregon Coast: 1926-1998 Data release and description of methods Version 1.0, U.S. Geological Survey Open-File Report.

Gibbs, A. E., and Gelfenbaum, G. 1999. Bathymetric change off the Washington-Oregon coast, Proceedings of Coastal Sediments '99, ASCE, pp. 1627-1641. 


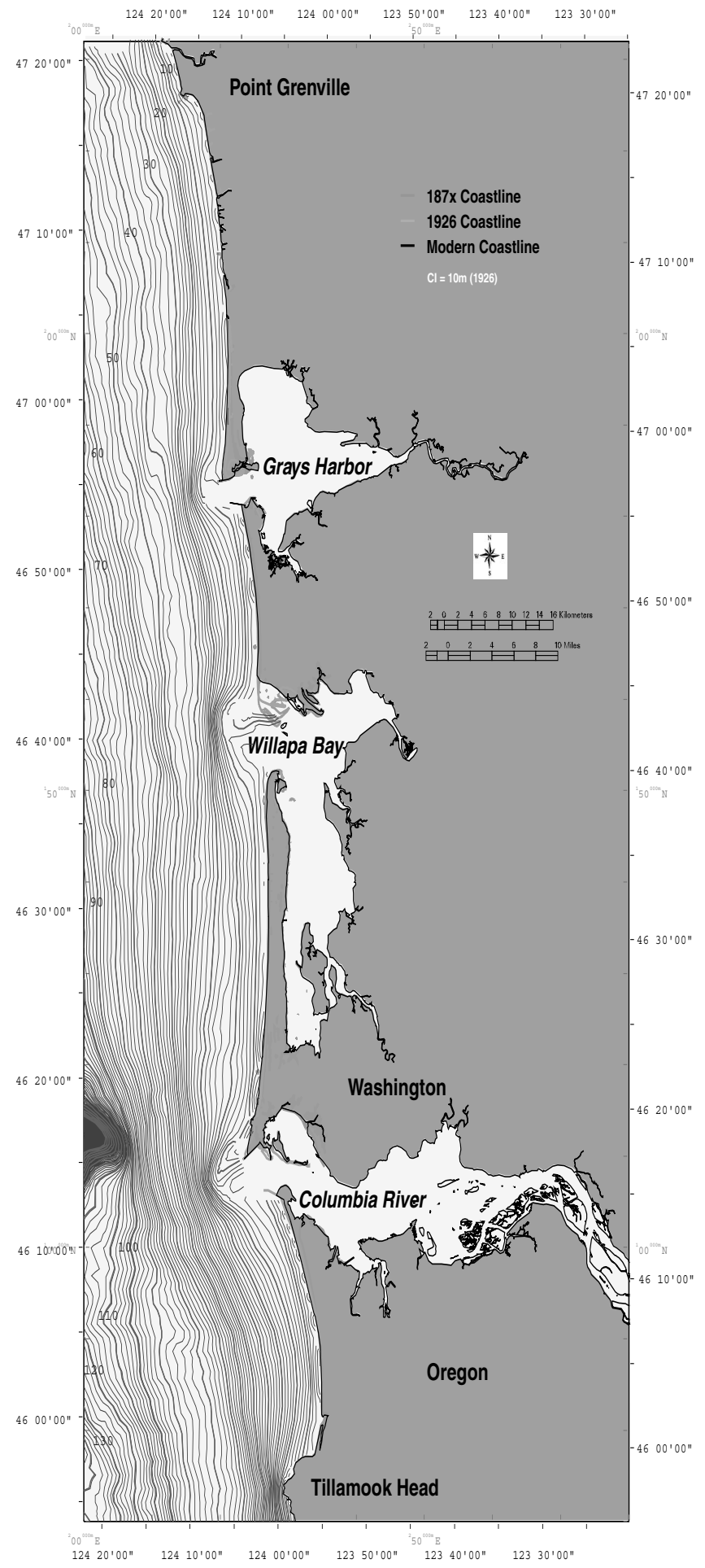

Figure 1. Bathymetry within the Columbia River littoral cell. The most recent data available on a regional scale are from 1926. 

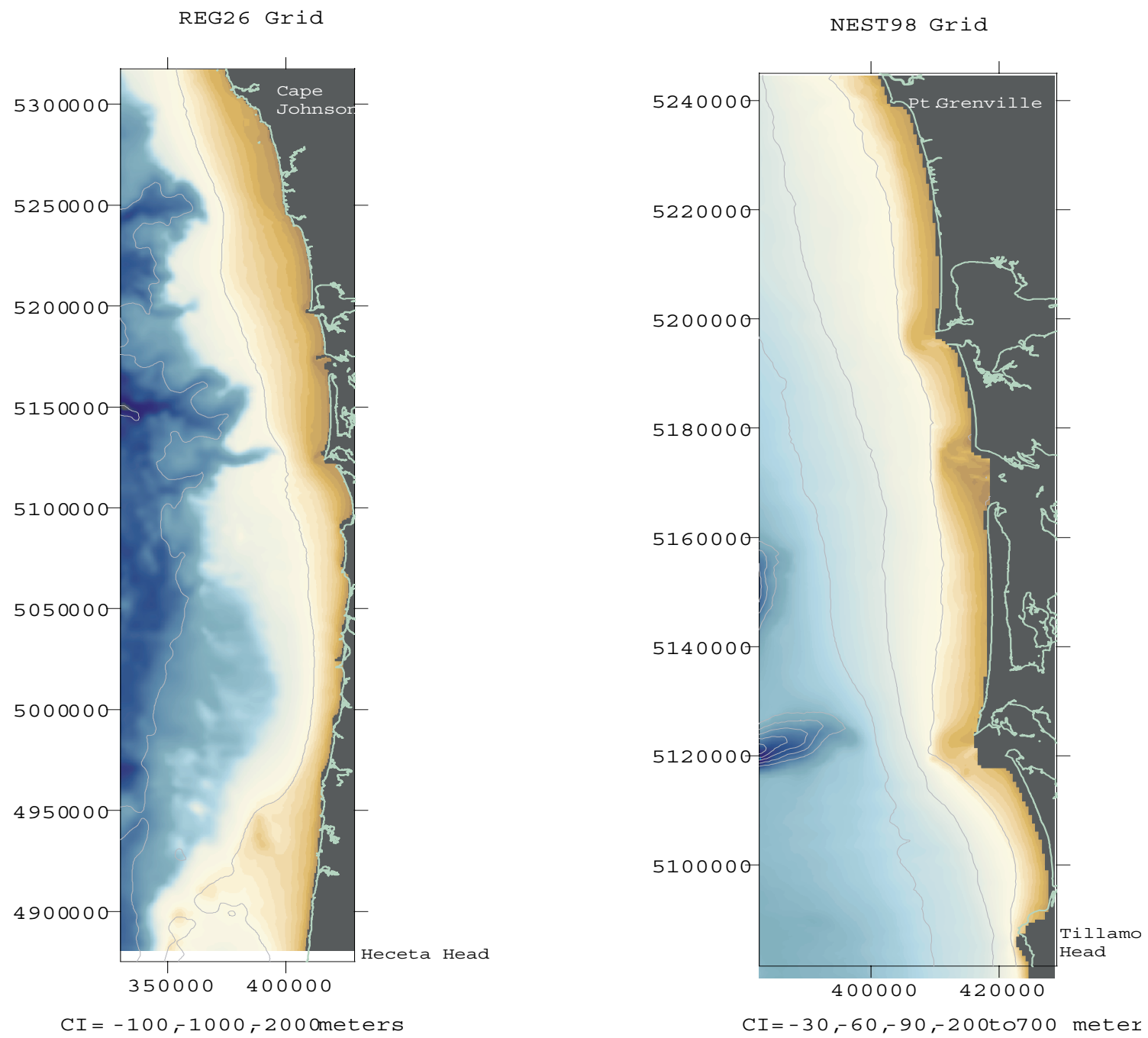

Figure 2. Examples of the regional (REG26) and nested (NEST98) grids created for the wave modelling experiments. 


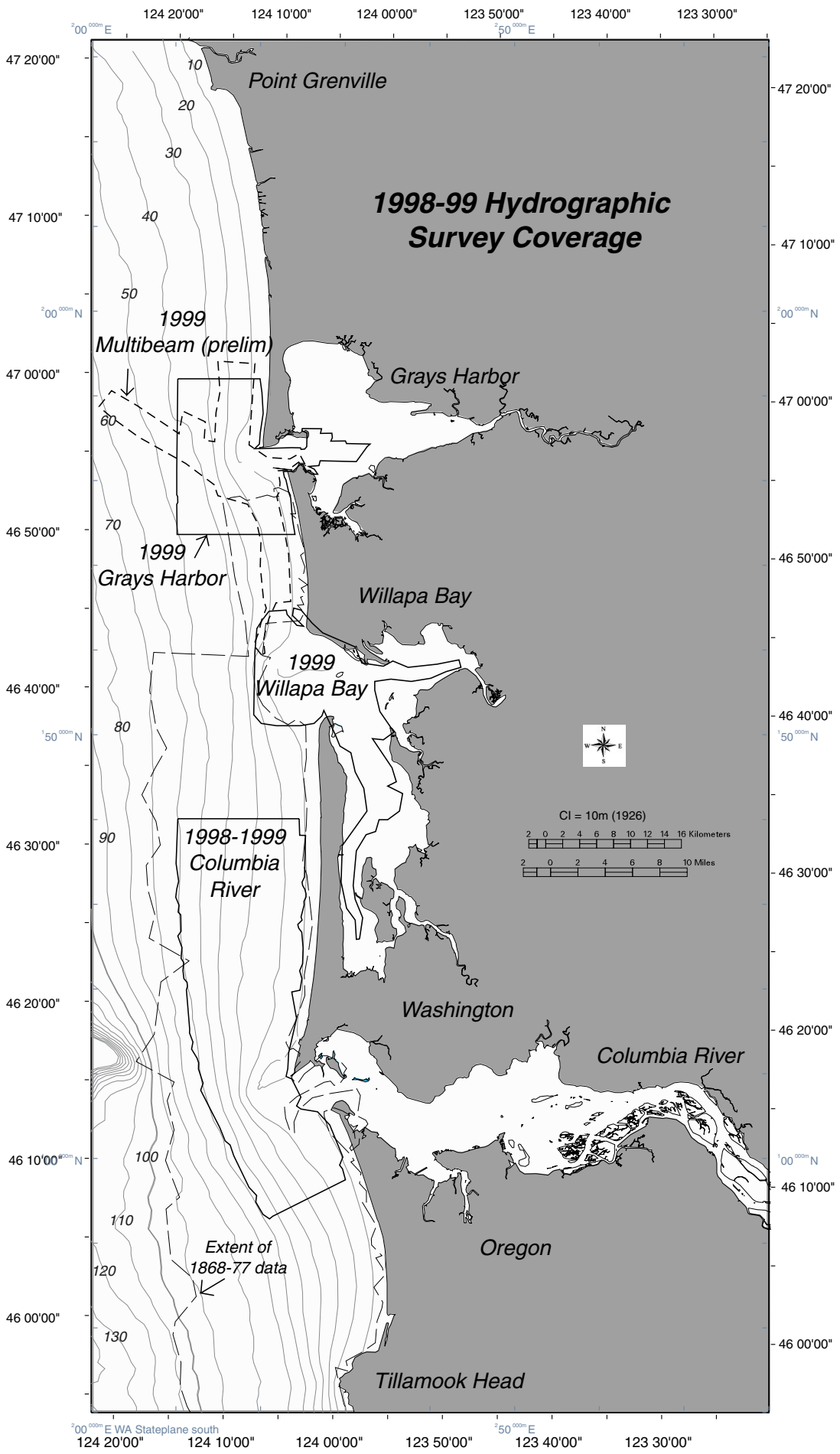

Figure 3. Boundaries of several new hydrographic surveys collected in 1998 and 1999. 


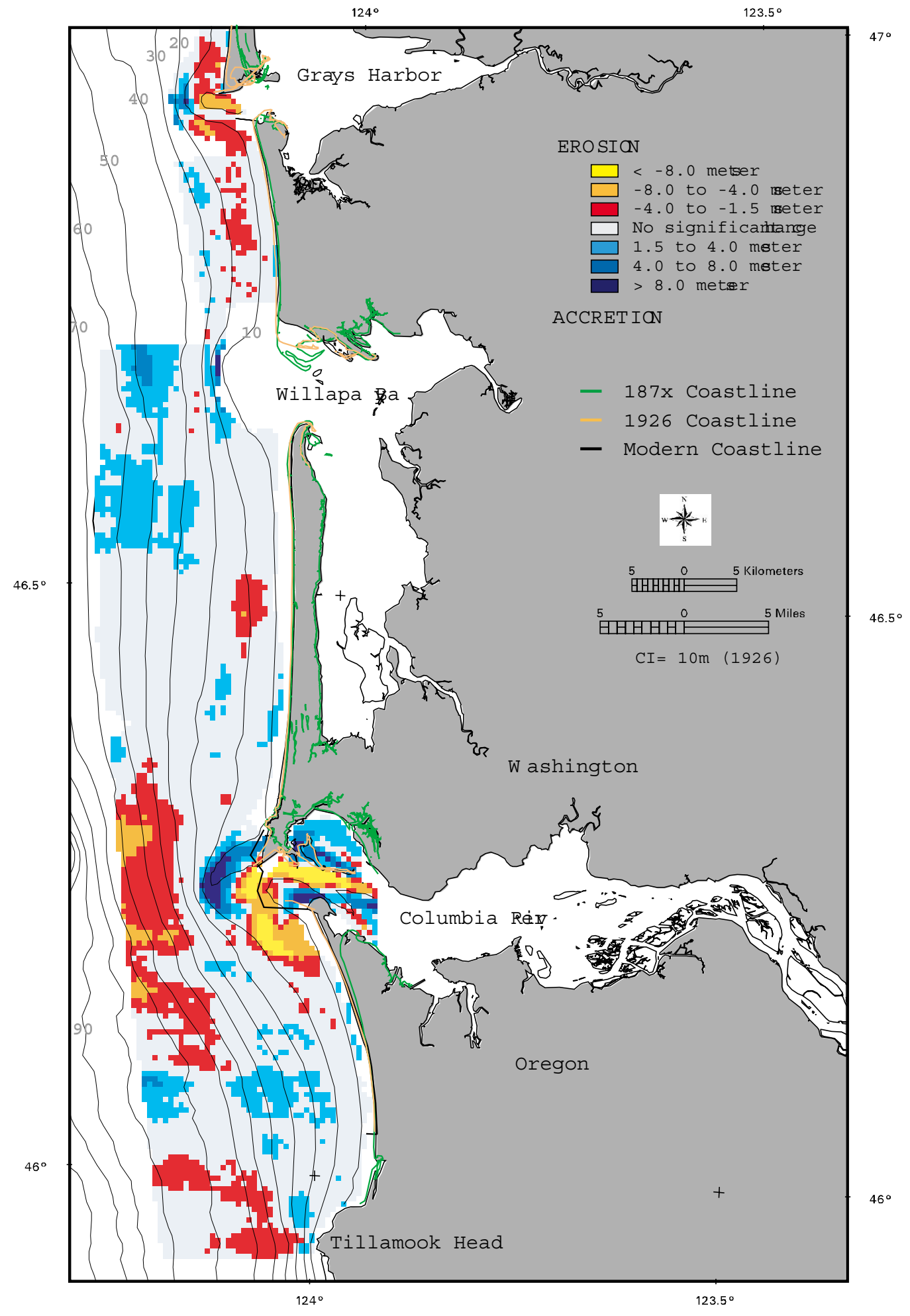

Figure 4. Regional bathymetric change within the Columbia River littoral cell between 1868 and 1935. 


\title{
PRELIMINARY RESULTS OF A MULTIBEAM BATHYMETRY AND BACKSCATTER SURVEY
}

\author{
Roger D. Flood, Marine Sciences Research Center, SUNY Stony Brook \\ Vicki Lynn Ferrini, Marine Sciences Research Center, SUNY Stony Brook \\ Liviu Giosan, Marine Sciences Research Center, SUNY Stony Brook \\ Laurie Zaleski, Marine Sciences Research Center, SUNY Stony Brook
}

\begin{abstract}
A multibeam survey of the region off Grays Harbor was conducted from August 27 to September 10, 1999, to determine bathymetry in the region from about 12 to $60 \mathrm{~m}$ water depth. There is nearly 100 percent coverage to about $30 \mathrm{~m}$ water depth, nearly 50 percent coverage to $40 \mathrm{~m}$ water depth, and isolated tracks to $60 \mathrm{~m}$ water depth (Figure 1). The survey was conducted using an EM 3000 multibeam echo sounder installed on the 65' UW Research Vessel R/V Clifford A. Barnes. Much of the area we studied had not been mapped since regional bathymetric surveys in the early 20th century. New regional bathymetric data were needed in this area for modeling wave refraction and shoreface evolution, for calculating sediment-transport rates, to produce an updated bathymetric change map to identify regions of erosion and deposition. Backscatter data were also collected during our survey to provide independent information about sediment character. In addition bathymetric contours referenced to NAVD88 and backscatter, the bathymetric information can be processed to produce images of sun-illuminated topography to allow intermediate-scale features to be identified on the sea bed. The combination of bathymetry, sun-illuminated bathymetry, and backscatter provides a new view of the seabed morphology off southwest Washington that will improve our understanding of sediment movement, shoreline change, and the role of tectonics in coastal processes.
\end{abstract}

The MSRC EM 3000 was used in a dual-head mode with two transducers providing a swath width:depth ratio of 10:1 at $10 \mathrm{~m}$ depth, decreasing to 5:1 at $40 \mathrm{~m}$ depth. This swath is considerably wider than the swath to be expected using a single head, and allowed for much more efficient survey operations. We utilized real-time kinematic GPS (RTK) for both vertical elevation as well as for position, and CTD casts were made to determine sound-velocity structure in the water column. The RTK data was filtered to create a local tide curve, and this tidal elevation correction was then applied to the calculated depths to determine absolute water depth. Our survey resulted in a depth measurement (nominally accurate to about $5-10 \mathrm{~cm}$ ) at least every $1 \mathrm{~m}$ along track and $5 \mathrm{~m}$ across track, with higher sounding densities in shallower water. Subsequent to our survey, 17 sediment samples were collected by the USGS in order to allow the origin of some of the more prominent backscatter patterns to be understood.

Images of the sea bed resulting from the multibeam imagery show a number of features that were unexpected and that may have significance in understanding sediment transport patterns and coastal evolution patterns in the study area. 
One of the more unexpected discoveries was a series of depressions south and east of the submerged south jetty at Grays Harbor at water depths of 10 to $16 \mathrm{~m}$ that commonly have high backscatter. These depressions are up to $2 \mathrm{~m}$ deep, up to $200 \mathrm{~m}$ wide, and up to $1 \mathrm{~km}$ long. The largest depressions are within $3 \mathrm{~km}$ of the jetty, but smaller depressions are observed at greater distances south of the jetty. Some of the smaller depressions appear similar in morphology to ground-water seeps on land. Where sampled, the highly reflective regions consist of gravel-sized sediment while sediment adjacent to the high backscatter regions consists of well-sorted fine to medium sand. Sediment distribution patterns appear consistent with bed load transport directions to the northwest.

A large region of high backscatter was also observed north of Grays Harbor entrance (off Ocean Shores). The shallow extent of this region is at about $12 \mathrm{~m}$ water depth, similar to that observed for high backscatter regions south of the jetty. However, the region of high backscatter widens with depth to over $5 \mathrm{~km}$ at $30 \mathrm{~m}$ depth and covers much of the mapped sea bed at depths greater than $30 \mathrm{~m}$ at this latitude. Grab samples show that the high backscatter sea floor consists of gravel-sized sediment whereas adjacent sediments are sand sized. Sediment morphology appears consistent with bed load transport towards the north. In some areas the multibeam data show protrusions from the sediment, probably bedrock outcrops. The region of high backscatter appears to correspond to a fault mapped by others on the basis of seismic profiles in this area.

A number of other phenomena were also observed on the multibeam data products, including a distinctive zone of high backscatter around the outer edge of the ebb-tidal delta, a region of somewhat elevated backscatter extending at least $10 \mathrm{~km}$ south of the jetty, and morphology along the northern side of the south Jetty suggestive of sand leakage through the jetty.

Multibeam bathymetry and backscatter data in the study area provide new insights into the nature of sea-bed morphology in the coastal zone off southwest Washington. Continued analysis of these new data will support studies of sediment transport patterns in this area. 


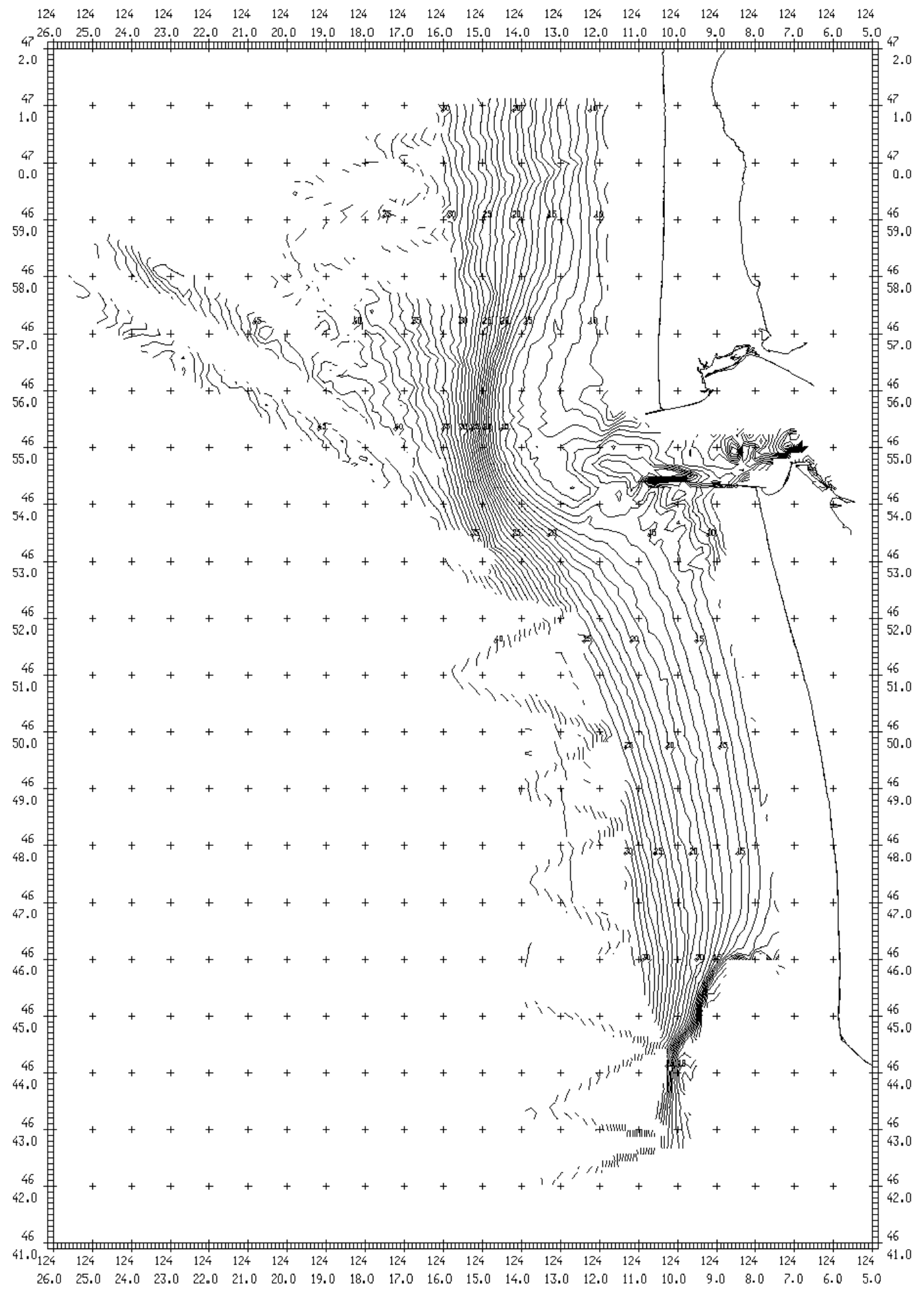

Figure 1. Preliminary multibeam bathymetric map collected off of Grays Harbor, Washington. Contour interval $=1 \mathrm{~m}$, datum $=$ MLLW. 


\title{
THE INNER SHELF: SOURCE OR SINK FOR BEACH SAND?
}

Dave C. Twichell, U.S. Geological Survey

VeeAnn A. Cross, U.S. Geological Survey

Kenneth F. Parolski, U.S. Geological Survey

\begin{abstract}
Two questions raised at the outset of the Southwest Washington Coastal Erosion Study were (1) what is the seaward limit of the lower beach face, and (2) is the shelf a source of sand for the beaches? Surface sediment grab samples and widely-spaced side-scan sonar lines were collected to address these questions from a sedimentologic perspective. Seventeen shore-perpendicular transects of grab samples were collected off the beaches of this littoral cell. Mean grain size, in general, decreases from 2.5-3.0 phi in water depths less than approximately $20 \mathrm{~m}$ to $3.5-4.0 \mathrm{phi}$ in water depths greater than $45 \mathrm{~m}$ (Figure 1). No clear sedimentological break was shown separating the lower beach face from the inner shelf, so the transition was arbitrarily chosen at a mean grain size of 3 phi (125 microns). This transition occurs in roughly $25-\mathrm{m}$ water depth. The inner shelf is divided into two distinctive provinces: a relict shelf north of the Grayland area and a modern shelf to the south. Outcrops of Tertiary strata, and patches of glacial gravel are abundant north of the mouth of Grays Harbor while they are completely absent to the south due to these older deposits being buried by modern sediment. Samples from the lower beach face show that the mean grain size is fairly uniform along the entire length of the study area (Figure 2). Partitioning the grain-size results by 1-phi intervals shows distinctive variations in the along-shore and across-shore directions that are not shown by the meangrain size values. Four transects across the lower beach face and inner shelf demonstrate the difference between the relict and modern shelf surfaces and the lower beach face shoreward of each of these two offshore provinces (Figure 3). The two northern transects, which cross the relict shelf surface, show that medium and coarse sand comprise 40-50 percent of the lower beach face samples and 10-40 percent of samples from the inner shelf. Off Long Beach, medium to coarse sand is absent, and the fine sand component decreases offshore from 70 percent in $11 \mathrm{~m}$ to only 27 percent in $33 \mathrm{~m}$ water. Off Clatsop the same trend holds although it is not as pronounced (fine sand component is 68 percent in $8 \mathrm{~m}$, and 42 percent in $29 \mathrm{~m}$ ). The textural similarity of the relict shelf and the lower beach face north of Willapa Bay, suggests that, here, the inner shelf could be a source of sand for at least the lower beach face. Where the modern shelf deposit is present, however, the small fraction of fine sand in inner shelf samples relative to the beach samples suggests that it is not a significant sand source to the beaches. Because of the progression in surface sediment texture, it seems more plausible that the shelf is a sink for sand lost from the beach rather than being a source of sand for the beaches.
\end{abstract}




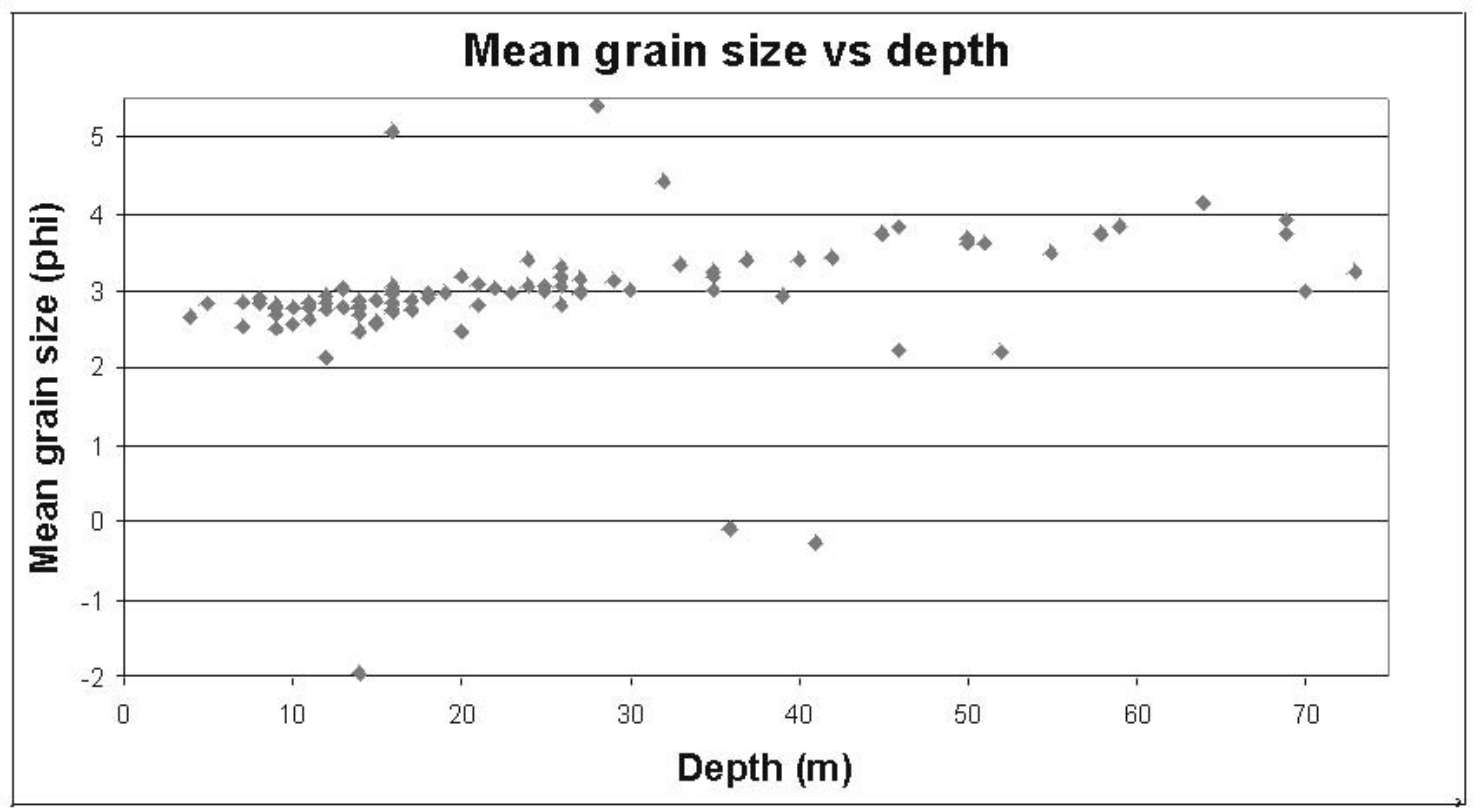

Figure 1. Graph of mean grain size verses depth of surface sediment grab samples collected from the lower beach face and inner shelf in 1998. Note that the general trend is for sediment to become finer offshore. The lower beach face samples have mean grain sizes of 2-3 phi (fine sand) while the inner shelf samples, except north of Willipa Bay are finer grained. 


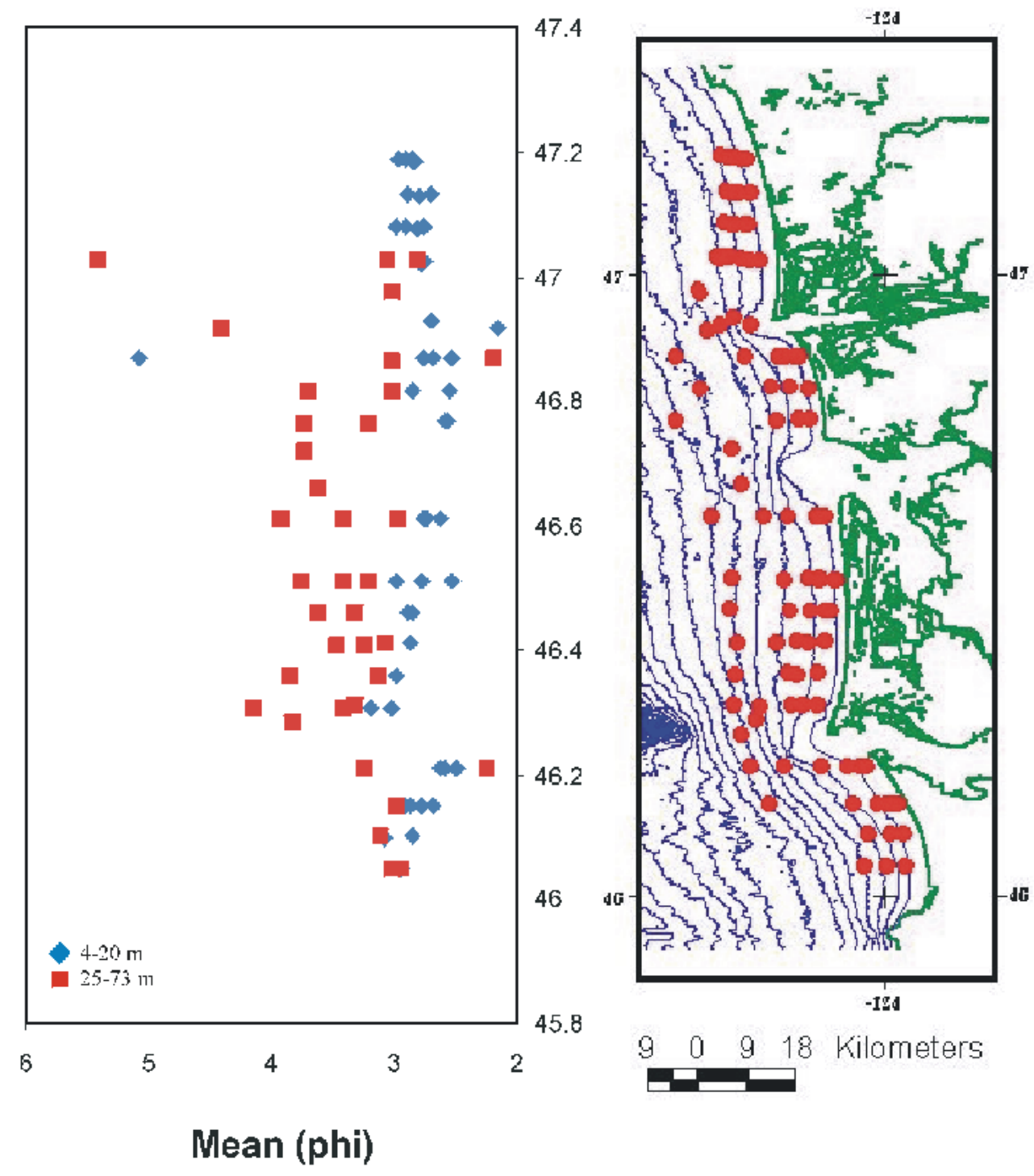

Figure 2. Variations in mean grain size along transects collected in the Columbia River littoral cell. Samples in water depths of 4-20 m (roughly the lower beach face) are colored blue and samples in water depths of 25-73 $\mathrm{m}$ (the inner and middle shelf) are colored red. Lower beach face samples are coarser than the inner shelf samples, but it is interesting that they are finest off the mouth of the Columbia River, become progressively coarser to Grayland, and then become finer north of Grays Harbor. The inner/middle shelf samples become finer to the north, and the increased scatter north of Grayland reflects the nature of this part of the shelf. 

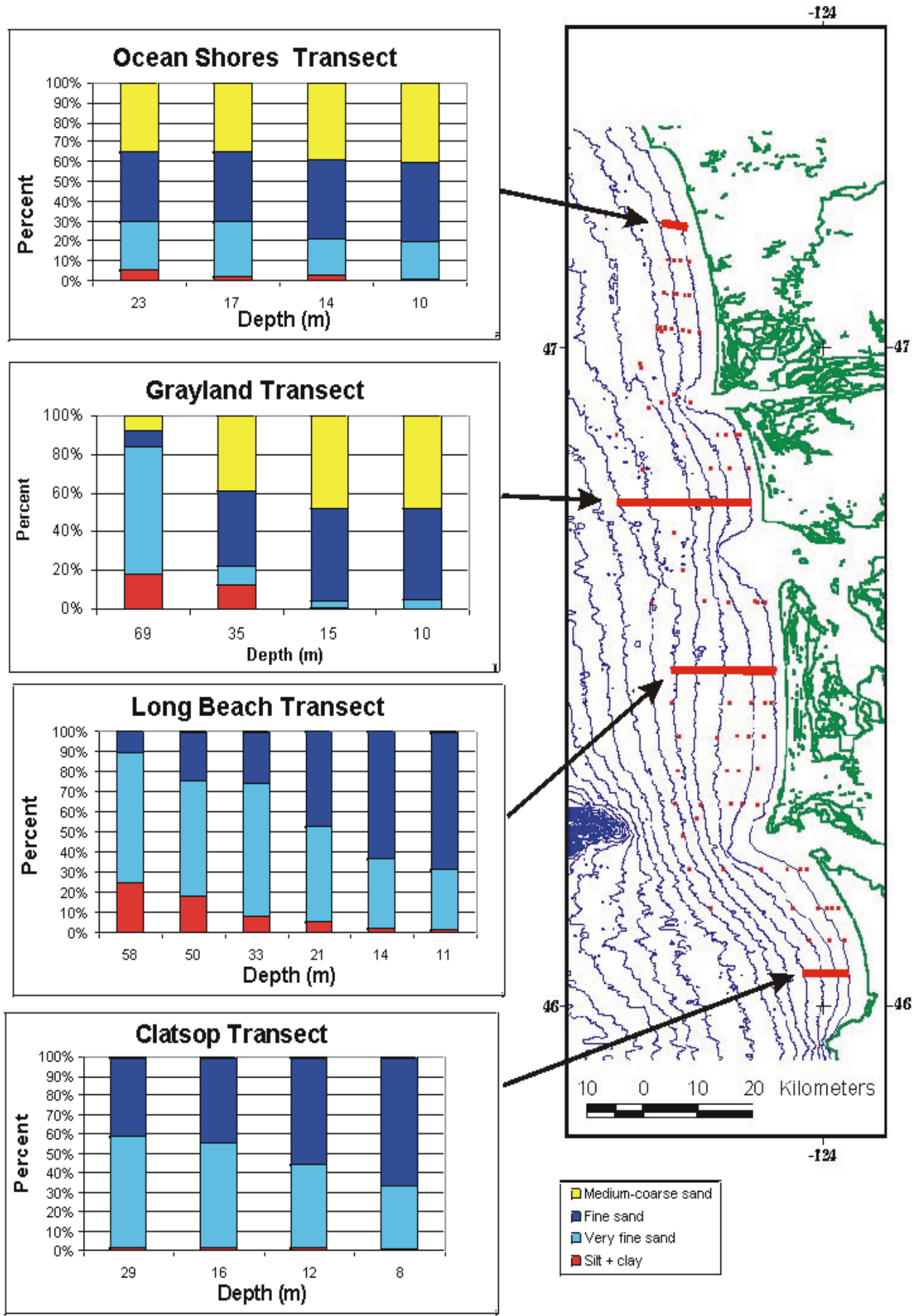

Figure 3. Map showing locations of four grain-size transects across the lower beach face and inner continental shelf. Note that samples from the relict part of the shelf north of the mouth of Willipa Bay are coarser than those from the modern shelf deposit to the south. Grain size of the nearshore samples, particularly on the modern deposit, have a higher fine sand fraction than samples on the inner shelf. The small amount of fine sand in the inner shelf samples suggests that this area is not a major source of sand for the adjacent beach. 


\title{
ROLE OF TIDAL DELTAS IN THE SEDIMENT BUDGET
}

Christopher R. Sherwood, U.S. Geological Survey

Maarten Buijsman, Washington Department of Ecology

Ann Gibbs, U.S. Geological Survey

\begin{abstract}
The ebb and flood-tidal deltas at the entrances to the Columbia River and Grays Harbor contain huge volumes of sand. Because there are frequent surveys near the entrances and bathymetric changes are large, we can compile reasonably reliable sand budgets for the combined ebb- and flood-tidal deltas. The distribution of this sand has changed since construction of the jetties: ebb-tidal deltas have been displaced seaward into deeper water; shallow, migrating channel complexes have been replaced with single, deep channel in each system; sand from flood-tidal deltas has been transferred to estuarine islands and shallow bays; and entrance spits have accreted. Preliminary results show that the volume of sand near the entrance to the Columbia River has increased since the late 1800s. In addition, calculations with UNIBEST indicate that a significant additional amount has been transported away from the entrance in the littoral zone. This suggests that the Columbia River has been a source of sand in historical time, which is important because it means that changes in sand-supply rate must have had, and will continue to have, an impact on the coastal sand budget.
\end{abstract}




\title{
HIGH RESOLUTION GROUND PENETRATING RADAR IMAGING OF LATE PREHISTORIC AND HISTORICAL BARRIER PROGRADATION
}

\author{
Harry M. Jol, University of Wisconsin-Eau Claire \\ Brian Junck, University of Wisconsin-Eau Claire \\ George Kaminsky, Washington Department of Ecology \\ Diana McCandless, Washington Department of Ecology
}

\section{INTRODUCTION}

During summer 1999, high resolution ground penetrating radar (GPR) data were collected at 14 sites in the Columbia River littoral cell (5 sites in the Long Beach sub-cell, 4 sites in the Grayland sub-cell, and 5 sites in the North Beach sub-cell). The sites were selected based on the ability to collect profile data that either provided more details on erosional scarps from earthquake subsidence events, or the details of historical progradation, and preferably, both. Wherever possible, the GPR profiles were taken to span this entire spatial and temporal range in order to obtain a continuous record of the near surface stratigraphy from the late Holocene period (1200 BP or $300 \mathrm{BP})$ on the inland beach ridges to the present day on the beach.

\section{OBJECTIVES}

The major objectives of this work include:

- testing the concept of directly measuring geomorphic signals that span scales from years to millennia to extend the historical record of coastal change into the late Holocene, as well as to densify the time series of historical data over the last century;

- experimenting with higher resolution GPR systems (225 and $450 \mathrm{MHz})$ to attempt to see finer details of the subsurface that may represent seasonal to annual strata as well as detect erosional truncations that may represent El Niño-driven storm events; and

- determining the detailed characteristics of scarps resulting from earthquakeinduced subsidence events, by mapping their 3-D structure and surveying sites with a variety of GPR frequencies to enable the comparison of GPR reflector packages. A specific focus of this research is to gain a better understanding of the time scale associated with the episodic erosion and post-subsidence rebound and morphological adjustment of the upper shoreface to an equilibrium condition.

\section{RESULTS}

Using GPR antennae of 200, 225, and $450 \mathrm{MHz}$, we were able to map the near surface stratigraphy (upper $4-6 \mathrm{~m}$ ) and map the internal structure of the prograded coastal 
barriers in great detail. Topographic data were obtained using real-time kinematic differential global positioning systems (RTK DGPS). The data were collected using a pulseEKKO 1000 GPR system. Step sizes ranged from $0.05 \mathrm{~m}$ to $0.5 \mathrm{~m}$. All data were processed and plotted using pulseEKKO software. Interpretations of the plotted GPR profiles are based on radar facies analysis. These high frequency data sets provide a new basis from which to interpret the morphological evolution of the coastal barriers.

Differences in the GPR reflection packages suggest changes in depositional processes, rates, and periods. Preliminary analysis of high resolution GPR reflection data is allowing reconstruction of shoreline behaviour between time lines obtained from either historical records or various dating techniques (bulk and AMS C14, and optical). Further analysis of the high resolution GPR profiles will allow for comparison of coastal changes since the last earthquake-induced subsidence event of January, 1700 to those since the late $1800 \mathrm{~s}$, when the coast became subject to human intervention (e.g. jetties, dams, irrigation, dredging).

A particularly interesting data set was acquired in the Long Beach sub-cell near Loomis Lake. The GPR transects were collected using $225 \mathrm{MHz}$ antennae along a $7 \mathrm{~m}$ x $30 \mathrm{~m}$ grid with a $0.10 \mathrm{~m}$ step. A 3-D image shows a series of dipping reflections, which are interpreted as an erosional scarp, caused by earthquake activity estimated to have occurred 1200 BP (Figure 1). The 3-D cube was assembled from a series of identical length 2-D GPR profiles running parallel to each other along a $x-y$ grid system. All GPR transects were gathered using a pulseEKKO1000 GPR system and spaced $0.25 \mathrm{~m}$ apart. The 2-D GPR profiles were processed and then interpolated to create 3-D data sets using pulseEKKO software. The GPR image presented shows 3-D imaging to be an effective means of performing detailed stratigraphic analysis of the subsurface features.

\section{CONCLUSIONS}

- The use of high resolution GPR in the Columbia River littoral cell has provided the capability to reconstruct barrier evolution over time scales ranging from years to millennia.

- The locations of several erosional scarps on different GPR profiles throughout the littoral cell coincide with known shoreline positions or dated earthquake events. Some positions were dated at the same time as El Niño events.

- Coastal areas that have undergone rapid progradation (on the order of tens of meters per year) have characteristics (nearly flat topography and subsurface reflectors) that can also be located across barrier sections representing inter-quake periods, suggesting that episodes of rapid progradation have also occurred during prehistoric periods. 


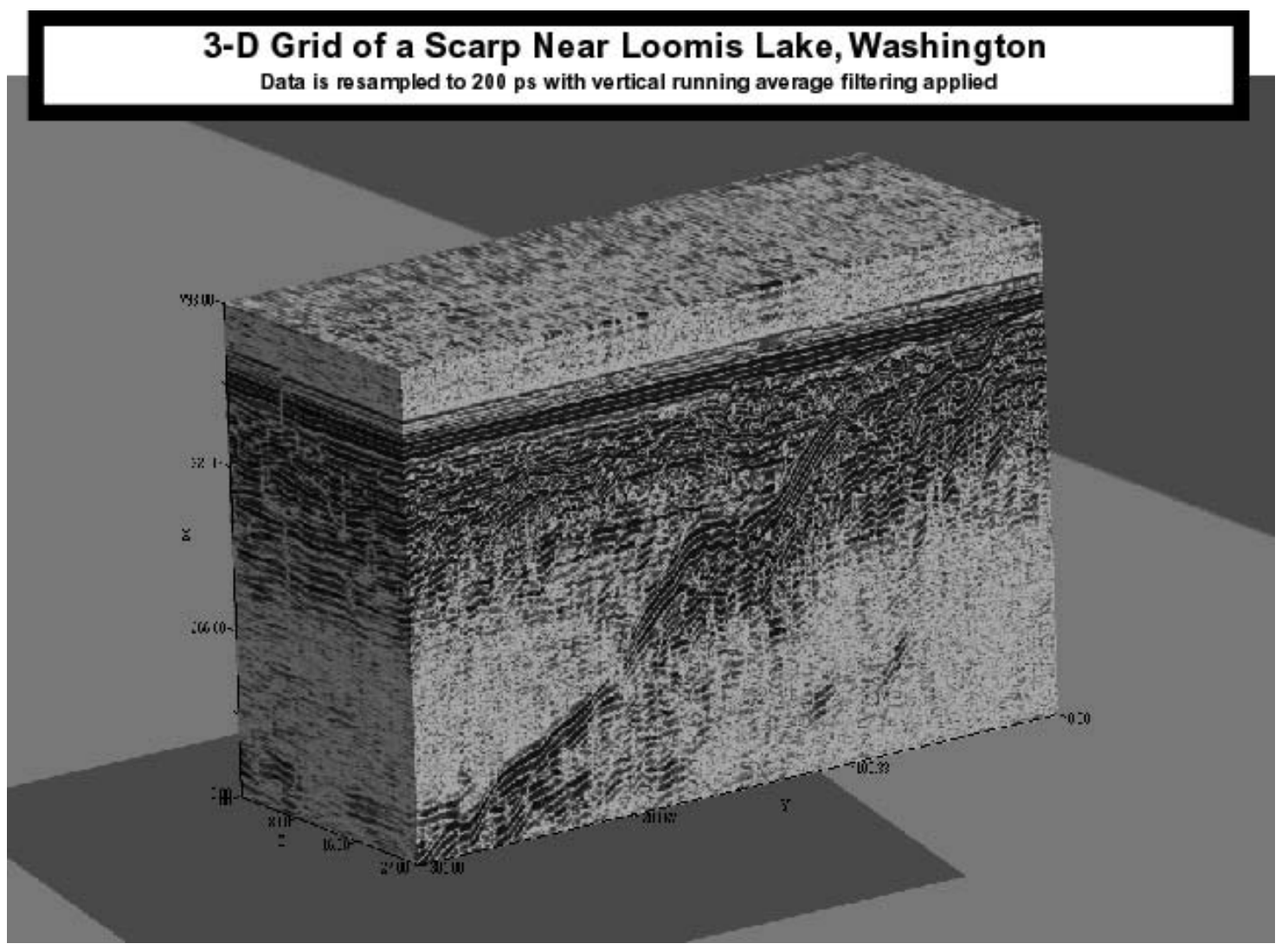

Figure 1. 3-D image of the 1200 BP earthquake-induced subsidence scarp in the Long Beach sub-cell near Loomis Lake. 


\title{
SHORELINE CHANGE MODELING - IN RELATION TO THE SEDIMENT BUDGET
}

\author{
Maarten Buijsman, Washington Department of Ecology
}

\section{INTRODUCTION}

UNIBEST (Delft Hydraulics, 1994), a one-line shoreline change model, was used to study historical shoreline change, to make future predictions, to give information about sediment transport directions and magnitudes, and to give feedback guiding sediment budget calculations.

UNIBEST runs were performed for the last 50 years for the North Beach, Grayland Plains, and Long Beach sub-cells. A regional sediment budget, based on bathymetric and topographic change, acted as a framework for the UNIBEST model runs. Waves were shoaled from the Grays Harbor buoy to the UNIBEST offshore boundary using linear wave theory or with the wave propagation model SWAN (Booij et al., 1999). The tidal currents used in UNIBEST were derived from the hydrodynamic ADCIRC model (Luettich et al., 1992). A sensitivity analysis shows that UNIBEST is most sensitive to directional changes of the wave climate and changes in the sediment fluxes at the northern and southern boundaries of the study area.

\section{RESULTS}

An example of the calibration runs and predictions for the North Beach sub-cell are presented here. UNIBEST runs were performed for the period 1950 to 1995 over the southern 22-km of the sub-cell, assuming closed boundaries in the north and south. In the calibration runs it was assumed that about two-thirds of the 55 million $\mathrm{m}^{3}$ of accreted land came from the Grays Harbor ebb-tidal delta, either from erosion or bypassing, and onethird from the lower shoreface (based on Woxell (1998)). Model results show a net sediment transport to the north. Shoreline change predictions to 2020 are presented in Figure 1. The predictions reveal net erosion of the shoreline within 5-8 km of the Grays Harbor North Jetty and net accretion further to the north. In all cases, the ebb-tidal delta supplied no sand after 1995. The case based on waves shoaled with SWAN and crossshore feeding results in minimum shoreline retreat of $85 \mathrm{~m}$ at the North Jetty. The prediction using waves shoaled with SWAN and no cross-shore feeding shows maximum retreat of $150 \mathrm{~m}$ at the North Jetty. The model results for linear shoaled waves and no feeding are between the model results using waves shoaled with SWAN.

\section{CONCLUSIONS}

Preliminary model results show that over the next two decades, net sediment transport is directed away from the stabilized entrances of Grays Harbor and the Columbia River. In order to maintain the present shoreline configuration sand must be supplied by the ebbtidal deltas and the shoreface (and/or the Columbia River for the Long Beach and Clatsop 
sub-cells). It is important to note that in no case does the shoreline reach equilibrium by 2020. The sediment budget analysis reveals that the erosion of the deltas cannot solely account for the accretion of the barriers. In this analysis the budget was balanced with sediment supplied from the shelf.

\section{REFERENCES}

Booij, N., Ris, R.C., and Holthuijsen, L.H. 1999. A third-generation model for coastal regions, 1. Model description and validation, Journal of Geophysical Research, 104 (C4), pp. 7649-7666.

Delft Hydraulics 1994. UNIBEST, A Software Suite for the Simulation of Sediment Transport Processes and Related Morphodynamics of Beach Profiles and Coastline Evolution, Programme Manual, Delft Hydraulics, Delft, The Netherlands.

Luettich, R.A., Westerink, J.J., and Scheffner, N.W. 1992. ADCIRC: An advanced threedimensional circulation model for shelves, coasts, and estuaries; Report 1, Theory and methodology of ADCIRC-2DDI and ADCIRC-3DL, Technical Report DRP-92-6, US Army Engineer Waterways Experiment Station, Vicksburg, MS, USA.

Woxell, L.K. 1998. Prehistoric Beach Accretion Rates and Long-Term Response to Sediment Depletion in the Columbia River Littoral System, USA, M.S. Thesis, Portland State University, Portland, Oregon, 206 p. 


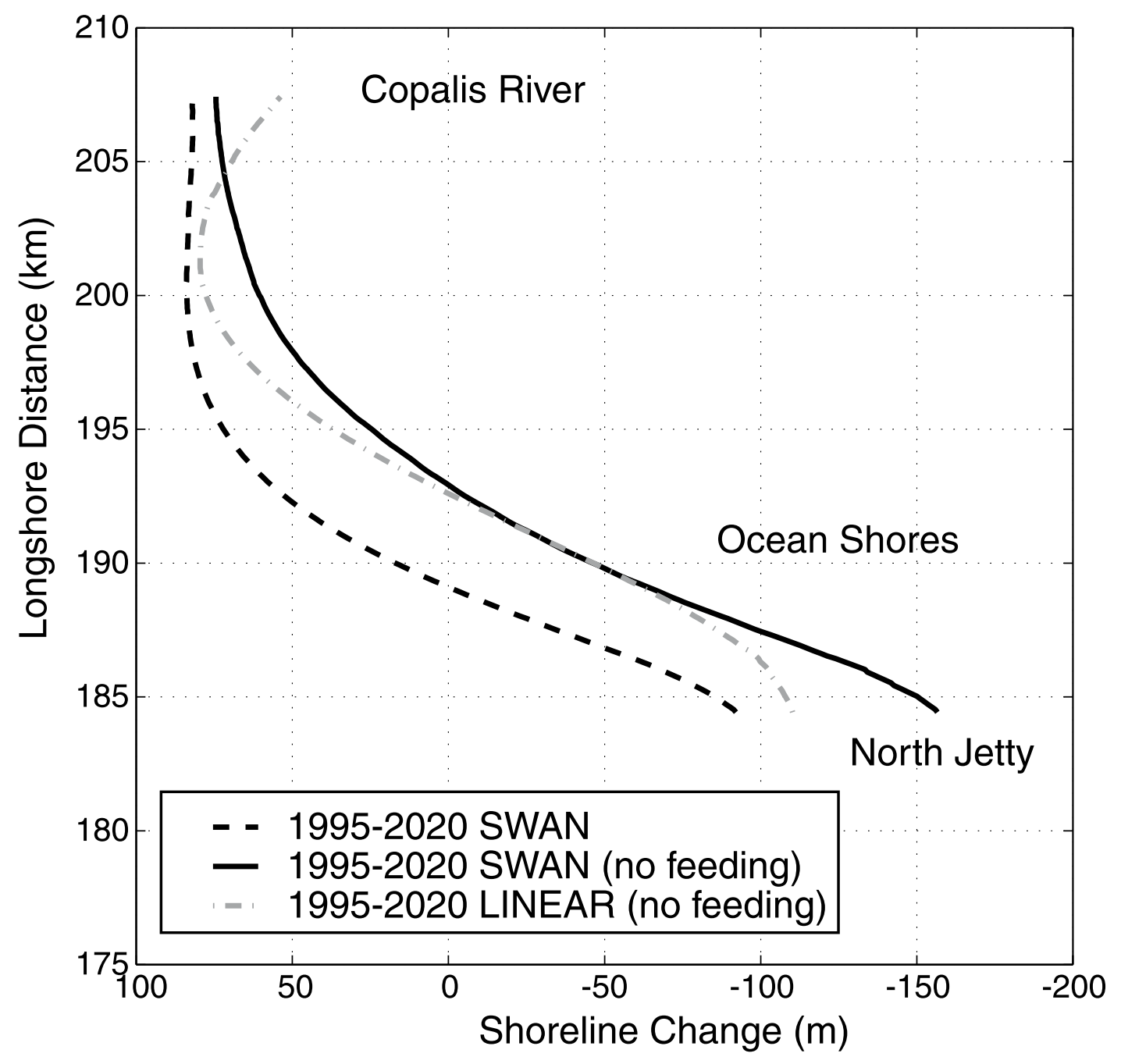

Figure 1. Predicted shoreline change in North Beach sub-cell under various scenarios. 


\title{
CLIMATE CHANGE AND VARIABILITY: CONSIDERING IMPACTS ON COASTAL MORPHOLOGY IN THE COLUMBIA RIVER LITTORAL CELL
}

\author{
Laura Moore, Woods Hole Oceanographic Institution
}

\begin{abstract}
Coastal morphology changes in response to many factors including sediment discharge, wave direction, wave height, frequency of storm events, severity of storm events, storm tracks, and sea-level changes. All of these factors are influenced by changes in regional climate. For this reason, prediction of future changes in coastal morphology along the southwest Washington coast must incorporate an understanding of 1) the relationship between climate variability and coastal morphology and 2) expected future changes in regional climate.
\end{abstract}

Changes in regional climate occur across a range of temporal scales. Instrumental records in the Pacific Northwest allow investigation of these changes over the shorter time scales of a single storm to decades while tree rings and lake cores allow investigation of changes occurring over century and millennial scales, respectively. Coastal morphology also varies across a variety of time scales. However, reliable methods for understanding such changes currently only exist for the shorter temporal scales (Table 1).

Linkages between yearly changes in climate and coastal morphology in the Pacific Northwest have been recognized. For example, El Niño conditions tend to generate elevated sea levels and southwesterly winter storms causing a reversal of longshore sediment transport and severe erosion of south-facing beaches (Komar, 1986). Linkages over longer time scales, however, have not yet been made. Shoreline position information exists back to the 1870s (Kaminsky et al., 1999) and tree ring reconstructions of climate variability date back to approximately 1650 (Ed Miles, personal communication). Investigation of these two records for the southwest Washington region may begin to provide an understanding of linkages between climate change and coastal morphology. However, efforts to establish linkages for the time period of overlap between these two records may be hindered by difficulties in separating the effects of climate variability from the effects of anthropogenic activities that have also impacted coastal morphology throughout the last century.

Extension of linkages between climate change and coastal morphology to the more distant past is desirable and will require additional detailed paleoclimate and paleomorphological reconstructions. Lake cores collected in Washington State (Ed Miles, personal communication), and identification of beach ridges using ground penetrating radar (George Kaminsky, personal communication, Mason and Jordan, 1993) may eventually provide additional useful information with which to establish linkages between climate variability and coastal morphology in southwest Washington. Once established, these linkages can be applied in the prediction of future coastal morphological behavior in the Columbia River littoral cell. 


\section{REFERENCES}

Kaminsky, G.M., Buijsman, M.C., Gelfenbaum, G., Ruggiero, P., Jol, H.M., Gibbs, A.E., and Peterson, C.D. 1999. Synthesizing geological observations and processesresponse data for modeling coastal change at management scale, Proceedings of Coastal Sediments '99, ASCE, pp. 1708-1723.

Komar, P.D. 1986. The 1982-83 El Niño and erosion on the coast of Oregon, Shore \& Beach, April, 1986, pp. 3-12.

Komar, P.D., and Good, J.W. 1989. Longer-term erosion impacts of the 1982-83 E1 Niño on the Oregon Coast, Proceedings of Coastal Zone '89, pp. 3785-3794.

Mason, O.K., and Jordan, J.W. 1993. Heightened North Pacific storminess during synchronous late Holocene erosion of northwest Alaska beach ridges, Quaternary Research, 40, pp. 55-69.

Table 1. Temporal scales of change and tools available to understand changes in the Pacific Northwest.

\begin{tabular}{|c|c|c|}
\hline $\begin{array}{l}\text { Temporal } \\
\text { Scale }\end{array}$ & Tools to Understand Climate Change & Tools to Understand Coastal Change \\
\hline Storm & Instrument Record & Field Monitoring, Aerial Photos \\
\hline Season & “ & “ \\
\hline Year & “ & “ \\
\hline Decade & “ & “ \\
\hline Century & Tree Rings & Historical Maps \\
\hline $\begin{array}{l}1,000 \\
\text { Years }\end{array}$ & Lake Records & $\begin{array}{l}\text { Ground Penetrating Radar- Beach } \\
\text { Ridges? }\end{array}$ \\
\hline $\begin{array}{l}10,000 \\
\text { Years }\end{array}$ & Pollen Records & \\
\hline
\end{tabular}




\title{
CLIMATE EFFECTS ON COLUMBIA RIVER SEDIMENT TRANSPORT
}

\author{
David A. Jay, Oregon Graduate Institute \\ Pradeep Naik, Oregon Graduate Institute
}

\section{THE REGIONAL CONTEXT}

Examination of flow and sediment transport records for five major West-Coast rivers, the Fraser, Columbia, Willamette, San Joaquin and Sacramento, suggest that the non-linear dynamical regime of fluvial sediment transport (sediment transport $\sim Q_{R}{ }^{n}, n>1$, where $Q_{R}$ is river flow) constitutes a potent amplifier of climate fluctuations on interannual and decadal scales. Thus, variations in sediment transport are considerably larger than variations in flow. The primary climate processes involved are:

- the El Niño-Southern Oscillation (ENSO), tracked by the Southern Oscillation Index (SOI, Trenbreth, 1997);

- the Pacific Decadal Oscillation (PDO) defined in terms of the PDO index (Mantua et al., 1997); and

- eastern Pacific Ocean atmospheric pressure (Gerushonov et al., 1999), measured by the California Pressure Anomaly (CPA).

The Columbia and Willamette River basins are centrally located in the area influenced by ENSO climate fluctuations. Therefore, spring freshet flow in the Columbia River and winter flow in the Willamette River respond fairly reliably to ENSO signals. The strongest correlation is with SOI measured during the winter preceding the spring freshet, i.e., during the period of snow accumulation at higher elevation. Fraser River flow is also related to SOI, but the Fraser occasionally exhibits an ENSO response different from the Columbia, depending on storm tracks during a given winter. It is rather more often noted that the ENSO response in California is dramatically different than that in the Pacific Northwest. Thus, El Niño years may be very dry (e.g., 1977) or very wet (e.g., 1981 and 1998) in California. The along-coast gradient in ENSO is related to the atmospheric pressure distribution and described by CPA. CPA is most strongly correlated with flows in California, and its descriptive power declines to the north.

It is perhaps not surprising that the lowest frequency climate phenomenon considered here, the PDO, has the largest spatial scale. The influence of PDO is essentially in phase throughout the region. While the $1977-95$ period was generally warm and dry ("warm PDO") on the West Coast, climate and ocean conditions have since 1995 returned to a "cold PDO" pattern leading to cool, wet winters. This pattern was last seen during 194776 (http://ocs.oce.orst.edu/re-ports/climate_fish.html). How long this pattern will persist is uncertain, and not all years during a cold PDO period will be cool and wet. Still, the last cold PDO endured for almost thirty years, and another cold, wet period occupied most of the period from $\sim 1858-1914$. It is perhaps not un-reasonable to expect that the regime that 
has brought six consecutive winters with above average snow pack may persist for some decades, with important effects on sediment transport in the Columbia and other river systems.

It is important also to consider climate patterns in the context of human use and modification of river systems. The regularity of the annual cycle decreases from North to South, whereas the degree of interannual variability increases. Both features are a reflection of the presence of a significant and fairly stable glacial input or base flow and more regular winter precipitation in the Fraser and the Columbia basins. The demand for water (and consequent degree of regulation and alteration of the systems), however, increases to the south, resulting in larger diversions from the California systems and relatively more acute conflicts over water allocation.

\section{THE COLUMBIA RIVER -- FLUVIAL SEDIMENT SUPPLY}

The Columbia River is the largest of the systems considered in terms of flow and basin area, though its total load and sand transports are less than those for the Fraser (with about half the river flow) and also less than those for the much smaller Eel River. The Columbia provides, however, the longest daily flow record on the US West Coast (1878-date), with annual maximum freshet flows available back to 1858 . The Willamette has daily flow data from 1892-date, with scattered earlier data back to 1878. The Spokane River record begins in 1891. These records allow us to estimate with some degree of confidence annual average Columbia river flow and annual total sediment transport back to 1858 . The broad picture is one of lengthy, alternating periods of above and below average flow (Figure 1). High flows predominated from 1858 to about 1914 (and perhaps for most of 19th Century). Another high-flow period occurred between about 1947 and 1976, and the period since 1995 likely represents the beginning of another wet period. Relatively low flows were observed between 1915 and 1944, and again between 1977 and 1994 . (Another schematization of these data truncates the high-flow period at $\sim 1900$ and begins the low flow period in 1922; the 1901-21 period is then considered neutral.) Flow regulation and diversion have cut the spring freshet by 30-50 percent, though annual average diversion is smaller, about 10 percent (Figure 1). Long-term, climate-induced fluctuations in annual average flow are 15-20 percent and appear to be almost twice as large as present diversion. Interannual flow transfers remain small, reflecting limited storage capacity.

Over the last century, there have been 32 years that can be described as belonging to the moderate to strong El Niño or La Niña categories $(|\mathrm{SOI}|>0.5$; Table 1). Note that La Niña years are more frequent during the cold-PDO phase, and El Niño years during the warmPDO phase. The wettest years in the Columbia basin are typically associated with La Niñas during a cold-PDO phase, and the driest with El Niños during a warm-PDO phase. Cold-PDO La Niña annual average flows exceed their warm-PDO El Niño counterparts by $\sim 25$ percent. Hindcasts suggest a difference in total load of a factor of more than three between these scenarios. Sand transport estimates are even more divergent between coldPDO La Niña years and warm-PDO El Niño years - in this case the difference is a factor of five or six. Although the SOI record extends back into the 1860s, almost as far back as we 
know Columbia River maximum freshet flow, it is impossible to include the pre-1900 period in Table 1, because a PDO index has not yet been defined for the Nineteenth Century.

Human effects on sand and total load transports in the Columbia are difficult to estimate, but any analysis must begin with an understanding of human alteration of the flow hydrograph. Examination of the flow spectrum shows that dam regulation has enhanced high-frequency variability (e.g., through daily and weekly power peaking cycles) and damped low-frequency variability on scales of a few months to $>$ one year (Figures 2 and 3 ). The freshet is also several weeks earlier on average, likely due both to warmer climate conditions and reservoir storage. In dry years, pre-release of water from the reservoir system may cause maximum daily flow at Beaver to occur during a winter freshet, though such freshets are always much briefer than spring freshets. Sediment transport hindcasts can be made for both observed and estimate virgin flows, but these hindcasts are based on limited observations, largely taken during the 1963-70 period. Hindcasts necessarily, therefore, embody assumptions regarding (for fine suspended material) long-term similarity in supply regime. Sand is and always has been available on the bed to be transported, but it is unclear whether dam construction has resulted in large-scale trapping of bed load materials in reservoirs. Nonetheless, Bonneville Dam, the most seaward on the main stem, has been in place since 1937, 36 years before the onset of observations in 1963. We expect, therefore, that development of the dam system since 1970 has had only a limited additional effect on the sand supply to the system. This conclusion is borne out by the rather limited comparisons (pre-1970 vs. post-1970) that can be made (e.g., Figure 4). It also appears that flow regulation rather than diversion has had the largest impact on sediment transport, because of large curtailment of spring freshets and the strong nonlinearity of flow vs. transport relationships (Sherwood et al., 1990; Simenstad et al., 1992).

\section{ESTUARINE INFLUENCE ON TRANSPORT TO THE OCEAN}

Columbia River fluvial sediment supply cannot, of course, be equated with export to the ocean. The tidal-freshwater part of the river acts as a sink for sand and other coarse material. Further deposition occurs in the estuary. Analyses of the fate of radionuclides released from Hanford suggest that about one third of the fine sediment supplied to the system is trapped, primarily in peripheral areas of the estuary (Nittrouer, 1978). A somewhat higher percentage of fines may have been deposited before diking/filling of most of the fluvial flood plain and estuarine marshes. The greatest historical change is likely, however, to have been in the sand budget. The natural mouth of the Columbia River was only $\sim 6 \mathrm{~m}$ deep. Installation of jetties at the mouth and dredging of the navigation channel have caused large changes in depth and greatly reduced the ability of the system to transport material to the sea. Analyses of historical changes in bathymetry suggest that modifications to the entrance pushed a large volume of sand, several hundred million tons, out to sea between 1870 and 1938. An additional large amount of material was deposited in the lower estuary, creating Desdemona Sands (Sherwood et al., 1990). Present channel depths do not appear to allow much sand transport to sea except during the largest spring freshets, when large amounts of sand are also brought into the estuary. Under these 
circumstances, disposal of dredged material on the shelf may constitute the major means of export of sand.

\section{FUTURE RESEARCH}

Several areas for future research are evident. Of highest importance is that daily sediment transport measurements at some suitable location (e.g., Beaver) re-commence -- it is anomalous that sediment transport is not regularly measured on a river as important as the Columbia. These data are needed for a wide variety of scientific and management purposes. Furthermore, the rate of shoaling or erosion of the estuary (a major control on sand transport to the ocean) cannot be inferred with any certainty after the last thorough bathymetric survey of system, completed in 1958. Clearly, a new "wall-to-wall" bathymetric survey is needed, to complement the partial survey completed by the Corps of Engineers in 1982. Also, the actual present and historical transports to the ocean are poorly known. There are a variety of observational, historical and modeling approaches that might be taken to address this problem.

Existing data may also be used for further analyses. One fruitful approach would be to understand the variability of historic sediment transport in terms of flow sources and their seasonality. For example, it is evident that large winter freshets (as occurred in 1861, $1881,1890,1964-65$ and 1996) provide more fine sediment per unit of flow volume than spring freshets. One reason for this is that considerable erosion occurs when snowcovered, poorly vegetated interior basin soils are rapidly thawed by heavy rain. Existing data for sub-basins in the Columbia need to be examined and compared to the longer, more detailed record in the Fraser River to understand the processes (natural and human) involved. Another question concerns the fate of material that is not being transported to the estuary by the present reduced spring freshets. Is it being trapped behind dams, is it remaining immobile on the banks of the lower river, or is it not being supplied to the main stem by tributaries? Furthermore, flow and sediment transport records from the various tributaries need to be analyzed and synthesized, to allow better sediment transport hindcasts. Fourth, it would be highly desirable to define a suitable surrogate for annual average Columbia River flow so that its climatology before 1858 can be studied - perhaps a tree ring index might be defined. Finally, historical archives may yet yield estimates of peak freshet flow for years back to the early 1800s. It would be particularly interesting to know the 1849 peak discharge, which is believed to have been almost as large as that for 1894.

\section{REFERENCES}

Gershonov, A., Barnett, T.P., and Cayan, D.R. 1999. North Pacific Interdecadal Oscillation seen as factor in ENSO-Related North American Climate Anomalies, EOS, 80, pp. 25-29.

Flinchem, E.P., and Jay, D.A. 2000. An introduction to wavelet transform tidal analysis methods, Coastal Estuarine Shelf Science, in press. 
Jay, D.A., and Flinchem, E.P. 1997. Interaction of fluctuating river flow with a barotropic tide: A test of wavelet tidal analysis methods, Journal of Geophysical Research, 102, pp. 5705-5720.

Mantua, N.J., Hare, S.R., Zhang, Y., Wallace, J.M., and Francis, R.C. 1997. A Pacific interdecadal climate oscillation with impacts on salmon production, Bulletin of the American Meteorological Society, 78, pp. 1069-1079.

Nittrouer, C.A. 1978. The process of detrital sediment accumulation in a continental shelf environment: an examination of the Washington shelf, Ph.D. dissertation, University of Washington Oceanography Department, 243 p.

Simenstad, C.A., Jay, D.A., and Sherwood, C.R. 1992. Impacts of watershed management on land-margin ecosystems: the Columbia River Estuary as a case study, In: R. Naimen, ed., New Perspectives for Watershed Management - Balancing Long-term Sustainability with Cumulative Environmental Change, Springer-Verlag, New York, pp. 266-306.

Sherwood, C.R., Jay, D.A., Harvey, R.B., Hamilton, P., and Simenstad, C.A. 1990. Historical changes in the Columbia River estuary, Progress in Oceanography, 25, pp. 271-297.

Trenbreth, K.E. 1997. The definition of El Niño, Bulletin of the American Meteorological Society, 78, pp. 2771-2777. 


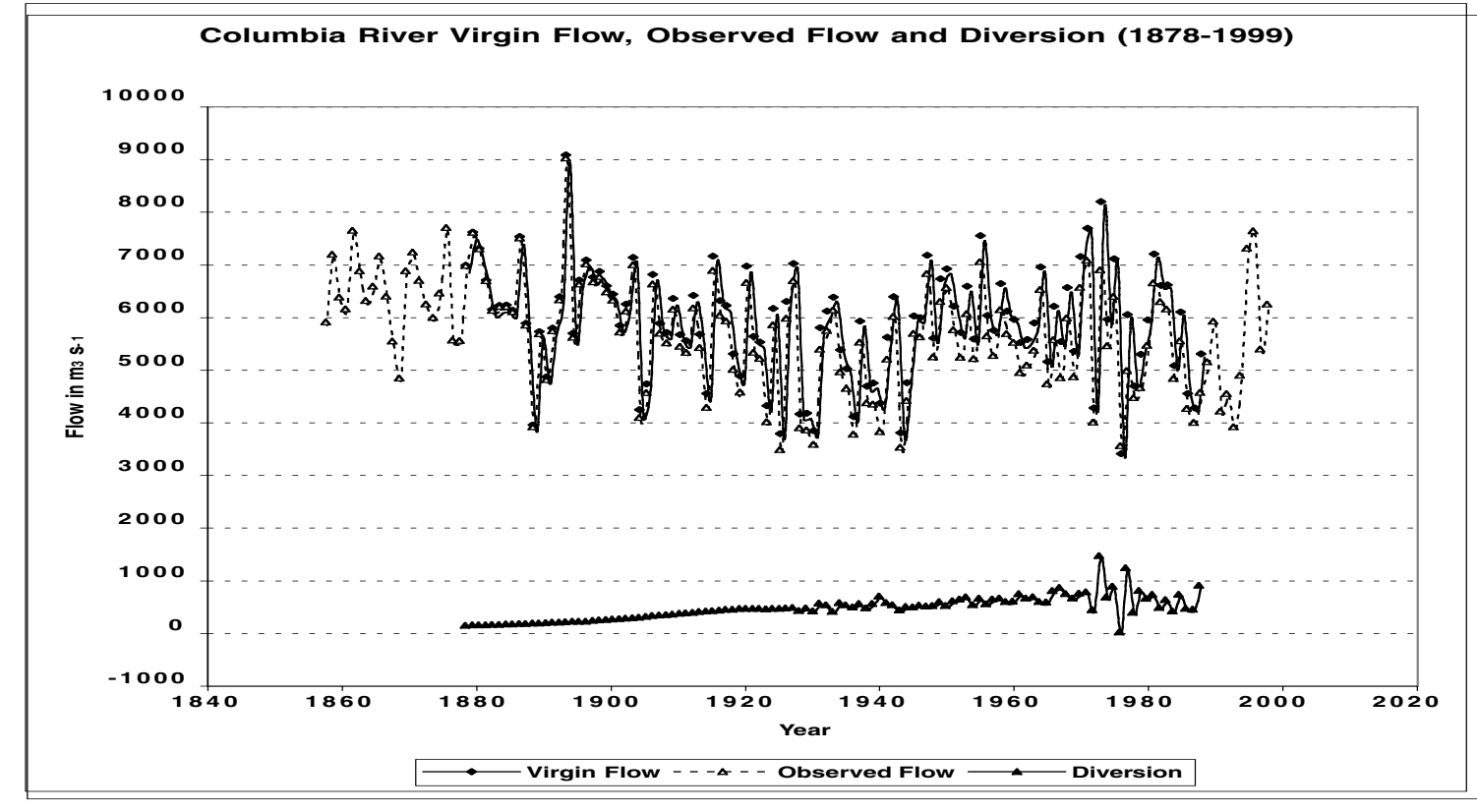

Figure 1. Columbia River annual average observed flow, estimated virgin flow (i.e., the flow that would have been observed without diversion or regulation), and flow diversion at bottom. Annual flows for $\mathbf{1 8 5 8 - 7 8}$ are estimated from observed annual average daily. Diversion before 1929 is estimated from the area irrigated, using the annual irrigation cycle observed in 1929-34. Diversion for 1929 and later years is derived from irrigation records. Note the return to very high flows after 1995. 


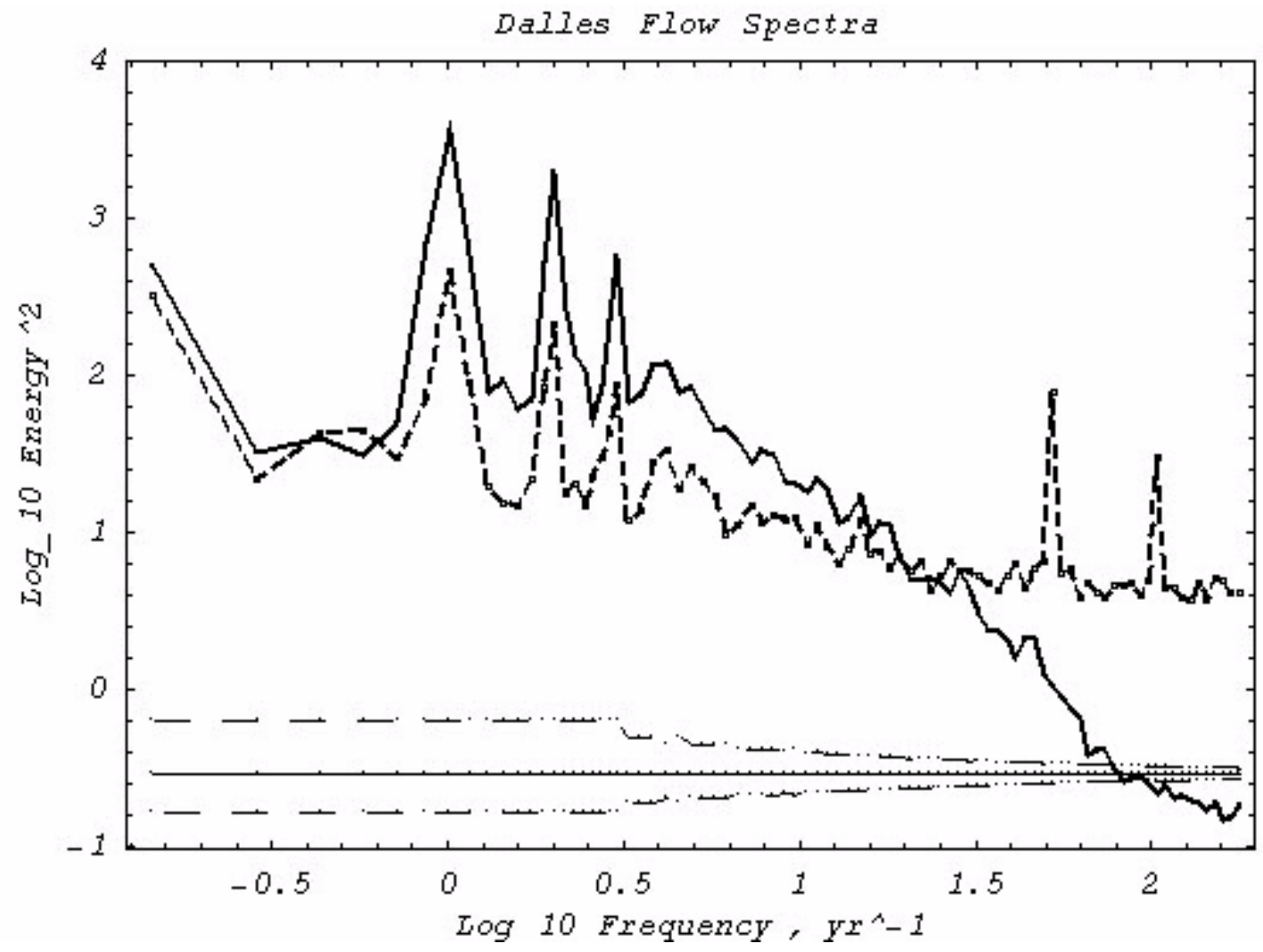

Figure 2. Power spectra of the first 27 years of the daily Columbia River flow record $(-)$ from 1878-1905 and the last 27 years (- - from 1970-97. It is evident that the undisturbed flow spectrum had much less energy at high frequencies than the regulated flow and much more in the range from $\sim 2$ yrs to $\sim 1$ mo. The distinct peaks in the regulated flow at $7 \mathrm{~d}$ and harmonics thereof result from the weekly power peaking cycle. The $95 \%$ significance estimates are shown at the bottom (- . - .). 


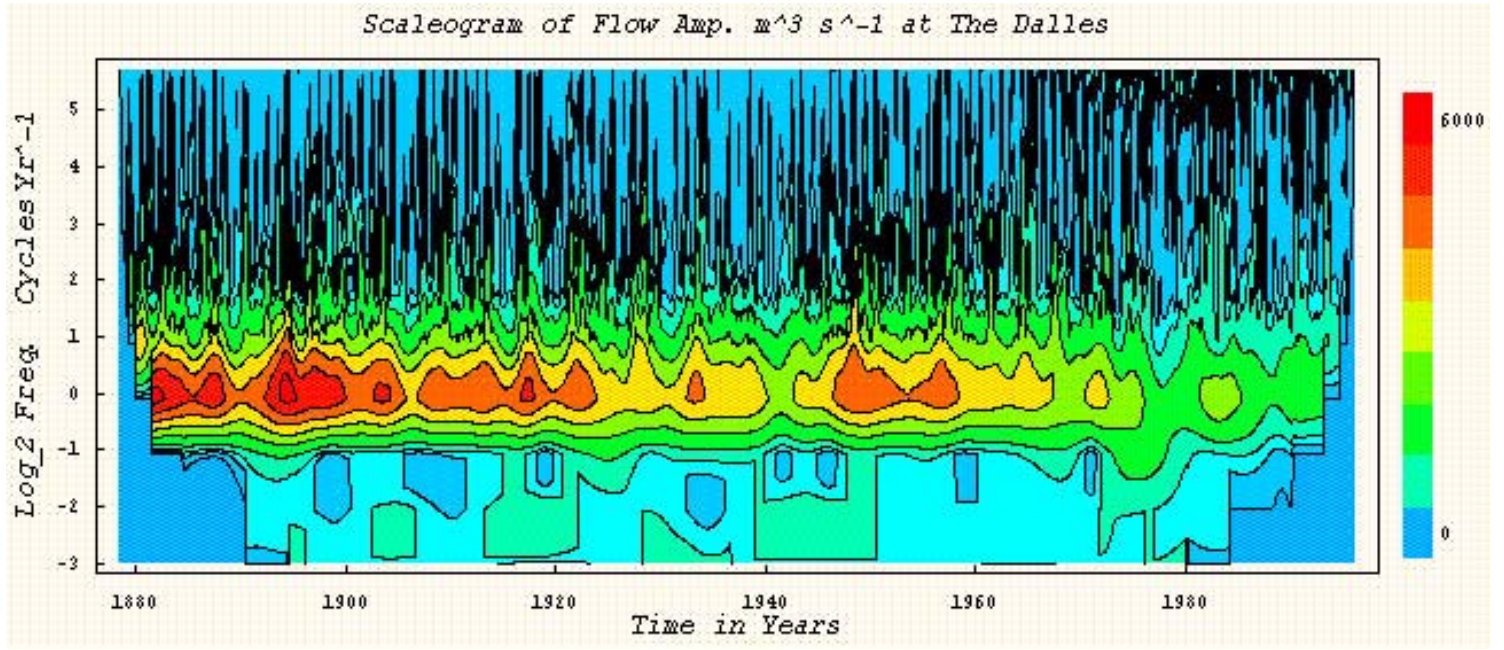

Figure 3. Amplitude of Columbia River flow fluctuations $\left(\mathrm{m}^{3} \mathrm{~s}^{-1}\right)$ at The Dalles, Oregon, 1878-1996, as a function of date (x-axis) and log (base 2) of frequency in cycles $\mathrm{yr}^{-1}$ (y-axis), as derived using continuous wavelet transform (CWT) analysis (Jay and Flinchem, 1997; Flinchem and Jay, 2000). Most of the larger freshets in the record occurred before 1900. The annual flow cycle $\left(1\right.$ cycle $\left.\mathrm{yr}^{-1}, \log _{2} 1=0\right)$ and all fluctuations with periods between 3 mo and 2 yr have been damped by flow regulation and to a lesser extent by climate change. High frequency fluctuations (periods of 1-7 d) were naturally weak, but have been greatly enhanced by daily and weekly power-peaking cycles (upper right-hand corner). The Dalles has the longest gauging record on the west coast of the US. River flow, and associated sediment delivery, are the single most important drivers for changes in the system. 


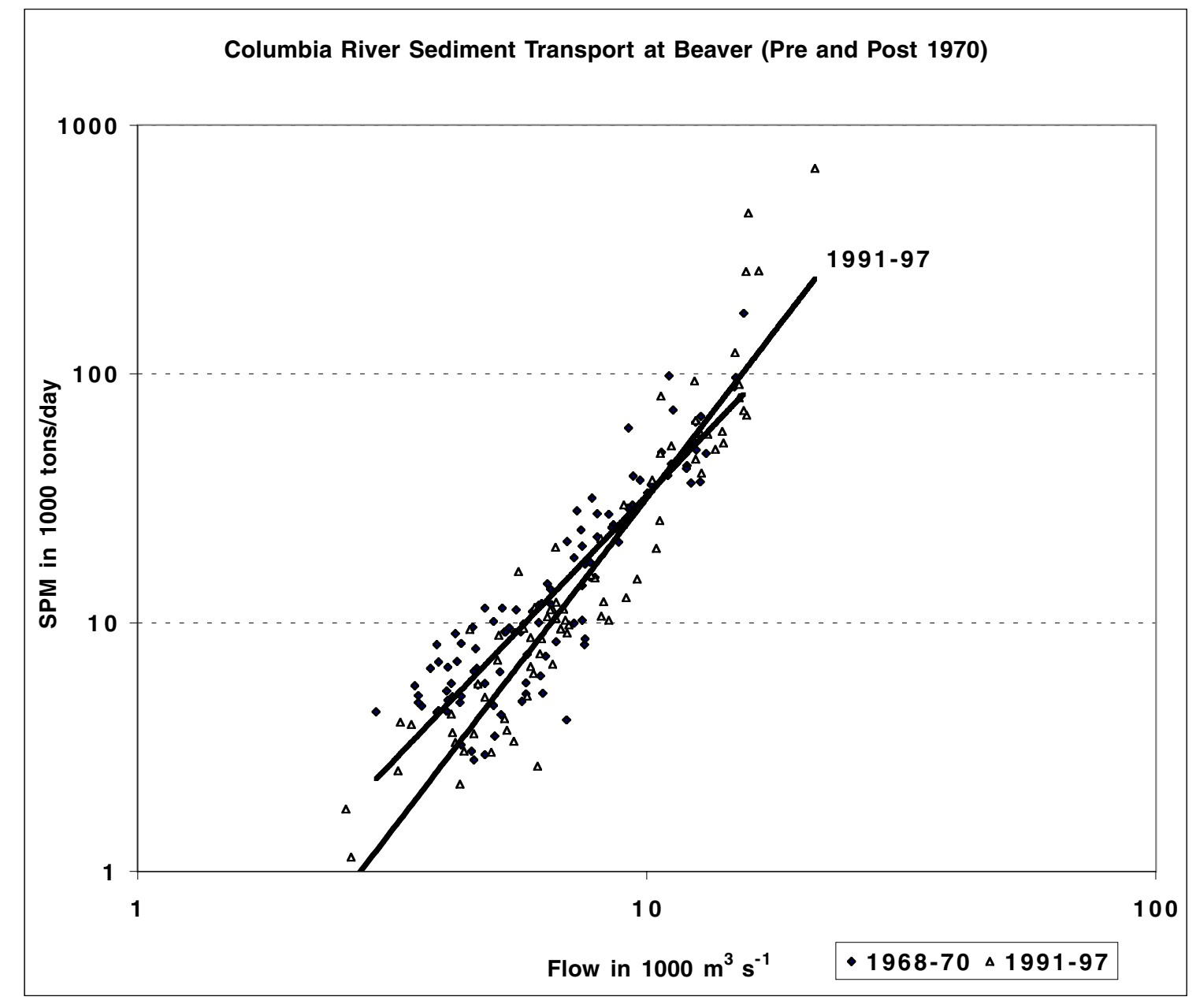

Figure 4. Regression lines for total daily sediment transport at Beaver for 1968-70 and 199197. The slopes of the lines are not statistically distinguishable. 
Table 1. Columbia and Willamette River Flow and Sediment Supply*

\begin{tabular}{|c|c|c|c|c|c|c|}
\hline & $\begin{array}{l}\text { La Niña } \\
\text { Cold } \\
12 \text { years }\end{array}$ & $\begin{array}{l}\text { La Niña } \\
\text { Warm } \\
3 \text { years }\end{array}$ & $\begin{array}{l}\text { EI Niño } \\
\text { Cold } \\
5 \text { years }\end{array}$ & $\begin{array}{l}\text { El Niño } \\
\text { Warm } \\
12 \text { years }\end{array}$ & $\begin{array}{l}\text { Long- } \\
\text { Term } \\
\text { Average }\end{array}$ & $\begin{array}{l}n \text { in } \\
\mathbf{Q}_{\mathbf{R}}{ }^{n}\end{array}$ \\
\hline \multicolumn{7}{|c|}{$\begin{array}{l}\text { Percent of Long-Term Mean and 95\% } \\
\text { Confidence Limits }\end{array}$} \\
\hline \multicolumn{7}{|l|}{$\underline{\text { Columbia River }}$} \\
\hline The Dalles -- Flow & $111 \pm 9$ & $93 \pm 17$ & $95 \pm 9$ & $85 \pm 8$ & $\begin{array}{l}5,430 \\
\mathrm{~m}^{3} / \mathrm{s}\end{array}$ & \\
\hline Vancouver -- Total Load & $134 \pm 37$ & $63 \pm 45$ & $67 \pm 26$ & $41 \pm 20$ & $\begin{array}{l}12.8 \times 10^{6} \\
\mathrm{mt} / \mathrm{yr}\end{array}$ & $\sim 2.5$ \\
\hline Vancouver -- Sand & $109 \pm 43$ & $92 \pm 72$ & $51 \pm 35$ & $18 \pm 6$ & $\begin{array}{l}5 \times 10^{6} \\
\mathrm{mt} / \mathrm{yr}\end{array}$ & $\sim 4$ \\
\hline \multicolumn{7}{|l|}{ Willamette River } \\
\hline Flow & $119 \pm 15$ & $93 \pm 22$ & $114 \pm 23$ & $81 \pm 13$ & $976 \mathrm{~m}^{3} / \mathrm{s}$ & \\
\hline Total Load & $121 \pm 37$ & $88 \pm 47$ & $86 \pm 14$ & $58 \pm 18$ & $\begin{array}{l}1.82 \times 10^{6} \\
\mathrm{mt} / \mathrm{yr}\end{array}$ & $\sim 1.7$ \\
\hline \multicolumn{7}{|c|}{$\begin{array}{l}\text { * PDO index is defined only after } 1900 \text {. Therefore, the percentages are compiled for the } 1900- \\
99 \text { period. The long-term averages are, however, for the } 1878-1999 \text { period for the Columbia } \\
\text { and } 1891-1999 \text { for the Willamette. Flows are compiled from U.S. Geological Survey daily } \\
\text { observations. Sediment transports are hindcast, based on U.S. Geological Survey observa- } \\
\text { tions for the } 1962-70 \text { period. }\end{array}$} \\
\hline
\end{tabular}




\title{
STATUS OF CORPS' PROJECTS: SOUTHWEST WASHINGTON COAST 1999- 2000
}

Eric Nelson, U.S. Army Corps of Engineers

\begin{abstract}
Over the past year, the Seattle District of the U.S. Army Corps of Engineers has either initiated or completed over $\$ 15$ million in maintenance of navigation structures at the entrance to Grays Harbor. A 1,900-foot extension to the Point Chehalis revetment was completed in March 1999 at a cost of \$2,600,000. In April and May, 230,000 cubic yards of maintenance dredged material was utilized to place beach nourishment material on top of, and seaward of the structure, at a cost of approximately $\$ 1,000,000$. In September 1999 two contracts totaling $\$ 13,800,000$ were awarded for the maintenance of the south jetty. The South Jetty Repair Project will reinforce the east end of the south jetty, including construction of a wave deflection mound. The South Jetty Rehabilitation Project will bring the inner 2,300 feet of the structure up to the same structural condition as the outer 3,000 feet that was rebuilt in 1967. On the north side of the harbor, plans and specifications for the North Jetty Rehabilitation Project are being completed at this time. Construction may begin as early as this winter. In addition, the Ocean Shores Storm Damage Reduction Reconnaissance Study is in the final stages of completion. This study will determine if there is a federal interest in addressing the shoreline erosion problems being faced by the city in the area adjacent to the north jetty.
\end{abstract}

The Seattle District is funding two major numerical model investigations by the Waterways Experiment Station. The Willapa Bay Bar Channel-Stability Study was initiated in October 1998 and was completed at the end of October. The $\$ 2,000,000$ Willapa study was intended to determine if a safe, reliable channel can be constructed and maintained at the entrance to Willapa Bay. The study significantly narrowed the possible alternatives, and a final report is being prepared. Copies of the report may be obtained by contacting the project manager, Hiram Arden at hiram.t.arden@usace.army.mil. A second model investigation is being carried out in Grays Harbor. This project takes advantage of the modeling techniques and field instrumentation that were developed during the Willapa study. The results from this model investigation will support the future operation and maintenance of the federal navigation channel. 


\title{
SHORELINE CHANGE NEAR GRAYS HARBOR ENTRANCE AND SOUTH JETTY TESTING UPDATE
}

\author{
David Simpson, Pacific International Engineering
}

\section{INTRODUCTION}

The 1998-99 winter wave conditions were exceptionally energetic. The largest storm of the winter occurred on March 3, 1999 and lasted 14 hours as determined from records of the Grays Harbor buoy, and had significant wave heights exceeding 9.8 meters. That significant wave height exceeds that calculated for the 100-year return period for that buoy. Very large wave events also occurred in November 1998 and February 1999. During the March 3 storm the observed tidal elevation at the Toke Point gauge registered water levels of $4.3 \mathrm{~m}$ feet above MLLW, or $1.3 \mathrm{~m}$ above the predicted level. Combinations of this water level and the storm waves usually produce significant beach change.

\section{SOUTH BEACH}

Shoreline change data for South Beach are more limited than at the time of last year's presentation. The program of land surveys of South Beach that had been carried out by Grays Harbor College was discontinued in 1998. Aerial photography is continuing and on-site observations have been made there. The beach and backshore appear to be fairly stable. A site visit on September 23, 1999 at the time of a 3-meter tide stage documented a quite flat beach about $100 \mathrm{~m}$ wide near the South Jetty. No patches of gravel or shell were observed; the surface sediment was sand. It appeared that a lot of sand had moved onto the lower part of the subaerial beach.

Although a historically high water level and the wave height of record occurred simultaneously in the winter of 1998-99, the average retreat rate continued to slow at the northern part of South Beach. The beach appears to be filling and rising in elevation at the back beach. Comparing aerial photographs of the South Beach and Half Moon Bay areas, the following changes can be quantified:

1) the width of the breach fill, measured between Half Moon Bay and the Pacific beach shoreline has reduced from $360 \mathrm{~m}$ as originally constructed in 1994 to about $125 \mathrm{~m}$ in 1999. Between July 1998 and May 1999, the amount of narrowing was $12 \mathrm{~m}$. About half of that loss occurred from the Half Moon Bay side.

2) the bluff retreat of the breach fill from just the Pacific side was about $7 \mathrm{~m}$, as measured at the transect named "Pole" in the 1998 South Beach Stabilization Study. This is a reduction from the $9.8 \mathrm{~m}$ (32 feet) of surveyed change between 1997 and 1998 .

3) the bluff retreat at the transect named "View," at the park's viewing stand, was undetectable from photographs of the scale 1" $=200$ '. The change of bluff location here, as measured by surveys, was 2 meters between the summers of 1997 and 1998 . 


\section{NORTH BEACH}

North Beach at the southern end of Ocean Shores showed surprising stability of the bluff position in the winter 1998-99, although the beach has undergone some raising and lowering near the north jetty. The reduced level of damage to the North Beach bluff can be attributed to sand accumulation in the summer and early winter at the north jetty and extending northward about $400 \mathrm{~m}$. Beach level observations can be made relative to the temporary wave bumper structure. During the early winter of 1998-99, sand accumulated at the northern end of the structure, covering it to within a meter of the top at the northern end. At the southern end, only the lower tier of rocks was covered, and the beach lowered slightly, with the MHHW contour moving landward about $10 \mathrm{~m}$ in the first half of the winter. In the latter part of the winter, the MHHW contour moved landward about $15 \mathrm{~m}$ at both the north and south end of the structure.

The MHHW contour at the northern tip of the structure migrated seaward $35 \mathrm{~m}$ by the end of October. The sand level is somewhat higher in front of the structure than directly adjacent to it, forming a steeper beach there than at distances away from it. The model of declining rate of shoreline retreat that was developed in the Ocean Shores Beach Stabilization Study in 1997, indicated a retreat rate of about $10 \mathrm{~m}$ per year at this time. The variability in elevation of the upper beach makes it hard to compare average beach movement with a predicted value. The bluff retreat at locations lateral to the temporary structures, however, is lower than expected. Measurements from aerial photographs show about 3 meters of bluff retreat at the northern end of the rock structure, and about 1 meter of retreat at a distance $120 \mathrm{~m}$ to the north from 1998 to 1999.

\section{SOUTH JETTY}

A study of jetty permeability was conducted in early 1999 , to determine if sand was being driven in either the southerly or northerly direction through the South Jetty by waves and currents. Instruments to measure currents, waves, and sediment concentration, as well as historical photographs were employed in the study. The conclusion was that the jetty is most likely not permeable to sand movement in the zone from the shoreline seaward to the seaward extent of the surf zone.

The South Beach Stabilization Study that PI Engineering completed in 1998 included the wave refraction mound as one component of options for reducing erosion risk. PI Engineering interacted with the Corps of Engineers WES in testing configurations of the mound. A mound shape that was determined to perform well enough to proceed with design was sloped at 7 horizontal to 1 vertical and was nearly conical in shape. Photographs and video of physical model tests of wave refraction are available. The Corps of Engineers Seattle District designed and permitted this structure. Construction is under way.

\section{SUMMARY}

Predictions of amounts of shoreline position change had previously been made for South Beach and North Beach at Grays Harbor. In the 1998-1999 storm season, shoreline retreat 
distance at South Beach continued to decline, as predicted. Position of the MHHW contour line at North Beach had great cross-shore variability because of a large recent accumulation of sand at the north jetty and the subsequent reworking of that sand by waves and currents. The retreat of the bluff edge (outside the zone of the shore protection structures) in the past year has been about one-third of that predicted to occur, based on the model of bluff retreat developed in the 1997 study. Questions of continuity of northward sand transport at the Grays Harbor south jetty were investigated with field and office studies. Conclusions are that the south jetty is most likely not permeable to sand transport. 


\title{
PROCESS BASED TIDAL AND ESTUARINE INLET MODELING
}

\author{
Marcel Stive, Delft Hydraulics
}

\begin{abstract}
Despite significant scientific progress in process-based descriptions of two- and threedimensional coastal processes, there exists a sincere concern about the validity of the integrated application for complex situations. One class of such complex situations concerns tidal basins and estuarine inlets. Their ebb- and flood-tidal deltas display a strong variability with important impacts on the adjacent coasts. Also, inlet dynamics play an important role in the fundamental issue of assessing the source or sink function of the connected basin for the coastal sediment budget. One way to validate the role and applicability of process-based models is checking their performance when confronted with observed evolutions. Results of such validation exercises for tidal and estuarine inlets in the Netherlands will be presented. This might aid discussions on the possible role of this type of modeling for the Southwest Washington Coastal Erosion Study.
\end{abstract}




\title{
SWAN WAVE MODEL SENSITIVITY TO VARIATION IN MODEL FORMULATION
}

\author{
Meg Palmsten, University of South Florida
}

\begin{abstract}
Delft University of Technology's SWAN (Simulating Waves Nearshore) Model was implemented to study wave propagation on the inner continental shelf as part of the Southwest Washington Coastal Erosion Study. SWAN has significant flexibility. The modeler may often choose amongst several formulations in describing the physical processes influencing waves or may also choose not to model a process at all. The purpose of this study was to document a suite of over one hundred model runs performed to measure the sensitivity of SWAN to choice of formulation (bottom friction, whitecapping, linear and exponential wave growth), use of triads, form of boundary conditions, wind speed and direction, directional and frequency resolution, and method of quadruplet computation. Three wave states corresponding to waves observed off the Washington coast in fall 1998 were used in this study.
\end{abstract}

Results were analyzed by calculating mean percent difference in wave height and mean difference in wave direction over the study area and in three smaller "coastal" areas bounded by the $15 \mathrm{~m}$ and the $40 \mathrm{~m}$ isobaths. Significant wave height was roughly 2 percent greater in coastal areas when no model wind was present than when a light following wind was blowing. Turning whitecapping off increased significant wave height up to 7 percent in coastal areas and 2-4 percent over the study area. Wave height varied up to 4 percent due to choice of wave growth term. Order of magnitude change in wave growth term coefficients resulted in 3 percent difference in wave height. Model results showed up to a 5 percent difference in wave height in coastal areas due to choice of bottom friction formulation and changes in bottom friction coefficients. Differing the form of boundary conditions resulted in $0-3$ percent changes in wave height. Variation in directional and frequency resolution resulted in differences in wave height of less than 2 percent. SWAN wave height was extremely insensitive to several parameters: use of a linear wave growth term, quadruplet numerics, and changes in triad coefficients. SWAN wave direction usually varied less than 3 degrees due to changes in model parameters. The results of this suite of SWAN model runs will be compared with field data to improve wave modeling on Washington's inner continental shelf. 


\title{
PRELIMINARY SWAN MODELING BASED ON CLIMATOLOGICAL DATA
}

Kurt Hanson, U.S. Geological Survey

\begin{abstract}
Wave modeling efforts in the southwest Washington coastal region are needed as part of the study of sediment transport. For a complete understanding, the modeling must encompass as much of the temporal variability in wave states as possible. This temporal variability is assessed by generating a climatology from observational wave data but there are various ways of computing a climatology. Data describing several different characteristics of waves may be available (as in our case), and some or all of these data types might be incorporated in the climatology. A method must also exist for extracting events from this climatology for use in the model. Traditionally, events are ranked by some definition of importance, which is subject to various interpretations. These approaches to developing a climatology are discussed in this presentation. Furthermore, in this region, the buoys used for computing climatologies are located shoreward of the offshore boundary of the model. A strategy is developed for determining the link between these locations. Preliminary wave model results are then reported in order to identify some salient characteristics of wave transformation in this region.
\end{abstract}




\section{GRAYS HARBOR WAVE REFRACTION EXPERIMENT}

Guy Gelfenbaum, U.S. Geological Survey

Chris Sherwood, U.S. Geological Survey

Kurt Hanson, U.S. Geological Survey

Peter Howd, University of South Florida

Meg Palmsten, University of South Florida

\section{INTRODUCTION}

The magnitude and direction of longshore sediment transport along the beaches of southwest Washington and northwest Oregon, and ultimately shoreline change resulting from gradients in transport, are very sensitive to the magnitude and direction of incoming waves (Buijsman et al., this volume; Gelfenbaum and Kaminsky, 1999). Unfortunately, the historical record of waves measured off the coast of Washington is relatively short, and the record of directional waves is even shorter. The Grays Harbor wave buoy has been collecting wave direction data since 1993. Additional directional wave data were collected off Long Beach peninsula for only a few years in the early 1990s. These records alone are not sufficient to use in models of shoreline change for two reasons. First, shoreline change modeling requires comparison with historical records. In southwest Washington, these comparisons cover historical shoreline change from the 1950s to the 1990s. Because wave data do not exist for that entire period, wave models are employed to provide the proper input. Secondly, the offshore wave buoys are not co-located with the depth of closure, which is the offshore boundary for the longshore transport calculations. Therefore, the waves must be shoaled and refracted from the offshore buoys into the depth of closure. To do this, we use a wave model to predict the transformation of the waves from the buoy into shallower depths. Existing wave models are essentially untested for the Washington shelf. In order to test, and calibrate these wave models, the Study is conducting a wave refraction and shoaling experiment off the entrance to Grays Harbor, WA.

The goals of the Grays Harbor wave experiment are 1) to provide field data to calibrate and verify wave refraction and shoaling models, and 2) to provide field measurements of waves, currents, and sediment transport around an ebb-tidal delta. The experimental design to meet these goals is shown is Figure 1. Six instrumented tripods are deployed around the Grays Harbor ebb-tidal delta. The locations of the tripods were chosen to optimize differences in wave conditions (height, period, and direction) among the locations. The wave model SWAN was used to conduct pre-experiment predictions to assist in the selection of sites (Palmsten, this volume; Hanson, this volume). Table 1 lists the instruments that are mounted on each of the tripods and the sampling schemes for each of the instruments. Figure 2 shows the instrumented tripods deployed at Sites MS, ND and NS.

The instruments were deployed on October 1st and 2nd, 1999. They are scheduled to be collecting data for a total of 10 weeks, with a mid-deployment recovery after 5 weeks to 
change batteries and download data. The fall and early winter seasons were chosen for the experiment to provide the best opportunity to measure a variety of wave conditions. Recent historical data suggest that during this season there are times when the waves will be approaching from the northwest and other times when the waves will be approaching from the southwest. These variable conditions will offer the best opportunity to calibrate the wave model.

Three of the tripods (ND, NS, and MS) were recovered on November 2, 1999. Figure 3 shows a time series of mean values of significant wave height, water depth, current speed near the bed, and suspended-sediment concentration from site ND. During the first month of the experiment a variety of wave conditions were measured, including a large storm around October 26, when waves heights exceeded $8 \mathrm{~m}$.

These data will be analyzed for wave statistics, including wave direction, and used to test and calibrate the wave models.

\section{ACKNOWLEDGEMENTS}

We would like to thank Keith Kurrus and crew from Evans-Hamilton, Inc. for their excellent work in deploying and recovering the instruments. We would also like to thank the skipper of the Tricia Rae, Terry Larson, for his assistance. Finally, we acknowledge Daryl Slocum of SonTek Inc. for his assistance, and Laura Kerr for her help in this project.

\section{REFERENCES}

Buijsman, M.C. this volume. Shoreline change modeling - In relation to the sediment budget, Southwest Washington Coastal Erosion Workshop Report 1999, U.S. Geological Survey Open-File Report.

Gelfenbaum, G., and Kaminsky, G. M. (editors) 1999. Southwest Washington Coastal Erosion Workshop Report, 1998, U.S. Geological Survey Open-File Report 99-524, 182 p.

Hanson, K. this volume. Preliminary SWAN modeling based on climatological data, Southwest Washington Coastal Erosion Workshop Report 1999, U.S. Geological Survey Open-File Report.

Palmsten, M. this volume. SWAN wave model sensitivity to variation in model formulation, Southwest Washington Coastal Erosion Workshop Report 1999, U.S. Geological Survey Open-File Report. 
Table 1. Grays Harbor wave refraction experiment deployment 1, instruments and settings.

\begin{tabular}{|c|c|c|c|c|c|c|}
\hline & Station ND & Station NS & Station MD & Station MS & Station SD & Station SS \\
\hline Deployment No. & 1 & 1 & 1 & 1 & 1 & 1 \\
\hline Date Deployed & 10/1/99 & 10/1/99 & $10 / 2 / 99$ & 10/1/99 & $10 / 2 / 99$ & $10 / 2 / 99$ \\
\hline $\begin{array}{l}\text { Time Deployed } \\
\text { (GMT) }\end{array}$ & 1937 & 1900 & 1953 & 2055 & 2040 & 2057 \\
\hline Latitude (N) & $47^{\circ} 00.768$ & $47^{\circ} 00.841$ & $46^{\circ} 57.059$ & $46^{\circ} 56.853$ & $46^{\circ} 52.411$ & $46^{\circ} 53.507^{\prime}$ \\
\hline Longitude (W) & $124^{\circ} 14.772$ & $124^{\circ} 12.299$ & $124^{\circ} 14.676$ & $124^{\circ} 13.089$ & $124^{\circ} 12.363$ & $124^{\circ} 11.171^{\prime}$ \\
\hline $\begin{array}{l}\text { Approx Water Depth } \\
\text { (m) }\end{array}$ & 22.92 & 10.82 & 22.28 & 11.00 & 22.34 & 13.23 \\
\hline $\begin{array}{l}\text { ADP Serial No. } \\
\text { Druck Pressure } \\
\text { Sensor? }\end{array}$ & $\begin{array}{l}\text { C134 } \\
\text { Yes }\end{array}$ & None & None & None & $\begin{array}{l}\text { C132 } \\
\text { Yes }\end{array}$ & None \\
\hline \multicolumn{7}{|c|}{ ADP Setup Parameters } \\
\hline Avg Interval (s) & 900 & & & & 900 & \\
\hline Profile Interval (s) & 1800 & & & & 1800 & \\
\hline \multicolumn{7}{|c|}{ Wave Sampling Parameters } \\
\hline $\begin{array}{l}\text { Record Pseries } \\
\text { Interval (min) }\end{array}$ & 60 & & & & 60 & \\
\hline PseriesRate $(\mathrm{Hz})$ & 2 & & & & 2 & \\
\hline $\begin{array}{l}\text { PseriesLength } \\
\text { (points) }\end{array}$ & 4096 & & & & 4096 & \\
\hline PseriesDuration (s) & 2048 & & & & 2048 & \\
\hline $\begin{array}{l}\text { ADVOcean Serial } \\
\text { No. }\end{array}$ & B45 & B46 & B51 & None & B52 & B59 \\
\hline Paros. Serial No. & 66890 & 69128 & 69130 & & 69180 & 69181 \\
\hline OBS Serial No. & 0795 & 0928 & 1242 & & 1243 & 1244 \\
\hline $\begin{array}{l}\text { Distance: deck to } \\
\text { ADV }(\mathrm{cm})\end{array}$ & 97.8 & 101.1 & 97.8 & & 97.8 & 98.4 \\
\hline $\begin{array}{l}\text { Distance: deck to } \\
\text { OBS }(\mathrm{cm})\end{array}$ & 79.1 & 81.3 & 78.1 & & 78.1 & 80.6 \\
\hline \multicolumn{7}{|l|}{ ADVO Parameters } \\
\hline SampRate $(\mathrm{Hz})$ & 2.00 & 2.00 & 2.00 & & 2.00 & 2.00 \\
\hline Burst Interval (s) & 7200 & 7200 & 7200 & & 7200 & 7200 \\
\hline Samples Per Burst & 4096 & 4096 & 4096 & & 4096 & 4096 \\
\hline Burst Length (s) & 2048 & 2048 & 2048 & & 2048 & 2048 \\
\hline Seabird Serial No. & None & None & None & 131 & None & None \\
\hline $\begin{array}{l}\text { Tide Measurement } \\
\text { Int. (min) }\end{array}$ & & & & 20 & & \\
\hline $\begin{array}{l}\text { Wave Measure- } \\
\text { ment Int. (hr) }\end{array}$ & & & & 2 & & \\
\hline $\begin{array}{l}\text { No of wave sam- } \\
\text { ples/burst }\end{array}$ & & & & 1200 & & \\
\hline $\begin{array}{l}\text { Burst sample rate } \\
(\mathrm{Hz})\end{array}$ & & & & 2 & & \\
\hline Tide Samples/day & & & & 72 & & \\
\hline Wave Bursts/Day & & & & 12 & & \\
\hline
\end{tabular}




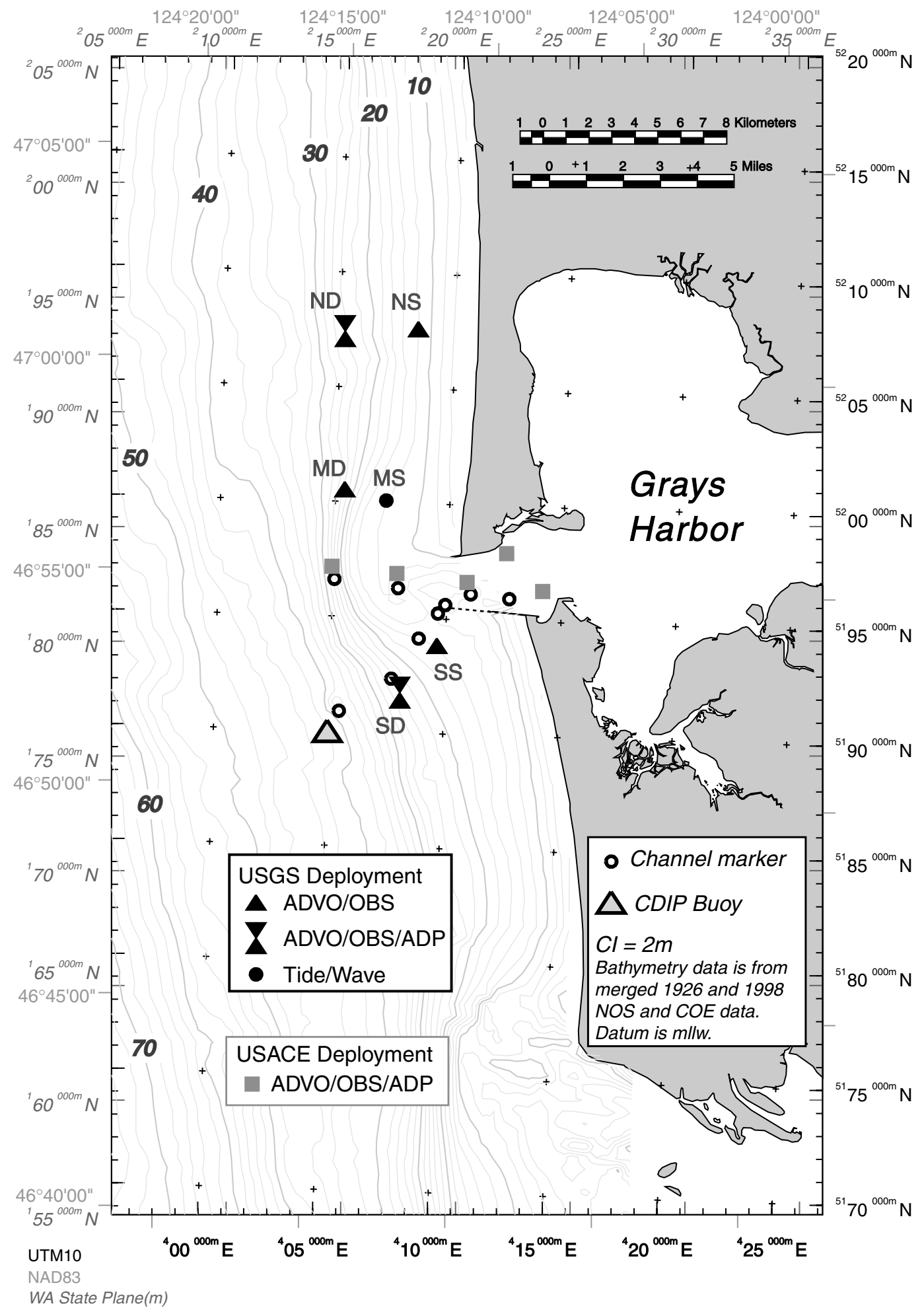

Figure 1. Map showing locations of the instrumented tripods for the wave experiment. 


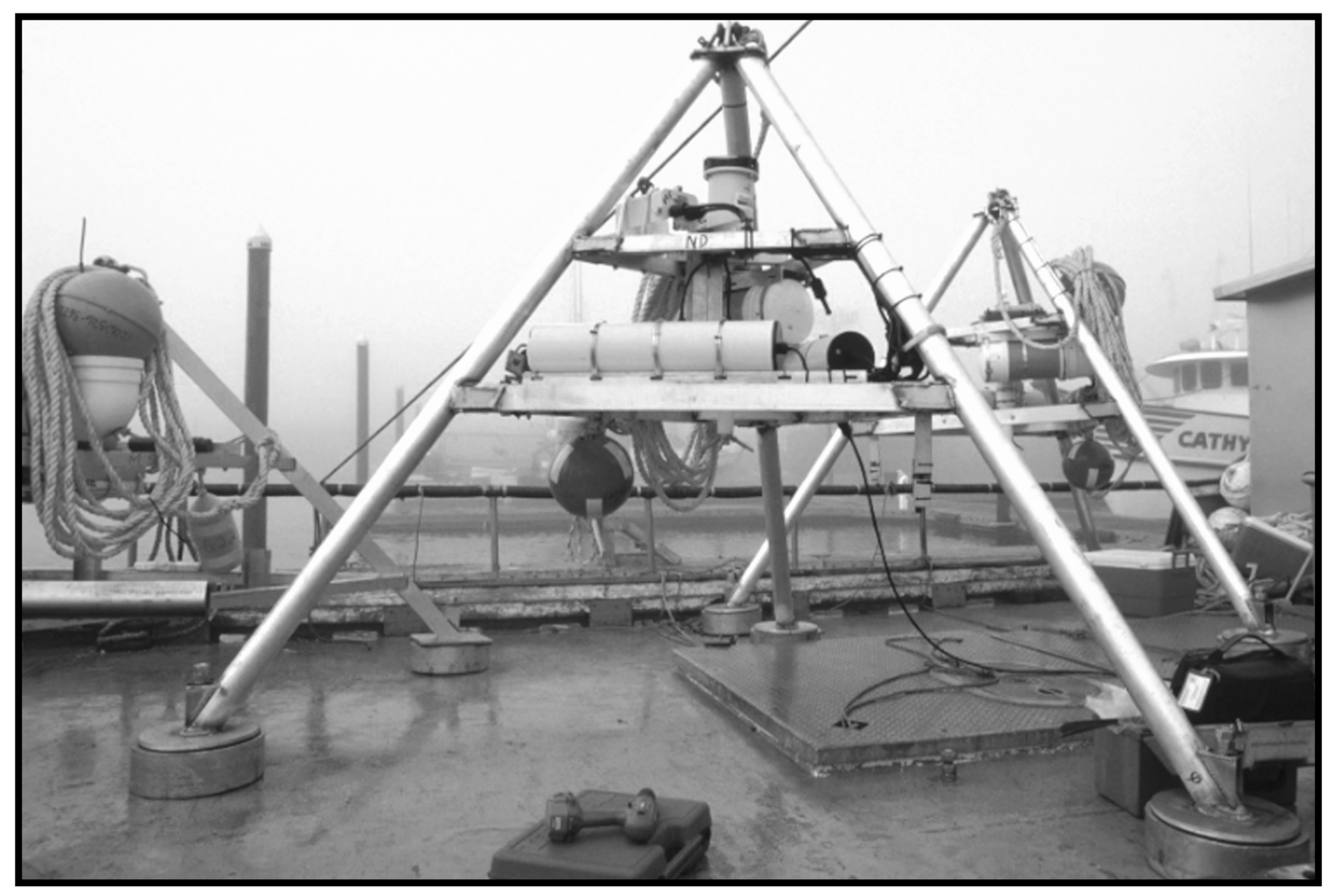

Figure 2. Photograph showing the instrumented tripods deployed (from left to right) at Sites MS, ND, and NS. 

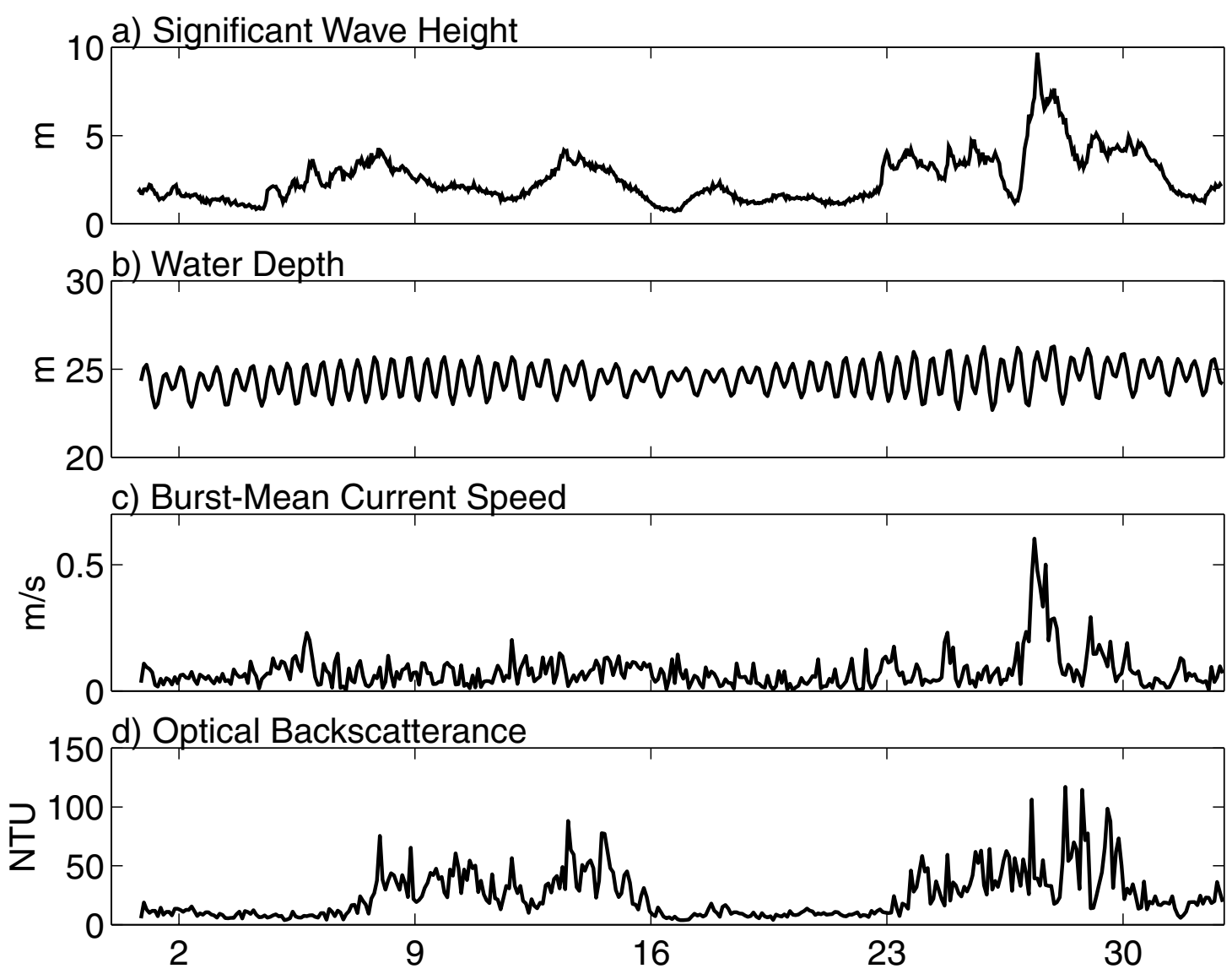

October, 1999

Figure 3. Time series of mean values of significant wave height, water depth, current speed near the bed, and suspended-sediment concentration from Site ND. 


\title{
DATA COLLECTION FOR ESTABLISHING NUMERICAL MODELS OF GRAYS HARBOR, WASHINGTON
}

\author{
Mary A. Cialone, U.S. Army Engineer Research and Development Center, Coastal \\ and Hydraulics Laboratory \\ Nicholas C. Kraus, U.S. Army Engineer Research and Development Center, Coastal \\ and Hydraulics Laboratory \\ Eric Nelson, U.S. Army Engineer District \\ Alex Sumeri, U.S. Army Engineer District \\ Robert Parry, U.S. Army Engineer District \\ David B. Hericks, Pacific International Engineering \\ William G. Grosskopf, Offshore \& Coastal Technologies, Inc.-East Coast \\ Keith Kurrus, Evans-Hamilton Inc.
}

\section{INTRODUCTION}

Numerical models of the waves, currents, and sediment transport are being established for the entrance and bay at Grays Harbor, Washington. The models will be ground-truthed with measurements made of the waves, wind, water level, currents, and suspended sediment, supplemented by dredging records. Information gained through this investigation will assist the U.S. Army Corps of Engineers (USACE), Seattle District in the design and maintenance of the Grays Harbor Federal navigation project, including:

1) development of strategies to better manage the diminishing supply of maintenance dredged material that is suitable for placement on or near eroding beaches. For example, minimizing the potential for breaching in the vicinity of the south jetty is desirable for maintaining integrity of the structure.

2) examination of alternatives for realignment of the navigation channel to reduce maintenance dredging, with particular interest on the Point Chehalis Reach and the Cow Point Reach.

This presentation will describe field measurements being made as part of this study.

\section{FIELD-DATA COLLECTION}

The full data-collection program consists of:

1) bathymetry measurements by survey boat in the offshore and along maintained and natural channels;

2) a Light Detection and Ranging (LIDAR) survey and aerial photography of land and tidal flats performed during lower tide in the bay (approximately $150 \mathrm{~km}^{2}$ ); 
3) water level at five locations around the periphery of the bay, and wind and barometric pressure on a tower near the U.S. Coast Guard Station, Grays Harbor; and

4) waves, water level, tidal currents, and suspended sediment at seven bottom-residing tripods.

The tripod (Item 4) deployment interval of 11-13 September 1999 to mid-November spans two lunar months, with one intermediate servicing that was performed 11-14 October 1999. The tripods were deployed along or near the Federal navigation channel at Grays Harbor (Figure 1). Stations 1 through 6 extend from the entrance, through the inlet, and into the bay, with each tripod configured with a SonTek Hydra functioning as a directional wave gauge and an up-looking Acoustic-Doppler Profiler (1,500 kHz SonTek ADP) (Figure 2). The Hydras contain a down-looking Acoustic-Doppler Velocimeter (ADV) Ocean probe, a high-resolution Paroscientific or Druck Resonant Pressure Transducer (RPT) pressure sensor, and two optical backscatterence sensors (Downing Instruments OBS-3). The ADPs also contain a Druck RPT or a Paroscientific pressure sensor. The Hydras sample at $2 \mathrm{~Hz}$ for $34 \mathrm{~min}$, with a sampling interval of two hours and the ADPs record a 3-min average 10 times per hour, with a sampling interval of two hours. This instrument suite documents the waves, currents near the bottom, and water level; the current through the water column in $0.5-\mathrm{m}$ bins, and the suspended-sediment concentration.

Three tidal cycles of the velocity profile recorded by the ADP at Station 1 are shown in Figure 3. A maximum current speed of approximately $1.7 \mathrm{~m} / \mathrm{sec}$ was recorded for the upper portion of the water column. The single-depth speed time-series (bottom of Figure 3) is for the location $14 \mathrm{~m}$ above the tripod, as indicated by the marker on the right side of the contour plot. Combined with the velocity measured near the bottom by the ADV, the OBS yield sediment flux for observing the movement of dredged material and existing material that is re-suspended and transported. The purpose of the six stations is to capture surface-wave propagation through the inlet. Measurements are capturing diffraction into the bay, as well as the tidal flow and change of water level by tide and wind, that can contribute to sediment movement along the navigation channel and at particular areas such as Whitcomb Flats, an oyster-grounds leasing area.

Station 0 (the seaward-most location) was configured with a Hydra (ADV plus Paroscientific pressure sensor and two OBS-3 sensors) and an RDI Sentinel ADCP with directional wave-spectra firmware. The directional wave spectra from the RDI and Hydra data will be analyzed to determine if comparable data are derived from the two different measurement methods.

Five water-level gauges (Item 3) were placed around the periphery of the bay, including up the Chehalis River near Montesano, for calibration of the tidal circulation model. The water-level gauge installed at the Coast Guard station and weather station to be installed at the Coast Guard station will be equipped with voice reporting and two land-line phone numbers (one for the Corps and Port, and the other for the public) and provide the present 
water (tide) level, wind velocity, barometric pressure, and air temperature (typically, within past $15 \mathrm{~min}$ ). This gauge is expected to be operated for one year.

\section{NUMERICAL MODELS}

The field-data collection supports both wave and circulation numerical models for Grays Harbor. The ADCIRC long-wave hydrodynamic model can define the circulation and water level associated with both tide and wind. A two-dimensional (depth-averaged) version of ADCIRC is being applied. The Coastal Inlets Research Program (CIRP) has enhanced ADCIRC to include flooding and drying, and it has exercised the model in shallow water estuarine conditions such as at Willapa Bay, Washington. The CIRP has already implemented a reconnaissance-level version of ADCIRC at Grays Harbor. The model of Grays Harbor will be enhanced with field data collected in this investigation.

The spectral wave model STWAVE has been modified in the CIRP to represent the wavecurrent interaction including the wave-action equation, current-induced breaking, and wave blocking by a current (Smith et al. 1999). Communication between ADCIRC and STWAVE is necessary in this study for computing wave-generated currents through the transfer of the radiation stresses from STWAVE to ADCIRC and the transfer of tide-, wind-, and wave-generated currents from ADCIRC to STWAVE. In addition to improved wave modeling in the presence of a strong current, STWAVE will give more reliable estimates of sea-state in the channel. It can also quantify storm wave conditions as a function of the wind. The CIRP is presently upgrading STWAVE to include diffraction, as through the gap of the two jetties at Grays Harbor that opens to the bay, and this version will be used in this investigation.

The wave and hydrodynamic model outputs will drive a model of non-cohesive sediment transport based on the local water depth, currents, waves, and sediment grains through computation of local bed shear stresses. The spatial and temporal distributions of transport are then interpreted to identify areas of scour and deposition and quantify the rate of each.

\section{ACKNOWLEDGEMENTS}

Permission was granted by Headquarters, USACE to publish this information. The cooperation of instrument manufacturers named in this work is acknowledged, but no endorsement of equipment is implied.

\section{REFERENCES}

Luettich, R.A., Westerink, J.J., and Scheffner, N.W. 1992. ADCIRC: An Advanced Threedimensional Circulation Model for Shelves, Coasts, and Estuaries; Report 1, Theory and Methodology of ADCIRC-2DDI and ADCIRC-3DL, Technical Report DRP-92-6, U.S. Army Engineer Research and Development Center, Vicksburg, MS. 
Smith, J.M., Resio, D.T., and Zundel, A. K. 1999. STWAVE: Steady-State Spectral Wave Model, Report 1, User's Manual for STWAVE Version 2.0, Instruction Report CHL-99-1, U.S. Army Engineer Research and Development Center, Vicksburg, MS.

\section{Grays Harbor, Washington}

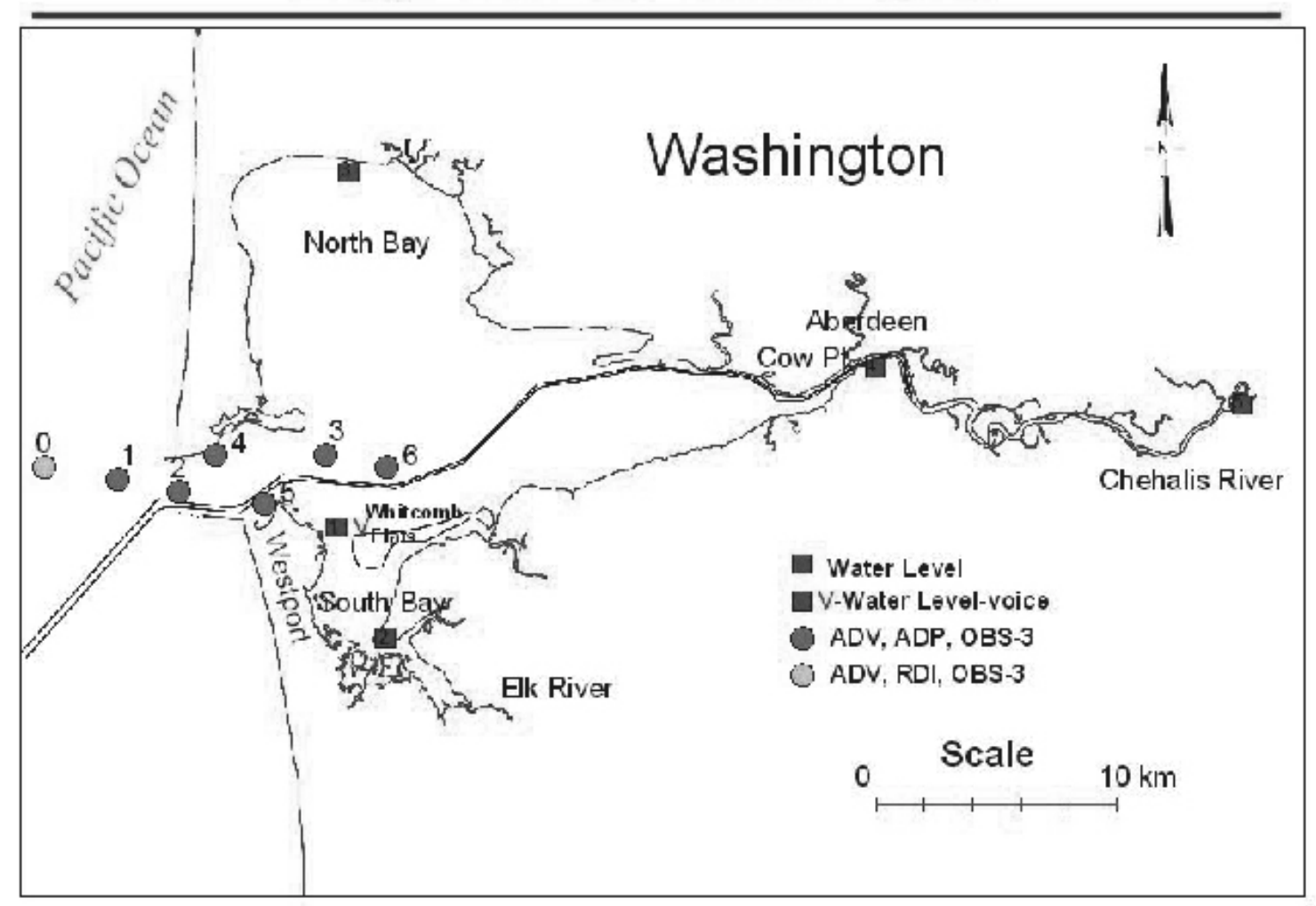

Figure 1. Gauge tripod locations, first deployment. 


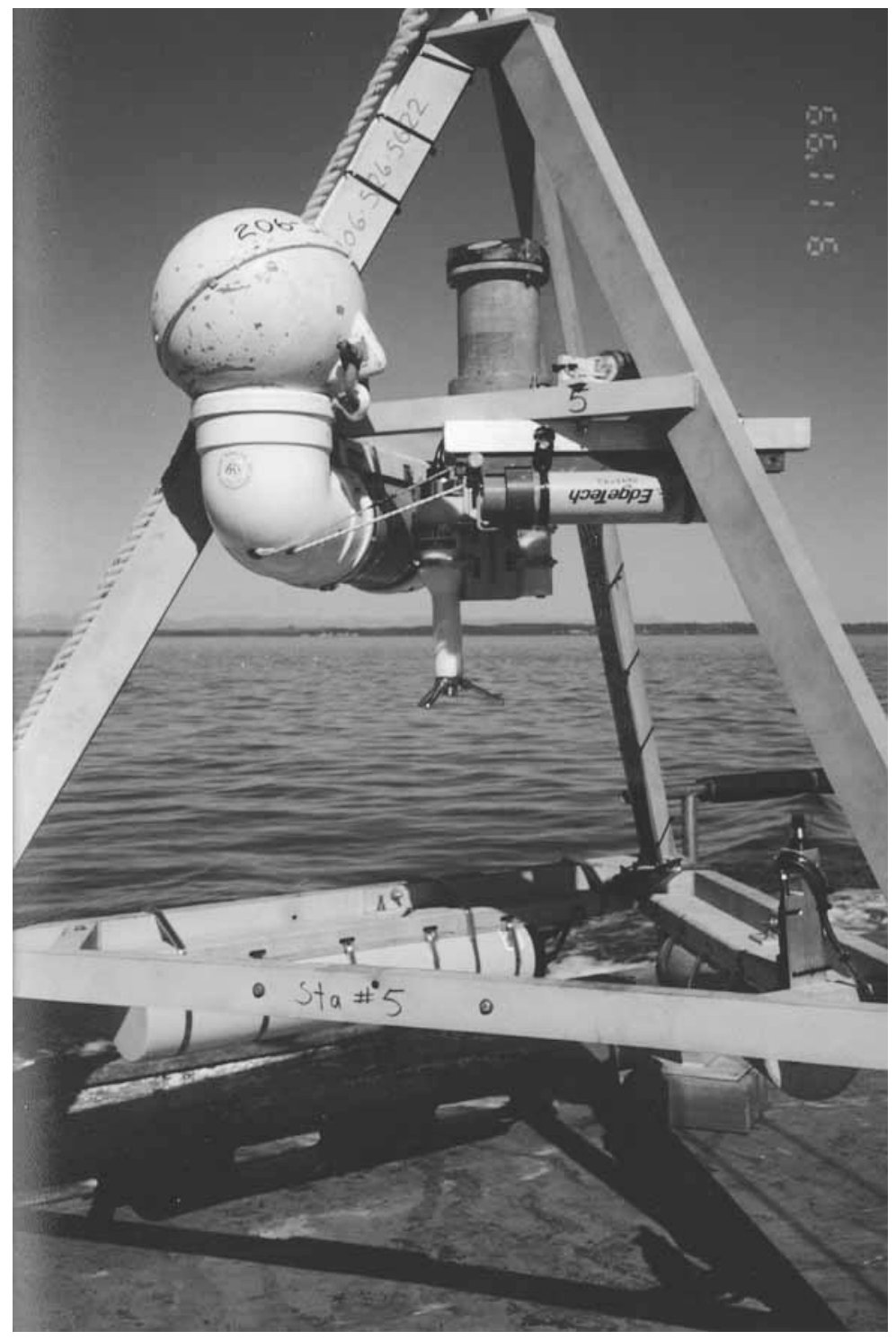

Figure 2. Tripod mounted with ADP, ADV, and OBS. 


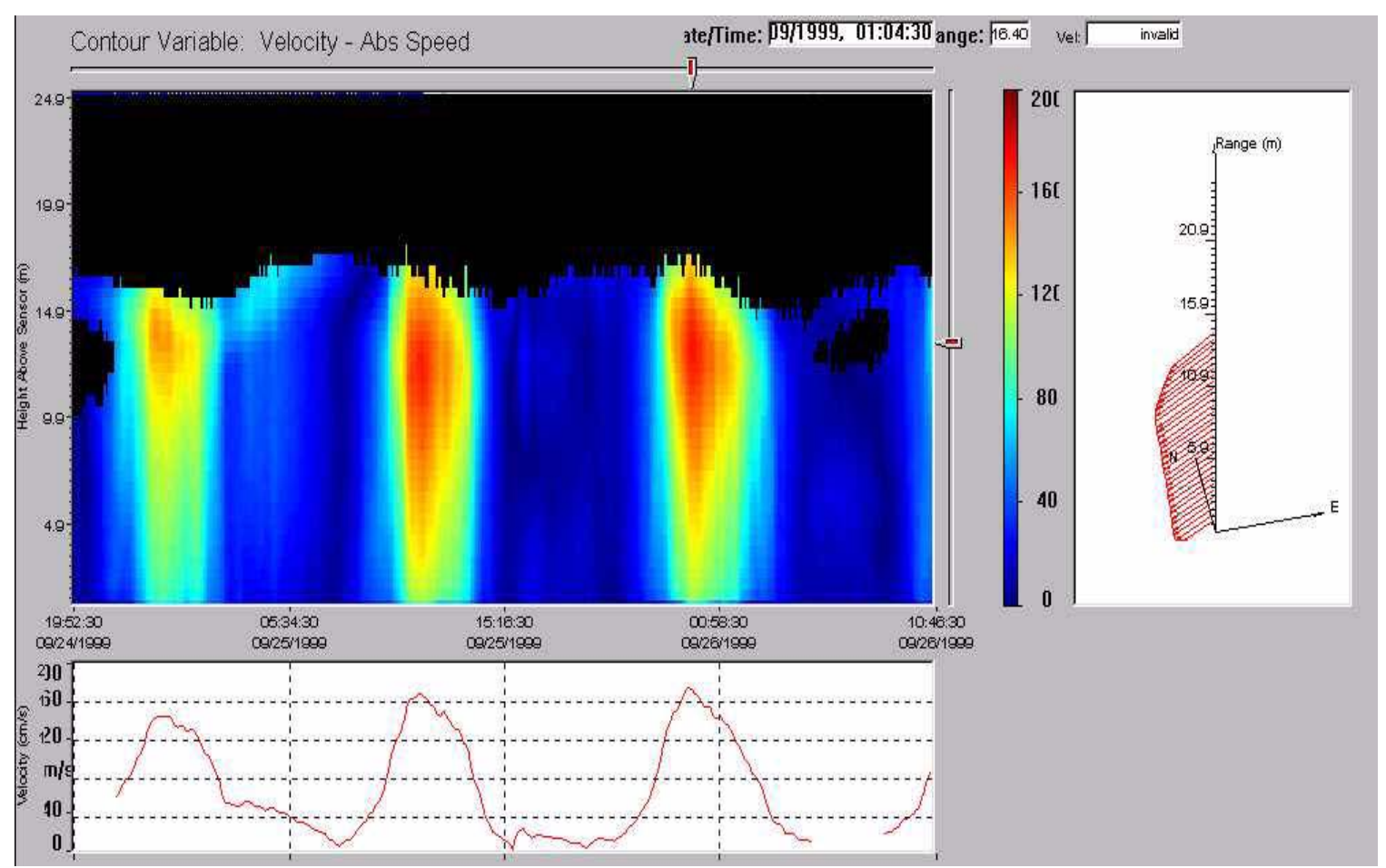

Figure 3. Velocity contour plot from ADP at Station 1. 


\section{U.S. ARMY CORPS OF ENGINEERS ACTIVITIES AT THE MOUTH OF THE COLUMBIA RIVER 1998-2000}

Rod Moritz, U.S. Army Corps of Engineers

\section{DREDGED MATERIAL MANAGEMENT AT MCR}

In 1997, the Portland District USACE, in concurrence with EPA, temporarily expanded ocean dredged material disposal site (ODMDS) E. This action was intended to provide the minimum additional capacity required for dredged material disposal at MCR (4.5 mcy), until a permanent ODMDS could be designated. It was anticipated that the 1997 expansion of ODMDS E would provide sufficient capacity for dredged material disposal (2 - $3.5 \mathrm{mcy}$ ), while enhancing the introduction of placed dredged material into littoral environment at MCR. ODMSD E is located within an erosive area of Peacock Spit in water depth 50-65 ft. An additional temporary dredged material disposal site, located along the south side of the MCR north jetty at water depth 45-65 ft, has been cleared for use (North Jetty site) and was first used in 1998 for the purpose of protecting the north jetty from foundation erosion. Since 1997, more than 7 mcy has been placed within ODMDS E and the North Jetty site. Periodic bathymetry surveys have been obtained at ODMDS E and the North Jetty site, for purposes of monitoring the accumulation and fate of placed dredged material. Based on recent wave/current measurements and bathymetric surveys, it is believed that most (if not all) of the dredged material placed at ODMDS $\mathrm{E}$ is being dispersed north-northwestward onto Peacock spit and, ultimately, introduced into the littoral environment of Washington.

\section{OCEANOGRAPHIC DATA COLLECTION AT MCR}

A multi-year effort to monitor the oceanographic environment at MCR was concluded in summer of 1999. The collaborative effort between Portland District, WES, OSU, and EPA acquired oceanographic data throughout the water column at each of three or four locations (depending on deployment period), with a suite of six instruments in flow regimes spanning from estuarine-dominated to ocean-dominated. Oceanographic data was concurrently measured at sites having different depths and exposure to waves and the MCR plume, to identify various degrees of environmental forcing and associated bottom sediment response. Data was acquired during 3 separate deployments spanning all oceanographic seasons, including onset of the 1997 El Niño. Deployment duration ranged from 6 weeks to 4 months. Sampling duration for instrumentation ranged from 10 to 17 minutes every 30 to 180 minutes, and sampling rates varied from 0.1 to $4 \mathrm{~Hz}$. In this regard, laboratory-quality data have been acquired in a highly energetic prototype setting. This data will be used by USACE to improve ODMDS life-cycle management at MCR. It is anticipated that SWCES investigators and the coastal engineering community will use this data to assess and improve methods for evaluating wave-current-seabed interactions. 


\section{Support for the Southwest Washington Coastal Erosion Study}

During 1999, Portland District has assisted the USGS-Menlo Park with several items related to the Study. In August-September, an offshore survey was obtained along 5 miles of the Long Beach Peninsula, between 30 - $200 \mathrm{ft}$ water depth. Combined with surveys obtained in 1998, the total coverage of Portland District bathymetric surveys is 6 miles south of MCR to within 6 miles south of Willapa Bay. Several assessments have been conducted to assess potential effects of Columbia River dams upon the sedimentary environment of the Lower Columbia River. On behalf of the USGS-Menlo Park, the Portland District procured on a fast-track schedule five Hydra cable assemblies for use in the Fall 1999 Southwest Washington Coastal Erosion Study field data collection effort. 


\title{
COLUMBIA RIVER MOUTH DREDGED MATERIAL DISPOSAL - COASTAL COMMUNITIES PLANS
}

\author{
Vladimir Shepsis, Pacific International Engineering
}

\begin{abstract}
To provide safe and reliable commercial navigation through the mouth of the Columbia River, the Portland District of the U.S. Army Corps of Engineers has, for many years, conducted regular maintenance dredging of the outer bar (and other reaches), routinely disposing of volumes of 2 to 5 million cubic yards of sediment per year. The dredged sediment has been placed at open water disposal sites located offshore from the river's mouth at various depths- typically from 70 to $300 \mathrm{ft}$. It is a concern that these disposal sites are outside of littoral drift boundaries and disposed sediment cannot be returned naturally to coastal shorelines.
\end{abstract}

The Washington Department of Ecology (WDOE) and United States Geological Survey (USGS) study (Ruggiero et al., 1999) has indicated that the rate of delivery of sediments from the Columbia River has diminished over the past century (Kaminsky et al., 1999). The amount of material being delivered into the littoral system and therefore available to build and sustain Washington State beaches has been significantly reduced, a situation that seems to have been aggravated by management of the river's flow and sedimentation.

In consideration of the fundamental role of the Columbia River sediment for sustaining Washington's ocean shorelines, the associated Coastal Communities of southwest Washington have authorized an expedited engineering assessment of the beneficial use of dredged sediment at the mouth of the Columbia River in order to develop a strategy to restore the supply of sediment to our beaches, while maintaining safe navigation and other ocean resources. This study has been conducted by Pacific International Engineering, PLLC (PI Engineering), an engineering firm based in Edmonds, Washington.

PI Engineering developed and presented to the Corps of Engineers a conceptual proposal for the beneficial use of the mouth of the Columbia River (MCR) dredged material. This proposal recommends placement of the MCR dredged material at Benson Beach using a sump at a re-handling site located on the south side of the North Jetty (Figure 1). The preliminary analysis shows that the location of the sump will be protected from wave impact during re-dredging-disposal operations. Usually, dredging at the MCR occurs during the June-September months. Columbia River wave buoy data (Table 1) shows that most of the waves ( 89 percent) during these months are from $\mathrm{N}-\mathrm{W}$ directions. Waves from this direction are most likely sheltered by the North Jetty.

The Demonstration Project is assumed to be a cooperative effort between the Coastal Communities (PI Engineering), the Southwest Washington Coastal Erosion Study (WDOE and USGS) and the Portland District Corps of Engineers. Under this cooperative effort, the WDOE will provide PI Engineering with a complete listing of sources of information 
on the following topics as a first milestone of the study. The WDOE will summarize available information on each of the following topics in separate reports:

1) Columbia River sediment characteristics at the mouth and on the bar. Characteristics include detailed sediment size distribution and mineralogy;

2) historical and current sediment budget at the MCR. Historical in this sense is prior to the navigation project, but not earlier than 150 years ago;

3) patterns of sediment migration at the MCR, distinguished by season;

4) potential areas of erosion during the next 25 to 50 years along the Washington and Oregon Coasts; and

5) historical and current dredging and dredged material disposal practices, chronologically specifying volumes and locations of disposal and a history of authorized depth of the bar channel.

Understanding that various technical, environmental, and economical questions must be answered prior to any changes in the dredged material disposal practice at the MCR, PI Engineering has proposed the Demonstration Project with an intensive monitoring program. The monitoring program will address the following issues:

- safe re-handling of dredged material;

- North Jetty stability;

- navigation channel sedimentation;

- Benson Beach capacity;

- adjacent areas crab/fish habitat impacts; and

- existing Site E bottom depth criteria to provide safe navigation for small crafts.

The detailed scope of the monitoring program will be prepared in coordination with the Corps of Engineers, WDOE, and other interested state agencies. The Demonstration Project is preliminary scheduled to be conducted during 2000-2001. Actual dates of dredging and placement of dredged sediment at Benson Beach will be dependent on complete and reliable required technical information, permitting procedures, and funding appropriation.

\section{REFERENCES}

Ruggiero, P., Côté, J., Kaminsky, G., and Gelfenbaum, G. 1999. Scales of variability along the Columbia River littoral cell, Proceedings of the 4th International Symposium 
on Coastal Engineering and Science of Coastal Sediment Processes, 2, pp. 1692-1707.

Kaminsky, G., Buijsman, M., Gelfenbaum, G., Ruggiero, P., Jol, H., Gibbs, A., and Peterson, C. 1999. Synthesizing geological observations and processes response data for modeling coastal change at management scale, Proceedings of the 4th International Symposium on Coastal Engineering and Science of Coastal Sediment Processes, 2, pp. 1708-1723.

Table 1. Wave height occurrence vs. wave direction during June-September period (3 years 1995-1998 data).

\begin{tabular}{lll}
\hline $\begin{array}{l}\text { Significant Wave } \\
\text { Height (ft) }\end{array}$ & Direction: North through West & Direction: South through West \\
\hline $0-2$ & $0.1 \%$ & $0.0 \%$ \\
$2-4$ & $29.0 \%$ & $6.1 \%$ \\
$4-6$ & $38.7 \%$ & $1.9 \%$ \\
$6-8$ & $14.5 \%$ & $1.1 \%$ \\
$8-10$ & $4.9 \%$ & $0.5 \%$ \\
$>10$ & $2.8 \%$ & $0.4 \%$ \\
Total & $89.9 \%$ & $10.1 \%$ \\
\hline
\end{tabular}




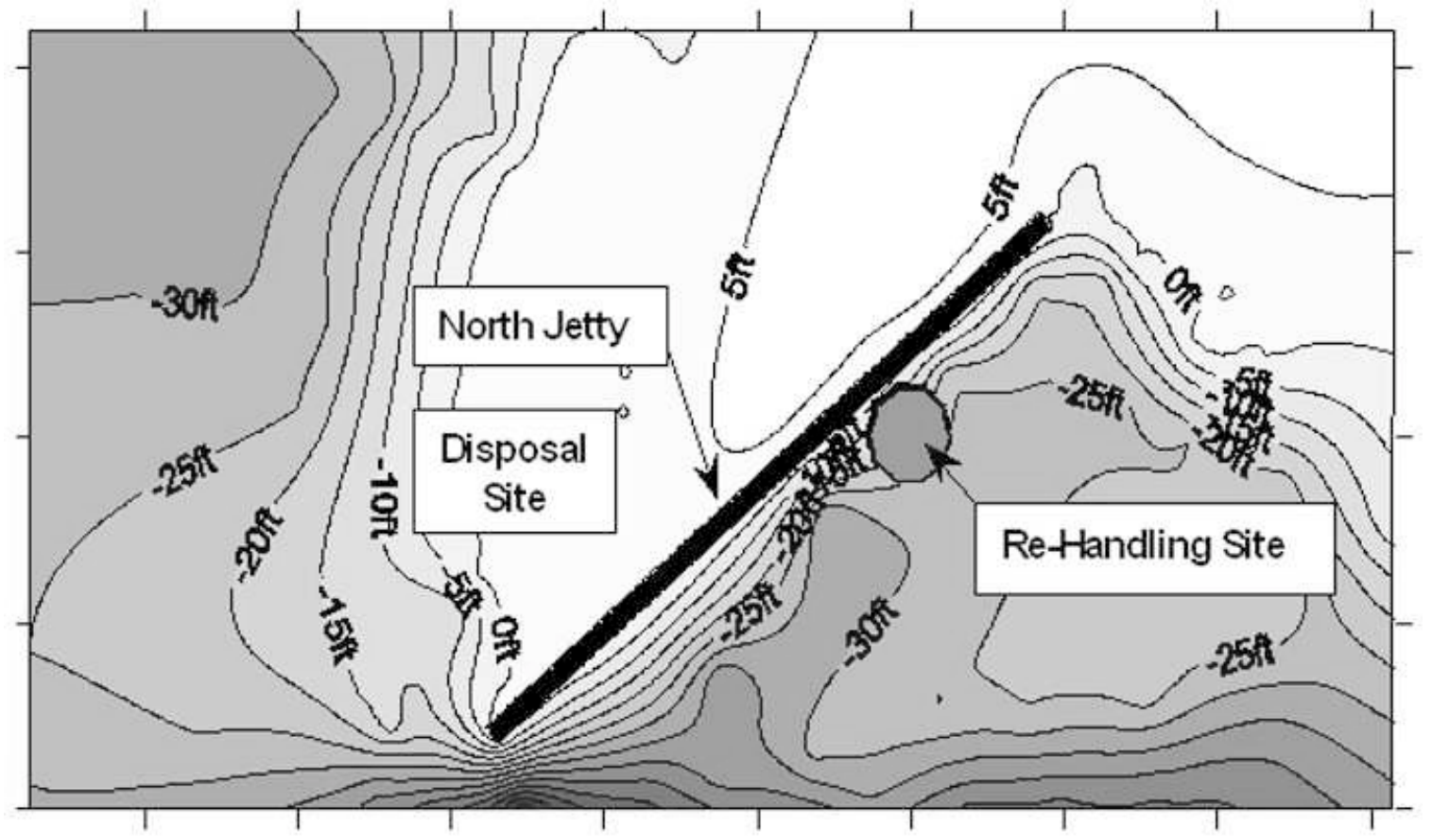

Figure 1. Proposed rehandling and disposal sites. 


\section{SCALES OF MORPHOLOGIC VARIABILITY FROM EVENT RESPONSE TO INTERANNUAL CHANGE}

Peter Ruggiero, Washington Department of Ecology

George Kaminsky, Washington Department of Ecology

\section{INTRODUCTION}

The dynamic interaction between environmental forcing and coastal morphology occurs over at least five orders of magnitude in both time and space. Temporal response ranges from multiple wave cycles (tens of seconds) to interannual climatic variations (El Niño) and spatial variability ranges from ripples to large-scale coastal behaviour. In order to aggregate to scales relevant for coastal management a difficult sampling problem must be overcome. This paper presents results from a nested sampling scheme for the Columbia River littoral cell (CRLC) that is designed to resolve spatial scales ranging from hundreds of meters to tens of kilometers and temporal scales ranging from storm events to years. A combination of GPS technologies and remote sensing techniques have been employed to acquire baseline data of the coastal zone from approximately $+10 \mathrm{~m}$ to $-10 \mathrm{~m}$ elevation (MSL) along this highly dynamic coast. The magnitudes of morphologic change associated with a variety of time and space scales are presented with examples from the different components of the Southwest Washington Coastal Erosion Study's beach morphology monitoring program (Ruggiero et al., 1998; Ruggiero et al., 1999).

\section{EVENT RESPONSE}

Several major storm events have occurred since the inception of the monitoring program in 1997 and rapid response surveys have documented morphological response to these events. For example, during the months of January and February 1998, data from the Grays Harbor wave buoy indicated 13 events with waves that reached or exceeded $6.0 \mathrm{~m}$. Three of these events occurred between 21 January and 3 February 1998. Beach profile surveys were conducted at Ocean Shores, WA, the southern limit of the North Beach subcell, both before and after these events. These large wave heights were coupled with water levels $0.5 \mathrm{~m}$ above their predicted elevations associated with a major El Niño (Kaminsky et al., 1998). During this period, the beach was locally lowered as much as $2.0 \mathrm{~m}$ while dune erosion of over $10 \mathrm{~m}$ was measured. Figure 1 shows beach profile change of approximately $110 \mathrm{~m}^{3} \mathrm{~m}^{-1}$. In contrast is the morphologic response to the largest storm ever recorded by the Grays Harbor buoy that occurred on 3 March 1999. Deep-water wave heights exceeded $9.0 \mathrm{~m}$ for over 5 hours, peaking at $10.6 \mathrm{~m}$ and was accompanied by a storm surge of $1.4 \mathrm{~m}$ forced by sustained $80 \mathrm{~km} / \mathrm{hr}$ winds. Coastal flooding was widespread throughout the Columbia River littoral cell (CRLC), particularly in Ocean Shores where several houses were damaged and a public rest room was destroyed. However, the sub-aerial beach at Ocean Shores responded only by flattening between the 1.0 and $4.0 \mathrm{~m}$ contours. Mean beach surface change measured by the CLAMMER between 1 March 1999 and 3 March 1999 was only $0.02 \mathrm{~m}$ over a $2 \mathrm{~km}$ alongshore distance. 


\section{SEASONAL VARIABILITY}

A three-dimensional sub-aerial beach surface map has been collected at Ocean Shores, WA nominally on a monthly basis since August 1997 in order to document the seasonal variability of the southern end of the North Beach sub-cell. Results from the $4 \mathrm{~km}$-long surveys at Ocean Shores have been aggregated into bulk parameters that are presented in Figure 2. The top panel illustrates the mean beach surface elevation change over a 30 month period. Beach surface change is calculated from three-dimensional grids that have been generated from each of the data sets with the August 1997 survey serving as a baseline for subsequent comparison. A clear seasonal signal is evident in the data with up to $0.5 \mathrm{~m}$ of mean beach surface lowering during the winter of 1998. By October 1998 the beach had recovered slightly beyond its summer 1997 elevation and then began to lower again. The summer of 1999 witnessed net elevation gain over this stretch of coast of up to $30 \mathrm{~cm}$ by October. At the time of publication, January, 2000, the beach surface is approximately $35 \mathrm{~cm}$ below its August, 1997 elevation.

This method of calculating beach surface elevation change, from subsequent surface grids, becomes problematic when surveys do not extend the same distance offshore, due to tide or wave conditions at the time of the survey, or when a shoreline has a long term trend of either recession or progradation. Therefore, a more robust parameter used to quantify beach change is contour line migration. The second panel in Figure 2 also reveals the seasonal cycle at Ocean Shores through the patterns evident in the behaviour of the 1.0, 2.0 and $3.0 \mathrm{~m}$ contour lines (NAVD 88). Each of these lines represents the average (over 4 $\mathrm{km})$ change of the respective contour line as measured from the August 1997 baseline. Variability of contour position (a good proxy for shoreline change, Daniels et al., this volume) is on the order of $40 \mathrm{~m}$ (from $-25 \mathrm{~m}$ to $+15 \mathrm{~m}$ ) at this beach during this period.

The data presented in panels 1 and 2 of Figure 2 represent bulk parameters averaged over the $4 \mathrm{~km}$ surface map. Panel 3 of Figure 2 separates out the horizontal change of the $2.0 \mathrm{~m}$ contour for 4 individual $1 \mathrm{~km}$ sections. It is immediately evident that there is also substantial alongshore variability that had been masked by the previous analysis. The kilometer closest to the North Jetty of Grays Harbor experiences the largest variability and also had the largest 2-year net accretion of the $2.0 \mathrm{~m}$ contour $(\mathrm{O}(30 \mathrm{~m})$ of accretion by October 1999). Also of interest in this panel is the temporal variability in the seasonal cycle of contour change. For example, following the September 1998 survey, the 2nd, 3rd, and 4th kilometer began to erode while the kilometer closest to the jetty continued to accrete until January 1999.

Three-dimensional surface maps have been collected biannually at 16 sites along the CRLC since summer 1997. Figure 3 presents the horizontal change of the $2.0 \mathrm{~m}$ contour line averaged over each 4-km long surface map using the summer 1997 as a baseline. The data reveal the expected seasonal variability in shoreline position with approximately 30 $40 \mathrm{~m}$ difference between the summer and winter location. 


\section{ANNUAL TO INTERANNUAL CHANGE}

Shoreline (contour line) change rates are featured in Figure 4, both for the 1-year period of 1997 - 1998 and the 2-year period of 1997 - 1999. After 2 years, 7 of the 16 surface map sites experienced net erosion as compared to 5 during the first year. Comparing decadalscale shoreline change rates with two years of monitoring data is probably imprudent due to the marked difference in time scales. However, in Figure 4 decadal-scale shoreline change rates for the entire littoral cell have been plotted (from 1974 to 1995). Remarkably, the majority of the 16 surface map sites show similar magnitudes and trends during 1997 - 1999 as during the 21-year period. The largest difference between rates occurs at North Cove and Fort Canby (erosion hot spots) and at the northern ends of the Clatsop Plains, Grayland Plains and North Beach sub-cells. Some of these differences can be explained by the anomalous northerly sediment transport that occurred during the El Niño year of 1997/1998.

\section{CONCLUSIONS}

The beach morphology monitoring program is revealing that the Columbia River littoral cell is an extremely dynamic coastal system with complex morphologic behaviour evident at a variety of time and space scales. For example, morphologic change due to single storm events has been shown to not linearly depend only on wave conditions, but rather on a combination of forcing and antecedent morphologic conditions. On the other hand, the $1997 / 1998$ El Niño event, which by some measures was the largest of the last century, forced morphologic change over scales of tens of kilometers. The nested sampling scheme employed by this study appears to have resolved the realignment of each of the sub-cells with the acute southerly wave directions associated with the El Niño (Kaminsky et al., 1998). As the program continues to mature more direct linkage between the morphology data and decadal-scale coastal change modeling will become possible.

For example, Figure 5 illustrates cross-shore profile change since summer 1997 at a site near the North Jetty of Grays Harbor. Shown along with the change of the $2.0 \mathrm{~m}$ and $3.0 \mathrm{~m}$ contour lines is the predicted shoreline at this location derived from the 1-line shoreline change model UNIBEST (Buijsman, this volume). This method of presenting beach profile data reveals both short-term morphologic variability as well as the level of skill with which the model predicts future shoreline position at a particular location. Again, two years is too short of a period to accurately quantify decadal scale modeling performance. However, this example suggests how monitoring data will be assimilated into the modeling component of the Study through the refinement of both conceptual and numerical models.

\section{ACKNOWLEDGMENTS}

The authors would like to thank all of the lovers of wet, cold, and sleepless winter days and nights who have contributed to the morphology monitoring program. 


\section{REFERENCES}

Buijsman, M.C. this volume. Shoreline change modeling - in relation to the sediment budget, Southwest Washington Coastal Erosion Workshop Report 1999, U.S. Geological Survey Open-File Report.

Daniels, R.C., Ruggiero, P., and McCandless, D. this volume. Interpretation of the average high water line from aerial photography: variability and repeatability, Southwest Washington Coastal Erosion Workshop Report 1999, U.S. Geological Survey Open-File Report.

Kaminsky, G., Ruggiero, P., and Gelfenbaum, G. 1998. Monitoring coastal change in southwest Washington and northwest Oregon during the 1997/98 El Niño, Shore and Beach, 66 (3), pp. 42-51.

Ruggiero, P., Côté, J., Kaminsky, G., Gelfenbaum, G. 1999. Scales of variability along the Columbia River littoral cell, Proceedings of Coastal Sediments '99, ASCE, pp. 1692-1707.

Ruggiero, P., Kaminsky, G. and Plant, N.G. 1998. Coastal morphologic variability of high energy dissipative beaches, Proceedings of the 26th International Conference on Coastal Engineering, ASCE, pp. 3238-3251. 


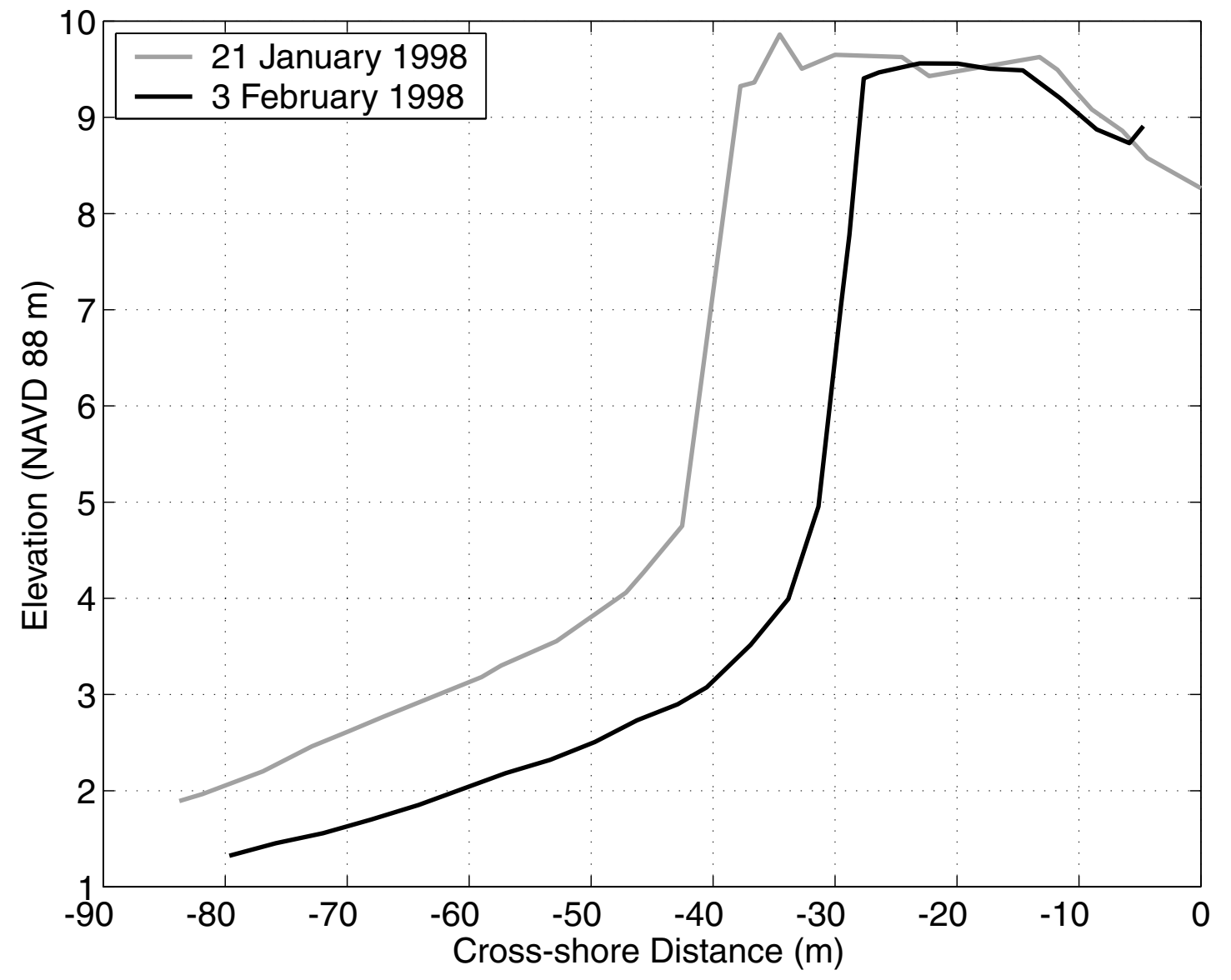

Figure 1. Beach profile change at Ocean Shores, WA between 21 January 1998 and 3 February 1998. Approximately $110 \mathrm{~m}^{3} \mathrm{~m}^{-1}$ of beach erosion occurred during this period. 

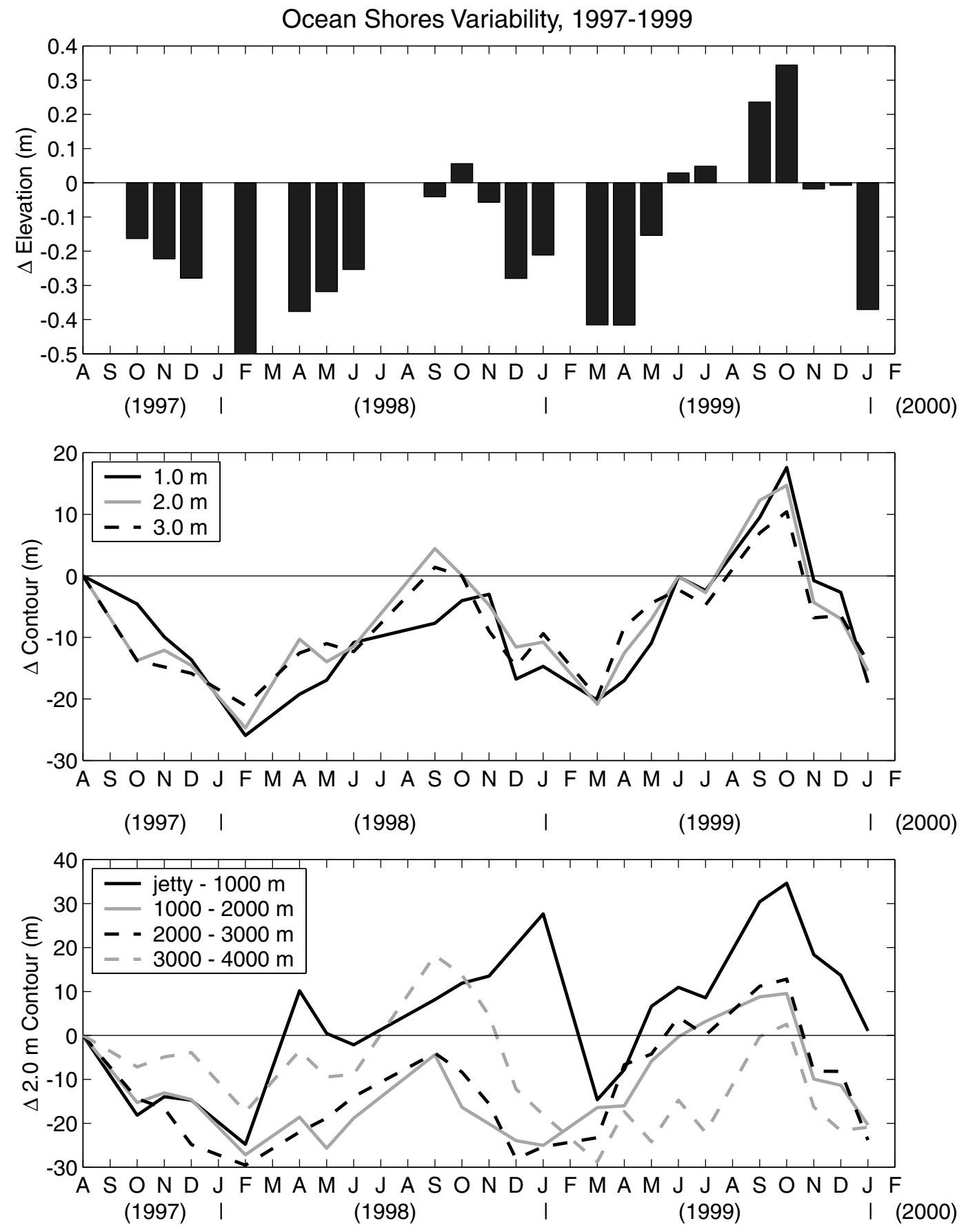

Figure 2. Monthly change at Ocean Shores, WA, represented as A) mean beach surface elevation change, B) mean change of the $1.0 \mathrm{~m}, 2.0 \mathrm{~m}$ and $3.0 \mathrm{~m}$ contour lines (NAVD 88) from an August 1997 baseline (values are averaged over a $4 \mathrm{~km}$ alongshore distance), and C) mean change of the $2.0 \mathrm{~m}$ contour line for each of four $1.0 \mathrm{~km}$ sub-sections of the $4.0 \mathrm{~km}$ surface map. 


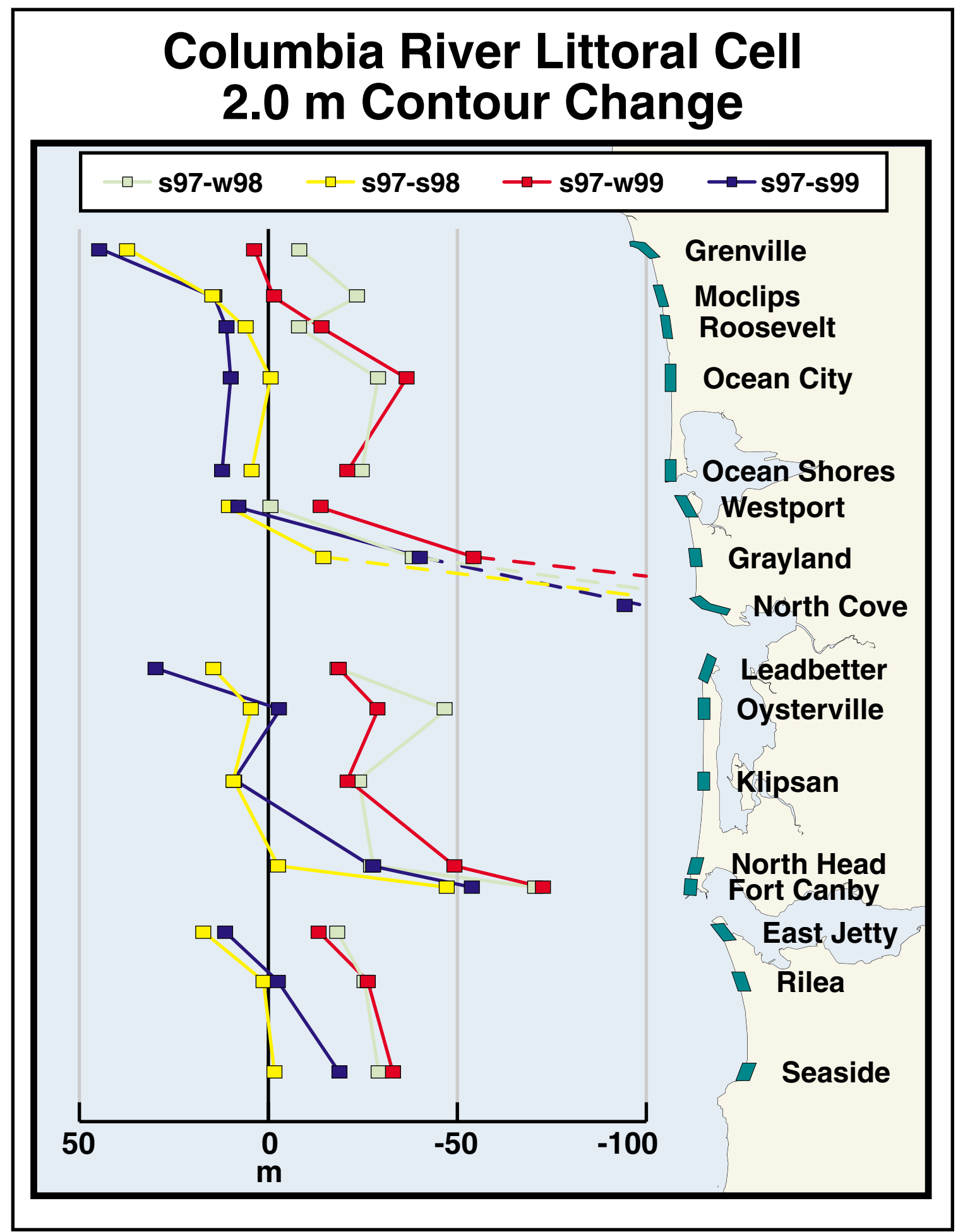

Figure 3. Seasonal - annual - interannual variability of the $2.0 \mathrm{~m}$ contour as averaged over each of the sixteen $4.0 \mathrm{~km}$ long surface maps. 


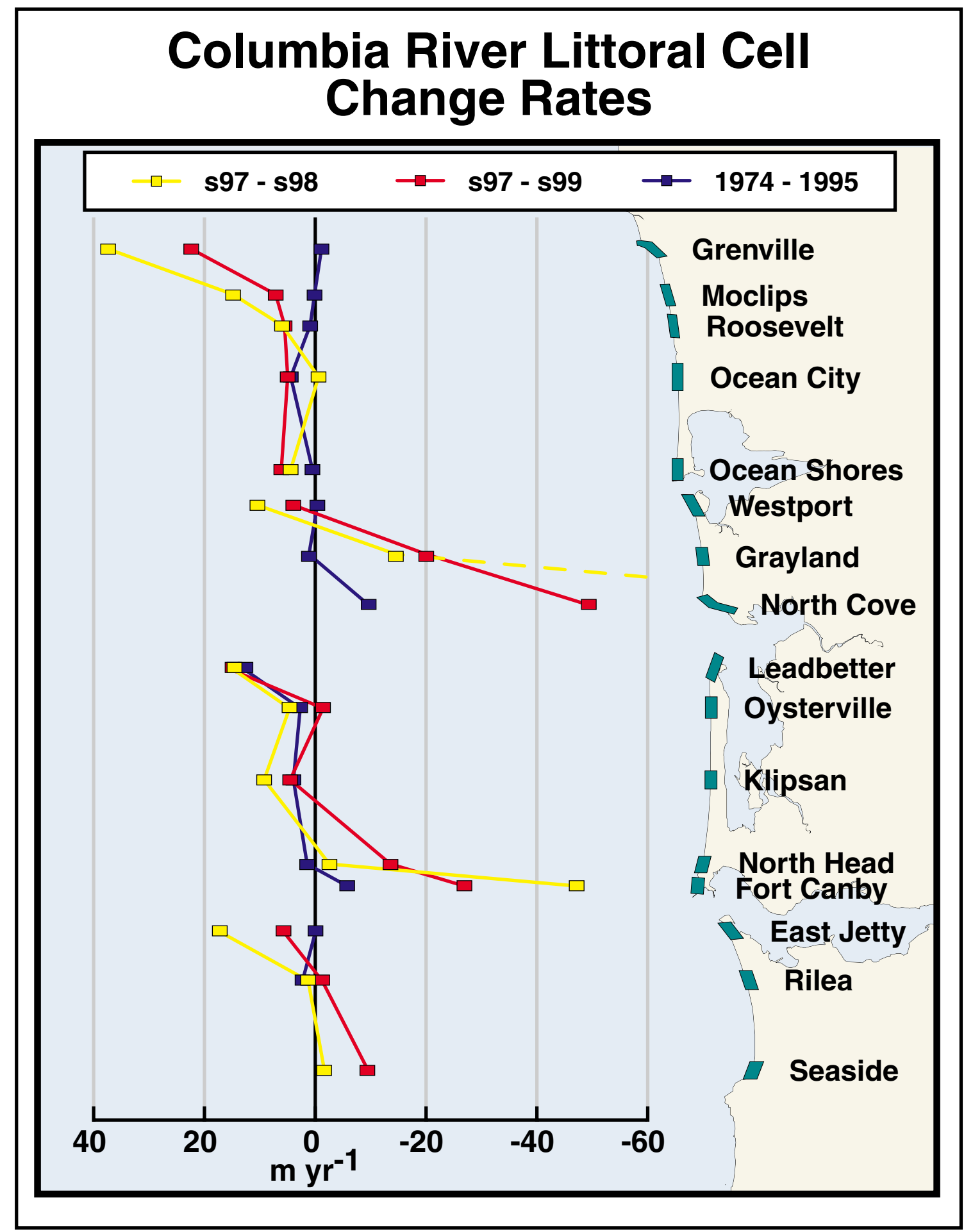

Figure 4. Change rates of the $2.0 \mathrm{~m}$ contour for 1-year (1997-1998) and 2-year (1997-1999) periods. Shoreline change rates derived from aerial photography for the period 1974-1995 are also on the figure. 

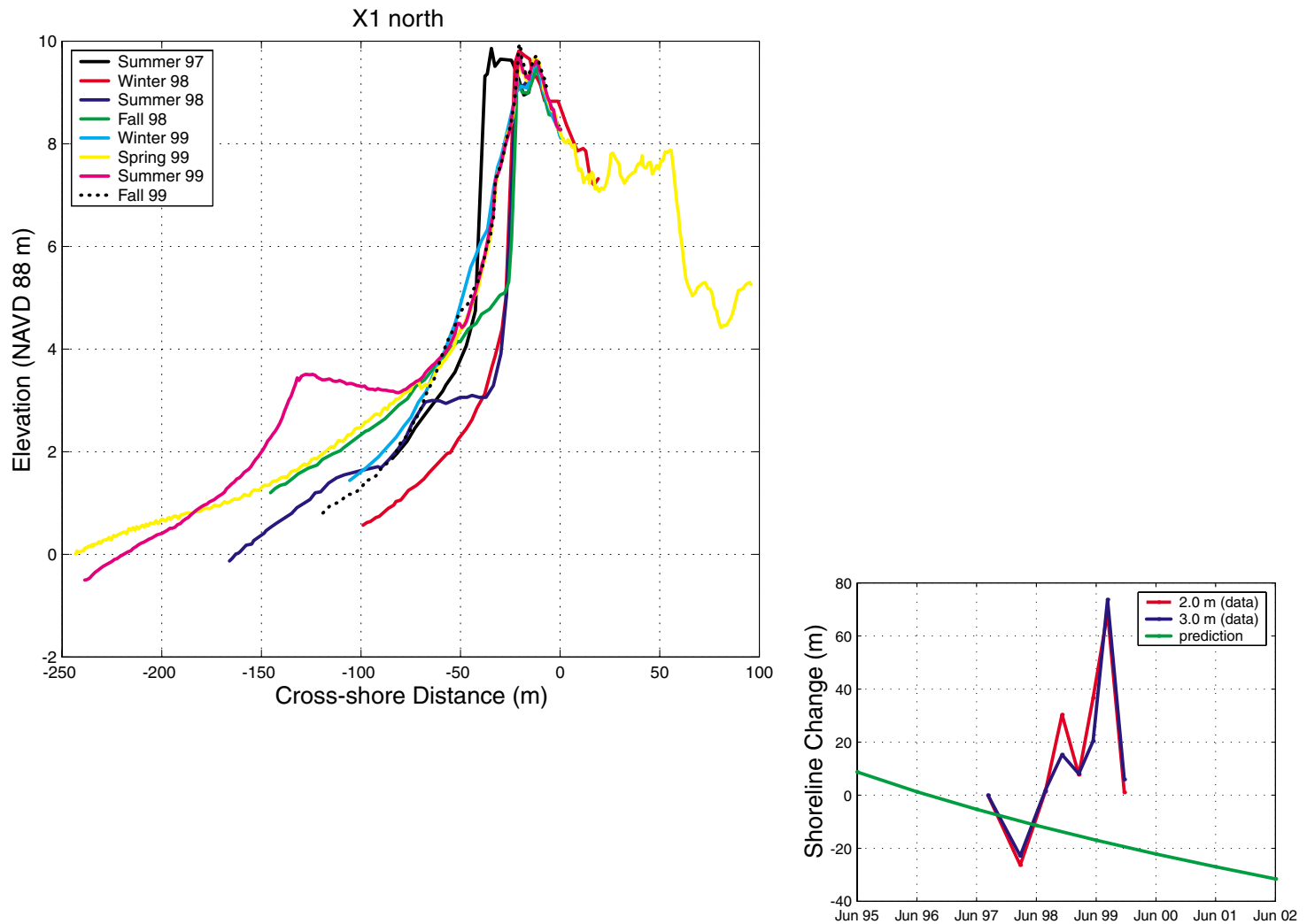

Figure 5. Beach profile data collected at site X1 North $(500 \mathrm{~m}$ north of the North Jetty of Grays Harbor). A time series of the location of the $2.0 \mathrm{~m}$ and the $3.0 \mathrm{~m}$ contour line as derived from the profile data is compared to model predictions of shoreline position between 1995 and 2002. 


\title{
COLUMBIA RIVER LITTORAL CELL SEDIMENT BUDGET: WHAT CAN WE SAY ABOUT THE SOURCE?
}

\author{
Guy Gelfenbaum, U. S. Geological Survey \\ Christopher Sherwood, U. S. Geological Survey \\ David Twichell, U. S. Geological Survey \\ Ann Gibbs, U. S. Geological Survey \\ Curt D. Peterson, Portland State University \\ Maarten Buijsman, Washington Department of Ecology \\ George Kaminsky, Washington Department of Ecology \\ Peter Ruggiero, Washington Department of Ecology
}

\section{INTRODUCTION}

This abstract is taken in large part from Gelfenbaum et al. (1999). For much of the past century, and with few exceptions, the shorelines of southwest Washington and northwest Oregon accreted at rates exceeding several meters per year. This widespread accretion resulted in new coastal lands, on which public and private infrastructure and facilities have been built. Several locations that had historically been accreting, however, are presently experiencing severe erosion. The erosion is a critical issue for local governments and state agencies because it threatens significant loss of public and private property. The U.S. Geological Survey and the Washington Department of Ecology initiated a five-year study to address the needs of coastal communities and state and federal agencies, and to 1) understand the regional sediment dynamics, 2) determine the natural and anthropogenic influences on the littoral system, and 3) predict coastal change at management space and time scales (decades and tens of kilometers) (Kaminsky et al., 1997). Major questions being addressed by the study include: Is recent shoreline erosion related to a decrease in sediment supply from the Columbia River?, How do the natural (pre-historic) shoreline change trends compare to the anthropogenic (historic) shoreline change trends?, and How do seasonal and climatic variability effect beach morphology and shoreline change? We can examine these questions using a regional sediment budget approach.

For the last several thousand years the Columbia River has supplied sand to nearby bays (Peterson and Phipps, 1992; Gates, 1994), coastal dunes, the continental shelf (Nittrouer, 1978), the continental slope, submarine canyons and fans (Sternberg, 1986). By quantifying the amount of sand that occupies each of these environments, we will gain a better understanding of the Columbia River dispersal system. We can use this insight to help us better predict the morphological response from changes in the system, whether natural or human-induced. To help separate natural from human-induced changes in the littoral cell, the sediment budget will be calculated for pre-historic periods as well as for historic and recent periods. Since direct measurements of sediment discharge out of the Columbia River estuary do not exist, using the Columbia River littoral cell (CRLC) sediment budget may be a useful means of estimating sediment input from this source. 
The sediment budget presented here is based on a combination of results from ongoing geologic and shoreface-process studies (Gibbs and Gelfenbaum, 1999; Peterson et al., 1999; Ruggiero et al., 1999; Kaminsky et al., 1999) and from earlier work (Sternberg, 1986; Sherwood et al., 1990; Peterson and Phipps, 1992; Gates, 1994; Wolf et al., 1998; Woxell, 1998). Ultimately, a well-developed, quantitative sediment budget for this littoral system will serve as a basis for predictions of future shoreline position based on the sediment supply.

\section{Geological Time Scales}

As sea level rose rapidly from 10-5,000 years ago, shelf and bay accommodation was large and sand accumulated rapidly on the shelf and in the bays. Preliminary calculations of sediment volumes accumulating since the rise of sea level (based on analysis of highresolution seismic data) show $65 \times 10^{9} \mathrm{~m}^{3}$ of sediment on the shelf with the greatest amount near the mouth of the Columbia River and decreasing toward the north and south. These volumes include sand-size and finer material. Averaged over the past 10,000 years, they indicate a mean long-term accumulation rate of $6.5 \times 10^{6} \mathrm{~m}^{3} / \mathrm{yr}$. Sternberg (1986) and Wolf et al. (1999) suggest that an additional $37 \times 10^{9} \mathrm{~m}^{3}$ of Columbia River sediment has accumulated on the continental slopes, canyons, and fans off Washington and Oregon in the last 5,000 years.

Grays Harbor, Willapa Bay and the lower Columbia River basin have been significant sinks of Columbia River sediment as well. Seismic data in Grays Harbor show a 60-70 m deep basin prior to filling by a combination of locally-derived sediment and by Columbia River sand (Peterson and Phipps, 1992). We estimate that accumulation rates of Columbia River sand in Grays Harbor decreased from $0.6 \times 10^{6} \mathrm{~m}^{3} / \mathrm{yr} 7,000$ years ago to $0.2 \times 10^{6} \mathrm{~m}^{3} / \mathrm{yr}$ in the last 5000 years. The total volume of Columbia River sand that has accumulated in Grays Harbor is $4.4 \times 10^{9} \mathrm{~m}^{3}$. Accumulation in Willapa Bay is not yet calculated, but seismic data suggest its basin was one-half the depth of Grays Harbor (Wolf et al., 1998); thus we assume it has less Columbia River sediment in it than Grays Harbor. Stratigraphic evidence indicates that the lower Columbia River valley accumulated sediment at a rate of $8.5 \times 10^{6} \mathrm{~m}^{3} / \mathrm{yr}$ prior to 7,000 years ago, and at a rate of $3.6 \times 10^{6} \mathrm{~m}^{3} / \mathrm{yr}$ in the last 7000 years (Gates, 1994). The total volume of accumulated sediment in the Columbia River valley during the last 10,000 years is $50 \times 10^{9} \mathrm{~m}^{3}$.

As the rate of sea-level rise slowed around 4-5,000 years ago, the barriers adjacent to the Columbia River, at Long Beach and Clatsop, began accumulating sediment and prograded seaward (Woxell, 1998; Peterson et al., 1999). The barriers furthest away from the Columbia River, Grayland and North Beach, began prograding seaward around 2,000 and 1,500 years ago, respectively. Barrier progradation was relatively uniform within each of the sub-cells, whereas among the sub-cells, the pre-historic accumulation rates decreased away from the Columbia River source. Accumulation rates were highest for the Long Beach sub-cell at $0.39 \times 10^{6} \mathrm{~m}^{3} / \mathrm{yr}$ and Clatsop sub-cell at $0.33 \times 10^{6} \mathrm{~m}^{3} / \mathrm{yr}$ and decreased to $0.22 \times 10^{6} \mathrm{~m}^{3} / \mathrm{yr}$ for the Grayland sub-cell and $0.24 \times 10^{6} \mathrm{~m}^{3} / \mathrm{yr}$ for the North Beach sub-cell. Total pre-historical volume accumulation of Columbia River sand for all the barriers in the CRLC was $4.07 \times 10^{9} \mathrm{~m}^{3}$. 
The long-term pre-historical sediment supply over the last 10,000 years from the Columbia River can be estimated by summing the weighted accumulation rates for the different time intervals in the various sedimentary environments of the CRLC (Figure 1). Using the above estimates of sediment accumulation throughout the CRLC, and assuming Willapa Bay filled at half the rate of Grays Harbor, the long-term supply rate of Columbia River sediment to the lower river valley was about $20 \times 10^{6} \mathrm{~m}^{3} / \mathrm{yr}$, and sediment left the estuary at a long-term rate of $15 \times 10^{6} \mathrm{~m}^{3} / \mathrm{yr}$. These supply rates are for total sediment load, including sand, silt, and clay. Further work will allow us to partition the sand from the silt and clay components.

\section{Historical Time Scales}

The Columbia River is the predominant source of sediment for the continental shelf and littoral zones of southwest Washington, but the actual sediment load of the Columbia River has not been adequately measured. Sherwood et al. (1990) used a rating curve (based on USGS measurements at Vancouver, WA in water years 1964-1970) to hindcast sediment discharge from daily river flow measured since 1878 at The Dalles, OR. That estimate has been updated with river flow data through water year 1997. The hindcast calculations indicate that the mean annual sediment (sand) supply to the estuary for 18781997 is $6.6 \times 10^{6}\left(3.0 \times 10^{6}\right) \mathrm{m}^{3} / \mathrm{yr}$. However, with the construction of over 200 dams in the Columbia River drainage basin, regulation of peak river flows has greatly reduced the transport capacity of the Columbia River. Sediment (sand) supply has decreased from $8.7 \times 10^{6}\left(4.3 \times 10^{6}\right) \mathrm{m}^{3} / \mathrm{yr}$ (for the period $1878-1934$, prior to significant flow modification by dams) to $4.3 \times 10^{6}\left(1.4 \times 10^{6}\right) \mathrm{m}^{3} / \mathrm{yr}$ (for the period 1958-1997), a decrease by a factor of 3 for the sand component during historical times.

Not all of the sediment supplied in historical times to the Columbia River Estuary has reached the Pacific Ocean. Approximately $1.8 \times 10^{6} \mathrm{~m}^{3} / \mathrm{yr}$ of fine sand, silt, and clay accumulated in peripheral bays, and upriver channels between 1868 and 1958 (Sherwood et al., 1990). This estimate, based on bathymetric changes, excludes sands that once occupied the flood- and ebb-tidal delta complex. By combining data of Sherwood et al. (1990) with bathymetric-difference calculations of Byrnes and Li (1999), we estimate that the historical accumulation rate in the ebb/flood-tidal delta complex is only about $0.3 \times 10^{6} \mathrm{~m}^{3} / \mathrm{yr}$.

Analysis of historical shoreline positions shows that beach accretion rates increased substantially during early historical periods over pre-historical periods (Woxell, 1998; Kaminsky et al., 1999). The total volume of sand lost or gained due to shoreline change was calculated using a Digital Elevation Model (DEM). The shape of the beach profile is assumed to be constant over time, so any loss or gain of sand moves the entire profile from closure depth up to the height of the dune. Closure depth was estimated as $-15 \mathrm{~m} \mathrm{msl}$ using Birkemeier (1985). Accumulation rates for the early historical period from the $1870 \mathrm{~s}$ to the $1950 \mathrm{~s}$ vary from $1.21 \times 10^{6} \mathrm{~m}^{3} / \mathrm{yr}$ for the Grayland sub-cell to $2.48 \times 10^{6} \mathrm{~m}^{3}$ / $\mathrm{yr}$ for the North Beach sub-cell (Table 1). As with the shoreline-change rates reported in Kaminsky et al. (1999), the accumulation rates are not uniform within the sub-cells. More sand accumulated on the barriers near the entrance to Grays Harbor and the Columbia River than in the center of the sub-cells during the pre-dam historical period. This time 
period includes the construction of the jetties at the entrances to the Columbia River Estuary and Grays Harbor, and is prior to significant modification of the Columbia River drainage basin due to dams. More recently (1950s to 1995), accumulation rates vary from $0.26 \times 10^{6} \mathrm{~m}^{3} / \mathrm{yr}$ for the Grayland sub-cell to $2.10 \times 10^{6} \mathrm{~m}^{3} / \mathrm{yr}$ for Long Beach. Except for the Long Beach sub-cell, where the early and recent historical accumulation rates have stayed about the same, accumulation rates decreased in recent historical time for the Clatsop, Grayland, and North Beach sub-cells. Accumulation rates during the early historical period are 5 to 10 times greater than the long-term pre-historical rates of accretion (Table 1).

We know that the middle and inner shelf of the CRLC has accumulated enormous amounts of Columbia River sediment $\left(\sim 65 \times 10^{9} \mathrm{~m}^{3}\right)$ since the last transgression. Sternberg (1986) sites evidence from Nittrouer (1978) that the modern accumulation rate in the mid-shelf silt deposit is similar to the rate estimated for the last 3,000-7,000 years. There is less evidence of regional accumulation of sand for the inner shelf during historical time. In fact, regional bathymetric change studies conducted by differencing historical hydrographic surveys from the 1870 s and the 1920s suggest that some areas of the inner shelf may have lost sand (Gibbs and Gelfenbaum, 1999). For example, the inner shelf off Grayland was acting as a source of sediment between the 1870s and 1920s, losing $0.81 \times 10^{6} \mathrm{~m}^{3} / \mathrm{yr}$ of sand. Off Long Beach, however, the inner shelf gained sand at a rate of $1.09 \times 10^{6} \mathrm{~m}^{3} / \mathrm{yr}$. The last regional bathymetric survey was in the $1920 \mathrm{~s}$, so it is unknown how the inner shelf has responded over the last 70 years.

Estimates of the sediment budget of the CRLC during historical times must consider direct human-induced transport of sand. The U.S. Army Corps of Engineers dredges an average of $3.41 \times 10^{6} \mathrm{~m}^{3} / \mathrm{yr}$ of sand from the lower estuary (U.S. Army Engineer District, Portland, 1998). The dredged sand is placed in disposal sites inside the estuary, in the entrance, and offshore. Dredging records since 1956 reveal that the majority of sand, approximately $2.1 \times 10^{6} \mathrm{~m}^{3} / \mathrm{yr}$, is moved to offshore disposal sites. These offshore sites are on various parts of the ebb-tidal delta in water depths ranging from 15 to $55 \mathrm{~m}$. An unknown amount of the sand placed on the ebb-tidal delta may be transported back into the estuary. The amount of dredged material that stays in the active littoral zone is unknown. Although side-scan sonar records taken in the mouth of the Columbia River estuary (Sherwood and Creager, 1990) reveal both upstream and downstream oriented bed forms, net transport at the mouth has not been directly measured.

\section{CONCLUSION}

Although the sediment budget presented here is preliminary and much work is needed to quantify all the compartments and pathways of the CRLC, several observations can be drawn from our analysis.

1) The majority of Columbia River sediment has accumulated on the continental shelf, in the deep sea, and in the estuaries. The amount in the beaches, by comparison, is smaller. 
2) Average sediment supply from the Columbia River was apparently much greater for the last 10,000 years than it is now, possibly reflecting the contribution of several unmitigated volcanic eruptions, erosion of glacial deposits, and extreme floods.

3) Early historical shoreline accretion rates are much greater than pre-historical rates, and in general, greater than recent accretion rates. The timing of the rapid accretion in the early part of the century and the longshore variation in the accretion suggest changes in the ebb-tidal deltas after jetty construction as the primary source of sand to the barriers.

4) Ebb-tidal deltas and the inner shelf may act as temporary sources of sediment to the beaches.

5) Sediment supply from the Columbia River to the estuary has likely been reduced over the last several decades due to reduction in transport capacity resulting from flow regulation, and possible direct trapping behind dams.

6) The volume of dredged material placed at the mouth of the Columbia River is large compared to long-term changes in the tidal-delta complex.

Questions remaining to be resolved:

1) What is the exchange of sediment, if any, between the inner shelf and the beaches?

2) Are Grays Harbor and Willapa Bay presently accumulating Columbia River sediment or have they reached equilibrium?

3) Is the inner shelf still accumulating Columbia River sediment as it has in the past, or is it stable, or perhaps a source to another sedimentary environment in the CRLC?

4) How much of the dredged material disposed near the mouth of the Columbia River is available to the littoral cell?

5) Has the supply of sediment from the Columbia River stabilized, and how long does it take the littoral system to adjust to changes in supply?

\section{REFERENCES}

Birkemeier, W.A. 1985. Field data on the seaward limit of profile change, Journal of Waterway, Port, Coastal and Ocean Engineering, 111, pp. 598-602.

Byrnes, M.R., and Li, F. 1999. Regional Analysis of Sediment Transport and Dredged Material Dispersal Patterns, Columbia River Mouth, Washington/Oregon, and Adjacent Shores, Draft Final Report Prepared for the USAE Waterways Experiment Station, Applied Coastal Research and Engineering, Mashpee, Massachusetts, 45 p. 
Gates, E.B. 1994. The Holocene Sedimentary Framework of the Lower Columbia River Basin, M. S. Thesis, Portland State University, Portland, Oregon.

Gelfenbaum, G., Sherwood, C.R., Peterson, C.D., Kaminsky, G., Buijsman, M., Twichell, D., Ruggiero, P., Gibbs, A., and Reed, C. 1999. The Columbia River littoral cell: A sediment budget overview, Proceedings of Coastal Sediments '99, ASCE, pp. 1660-1675.

Gibbs, A., and Gelfenbaum, G. 1999. Bathymetric change off the Washington-Oregon coast, Proceedings of Coastal Sediments '99, ASCE, pp. 1627-1642.

Kaminsky, G.M., Buijsman, M.C, Gelfenbaum, G., Ruggiero, P., Jol, H.M., Gibbs, A.E., and Peterson, C.D. 1999. Synthesizing geological observations and processesresponse data for modeling coastal change at management scale, Proceedings of Coastal Sediments '99, ASCE, pp. 1708-1723.

Kaminsky, G.M., Daniels, R.C., Huxford, R., McCandless, D., and Ruggiero, P. 1999. Mapping erosion hazards in Pacific County, Washington, Journal of Coastal Research, Special Issue 28, pp. 158-170.

Kaminsky, G.M., Ruggiero, P. Gelfenbaum, G., and Peterson, C. 1997. Long-term coastal evolution and regional dynamics of US Pacific Northwest littoral cell, Proceedings of Coastal Dynamics '97, The International Conference on Coastal Research through Large Scale Experiments, pp. 614-623.

Nittrouer, C.A. 1978. The Process of Detrital Sediment Accumulation in a Continental Shelf Environment: An Examination of the Washington Shelf, Ph.D. Thesis, University of Washington, Seattle, Washington.

Peterson, C.D., Gelfenbaum, G., Jol, H.M., Phipps, J.B., Reckendorf, F., Twichell, D.C., Vanderburgh, S., and Woxell, L. 1999. Great earthquakes, abundant sand, and high wave energy in the Columbia cell, USA, Proceedings of Coastal Sediments '99, ASCE, pp. 1676-1691.

Peterson, C.D., and Phipps, J.B. 1992. Holocene sedimentary framework of Grays Harbor Basin, Washington, USA, SEPM Special Pub. No. 48, SEPM (Society for Sedimentary Geology), pp. 273-285.

Ruggiero, P., Côté, J., Kaminsky, G., and Gelfenbaum, G. 1999. Scales of variability along the Columbia River littoral cell, Proceedings of Coastal Sediments '99, ASCE, pp. 1692-1707.

Sherwood, C.R., and Creager, J.S. 1990. Sedimentary geology of the Columbia River Estuary, Progress in Oceanography, 25(1-4), pp. 15-79. 
Sherwood, C.R., Jay, D.A., Harvey, R.B., Hamilton, P., and Simenstad, C.A. 1990. Historical changes in the Columbia River Estuary, Progress in Oceanography, 25, pp. 299-352.

Sternberg, R.W. 1986. Transport and accumulation of river-derived sediment on the Washington continental shelf, USA, Journal of the Geological Society, London, 143, pp. 945-956.

U. S. Army Engineer Portland District 1998. Draft Integrated Feasibility Report for Channel Improvements and Environmental Impact Statement: Columbia and Lower Willamette River Federal Navigation Channel, U.S. Army Corps of Engineers, Portland District, Portland, Oregon.

Wolf, S.C., McCrory, P.A., and Hamer, M.R. 1998. Investigation of Late Quaternary Geologic Features in Willapa Bay, Washington, U. S. Geological Survey Open-File Report 98-589.

Wolf, S.C., Nelson, H., Hamer, M.R., Dunhill, G., and Phillips, R.L. 1999. The Washington and Oregon Mid-Shelf Silt Deposit and Its Relation to the Late Holocene Columbia River Sediment Budget, U. S. Geological Survey Open-File Report 99-173.

Woxell, L.K. 1998. Prehistoric Beach Accretion Rates and Long-Term Response to Sediment Depletion in the Columbia River Littoral System, USA, M.S. Thesis, Portland State University, Portland, Oregon, 206 p.

Table 1. Accumulation rates of Columbia River sand on the barrier of each sub-cell.

\begin{tabular}{|c|c|c|c|}
\hline \multirow[b]{3}{*}{$\begin{array}{l}\text { Barrier } \\
\text { Sub-Cell }\end{array}$} & \multicolumn{3}{|c|}{ Sediment Accumulation Rate (x $\left.10^{6} \mathrm{~m}^{3} / \mathrm{yr}\right)$} \\
\hline & \multirow[t]{2}{*}{$\begin{array}{c}\text { Pre-Historical }{ }^{*} \text { (since start of } \\
\text { barrier accretion) }\end{array}$} & \multicolumn{2}{|c|}{ Historical } \\
\hline & & $(1870 s-1950 s)$ & $(1950 s-1995)$ \\
\hline Clatsop & 0.33 & 2.01 & 0.57 \\
\hline $\begin{array}{l}\text { Long } \\
\text { Beach }\end{array}$ & 0.39 & 1.98 & 2.10 \\
\hline Grayland & 0.22 & 1.21 & 0.26 \\
\hline $\begin{array}{l}\text { North } \\
\text { Beach }\end{array}$ & 0.24 & 2.48 & 1.43 \\
\hline
\end{tabular}




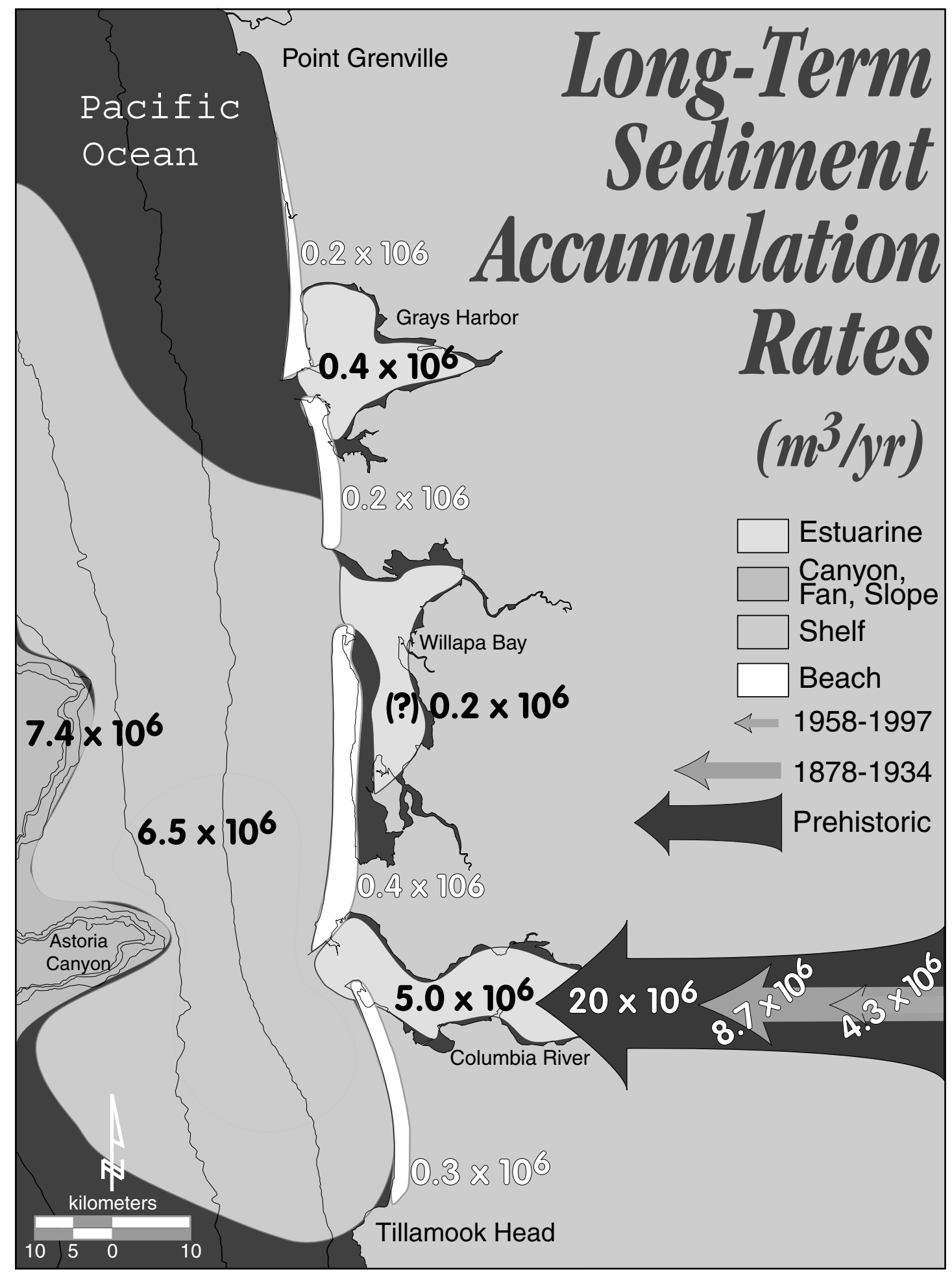

Figure 1. Long-term sediment accumulations rates for the CRLC. 


\title{
EVALUATING COASTAL SUSCEPTIBILITY, WORKING TOWARD A DECISION SUPPORT SYSTEM
}

\author{
Brian Voigt, Washington Department of Ecology \\ Peter Ruggiero, Washington Department of Ecology \\ George Kaminsky, Washington Department of Ecology
}

\begin{abstract}
One of the primary goals of the Southwest Washington Coastal Erosion Study is to understand and predict coastal change at time and space scales relevant to coastal management (decades \& tens of kilometers) (Kaminsky et al., 1999). As our understanding of the complex Columbia River littoral cell system increases, Study results will be examined as part of a larger framework to identify areas of coast susceptible to morphological change. The outcomes of the susceptibility analyses will lead to a formalization of Study results through the development of decision support products. These tools will assist coastal managers with the consideration of scientific knowledge as part of the planning and decision-making processes.
\end{abstract}

\section{SUSCEPTIBILITY FRAMEWORK}

The process of knowledge formalization progresses through four stages as denoted along the left edge of Figure 1, beginning with the data phase, then building an information base, developing a knowledge base through characterization of the area of interest, and, finally, formalizing that knowledge as part of an experience base (Capobianco et al., 1999). In the data phase, the problem is defined in cooperation with the end-user community, and background research is performed, including the identification of available resources and initiation of data collection and recovery efforts.

The Southwest Washington Coastal Erosion Study was begun in May 1996. The sequence of events that led to the initiation of the Study identified a critical lack of available information to support the decision-making process. The information phase represents organization and analysis of the results of the data phase. As information is developed, uncertainties should be noted when prioritizing future research. While some uncertainty can be accounted for simply by collecting additional data, it is not always cost-effective to do so. Predictive uncertainties, on the other hand, may best be dealt with via sensitivity analyses that evaluate changes in model outputs based on varying input parameters (Cowell et al., 1994). One of the greatest challenges to this process lies in understanding and managing the uncertainties that will ultimately affect decision-making outcomes.

The knowledge base will expand on the data synthesis and integration component of the information phase. A conceptual model of the littoral cell system is currently under development as a means of representing the littoral cell sediment budget over several time scales (Gelfenbaum et al., 1999). Additional efforts in this phase include working with end-users to develop model input forcing scenarios with temporal and spatial constraints 
that reflect issues of local concern. Continued monitoring of coastal conditions (Ruggiero et al., 1999) will serve as an effective means of evaluating initial results and improving modeling processes. The knowledge phase results in output variables that quantify the physical vulnerability/resilience of the littoral system. These variables lead to a formalization of knowledge in the experience phase. This formalized knowledge will be transferred to the end-user community through the development of management support tools that facilitate the integration of available scientific knowledge with the decisionmaking process. Management support products might include tools such as maps, reports, databases, an interactive GIS, or technical assistance. It is critical that Study investigators work in cooperation with the end-user community to ensure the development of useful and relevant products which address relevant issues and priority planning efforts. Further, combining physical susceptibility outcomes with relevant data from the ecological, social and economic disciplines will quantify the impacts of physical change on the socioeconomic system. The integration of multi-disciplinary data sets will facilitate sciencebased management that addresses community issues and identifies priority areas for planning consideration based on acceptable levels of risk.

While the development of management oriented products is a tangible outcome of the susceptibility framework, perhaps equally important is the experience gained through the application of knowledge to specific coastal planning problems. Evaluating the results of scientific based decisions in relation to acceptable versus actual outcomes will help refine the decision-making process and identify shortcomings in our scientific understanding of littoral cell evolution.

\section{ASSESSING COMMUNITY NEEDS}

In an effort to strengthen the Study's coordination with coastal communities, a proposal has been developed to conduct an assessment of local community coastal management needs. The application was successfully submitted to the Department of Ecology for Coastal Zone Management 306 funding. The proposed project will determine local community coastal management information needs and develop modern decision-support tools to improve the integration of scientific knowledge with the local management framework. The grant will focus on three priority tasks, including conducting an assessment of technical capacity and information needs, developing a prototype interactive CD-ROM that addresses the informational needs of the coastal management community, and disseminating information and GIS map products that form the basis of a local decision-support framework via the Internet.

\section{REFERENCES}

Capobianco, M., DeVriend, H.J., Nicholls, R.J., and Stive, M.J.F. 1999. Coastal area impact and vulnerability assessment: The point of view of a morphodynamic modeller, Journal of Coastal Research, 15, pp. 701-716. 
Cowell, P.J., and Thom, B.G. 1994. Coastal impacts of climate change - modelling procedures for use in local government, Proceedings of the 1st National Coastal Management Conference, Coast to Coast'94, pp. 43-50.

Gelfenbaum, G., Sherwood, C.R., Peterson, C.D., Kaminsky, G.M., Buijsman, M., Twichell, D.C., Ruggiero, P., Gibbs, A.E., and Reed, C. 1999. The Columbia River littoral cell: A sediment budget overview, Proceedings of Coastal Sediments '99, ASCE, pp. 1660-1675.

Kaminsky, G.M., Buijsman, M., Gelfenbaum, G.R., Ruggiero, P., Jol, H.M., Gibbs, A., and Peterson, C.D. 1999. Synthesizing geological observations and processresponse data for modeling coastal change at a management scale, Proceedings of Coastal Sediments '99, ASCE, pp. 1708-1723.

Ruggiero, P., Côté, J., Kaminsky, G.M., and Gelfenbaum, G.R. 1999. Scales of variability along the Columbia River littoral cell, Proceedings of Coastal Sediments '99, ASCE, pp. 1692-1707. 


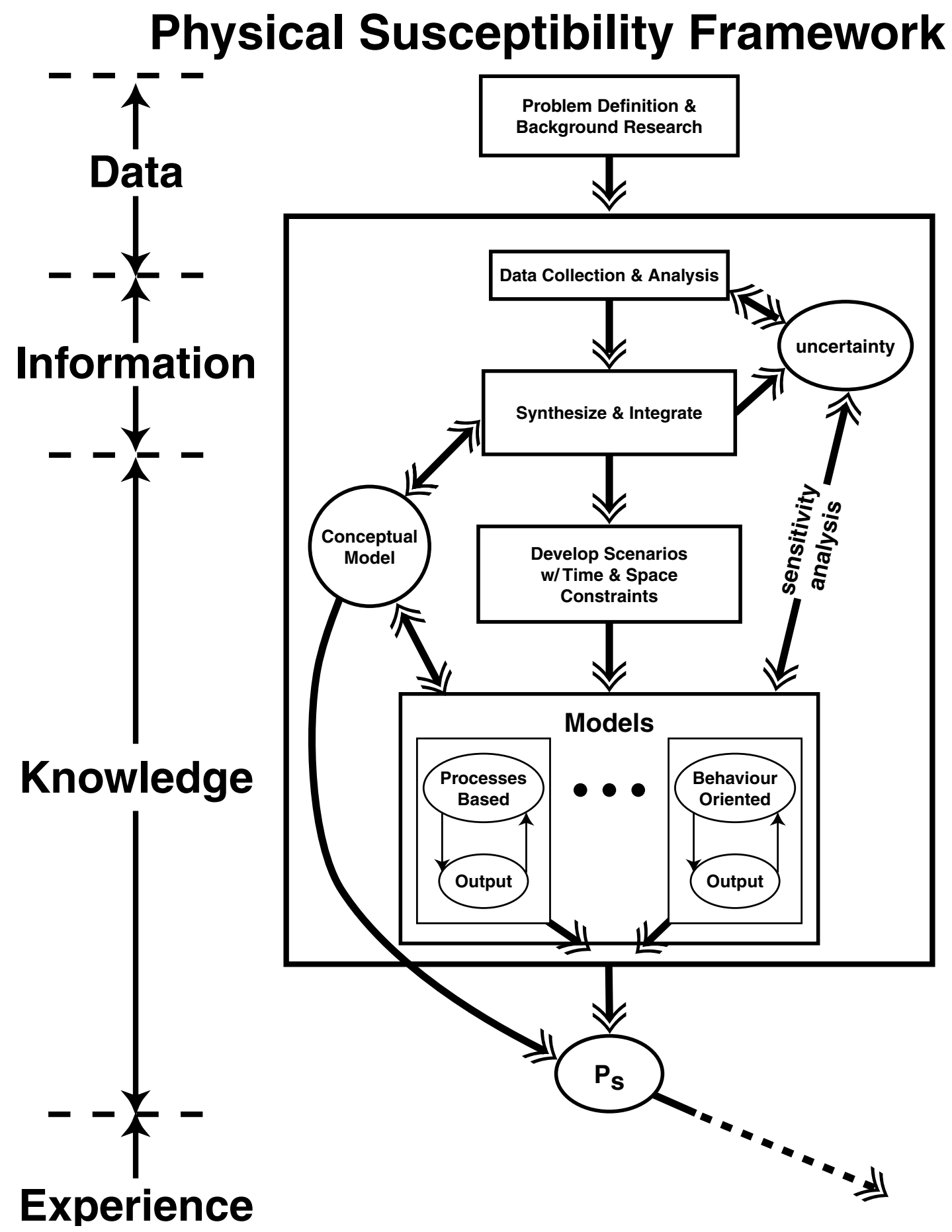

Figure 1. Flow diagram for evaluating susceptibility to coastal change in the Columbia River littoral cell. Framework outputs will be developed into formalized knowledge that feed into the decision making process. 


\section{SEDIMENT SIZE DISTRIBUTION WITHIN THE COLUMBIA RIVER LITTORAL CELL}

Emily Lindstrum, Washington Department of Ecology

Peter Ruggiero, Washington Department of Ecology

Jerry Franklin, Washington Department of Ecology

Dave Twichell, U.S. Geological Survey

George Kaminsky, Washington Department of Ecology

\section{INTRODUCTION}

As part of the beach morphology monitoring program of the Southwest Washington Coastal Erosion Study, sediment samples have been collected in conjunction with both onshore and nearshore beach profiles. Four sets of sediment samples have been gathered: summer 1997, winter 1998, summer 1998, and summer 1999. The onshore samples are located at each of the 47 beach profile locations and consist of a dune, dune-toe, midbeach, and a swash sample at low tide. Offshore samples were collected during the nearshore bathymetric surveys of summer 1998 and 1999. These samples were obtained using an Ekman Grab in water depths of up to 12 meters.

Samples have been analyzed using a Ro-tap sieve shaker and sieve screens of phi range -3.0 through 4.0 in $1 / 4$ phi intervals. Presently, the mid-beach samples from summer 1997, 1998, and 1999 have been analyzed, along with the offshore samples from 1998 and 1999. Both the graphical method and the method of moments for calculating sediment statistics have been employed.

These sediment data have been compiled with other available data sets to create a GIS product of sample locations and statistics throughout the Columbia River littoral cell (CRLC). These GIS layers include offshore data from the USGS summer 1997 and 1998 cruises as well as the University of Washington, Department of Oceanography cruises of 1966 and 1967. A partial list of available data sources is given in Table 1. The authors of this work welcome feedback on the completeness of this compilation exercise. The ultimate goal of this project is to create a central database of all existing sediment data as well as a GIS tool for visualizing and analyzing the data. Figure 2 represents the initial development of this product by displaying the location of several of the samples listed in Table 1 along with median grain size.

\section{CONCLUSIONS}

Sediment analysis of summer 1998 onshore mid-beach samples from the 47 profiles reveal a trend of decreasing median grain size with distance from the mouth of Columbia River (Figure 1). This trend is positively correlated with mean beach slopes along the CRLC. The main outlier of these trends exist near Grays Harbor where the beaches have the highest median grain size and mean beach slope within the CRLC. A temporal comparison of the median grain size from mid-beach samples collected during summer 
1998 and summer 1999 is shown in Figure 3. The right hand panel illustrates the difference between median grain size over this time period. Of the 46 sites 20 show a positive difference, i.e. these sites had coarser sediments in 1999 than in 1998. 26 of the 46 sites experienced a decrease in median grain size over this same period.

A cross-shore representation of sediment grain size variability, from the dune to 25 meters NAVD 88, is shown in Figure 4 for Grayland Plains at cross-shore profile site PRUG. Sediment data reveals the finest samples found on this profile are between -9 and -14 meters with coarser sediment both offshore and onshore. A trend of sediment fining is evident from the swash zone landward to the dune. The sediment data included in this profile is a composite derived from several field campaigns using a variety of techniques. The approximate cross-shore location of sediment samples has been superimposed on the figure along with median grain size. Actual sample locations may be plus or minus one kilometer from the alongshore position of this transect.

\section{REFERENCES}

Burnett, T.L.,Jr. 1967. Bottom sediment data from the continental shelf of WashingtonGrays Harbor to Cape Flattery: Special Report No. 39, University of Washington Dept. of Oceanography, Volume I, II, and III, Seattle, Washington. 

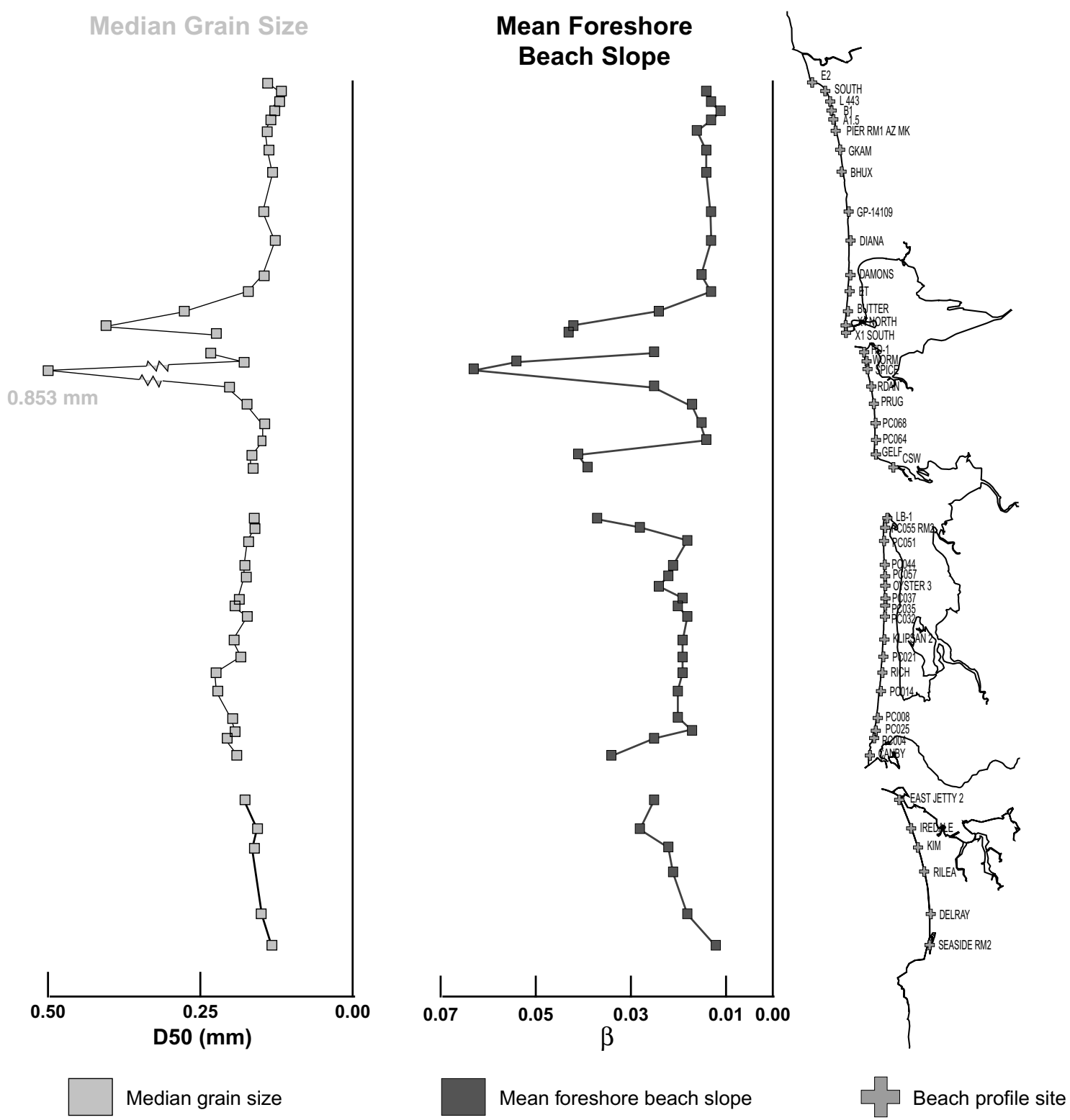

Figure 1. A) Median grain size, D50 ( $\mathrm{mm})$ and B) mean beach slopes, $\beta$ (radians), at each of the 47 beach profile locations. Beach slopes are foreshore slopes, calculated between the 1.0 and $3.0 \mathrm{~m}$ contours (NAVD 88), and are averaged from 3 surveys: summer 1997, winter 1998, and summer 1998. 


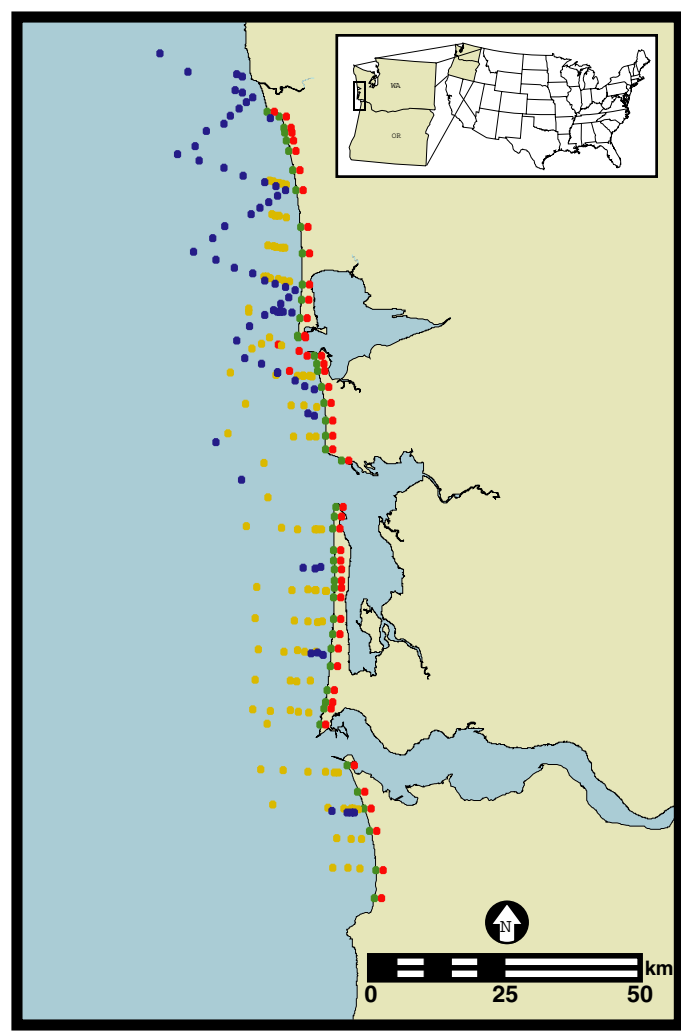

Data Source

University of Washington

USGS
CMAP 1998

CMAP 1999

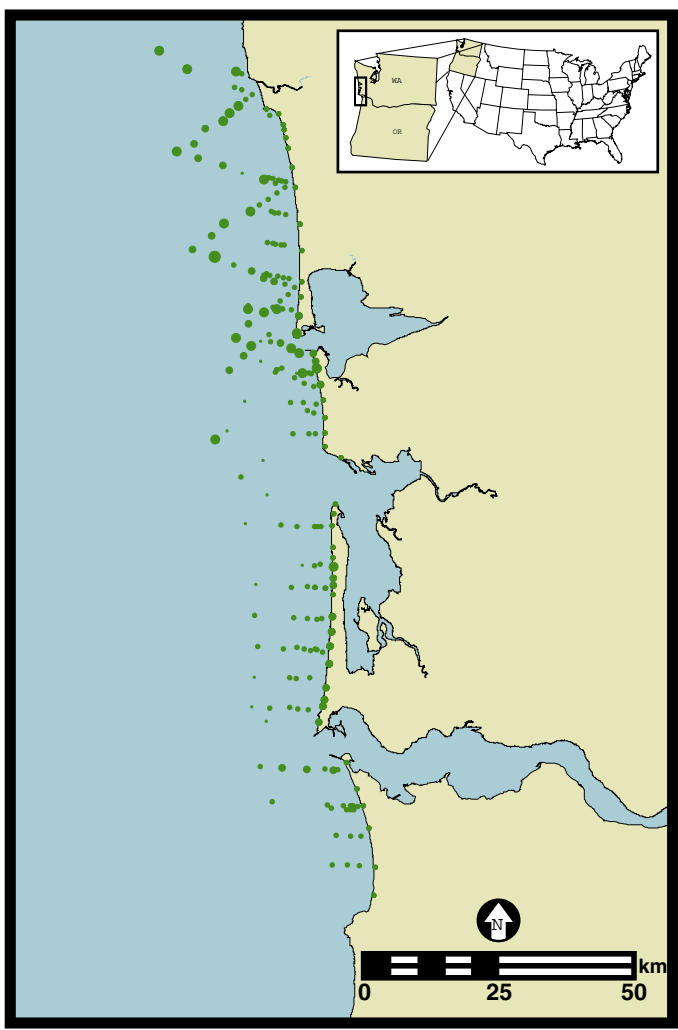

Grain Size

- 4 - $12 \mathrm{phi}$

3 - $3.75 \mathrm{phi}$

- $1.5-2.75 \mathrm{phi}$

$-2.25-1.25 \mathrm{phi}$

$-5--2.5 \mathrm{phi}$

phi $=-\log _{2}$

Figure 2. A) Sediment grain size distribution data sources and locations. B) Median sediment diameter (phi scale) from several of the sources listed in Table 1. The phi scale divisions include fine grain sand or soil, fine sand, medium fine sand, coarse to medium sand, and fine gravel to boulder. Sediment samples were categorized using the Unified Soil Classification System. 

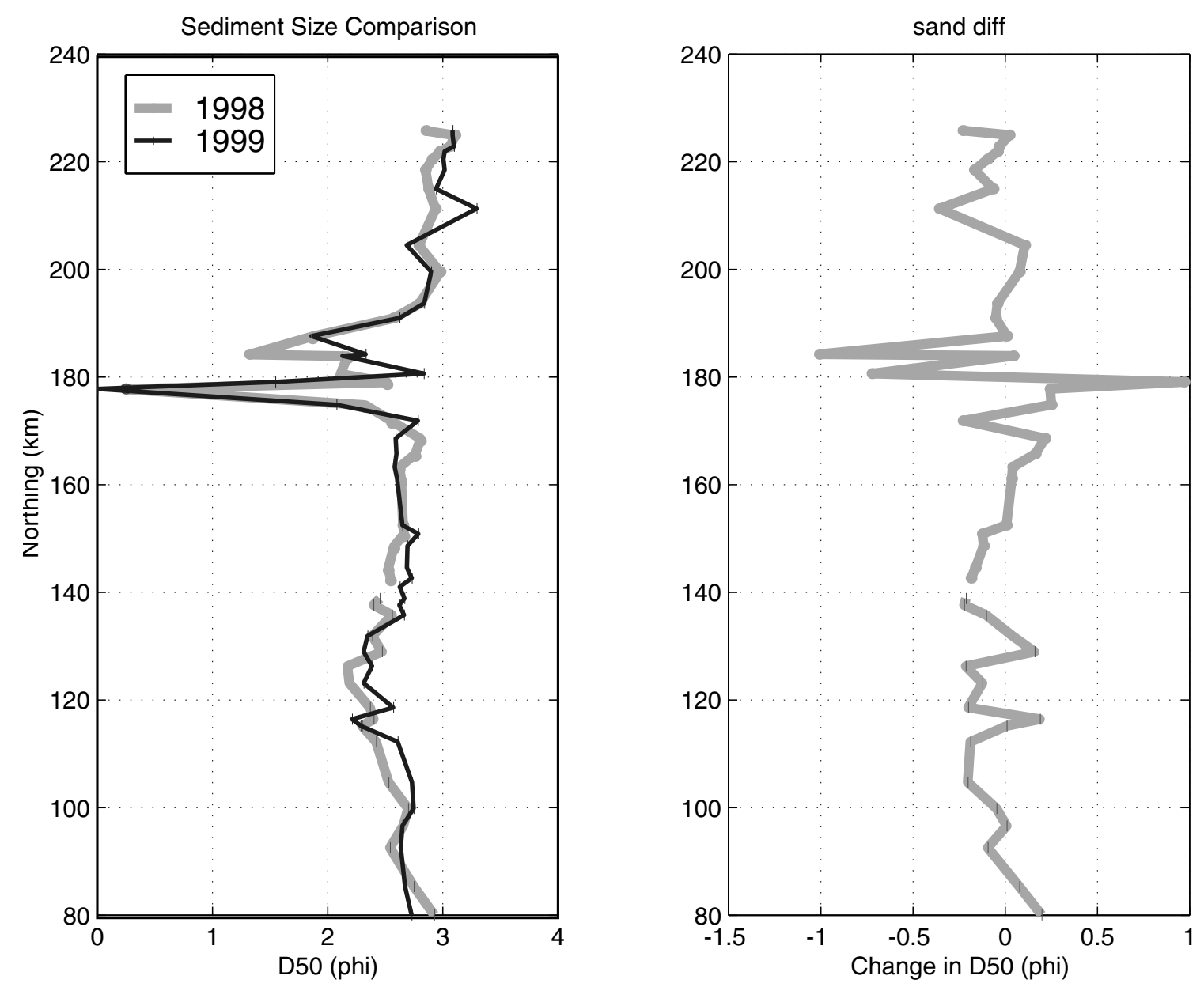

Figure 3. Median sediment diameter from mid-beach samples collected during summer 1998 and summer 1999 as part of the SWCES beach morphology monitoring program. The right panel illustrates the difference in median grain size over this time period. Of the 46 total sites 20 of the sites had a coarser median grain size and 26 had a finer median grain size in 1999 than in 1998. 


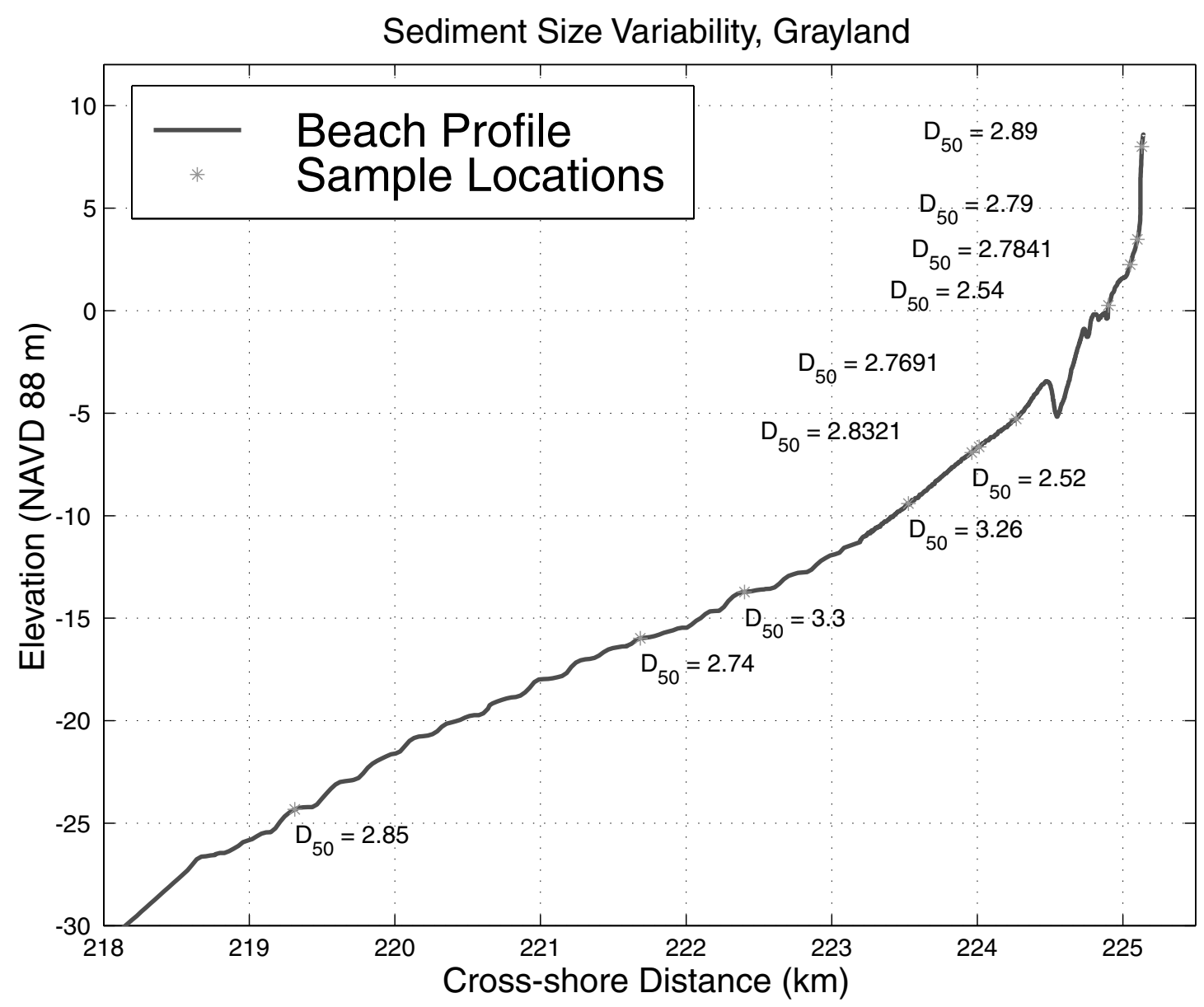

Figure 4. Sediment grain size variability along a cross-shore beach profile in Grayland, Washington. Sediment samples from alongshore locations of plus or minus one kilometer from transect (PRUG) have been superimposed on the figure to reveal trends in sediment size. The finest samples on this line are between 9 and 14 meters NAVD 88 with coarser sediment both offshore and onshore. A trend of sediment fining is evident from the swash zone landward to the dune. 
Table 1. This is a partial compilation of sediment size distribution data in the CRLC from several sources.

\begin{tabular}{|c|c|c|}
\hline Date & Project & Investigator \\
\hline June-Sept. 1997 & SWCES & CMAP \\
\hline Jan.-Feb. 1998 & SWCES & CMAP \\
\hline June-Sept. 1998 & SWCES & CMAP \\
\hline Aug.-Sept. 1998 & SWCES & Dave Twichell \\
\hline June-Sept. 1999 & SWCES & CMAP \\
\hline 1994 & $\begin{array}{l}\text { Cascadia beach shoreline database, } \\
\text { Pacific Northwest Region, USA, State of } \\
\text { Oregon Department of Geology and Mineral } \\
\text { Resources, Open File Report 0-94-2. }\end{array}$ & $\begin{array}{l}\text { Peterson, C.D., M.E. } \\
\text { Darienzo, D.H. Hamilton, } \\
\text { D.J. Pettit, and R.K. } \\
\text { Yeager. }\end{array}$ \\
\hline Oct.-Nov. 1946 & $\begin{array}{l}\text { Beach and Surf Conditions on the Oregon } \\
\text { and Washington coasts in } 1946\end{array}$ & $\begin{array}{l}\text { Bascom, W. N. } \\
\text { University of California, } \\
\text { Inst. of Engineering } \\
\text { Research }\end{array}$ \\
\hline Aug.-Sept. 1945 & $\begin{array}{l}\text { Beach and Surf Conditions on the Oregon } \\
\text { and Washington coasts in } 1945\end{array}$ & $\begin{array}{l}\text { Isaacs, J. D. } \\
\text { University of California, } \\
\text { Inst. of Engineering } \\
\text { Research }\end{array}$ \\
\hline $\begin{array}{l}\text { July-Aug. } 1966 \text { \& } \\
1967\end{array}$ & $\begin{array}{l}\text { Bottom Sediment Data from the Continental } \\
\text { Shelf of Washington- Grays Harbor to Cape } \\
\text { Flattery Volumes I, II, and III }\end{array}$ & $\begin{array}{l}\text { University of Washington } \\
\text { Department of } \\
\text { Oceanography } \\
\text { Burnett, T. L., Jr. }\end{array}$ \\
\hline October 1974 & $\begin{array}{l}\text { Marine Sedimentological Data of the } \\
\text { Washington Continental Shelf }\end{array}$ & $\begin{array}{l}\text { University of Washington } \\
\text { Department of } \\
\text { Oceanography } \\
\text { Robert, R. W }\end{array}$ \\
\hline August- Sept. 1945 & $\begin{array}{l}\text { Distribution of Beach Sediment Near the } \\
\text { Columbia River }\end{array}$ & $\begin{array}{l}\text { University of Washington } \\
\text { Department of } \\
\text { Oceanography } \\
\text { Ballard, R. L. }\end{array}$ \\
\hline
\end{tabular}




\section{MEDIUM- LARGE-SCALE NEARSHORE MORPHOLOGIC VARIABILITY ALONG THE COLUMBIA RIVER LITTORAL CELL}

Peter Ruggiero, Washington Department of Ecology

Guy Gelfenbaum, U.S. Geological Survey

Jamie MacMahan, University of Florida

George Kaminsky, Washington Department of Ecology

\section{INTRODUCTION}

As a component of the Southwest Washington Coastal Erosion Study (SWCES) beach morphology-monitoring program, nearshore beach profiles have been surveyed along a majority of the 165-km Columbia River littoral cell (CRLC). More than 240 (Figure 1) cross-shore profiles were collected in the summer of 1999 using a second generation Coastal Profiling System, a conventional bathymetric survey system configured on a personal watercraft with demonstrated sub-decimeter vertical accuracy. Each profile extends from the shoreline to a deep-water limit ranging between 9 and 15 m (NAVD 88). Many of the bathymetric profiles have been combined with topographic surveys, extending the profiles landward to the dune fields. Also, along a $25-\mathrm{km}$ subset of the region, the profiles have been supplemented with a high resolution multi-beam (swath) bathymetry data set, extending the transects to over $40 \mathrm{~m}$ water depth, covering the entire nearshore planform (Flood, this volume). The alongshore distance between profiles varies between $200 \mathrm{~m}$ to $1000 \mathrm{~m}$, a sampling scheme designed to measure medium- to largescale variability in nearshore morphology. Table 1 lists the environmental conditions during the eight week 1999 field campaign.

\section{SURVEY SYSTEM}

The U.S. Geological Survey, in cooperation with the Washington Department of Ecology and the University of Florida, has recently built and tested a new system to collect bathymetric data in energetic, nearshore environments. Based on the Coastal Profiling System developed by Oregon State University (Côté et al., in review), the USGS system is comprised of a waverunner, which has been equipped with an echo sounder, GPS receiver and antenna, and on-board computer running navigation software. The waverunner is a Yamaha Wave Venture 700, which is large, powerful, and stable. The echo sounder is an Oceandata Bathy 500 in which the paper recorder has been removed and the acquisition and processing boards have been mounted in a waterproof box underneath the seat. For precise horizontal and vertical positioning a Trimble 4700 GPS receiver is operated in Real-Time-Kinematic (RTK) mode. The GPS antenna is mounted on the waverunner directly above the echo sounder. The GPS receiver is also enclosed in a waterproof box and stored underneath the seat. The GPS base station is set up on a benchmark on land to provide a land-based vertical datum. The GPS and echo sounder data are delivered to the navigation and data acquisition software, Hypack, which is running on a Libretto laptop computer, which is also stored underneath the seat. A monitor is housed in a waterproof box and mounted above the handlebars, along with a waterproof keypad. The entire 
system is run off of two 12-volt batteries, operating in parallel, that are also housed in a waterproof box and attached to a mount on the back of the boat.

A waverunner is the optimal boat for collecting nearshore bathymetry through the surf zone. The boats operate with a jet propulsion system, so they are safer and have a shallower draft than a propeller-driven system. The boats are extremely maneuverable and can be easily righted after they flip over. The echo sounder operates at $8 \mathrm{~Hz}$ and the GPS at $5 \mathrm{~Hz}$, so surface waves are resolved and accounted for in the data.

\section{DATA}

Cross-shore beach profiles were collected in the onshore direction to minimize the impact of waves. Following collection, raw data files were first screened to eliminate periods when the GPS was not initialized in RTK mode. The data were then brought back into Hypack to combine the GPS and echo sounder data. Individual profiles were visualized in Hypack allowing for the elimination of obvious outliers. The combined data were then exported to an ASCII format for further processing, such as an adjustment for speed of sound and profile smoothing. During data collection, the speed of sound was held constant. Although not precisely measured during the field campaigns, water temperature measurements from offshore wave buoys (see Table 1) during the summer were used to estimate the speed of sound during the individual data runs. These SOS values were then used to adjust the profiles. The profiles were then smoothed, as wave motions still affect the measurements at decimeter scale, using a median-filter algorithm that averages data along approximately a 10-m distance in the cross-shore.

The dominant characteristic of the nearshore morphology data collected during 1998 and 1999 is spatial variability. The profiles have between 0 and 4 bars, ranging in height from approximately $0.2 \mathrm{~m}$ to a remarkable $6.0 \mathrm{~m}$ as measured from the seaward crest to landward trough. The cross-shore length scale of the bar crest position varies from $\mathrm{O}(100 \mathrm{~m})$ for inner swash bars and to $\mathrm{O}(1000 \mathrm{~m})$ for outer bars. Typically one or more middle bars is also present on the profiles. The water depth at the outer bar crest ranges from $5.0-8.5 \mathrm{~m}$ (when present), 3.0 -5.0 $\mathrm{m}$ for the middle bar and 0.0-1.5 $\mathrm{m}$ for the inner bars. Four example cross-shore profiles from the Long Beach sub-cell (collected in 1999) are shown in Figure 2, revealing the variability in the number of bars, bar height, and bar position.

\section{Medium-scale Variability}

Within each of the four sub-cells of the CRLC, a $1.5 \mathrm{~km}-3.0 \mathrm{~km}$ section of coast has been surveyed in both 1998 and 1999, with $200 \mathrm{~m}$ profile spacing to resolve medium-scale morphology. Figure 3 shows alongshore-averaged profiles for the Long Beach (Oysterville) surface (Figure 1). The data reveal a large redistribution of sediment in the cross-shore, the growth of a large outer bar, landward migration of the middle bar and no shoreline change. Over the $2.5 \mathrm{~km}$ (both in the cross-shore and alongshore) surface there was no appreciable loss of sediment from 1998 to 1999. However, in the cross-shore, beach profile change out to $10 \mathrm{~m}$ (NAVD 88 ) was measured. The spatial variability of bar height and the change over one year is illustrated in Figure 4. The most striking feature in 
this plot is the growth of the outer bar between 1998 and 1999. Change in bar crest position is shown in Figure 5, revealing the onshore migration of both the outer and middle bar during this period.

The nearshore morphology of the other sub-cells within the CRLC is quite different than that of Long Beach. For example, the nearshore planform of Grayland Plains is virtually 1-dimensional. Only occasionally do the profiles in Grayland show appreciable bar formation. Figure 6 is a comparison between the alongshore-averaged profile from the Long Beach medium-scale surface with an alongshore-averaged profile from approximately $2.0-\mathrm{km}$ of Grayland data. The profiles have each been translated such that the $2.0-\mathrm{m}$ contour is at a cross-shore position of 0.0 in order to compare beach slopes and bar properties. The Grayland surface is steeper and devoid of sandbars. This Grayland surface experienced a net vertical loss of approximately $0.25 \mathrm{~m}$ along the profile from 1998 to 1999 . This quantity translates to approximately $1.0 \times 10^{6} \mathrm{~m}^{3}$ of erosion over this $2.0-\mathrm{km}$ stretch, presumably to the south.

\section{Large-scale Variability}

Along much of the remainder of the individual sub-cells, profiles were collected at 1000-m intervals. Figure 7 reveals bar statistics for over $25 \mathrm{~km}$ of Long Beach shoreline. A continuous outer bar is evident that extends from North Head (km 114) north for approximately $20 \mathrm{~km}$. The bar trends offshore relative to the shoreline with the water depth at the bar crest increasing until the bar disappears. The former middle bar (in the alongshore, not temporal sense) becomes the new outer bar at $\mathrm{km} 131$ with a similar offshore trend. The height of the outer bar has no pronounced trend, however, the magnitudes of the heights are some of the largest ever observed.

Figure 8 further illustrates the variability between sub-cells. The behaviour of the North Beach sub-cell is closer to that of Long Beach than its neighbor in both the magnitude and variability of the nearshore morphology. These data reveal drastic variability in the largescale behaviour both within a particular sub-cell and over the entire region.

\section{SCALING OF BAR PROPERTIES}

The nearshore planform observed in these data range from a fairly linear bar system to complex three-dimensional morphology. Simple sand bar generation models are unable to explain this variability in morphology; however, scaling relationships may aid in determining the dominant processes responsible for the observations. For example, using the standard scaling arguments for the infragravity-wave bar generation model (Holman and Sallenger, 1993), a standing wave with a period of over $300 \mathrm{~s}$ would be required to generate a bar over $1000 \mathrm{~m}$ from the shoreline on the low sloping dissipative beaches of the CRLC.

$$
x_{i}=\frac{g T^{2} \beta}{4 \pi^{2}} \chi_{1}
$$


In this relationship, $x_{i}$ is the cross-shore position of the bar as forced by nodes in the crossshore velocity of either edge waves or leaky waves, $g$ is the acceleration due to gravity, $T$ is the period of the standing wave, $\beta$ is the beach slope (approximately 1/150) and $\chi 1$ is the first zero of the edge wave equation solution (typically about 4.5). No data exists at present to either support or refute this long wave mechanism, however, Oltman-Shay et $a l ., 1998$, suggest that extremely low frequency motions do exist in the inner surf zone on Washington beaches. An alternative bar creation hypothesis is the so-called break point bar mechanism. The cross-shore bar position with this hypothesis scales as

$$
x_{b p}=\frac{\gamma H_{b}}{\beta}
$$

in which $x_{b p}$ is the cross-shore position of the bar, $H_{b}$ is the breaking wave height, and $\gamma$ is the ratio of wave height to the depth of breaking waves $(\mathrm{O}(1))$. With this model, a breaking wave height of approximately $10 \mathrm{~m}$ is necessary to give a cross-shore scale of $1000 \mathrm{~m}$. It is likely that both bar generation mechanisms are important due to the highenergy dissipative beaches in the study area, however, an understanding of the flow field and associated morphological feedback will be necessary to fully understand the observed bar properties.

Bar height can be scaled with the following empirical formulation derived from the tank studies used in the formulation of the cross-shore profile change model SBEACH (Larson and Kraus, 1989)

$$
h_{b a r}=128 H_{b}^{1.36} w^{-0.58}
$$

where $h_{b a r}$ is the bar height and $w$ is the fall speed parameter in $\mathrm{cm} / \mathrm{s}$. For a $4.0 \mathrm{~m}$ bar height (typical outer bar height for the Long Beach sub-cell) a fall speed of $0.6 \mathrm{~cm} / \mathrm{s}$ is necessary assuming the $10 \mathrm{~m}$ wave height given in (2). This fall speed is too slow for the typical grain size found in Long Beach, for a median grain size of $0.15 \mathrm{~mm} w$ should be closer to $1.5 \mathrm{~cm} / \mathrm{s}$. A final simple bar scaling parameter is the depth of water at the bar crest, also derived empirically from tank studies (Larson and Kraus, 1989)

$$
Z_{c}=0.66 H_{b}
$$

where $Z_{c}$ is the depth at the bar crest. For a $10 \mathrm{~m}$ wave height the bar crest given by (4) is $6.6 \mathrm{~m}$, a fairly reasonable value.

\section{TEMPORAL VARIABILITY}

Several of the cross-shore profiles were surveyed in both 1998 and 1999 revealing annual change in sand bar morphology along this Pacific Northwest coast for the first time. Figure 9 illustrates the variability of a profile in Ocean City, WA over a 15-month period. The well defined outer bar, $\mathrm{O}(2 \mathrm{~m})$ in height, evident in the April 1998 survey lowered by 
July as the crest moved onshore with deposition in the trough. An inner bar in $3 \mathrm{~m}$ water depth is evident during the July 1998 surveys. Even with the occurrence of a few minor storms in late September 1998, the outer bar continued to decrease in amplitude with movement onshore between July and October and the trough became only weakly defined. The outer bar is in virtually the same location in the July 1999 survey, however, the trough has deepened over a meter. The shoreline is fairly constant in all surveys and no appreciable change in profiles is seen beyond the 6-m depth.

Only a very few nearshore morphology data sets existed on this coast before the onset of this study. The work of Willard Bascom and associates in the 1940s has been welldocumented (Kraus et al., 1996) and compared with the modern data (Ruggiero et al., 1999). It has recently been found that the Corps of Engineers also surveyed nearshore bathymetry along Clatsop Plains and the Long Beach Peninsula during their 1958 survey. Preliminary analysis is revealing morphology change over the last 40 years (Figure 10). This fledgling time series of nearshore morphology is also being supplemented by timeexposure images developed from an aerial videography system developed to rapidly measure large-scale morphologic variability (Worley et al., 1997).

\section{DISCUSSION AND CONCLUSIONS}

This extensive nearshore bathymetric data set reveals strikingly different large-scale coastal behaviour among the four sub-cells of the Columbia River littoral cell. Nearshore morphologic signals along North Beach and Long Beach are large and three-dimensional while along Grayland Plains and Clatsop Plains bars are more linear and smaller in magnitude. These observations are surprising in that the incident deep-water wave climate is virtually identical along the entire region, suggesting that sediment supply, sediment characteristics, antecedent morphology, or flow patterns may dominate the wave signal in forcing these regional differences. At medium-scale, the Grayland nearshore surface showed a net loss for the year while the Long Beach nearshore surface showed no net change. The Long Beach site has a long-term trend of stability/accretion while the Grayland site is eroding. An observation with implications for shoreline change modeling is that the annual limit of measurable cross-shore profile change from 1998 to 1999 ranges from 6 to $11 \mathrm{~m}$ (NAVD 88).

The initial results of this study raise several intriguing questions.

1) What process(es) are responsible for $4-6 \mathrm{~m}$ high bars $1000 \mathrm{~m}$ from the shoreline?

2) Are these length and height scales unique to the Pacific Northwest? Unique to 1999 ?

3) Why is the Grayland nearshore virtually 1-dimensional?

4) How does variability in sand bar size, location, etc. affect shoreline change? At what time scales?

5) Do CRLC bars migrate offshore? 
6) What morphological feedback mechanisms are responsible for both the medium- and regional-scale variability observed in the data?

Investigation of these and other questions will be addressed through processes experiments, continued monitoring, and wave and morphology change modeling efforts as part of the SWCES.

\section{ACKNOWLEDGEMENTS}

As usual, an incredible field team was assembled in 1999 for the collection of this data set, many rounds of miniature golf and of course, we finally learned to surf.

\section{REFERENCES}

Côté, J.M., Holman, R.A., Stanley, J., Ruggiero, P., and Beach, R.A. in review. Development and accuracy of the coastal profiling system, submitted to Journal of Coastal Research.

Flood, R. this volume. Preliminary results of a multibeam bathymetry and backscatter survey, Southwest Washington Coastal Erosion Workshop Report 1999, U.S. Geological Survey Open-File Report.

Holman, R.A., and Sallenger, A.H. 1993. Sand bar generation: A discussion of the Duck experiment series, Journal of Coastal Research, SI 15, pp 76-92.

Kraus, N.C., Weigel, R.L., and Bascom, W.N. 1996. Beach profile surveys along the U.S. Pacific Coast 1945-1947, Proceedings of the 25th ICCE, ASCE, pp. 3020-3033.

Larson, M., and Kraus, N.C. 1989. SBEACH: Numerical model for simulating storminduced beach change, Technical Report CERC-89-9, 256 p.

Oltman-Shay, J., Smith, F., Secan, J., Ruggiero, P., Pruis, M., Petruvu, U., Kaminsky, G., Echert, D., Cookson, A., Côté, J., Boss, E., and Bussey, R. 1998. Infragravityfrequency-band waves and currents on a Washington coast beach, American Geophysical Union Fall Meeting.

Ruggiero, P., Côté, J., Kaminsky, G., and Gelfenbaum, G. 1999. Scales of variability along the Columbia River littoral cell, Proceedings of Coastal Sediments '99, ASCE, pp. 1692-1707.

Worley, C.R., Lippmann, T.C., Haines, J.W., and Sallenger, A.H. 1997. An aerial video system for rapidly measuring sand bar morphology. Coastal Dynamics '97, ASCE, pp. 346-354. 
Table 1. Environmental conditions during summer 1999 field campaign. Typically one day a week was a down day due to either inclement weather (often fog) or equipment maintenance.

\begin{tabular}{|c|c|c|c|c|c|c|c|c|c|c|c|c|c|}
\hline Week & Site & Time & \begin{tabular}{|l|} 
Profiles \\
\end{tabular} & \multicolumn{4}{|c|}{ Waves } & Wind & \multicolumn{2}{|c|}{ Temp } & & \multicolumn{2}{|c|}{ Buoy } \\
\hline & & & & $\begin{array}{c}\overline{\mathrm{HS}} \\
\mathrm{m}\end{array}$ & $\begin{array}{l}\text { Dir } \\
\text { deg }\end{array}$ & $\begin{array}{l}\text { Tp } \\
\text { sec }\end{array}$ & $\begin{array}{l}\text { Ta } \\
\text { sec }\end{array}$ & $\begin{array}{l}\text { Speed } \\
\mathrm{m} / \mathrm{sec}\end{array}$ & $\begin{array}{l}\text { Air } \\
{ }^{\circ} \mathrm{C}\end{array}$ & $\begin{array}{l}\text { Water } \\
{ }^{\circ} \mathrm{C}\end{array}$ & $\begin{array}{l}\mathrm{P} \\
\mathrm{mb}\end{array}$ & GH & CRB \\
\hline Week 1 & Ocean City & (.ocn) & & & & & & & & & & & \\
\hline & |7/15/99 & 14:00-18:10 & 11 & 1.86 & 297 & 9.1 & 7.0 & & & 10.6 & $\mid 1016.9$ & $\mathrm{X}$ & \\
\hline & 7/16/99 & $16: 05$ & 4 & 0.98 & 300 & 9.1 & 6.9 & & & 11.2 & 1013.3 & $\mathrm{X}$ & \\
\hline Week 2 & Ocean City & (.ocn) & & & & & & & & & & & \\
\hline & $\begin{array}{l}\text { 7/20/99 } \\
\text { Ocean Shore }\end{array}$ & $\begin{array}{l}15: 00 \\
\text { (.osh) }\end{array}$ & 13 & 1.08 & 300 & 7.7 & 5.8 & & & 11.9 & 1014.8 & $\mathrm{X}$ & \\
\hline & 7/21/99 & $7: 22-11: 20$ & 11 & 0.96 & 302 & 6.7 & 5.7 & & & 12 & 1015.5 & $x$ & \\
\hline & 7/21/99 & $17: 35$ & 6 & 0.71 & 303 & 6.3 & 5.4 & & & 12.8 & 1018.0 & $\mathrm{X}$ & \\
\hline & 7/22/99 & $7: 40-10: 30$ & 8 & 0.97 & 296 & 9.1 & 7.6 & & & 13.4 & 1020.4 & $X$ & \\
\hline Week 3 & Long Beach & (.lbp) & & & & & & & & & & & \\
\hline & 7/27/99 & $12: 36-18: 05$ & 14 & 1.03 & 324 & 7.7 & 5.7 & 4.6 & 12.3 & 14.2 & 1014.8 & & $X$ \\
\hline & 7/28/99 & $13: 50-16: 50$ & 11 & 1.14 & 355 & 8.3 & 5.5 & 4.3 & 11.8 & 13.6 & 1016.4 & & $x$ \\
\hline & 7/29/99 & $13: 20-17: 11$ & 13 & 0.95 & 337 & 8.3 & 6.6 & 1.3 & 12.6 & 14.2 & 1020.3 & & $\mathrm{X}$ \\
\hline Week 4 & Long Beach & (.lbp) & & & & & & & & & & & \\
\hline & 8/3/99 & $13: 40-19: 25$ & 9 & 0.83 & 130 & 6.3 & 6.8 & 0.1 & 14.1 & 14.8 & 1022.6 & & $x$ \\
\hline & 8/5/99 & $15: 35-19: 12$ & 8 & 1.05 & 347 & 11.1 & 5.4 & 4.2 & 14.4 & 15.3 & 1014.4 & & $\mathrm{X}$ \\
\hline & 8/6/99 & 9:00 & 6 & 0.93 & 353 & 5.9 & 4.8 & 3.5 & 14.9 & 15.6 & 1011.0 & & $x$ \\
\hline Week 5 & Clatsop Plain & (.clp) & & & & & & & & & & & \\
\hline & $8 / 10 / 99$ & $12: 15-15: 19$ & 11 & 1.36 & 332 & 5.6 & 4.9 & 7.6 & 14.1 & 14.8 & 1011.8 & & $x$ \\
\hline & $8 / 11 / 99$ & $12: 40-14: 54$ & 9 & 1.66 & 232 & 8.3 & 6.4 & 1.6 & 15.1 & 14.1 & 1013.7 & & $\mathrm{X}$ \\
\hline & $8 / 12 / 99$ & $12: 01-14: 31$ & 5 & 1.28 & 196 & 6.7 & 5.8 & 2.7 & 14.9 & 14.5 & 1019.5 & & $\mathrm{X}$ \\
\hline Week 6 & Clatsop Plain & (.clp) & & & & & & & & & & & \\
\hline & $8 / 17 / 99$ & $16: 30-19: 06$ & 7 & 0.98 & 344 & 6.7 & 5.5 & 4.6 & 14.8 & 15.7 & 1020.3 & & $X$ \\
\hline & 8/18/99 & 16:30-19:37 & 9 & 1.01 & 294 & 8.3 & 6.4 & 1.5 & 15.2 & 16.4 & 1015.8 & & $\mathrm{X}$ \\
\hline Week 7 & $\begin{array}{l}\text { Grayland } \\
\text { Plains }\end{array}$ & (.gld) & & & & & & & & & & & \\
\hline & 8/23/99 & 13:03-14:27 & 6 & 1.27 & 296 & 5.9 & 4.9 & & & 11.6 & 1011.4 & $x$ & \\
\hline & 8/24/99 & $10: 59-14: 21$ & 14 & 0.79 & 297 & 7.7 & 5.2 & & & 13.1 & 1014.2 & $X$ & \\
\hline & $8 / 25 / 99$ & $12: 10-15: 19$ & 10 & 1.72 & 267 & 6.3 & 5.3 & & & 14.3 & 1014.8 & $X$ & \\
\hline & $8 / 26 / 99$ & $12: 20-15: 53$ & 11 & 1.34 & 268 & 8.3 & 6.9 & & & 14.4 & 1016.3 & $X$ & \\
\hline & 8/27/99 & $13: 30-15: 37$ & 9 & 1.2 & 275 & 8.3 & 6.5 & & & 13.1 & 1010.3 & $x$ & \\
\hline Week 8 & $\begin{array}{l}\text { Grayland } \\
\text { Plains }\end{array}$ & (.gld) & & & & & & & & & & & \\
\hline & 8/30/99 & 15:05-18:11 & 10 & 1.94 & 300 & 6.7 & 6.0 & & & 11.8 & 1016.2 & $x$ & \\
\hline & $8 / 31 / 99$ & 15:27-18:04 & 7 & 1.69 & 278 & 8.3 & 6.0 & & & 12.8 & 1020.7 & $X$ & \\
\hline & 9/1/99 & 14:00-18:00 & 11 & 0.9 & 286 & 9.1 & 6.6 & & & 12.7 & & $\mathrm{X}$ & \\
\hline & 9/2/99 & $17: 00-17: 33$ & 2 & 1.54 & 279 & 9.1 & 7.7 & & & 12.8 & & $x$ & \\
\hline
\end{tabular}




\section{Columbia River Littoral Cell Monitoring Sites}

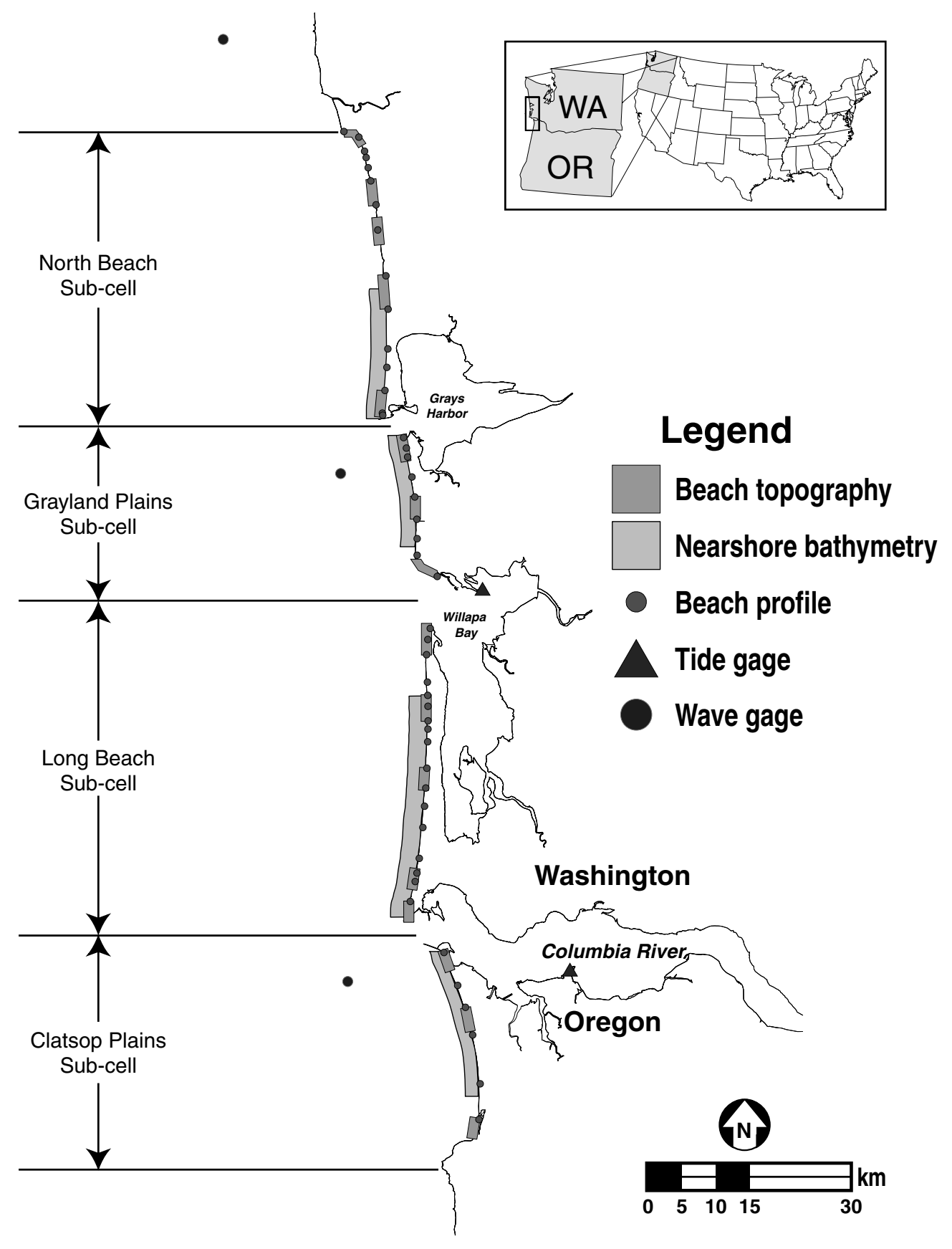

Figure 1. Beach morphology monitoring program nested sampling scheme including coverage of nearshore bathymetry surveys during the summers of 1998 and 1999. 

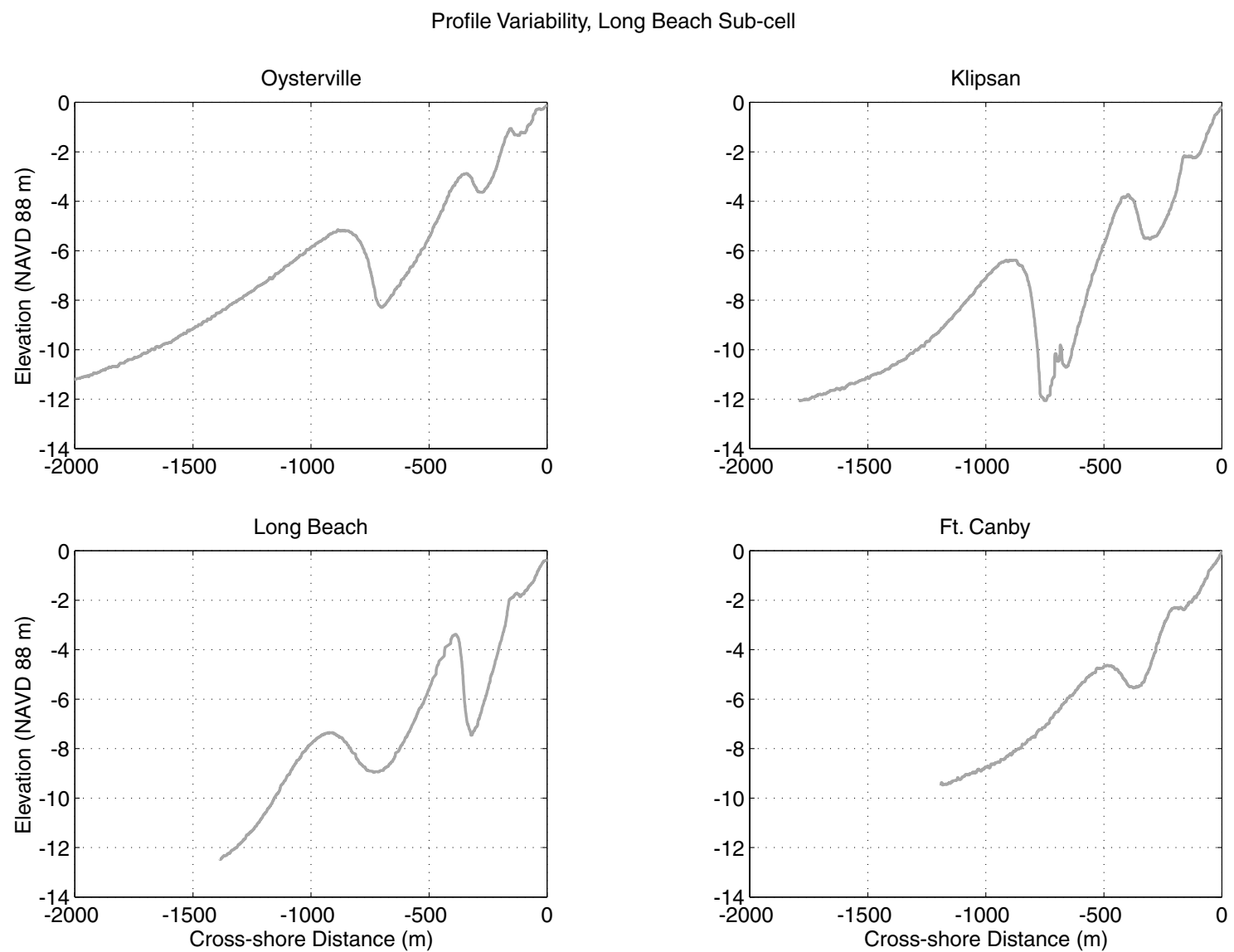

Figure 2. Four example cross-shore beach profiles from the Long Beach sub-cell. 


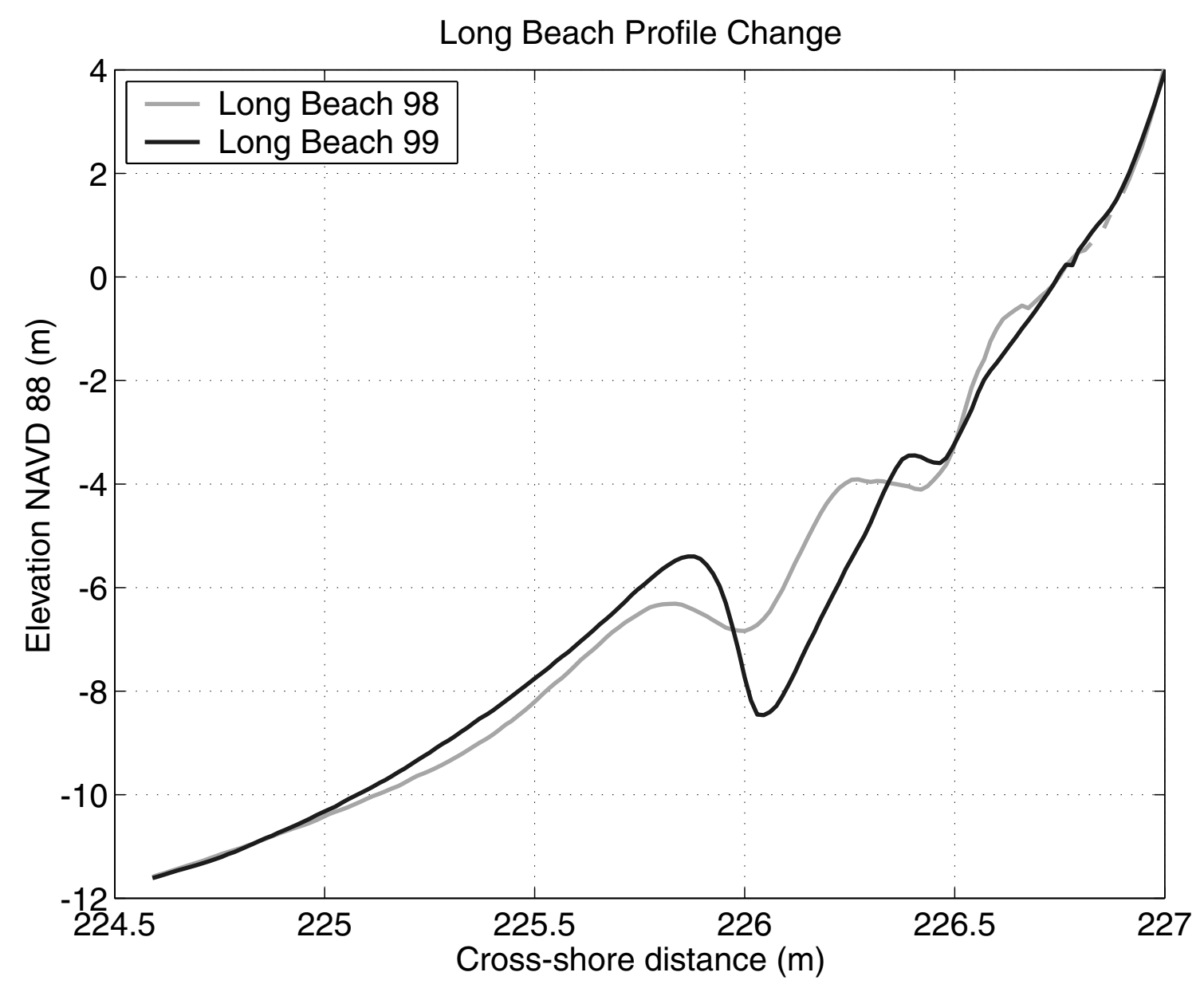

Figure 3. Comparison of alongshore averaged profiles near Oysterville for 1998 and 1999. 


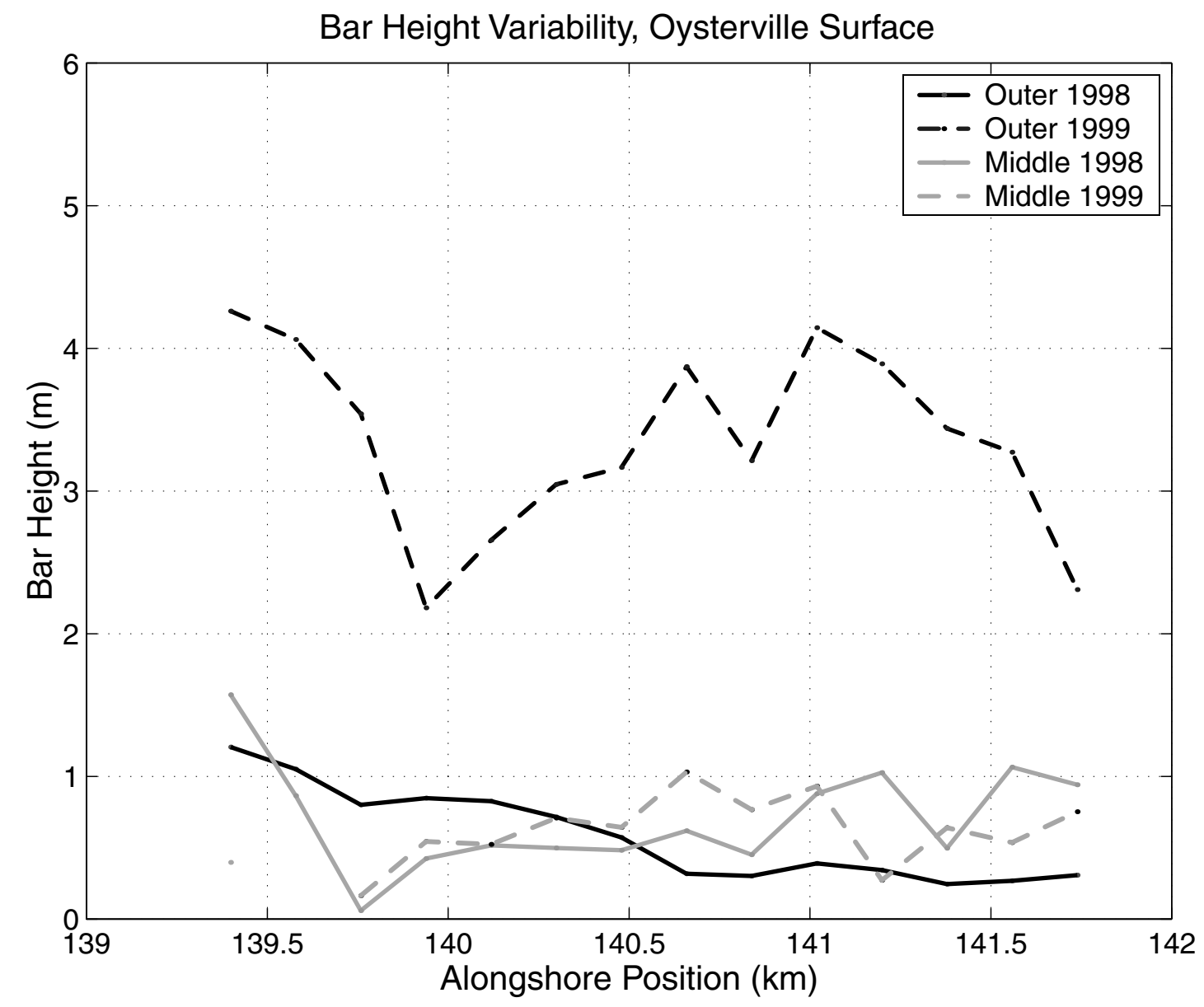

Figure 4. Medium-scale bar height variability in the Long Beach sub-cell. 


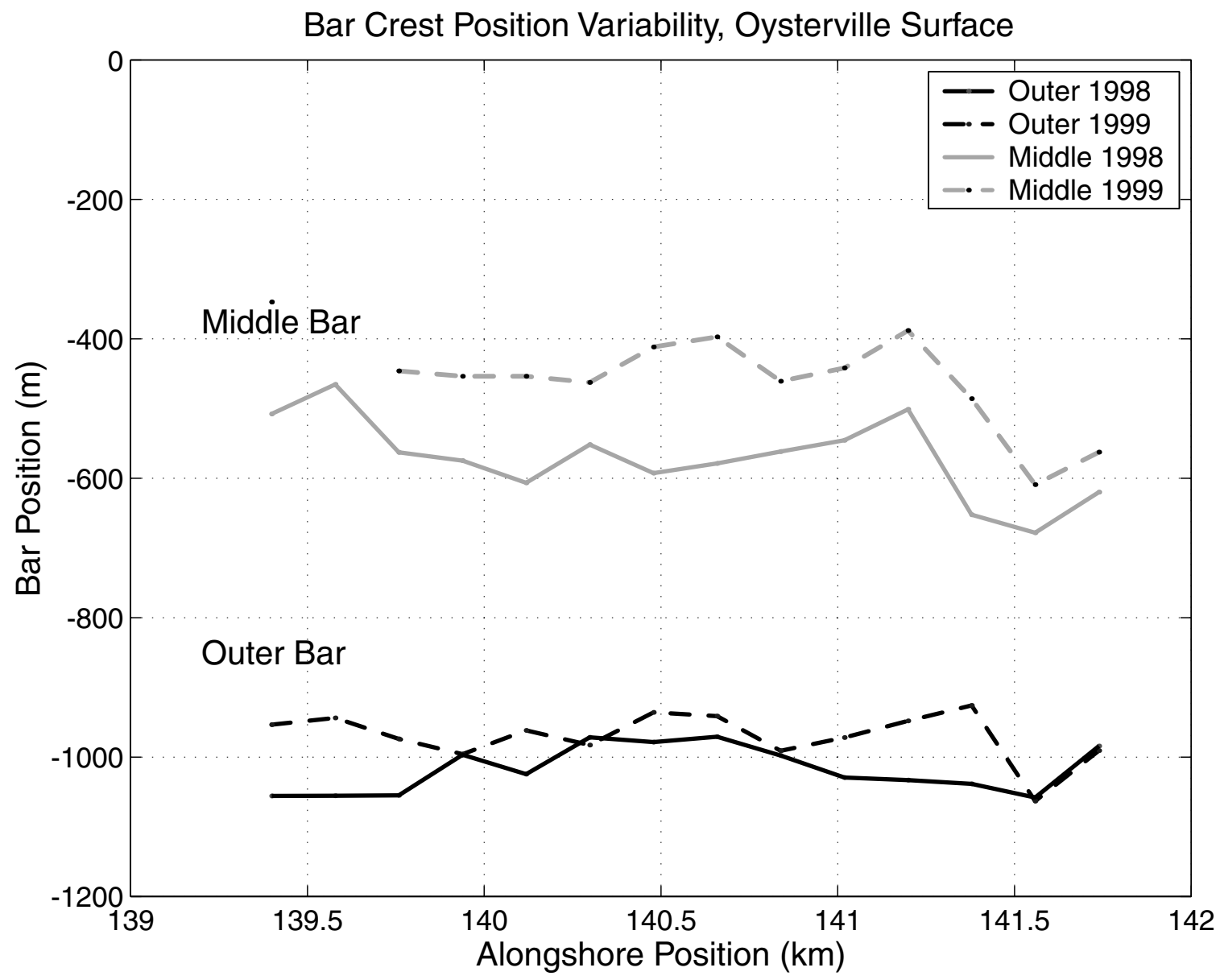

Figure 5. Medium-scale bar crest position variability in the Long Beach sub-cell. 


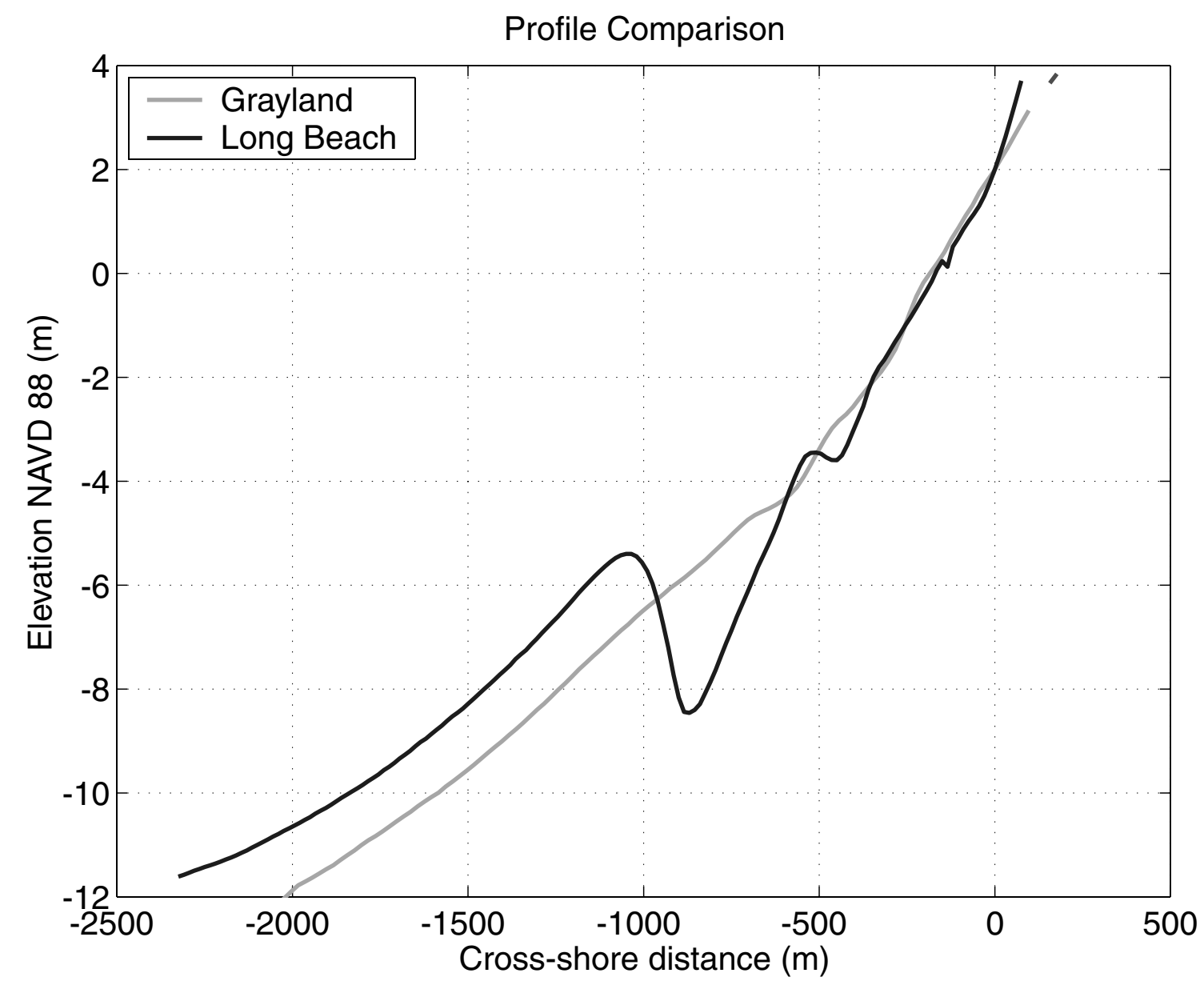

Figure 6. Medium-scale comparison between the alongshore averaged Long Beach profile and the alongshore averaged Grayland Plains profile. 

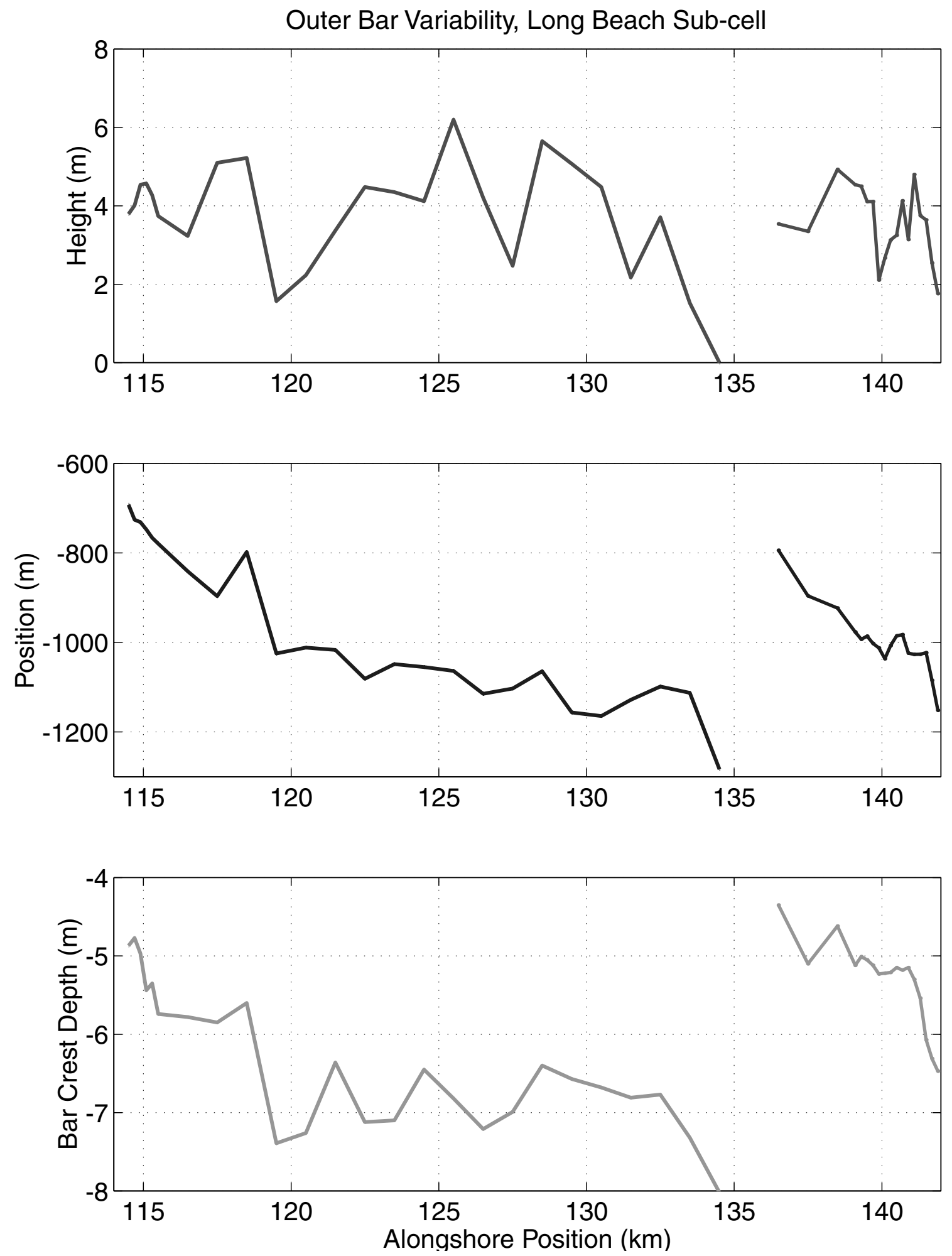

Figure 7. Large-scale statistics for the outer bar of the Long Beach sub-cell. 


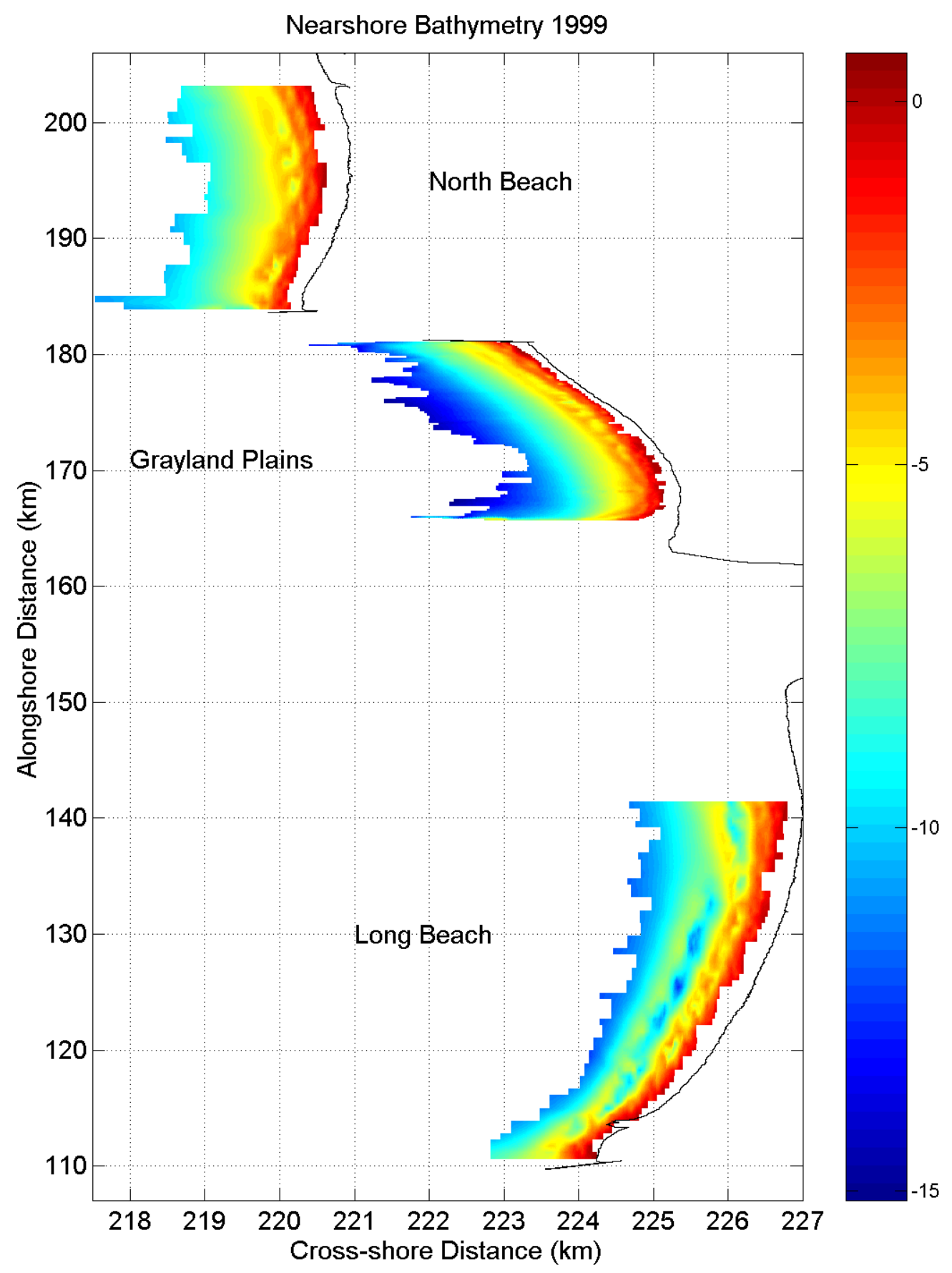

Figure 8. Large-scale coastal behaviour comparison between 3 sub-cells as measured in summer 1999. The colorbar indicates the water depths with cool colors (blues and greens) representing deeper water and warm colors (yellows and reds) representing shallower water. 


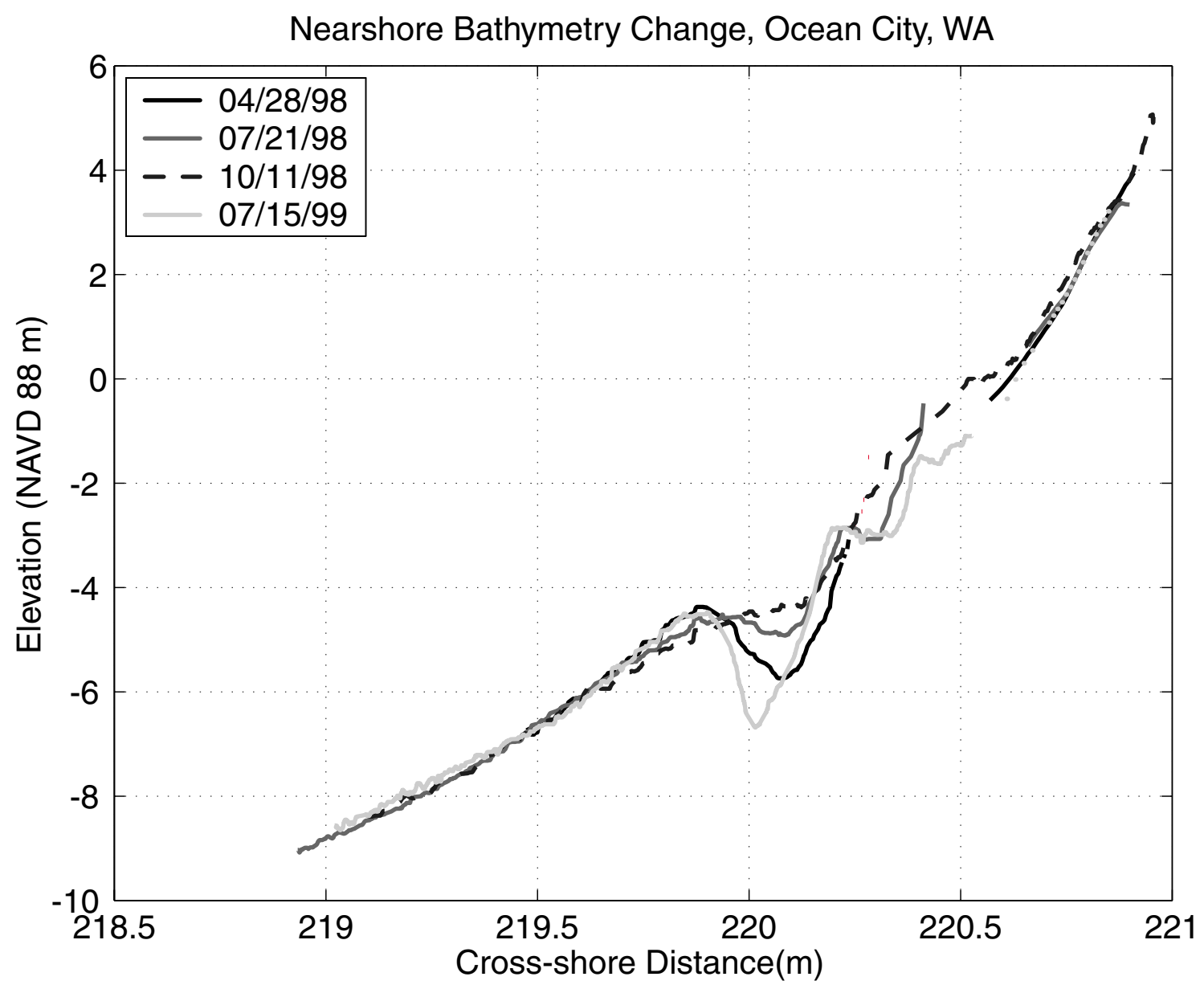

Figure 9. The seasonal comparison of beach profiles surveyed at Ocean City, WA during April, July, and October 1998 and July 1999 by the CPS and the CLAMMER. MLLW is approximately $-0.5 \mathrm{~m}$ NAVD 88. 


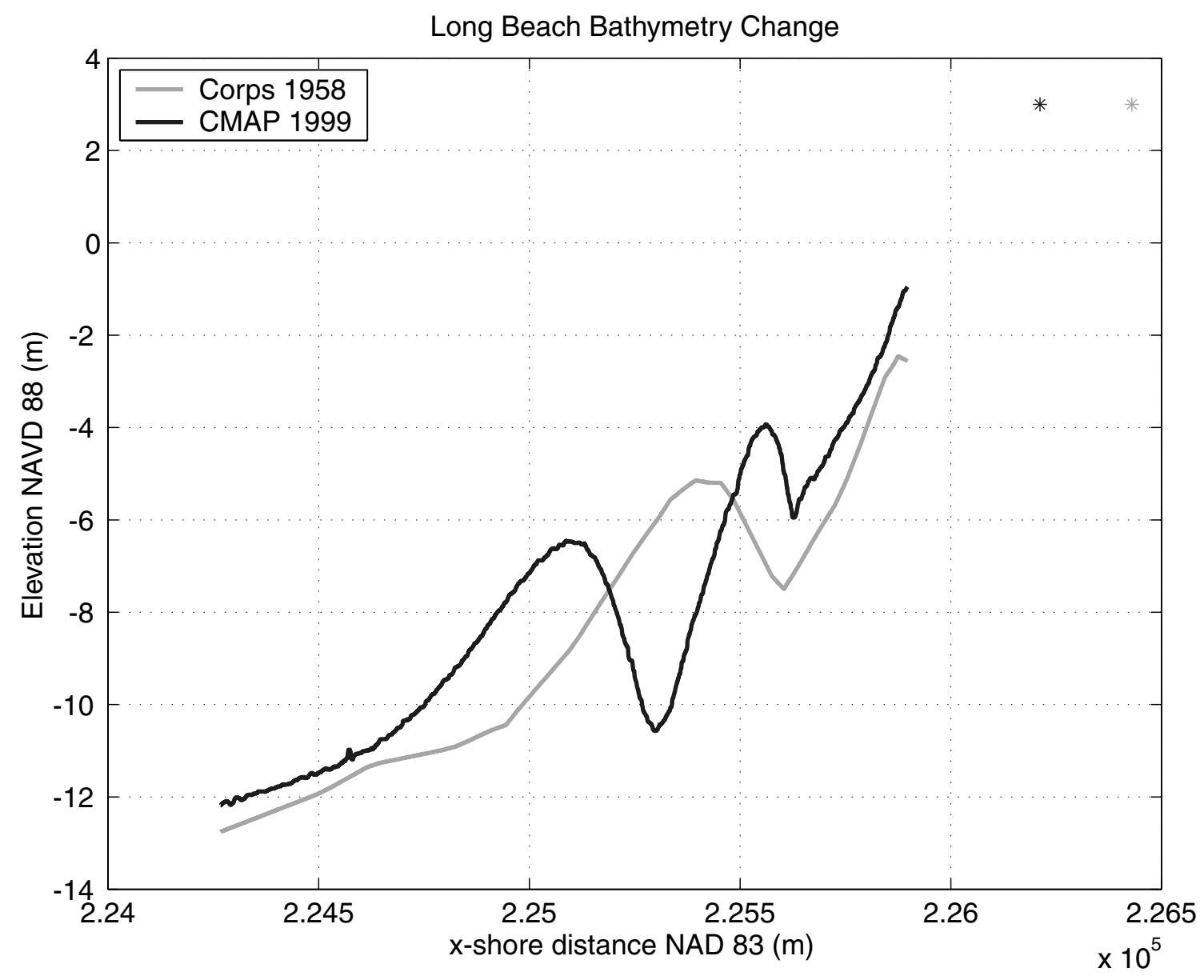

Figure 10. Comparison between Corps 1958 data and 1999 survey north of the city of Long Beach. The asterisks indicate the position of the shoreline in both 195x and 1995, plotted at the $3.0 \mathrm{~m}$ contour line. 


\section{LIST OF ATTENDEES}

\section{Dr. Jonathan Allan}

Oregon Department of Geology and Mineral Industries

Coastal Field Office

313 SW 2nd, Suite D

Newport, OR 97365

tel 541-574-6642

fax 541-265-5241

e-mail Jonathan.Allan@dogami.state.or.us

\section{Mr. Steven D. Babcock}

U.S. Army Corps of Engineers, Seattle District

Seattle District Planning Branch

P.O. Box 3755 E. Marginal Way S.

Seattle, WA 98124-3755

tel (206) 764-3651

fax (206) 764-4470

e-mail steven.d.babcock@usace.army.mil

\section{Ms. Diana Baker}

Portland State University

P.O. Box 751

Portland, OR 97202-0751

tel (503) 725-3375

fax (503) 725-3025

e-mail psu13437@odin.cc.pdx.edu

\section{Mr. Paul R. Beauchemin}

U.S. Geological Survey

12201 Sunrise Valley Drive, MS 112

Reston, VA 20192

tel (703) 648-6654

fe-mail pbeauche@usgs.gov

\section{Ms. Heather Bragg}

Portland State University

P.O. Box 751

Portland, OR 97202-0751

tel (503) 725-3375

fax (503) 725-3025 
Mr. Eric Braun

U.S. Army Corps of Engineers, Portland District

P.O. Box 2946

CENPP-PE-HY

Portland, OR 97208-2946

tel (503) 808-4348

fax (503) 808-4344

e-mail Eric.P.Braun@nwp01.usace.army.mil

Mr. Maarten C. Buijsman

Washington State Department of Ecology

Coastal Monitoring \& Analysis Program

P.O. Box 47600

Olympia, WA 98504-7600

tel (360) 407-7125

fax (360) 407-6902

e-mail mbui461@ecy.wa.gov

Dr. Michael D. Carr

U.S. Geological Survey

Coastal and Marine Geology Program

345 Middlefield Road, MS 999

Menlo Park, CA 94025

tel (415) 354-3184

fax (415) 354-3020

e-mail mdcarr@usgs.gov

Ms. Mary Cialone

USAE Engineer Research \& Development Center

Waterways Experiment Station

ERDC-HC-C

3909 Halls Ferry Rd.

Vicksburg, MS 39180

tel (601) 634-2139

e-mail Mary.A.Cialone@erdc.usace.army.mil

\section{Dr. Peter J. Cowell}

University of Sydney

School of Geosciences

Marine Studies Centre

Coastal Studies Unit

NSW 2006

tel 62-2-9351-2189

fax 62-2-9351-3644

e-mail P.Cowell@csu.usyd.edu.au 


\section{Ms. VeeAnn A. Cross}

U.S. Geological Survey

384 Quissett Campus Woods Hole Rd.

Woods Hole, MA 02543-1598

tel (508) 457-2251

fax (508) 457-2310

e-mail vatnipp@usgs.gov

\section{Mr. Richard C. Daniels}

Washington State Department of Ecology

Coastal Monitoring \& Analysis Program

P.O. Box 47600

Olympia, WA 98504-7600

tel (360) 407-6427

fax (360) 407-6902

e-mail rdan461@ecy.wa.gov

\section{Dr. Roger Flood}

State University of NY

Marine Sciences Research Center

Stony Brook, NY 11794-5000

tel (631) 632-6971

fax (631) 632-8820

e-mail rflood@notes.cc.sunysb.edu

\section{Mr. Jerry Franklin}

Washington Department of Ecology

Coastal Monitoring \& Analysis Program

P.O. Box 47600

Olympia, WA 98504-7600

tel (360) 407-7470

fax (360) 407-6902

e-mail jfra461@ecy.wa.gov

\section{Mr. Chuck Gale}

Pacific International Engineering

144 Railroad Avenue, Suite 310

Edmonds, WA 98020

tel (425) 744-7700

fax (425) 744-1400

e-mail chuckg@piengr.com 


\author{
Dr. Guy R. Gelfenbaum \\ U.S. Geological Survey \\ Coastal and Marine Geology Program \\ 345 Middlefield Road, MS 999 \\ Menlo Park, CA 94025 \\ tel (650) 329-5483 \\ fax (650) 329-5190 \\ e-mail ggelfenbaum@usgs.gov \\ Ms. Ann E. Gibbs \\ U.S. Geological Survey \\ Coastal and Marine Geology Program \\ 345 Middlefield Rd. MS 999 \\ Menlo Park, CA 94025 \\ tel (650) 329-5060 or (831) 459-3997 \\ fax (650) 329-5197 \\ e-mail agibbs@usgs.gov \\ Mr. Mike Hamer \\ U.S. Geological Survey \\ Coastal and Marine Geology Program \\ 345 Middlefield Road, MS 999 \\ Menlo Park, CA 94025 \\ tel (650) 329-5056 \\ fax (650) 329-5197 \\ e-mailmhamer@usgs.gov \\ Mr. Kurt Hanson \\ U.S. Geological Survey \\ Center for Coastal Geology \\ 600 4th Street S \\ St. Petersburg, FL 33701 \\ tel (727) 893-3100 ext 3084 \\ e-mail khanson1@usgs.gov \\ Ms. April Herb \\ Portland State University \\ Department of Geology \\ 17 Cramer Hall \\ 1721 SW Broadway \\ Portland, OR 97207-0751 \\ tel (503)725-3375 \\ fax (503)725-3025 \\ e-mail aherb@hotmail.com
}




\section{Dr. Peter Howd}

University of South Florida

Department of Marine Science

140 7th Avenue South

St. Petersburg, FL 33701-5016

tel (727) 553-1158

fax (727) 553-1189

e-mail phowd@marine.usf.edu

\section{Mr. Robert H. Huxford}

Washington State Department of Ecology

Coastal Monitoring \& Analysis Program

P.O. Box 47600

Olympia, WA 98504-7600

tel (360) 407-6780

fax (360) 407-6902

e-mail bhux461@ecy.wa.gov

Dr. David A. Jay

Oregon Graduate Institute

Center for Coastal and Land-Margin Research

P.O. Box 91000

Portland, OR 97291-1000

tel (503) 690-1372

fax (503) 690-1273

e-maildjay@ccalmr.ogi.edu

\section{Mr. George M. Kaminsky}

Washington State Department of Ecology

Coastal Monitoring \& Analysis Program

P.O. Box 47600

Olympia, WA 98504-7600

tel (360) 407-6797

fax (360) 407-6902

e-mail gkam461@ecy.wa.gov

\section{Ms. Laura A. Kerr}

U.S. Geological Survey

Coastal and Marine Geology Program

345 Middlefield Rd., MS 999

Menlo Park, CA 94025

tel (650) 329-5243

fax (650) 329-5190

e-mail 1kerr@usgs.gov 


\author{
Dr. Paul D. Komar \\ Oregon State University \\ College of Oceanic \& Atmospheric Sciences \\ Corvallis, OR 97331 \\ tel (503) 737-5210 \\ fax (503) 737-2064 \\ e-mail pkomar@oce.orst.edu
}

\title{
Ms. Emily F. Lindstrum
}

Washington State Department of Ecology

Coastal Monitoring \& Analysis Program

P.O. Box 47600

Olympia, WA 98504-7600

tel $360407-6436$

fax (360) 407-6902

e-mail emli461@ecy.wa.gov

\section{Ms. Diana C. McCandless}

Washington State Department of Ecology

Coastal Monitoring \& Analysis Program

P.O. Box 47600

Olympia, WA 98504-7600

tel (360) 407-6104

fax (360) 407-6902

e-mail dimc461@ecy.wa.gov

\section{Dr. Martin C. Miller}

Hart Crowser, Inc.

1910 Fairview Ave. East

Seattle, WA, 98102-3699

tel 206-324-9530

fax 206-328-5581

e-mailmcm@hartcrowser.com

\section{Dr. Laura Moore}

Woods Hole Oceanographic Institution

Dept. of Geology \& Geophysics

MS \#22

Woods Hole, MA 02543

tel (508) 289-3597

fax (508) 457-2187

e-mail lmoore@whoi.edu 


\section{Mr. Otto Moosburner}

U.S. Environmental Protection Agency

1200 6th Ave.

ECO-083

Seattle, WA 98101

tel 206-553-5198

fax 206-553-1775

e-mail moosburner.otto@epamail.epa.gov

\section{Mr. Rod Moritz}

U.S. Army Corps of Engineers, Portland District

P.O. Box 2946

CENPP-PE-HY

Portland, OR 97208-2946

tel (503) 808-4864

fax (503) 808-4875

e-mail hans.r.moritz@usace.army.mil

Dr. Robert A. Morton

U.S. Geological Survey

Center for Coastal Geology

600 Fourth Street South

St. Petersburg, FL 33701-4846

tel (727) 803-8747 x3080

fax (727) 803-2032

e-mail rmorton@cfcg.er.usgs.gov

\section{Mr. Eric E. Nelson}

U.S. Army Corps of Engineers, Seattle District

Design Branch

P.O. Box 3755

Seattle, WA 98124-3755

tel (206) 764-3557

fax (206) 764-6795

e-mail eric.e.nelson@nps.usace.army.mil

\section{Ms. Meg Palmsten}

U.S. Geological Survey

Center for Coastal Geology

6004 th St S.

St. Petersburg, FL 33701

tel (727) 803-8747 x3019

fax (727) 803-2032

e-mail palmsten@cfcg.er.usgs.gov 
Mr. Dave Percy

Portland State University

Department of Geology

P.O. Box 751

Portland, OR 97202-0751

tel (503) 725-3373

fax (503)725-3025

e-mail percyd@pdx.edu

Dr. Curt D. Peterson

Portland State University

Department of Geology

P.O. Box 751

Portland, OR 97202-0751

tel (503) 725-3375

fax (503) 725-3025

e-mail curt@ch1.ch.pdx.edu

Dr. Larry Phillips

U.S. Geological Survey

Coastal and Marine Geology Program

345 Middlefield Rd., MS 999

Menlo Park, CA 94025

tel (650) 329-5378

fax (650) 329-5197

e-mail lphillips@usgs.gov

\section{Dr. Jim B. Phipps}

Grays Harbor College

1620 Edward P. Smith Drive

Aberdeen, WA 98520-7599

tel (360) 538-4200

fax (360) 538-4299

e-mail jphipps@ghc.ctc.edu

\section{Mr. Dave Qualman}

Portland State University

P.O. Box 751

Portland, OR 97202-0751

tel (503) 725-3375

fax (503) 725-3025

e-mail psu08749@odin.cc.pdx.edu 


\section{Dr. Peter Ruggiero}

Washington State Department of Ecology

Coastal Monitoring \& Analysis Program

P.O. Box 47600

Olympia, WA 98504-7600

tel (360) 407-6230

fax (360) 407-6902

e-mail prug461@ecy.wa.gov

\section{Dr. Vladimir Shepsis}

Pacific International Engineering

144 Railroad Avenue

Suite 310

Edmonds, WA 98020

tel (425) 921-1703

fax (425) 744-1400

e-mail vladimir@piengr.com

Dr. Christopher R. Sherwood

U.S. Geological Survey

Coastal \& Marine Geology Program

345 Middlefield Road, MS 999

Menlo Park, CA 94025

tel (650) $329-5330$

fax (650) 3295190

e-mail csherwood@usgs.gov

\section{Mr. David Simpson}

Pacific International Engineering

144 Railroad Avenue

Suite 310

Edmonds, WA 98020

tel (425) 921-1705

fax (425) 744-1400

e-mail dsimpson@piengr.com

\section{Mr. Oscar Sorensen}

Portland State University

P.O. Box 751

Portland, OR 97202-0751

tel (503) 725-3375

fax (503) 725-3025 


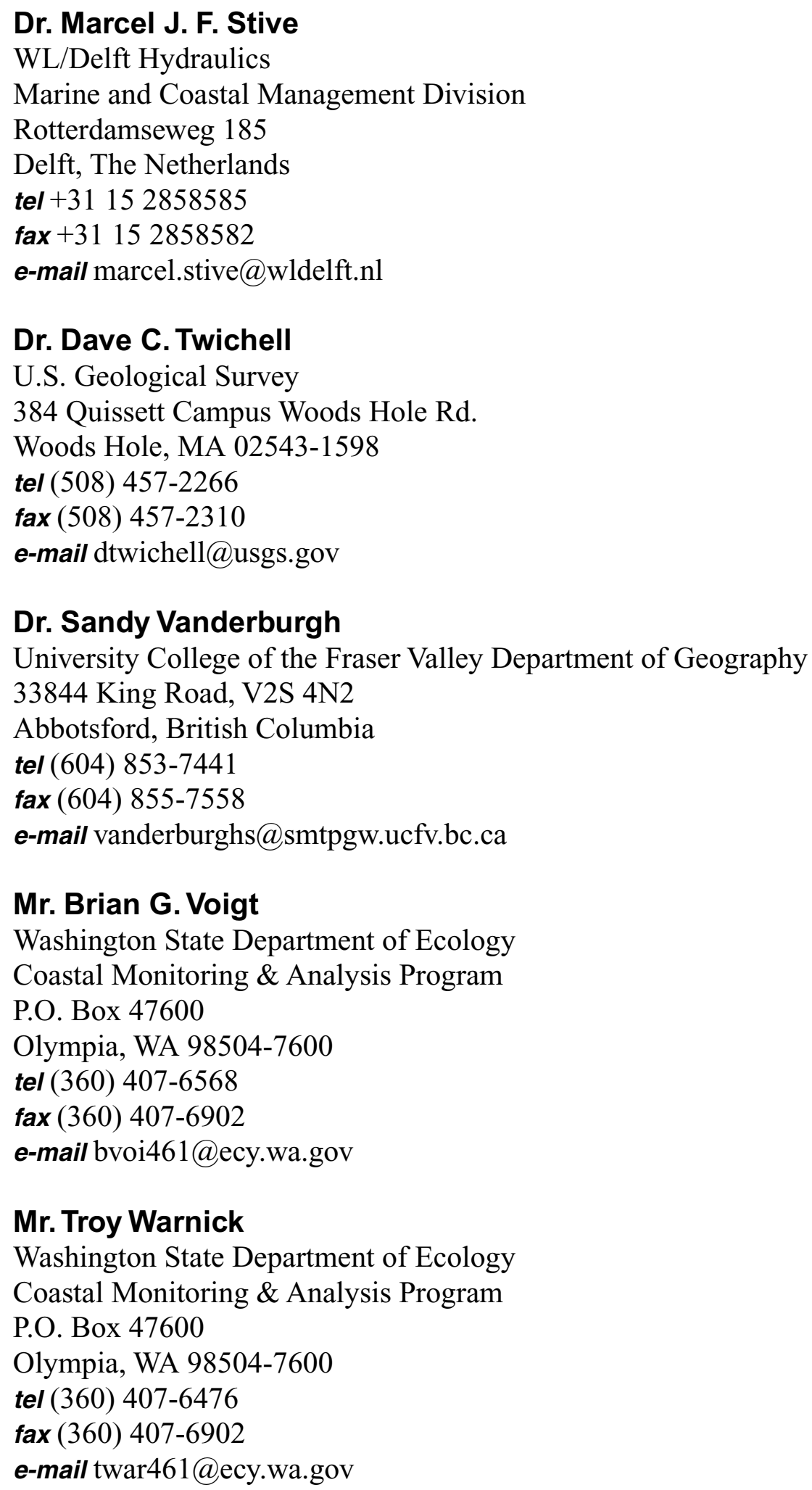




\section{GROUP PHOTOGRAPH}

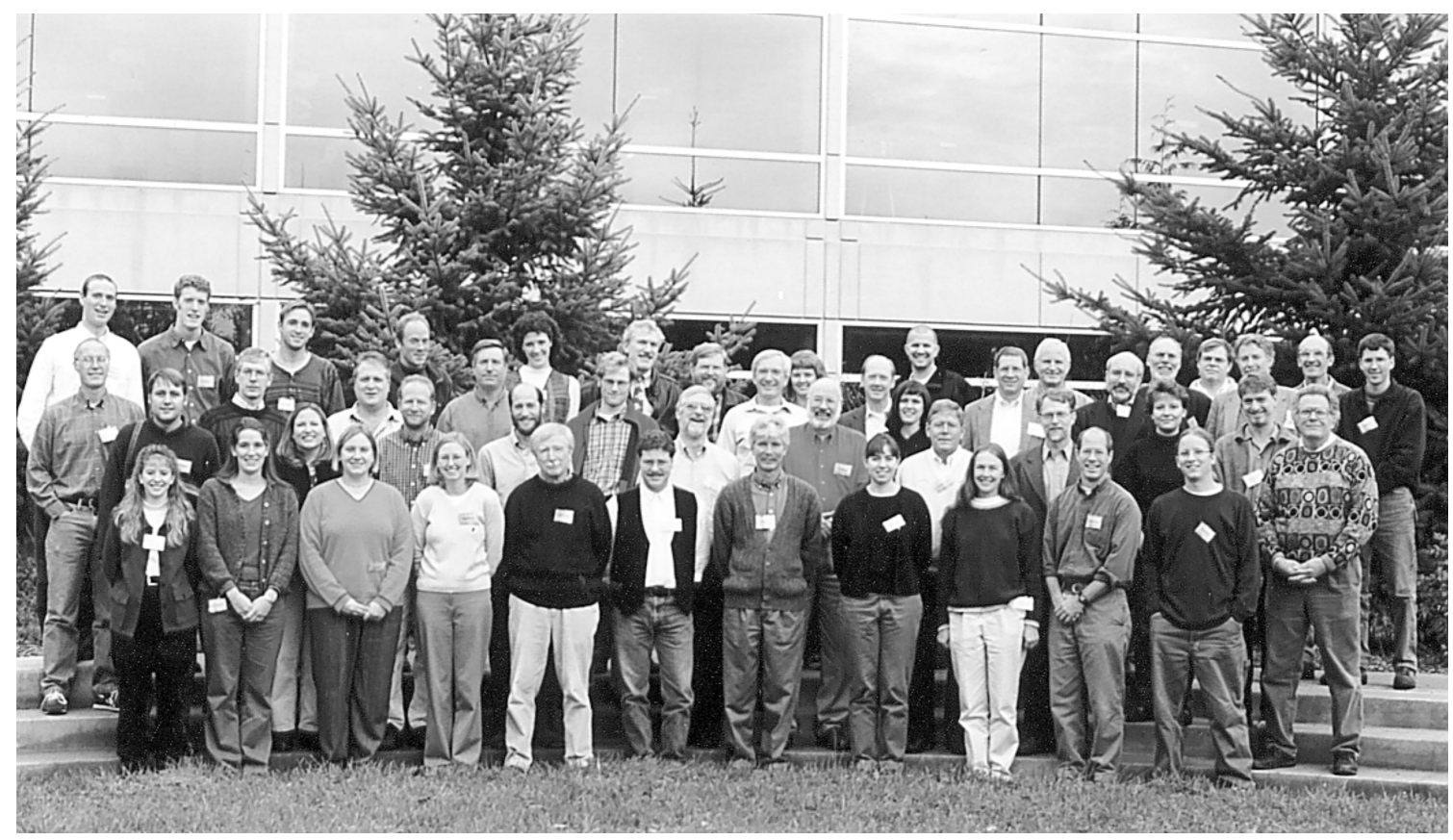

From left to right:

Front Row:

L. Moore, E. Lindstrum, L. Kerr, M. Palmsten, L. Phillips, J. Franklin, M. Hamer, A. Herb, V. Cross, C. Sherwood, B. Voigt.

Second Row: P. Ruggiero, A. Gibbs, G. Gelfenbaum, G. Kaminsky, B. Huxford, J. Phipps, P. Beauchemin, D. Jay, P. Komar.

Third Row: $\quad$ E. Braun, S. Babcock, S. Vanderburgh, C. Peterson, M. Buijsman, E. Nelson, M. Cialone, D. Baker, D. Percy.

Back Row: $\quad$ D. Qualman, K. Hanson, T. Warnick, R. Moritz, D. McCandless, M. Miller, R. Flood, H. Bragg, D. Simpson, O. Sorenson, B. Morton, O. Moosburner, M. Carr, M. Stive, P. Howd, P. Cowell, D. Twichell, J. Allan.

Not Pictured: $\quad$ V. Shepsis, C. Gale, R. Daniels. 